Sheila Fernandes Pimenta e Oliveira Vânia de Fátima Martino Genaro Alvarenga Fonseca Silvia Regina Viel (org.)

\title{
Práticas Pedagógicas em Discussão
}

Coleção Educação e Educandos
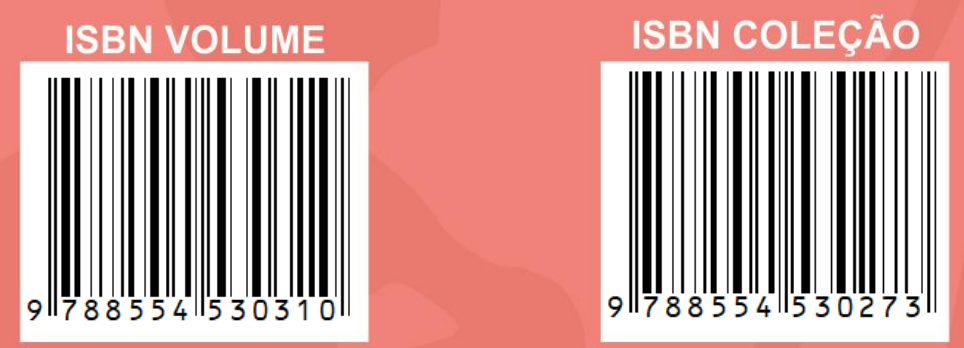

\author{
DOI \\ $10.29327 / 513116$
}





\section{PRÁTICAS PEDAGÓGICAS EM DISCUSSÃO}


Sheila Fernandes Pimenta e Oliveira

Vânia de Fátima Martino Genaro Alvarenga Fonseca

Silvia Regina Viel (org.)

\section{PRÁTICAS PEDAGÓGICAS EM DISCUSSÃO}

ISBN 978-85-5453-031-0

FRANCA

Uni-FACEF/UNESP

2019 


\section{Comissão Científica}

Alessandra David (Centro Universitário Moura Lacerda) Ana Lúcia Furquim Campos-Toscano (Uni-FACEF)

Célia Maria David (UNESP)

Fernando Silva Ribeiro (Universidade Estadual de Goiás)

Genaro Alvarenga Fonseca (UNESP)

Hilda Maria Gonçalves da Silva (UNESP)

Joana Correa Goulart (Universidade Estadual de Goiás)

Karina de Melo Conte (Centro Universitário Claretiano)

Karina Elizabeth Serrazes (Centro Universitário Claretiano)

Lucinda de Fátima Maria Coelho Rodrigues (Uni-FACEF)

Lucimary Bernabé Pedrosa de Andrade (FFCL)

Márcia Pereira da Silva (UNESP)

Maria Eloísa de Souza Ivan (Uni-FACEF)

Maria Madalena Graciloi (FFCL)

Maria Sílvia Pereira Rodrigues Alves Barbosa ((Uni-FACEF)

Pricila Bertanha (Centro Universitário Claretiano)

Sheila Fernandes Pimenta e Oliveira (Uni-FACEF)

Sílvia Regina Viel (Uni-FACEF)

Sílvio Carvalho Neto (Uni-FACEF)

Vânia de Fátima Martino (UNESP)

Tatiana Noronha de Souza (UNESP)

Welton Roberto Silva (Uni-FACEF)

\section{Conselho Editorial}

Ana Cláudia da Silva (UnB)

Antônio Carlos Petean (UFU)

Daniela Melaré Vieira Barros - Universidade Aberta / Portugal

Danilo Seithi Kato (UFTM)

Genaro Alvarenga Fonseca (UNESP)

Sheila Fernandes Pimenta e Oliveira ((Uni-FACEF)

Sílvio Carvalho Neto (Uni-FACEF)

Teise de Oliveira Guaranha Garcia - FFCLRP / USP

Vânia de Fátima Martino (UNESP) 
(C) 2019 dos autores

Direitos de publicação Uni-FACEF

www.unifacef.com.br

Coleção: Educação e Educandos, v. 5. 


Oliveira, Sheila Fernandes Pimenta e (Org.)
Práticas pedagógicas em discussão. / Sheila Fernandes Pimenta e
Oliveira; Vânia de Fátima Martino; Genaro Alvarenga Fonseca; Silvia
Regina Viel (Org.). - Franca: Uni-FACEF; Unesp/Franca; 2019. (Coleção:
Educação e educandos, v.5).
232p.; il.
ISBN Coleção: 978-85-5453-027-3
ISBN Volume: 978-85-5453-031-0
DOI 10.29327/513116
$\begin{array}{ll}\text { 1.Educação - Pesquisa. } & \text { 2. Educação e professores. 3.Práticas } \\ \text { I.T. } & \text { CDD } 370\end{array}$

TODOS OS DIREITOS RESERVADOS.

É proibida a reprodução total ou parcial, de qualquer forma ou por qualquer meio. A violação dos direitos de autor (lei no. 9.610/98) é crime estabelecido pelo artigo 184 do código Penal. Todo o conteúdo apresentado neste livro é de responsabilidade exclusiva de seus autores.

Editora Uni-FACEF Centro Universitário Municipal de Franca

Associada à ABEC - Associação Brasileira de Editores Científicos 


\section{PREFÁCIO}

Este livro surge como contribuição de um evento que se consolidou e que marca o calendário de educadores, pesquisadores e instituições comprometidas com a Educação na região de Franca/SP, desde 2007: o VII Simpósio de Educação e IV Encontro Internacional de Políticas Públicas em Educação. O Simpósio que ocorreu, nos dias 11 a 13 de setembro de 2019, teve como tema "Educação e Educandos: envolvimentos humanos, técnicos e sociais". O Evento, que nasce da parceria entre Uni-FACEF Centro Universitário Municipal de Franca e UNESP/Franca, contou com a participação de pesquisadores das mais variadas áreas. Em um conjunto de nove volumes temáticos, aqui o foco é a prática pedagógica.

Pensar as práticas pedagógicas, num contexto dinâmico e pluricultural, em que devem ser levadas em consideração várias questões como a ética, a diversidade e a inclusão, não é tarefa simples, para os profissionais e pesquisadores de hoje, que estão envolvidos nesta reflexão. Porém, são variadas e cada vez mais criativas as práticas inseridas nas salas de aula.

Lançando mão de ferramentas que antes pareciam não ter vínculo com a aprendizagem de conteúdos escolares como o cinema, ambientes virtuais, música, poesia, brinquedos, e mesmo o turismo, diversas discussões têm transformado as práticas de sala de aula das mais diversas disciplinas. Um profissional que conta com experiências, conhecimentos, capacidades e habilidades, para atuar de forma diferente da que aprendeu e para superar os desafios de uma educação global e tecnológica.

Outros olhares também têm sido lançados para as relações estabelecidas dentro da classe e discussões sobre a afetividade e aprendizagem significativa estão rendendo diversas reflexões e outros fazeres pedagógicos.

Extrapolar as disciplinas, sair da zona de conforto e buscar novas saídas para os entraves da aprendizagem, são alguns dos movimentos dos trabalhos apresentados nesta obra, que também ponderam os resultados das práticas tradicionais e do que se consideram boas práticas.

Nosso convite é que, ao ler este livro, que foi construído com muito apreço, todos aqueles que pensem ou se relacionem com as práticas pedagógicas, 
de alguma forma, possam se sentir instigados a lançar novos olhares e produzir conhecimento sobre as modernas possibilidades.

Boa leitura!

Profa. Dra. Silvia Regina Viel

Chefe de Departamento e Docente do Curso de Matemática Uni-FACEF Centro Universitário Municipal de Franca 


\section{SUMÁRIO}

A CONSTRUÇÃO DA NARRATIVAS E REPRESENTAÇÕES DE MARTINHO LUTERO: Práticas do Ensino de História e possibilidades na formação de alunos enquanto sujeitos históricos

A MÚSICA COMO FERRAMENTA DOS PROCESSOS DE ENSINOAPRENDIZAGEM

A RELEVÂNCIA DA BRINCADEIRA SIMBÓLICA NAS PRÁTICAS PEDAGÓGICAS VOLTADAS ÀS CRIANÇAS DE 6 ANOS DE IDADE...

AS POSSIBILIDADES DOS PROJETOS EDUCOMUNICATIVOS NO ENSINO FUNAMENTAL DIANTE DAS PRÁTICAS PEDAGÓGICAS

BRINQUEDOTECA UNIVERSITÁRIA E AS POSSIBILIDADES NA FORMAÇÃO DISCENTE CURSO DE PEDAGOGIA …................................. 62

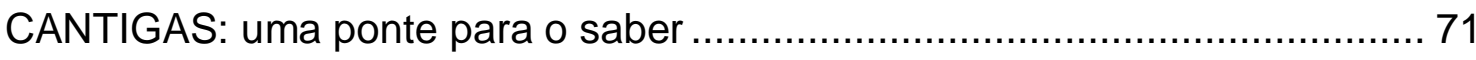

DE TUDO, E COM TAL ZELO: um passeio pela poética de Vinícius de Moraes

EDUCAÇÃO E ACOLHIMENTO: UTILIZANDO A EDUCAÇÃO AFETIVA COMO FORMA DE TRANSFORMAÇÃO SOCIAL ….................................... 98

EDUCAÇÃO SOCIAL: Um olhar diferente.

REFLEXÕES SOBRE AMBIENTES VIRTUAIS DE APRENDIZAGEM E CONVERGÊNCIA DIGITAL NA EDUCAÇÃO A DISTÂNCIA.

MÍDIAS NA EDUCAÇÃO SEXUAL: DOS SABERES AOS HORIZONTES DA PRÁTICA PEDAGÓGICA NA PERSPECTIVA DO CURSO DE EXTENSÃO EM FRANCA-SP.

NOVOS OLHARES PARA AS PRÁTICAS PEDAGÓGICAS DIANTE DOS PROJETOS DE TRABALHO

O GÊNERO LÍRICO DE MARIO QUINTANA EM COLÓQUIO COM O RITMO MUSICAL E A ARTE DO MURALISTA KOBRA NUMA SEQUÊNCIA DIDÁTICA INTERDISCIPLINAR

OS PRINCÍPIOS DA EDUCOMUNICAÇÃO: DIÁLOGANDO ENTRE COMUNICAÇÃO E EDUCAÇÃO

SEUS FILHOS NÃO PODEM APRENDER IGUAL A VOCÊ: Como a psicologia científica quebra mitos da aprendizagem e nos ajuda a moldar a escola do futuro

TURISMO PEDAGÓGICO: Uma ferramenta para o desenvolvimento.

ÍNDICE 232 


\title{
A CONSTRUÇÃO DA NARRATIVAS E REPRESENTAÇÕES DE MARTINHO LUTERO: Práticas do Ensino de História e possibilidades na formação de alunos enquanto sujeitos históricos
}

\author{
VICENTE, Lucas Guimarães \\ Mestre - UNESP \\ CAROTA, Filipe Pimenta \\ Mestre - UNESP
}

\section{INTRODUÇÃO E PERCURSO METODOLÓGICO}

A metodologia empregada na construção desse trabalho tem, portanto, origem na revisão bibliográfica dos textos que apresentam Lutero e na análise do material didático produzido por três editoras diferentes: Poliedro, FTD, Saraiva.

\section{AS NARRATIVAS E REPRESENTAÇÕES DE MARTINHO LUTERO NA HISTORIOGRAFIA ACADÊMICA}

A partir do texto de Batista de Oliveira (2013) entende-se que a historiografia acadêmica corresponde àquela produzida em universidades e com a finalidade de pesquisa científica. Para tanto, utiliza problemáticas sofisticadas, fontes diversas e metodologias especificas com a finalidade de narrar o processo histórico em suas variadas dimensões. Nesse trabalho, os autores dessa categoria são Perry Marvin (2002), Thomas A. Brady Jr (1979), Berman (2003), Braudel (1978), Guizbuirg (2007), Febvre (2012), Kosellecek (2006), Chartier (2002), Le Goff (1990).

Inicialmente, ao analisar a obra de Berman (2003), percebe-se que o autor considera o avanço do protestantismo na Alemanha e Inglaterra fundamentais para construção da tradição jurídica ocidental moderna permitindo a compressão dos fenômenos de rupturas ou permanências das estruturas do cotidiano na história. Essa análise retoma a perspectiva da História Cultural, que Chartier define como: "Compreender com as apropriações concretas e as invenções dos leitores [...] dos efeitos de sentido para os quais apontam as próprias obras, dos usos e significados". (CHARTIER, 2010, p. 43)

Sendo Lutero um influenciador na tradição jurídica, percebe-se a apropriação do pensamento luterano na Confissão Magdeburg (1550 - 1551), onde é possível observar as suas representações na construção do direito moderno alemão. Já que o ofício do historiador segundo Braudel é seguir as rupturas na temporalidade e entender as particularidades desses fenômenos:

[...] O que interessa apaixonadamente um historiador é o entrecruzamento desses movimentos, sua interação e seus pontos se registrar em relação ao tempo uniforme dos historiadores, medida geral de todos esses fenômenos, 
e não ao tempo social multiforme, medida particular a cada um desses fenômenos. (BRAUDEL, 1978, p.73)

Perry Marvin (2002) situou o pensamento luterano no rompimento das estruturas medievais-católicas vigentes, exclusivamente a dimensão social: fim da hierarquização social e religiosa, para um igualismo e individualismo social. Nesse sentido, é preciso sair do reducionismo, que delimitam o espaço da reforma de Lutero apenas no campo sócio religioso, sem buscar retratar suas implicações político-culturais1. Essa dimensão concebe Lutero como homo-religious, tratando-o como uma ficção, já que percebem a religião como uma provedora da ideologia necessária para que forças sociais amadureçam e se tornem independentes da religião em si2. Por isso, ao repensar Lutero na construção da identidade o historiador Thomas A. Brady Jr., autoridade no campo de estudos da Reforma, afirma que "talvez o tempo para uma nova abordagem tenha chegado [...] a Reforma como uma adaptação do cristianismo à evolução social da Europa"3. Apropriações e ressignificações do pensamento político de Lutero implicaram na construção da tradição jurídica ocidental moderna. Haja vista, que Berman (2003) considera as repercussões do pensamento luterano, tanto na Alemanha como na Inglaterra, fundamentais na construção do Estado moderno4.

Lindeberg (20017) defende que o legado da reforma proporcionou os fundamentos para racionalização da sociedade, como para construção moderna da liberdade, igualdade e democracia. Ao longo dos anos, para distanciar esses valores da ética luterana, a marginalização da reforma e dos fundamentos judaicos - cristãos na historiografia política se deu como fruto de dois aspectos do estudo histórico: o primeiro referente a historiografia marxista que aloca o fenômeno social como primordial, no qual a religiosidade apenas é instrumento discursivo na dialética de classes. O segundo, a pós-modernidade apresentada sob uma realidade desfragmentada, sendo tratar 0 todo, tornando tudo uma ilusão5. A desfragmentação da realidade aponta uma contemporaneidade alienada no "agora" e "presente", já que o contínuo da historicidade não existe é uma ilusão do desejo teleológico da história, entretanto, os valores da ótica luterana fundamentam o Estado Moderno.

Lutero foi considerado também um religioso reprimido que produziu uma filosofia, confusa e incerta, próprio de alemães, como os casos Hegel e Schelling6. O reformador foi analisado com uma filosofia rasa, resultado de sua posição social inferior, que não conseguiu compreender a vida contemplativa do

\footnotetext{
${ }^{1}$ PERRY, Marvin. Civilização Ocidental: uma história concisa. 3 ed. São Paulo: Martins Fontes, 2002, p.244246.

${ }^{2}$ LINDEBERG, Carter. História da Reforma. Rio de Janeiro: Thomas Nelson Brasil. 2017. p.53.

3 BRADY JR, Thomas A. The Social History of the Reformation 1979, p. 43 . Apud idem, p. 49.

${ }^{4}$ BERMAN, Harold J. Law and Revolution, II: the impact of the protestant reformations on the western legal tradition. Cambridge: Harvard University Press, 2003. p. 1-4.

${ }^{5}$ GIDDENS, Anthony. As Consequências da Modernidade. São Paulo; UNESP, 1991. p. 56

6 MORENO, R. Introdução in LUTERO, Martinho. Da liberdade do Cristão (1520): Prefácio à Bíblia. Edição bilíngue São Paulo, UNESP, 1998, p.15. Apud NIETZSCHE, Friedrich W. Além do Bem e do Mal. Milano; Mondadori, 1981, p.283. (uso da edição italiana).
} 
catolicismo. Desta forma, situava-o falhando no papel de monge, sendo incapaz de compreender e cumprir seu voto de santidade, voltando-se aos piores sentimentos: o vingativo. Movido por esse sentimento, se apresentava pronto para destruir a vida contemplativa e ainda o igualava a trabalhos inferiores como de artesões e camponeses.

Já Lucien Febvre (2012), implica a atuação de Lutero no contexto histórico, própria de um alemão, frio, calculista e idealista, seguindo a ideia apresentada por Nietzsche de que as ações de Lutero não se guiavam apenas por processos de ordem doutrinal, mas também moral e psicológica. Desta forma, o reformador não tinha pudor em expor as contradições do sistema católico ou imperial, e ao mesmo tempo, divulgar seus ideais. Lutero é definido por Febvre (2012) como um pequeno burguês de ideias curtas.

Entretanto, o pensamento luterano ponderava em situar todo o discurso de liberdade, que incialmente era a voz de um sentimento coletivo popular na construção do pensamento alemão. O peso da análise de Febvre a construção da identidade de Lutero é fundamental por considerar o luteranismo, uma barreira a revolução popular, situando novamente a análise ao quesito teleológico. Por isso afirma:

Não, Lutero não tratou de renegar seu passado. Forçado a ceder pela investida convergente dos homens e dos fatos, disfarçava para si mesmo a extensão de seu recuo agindo firme, bruscamente, contra os adversários que o pressionavam demais. (FEBVRE, 2012, p. 287)

Para Lutero, ainda que os homens eram vistos como iguais, o "Reino da Criação" - dos homens - era organizado em três estados fundamentais: esfera dos sacerdotes, família e governo civil. Os três são apresentados com a mesma importância e medida social, só se diferenciando em sua função. $O$ primeiro englobava o propósito de redimir a natureza caída pregando e administrando sacramentos. O segundo envolvia as famílias e os ofícios fundamentais para criar bons servos de Deus e cidadãos, como sustentar o desenvolvimento do reino. $O$ último refere-se ao estado temporal das autoridades governantes que deve usar a lei e a espada para garantir a ordem da Providência.

A segunda representação do pensamento político de Lutero é ainda a continuidade da teoria dos "Dois Reinos", que fundamenta a esfera do Estado Laico. Essa ideia defendia a extinção integral da jurisdição eclesiástica, tanto para criar normas, como para julgar questões e conflitos. Desta forma, esvaziando o poder eclesiástico, transportava-o para o poder secular. Assim, as leis ficam no cuidado dos principados alemães, regulando as matérias que estavam sobre o controle do poder eclesiástico, como as relações de família, casamentos, fundamentos morais, educação pública infantil. A ênfase recaia sobre a unidade do corpo jurídico, dividindo-o em público e privado, e subdividindo em propriedade e obrigações, modelo que seria base no mundo ocidental. 
Para Lutero a lei tinha três finalidades: a primeira era promoção da justiça cívica, com finalidade moral, ligada ao terceiro estado, para assim promover a civilidade e preservar a ordem da criação de Deus. A segunda, a lei seria para acusar e condenar o indivíduo, conduzindo para sua tarefa específica "consiste em reprovar o pecado e conduzir ao conhecimento do que seja o pecado".7 Por último, instruir e educar o procedimento social guiando as pessoas para o bem comum8.

Esta perspectiva conduz a três mudanças conjuntas no pensamento político moderno, a ideia de liberdade, igualdade e de comunidade política. Desta forma, o luteranismo fortalece a construção do estado-nação alemão, tendo como referência autonomia da localidade. A abordagem de Lutero aos 27 pontos de aconselhamento a nobreza alemã, desde práticas da igreja à administração das escolas e universidades, se encontra relacionada às práticas empresariais e comerciais. 9

As consequências deste caminho apontado por ele serão fundamentais na cisão com o império Papal e católico, a construção de estruturas morais e religiosas próprias, seja de Calvino e Zwingli nos países baixos, ou de Hooker na Inglaterra. Este especificamente, sistematizou a Igreja Anglicana no governo de Elizabeth I, apropriando-se da convicção reformada, que promove uma teoria do direito civil e eclesiástico apoiado na razão e na lei natural, influente na vida de futuros escritores políticos, como John Locke (1632-1704)10.

Portanto, ao observamos a importância das representações do pensamento político de Lutero e sua apropriação na visão reformada para construção do pensamento, situando-o como umas das matrizes para construção do mundo ocidental, é possível compreende-lo além dos pensadores clássicos e do empirismo histórico. Devido a isso, tanto Berman como Lindberg, consideram Lutero fundamental para a construção da tradição jurídica ocidental, permitido a referência para matérias como laicidade, liberdade, democracia, igualdade, nacionalidade e governo.

\section{AS NARRATIVAS E REPRESENTAÇÕES DE MARTINHO LUTERO NA HISTORIOGRAFIA DIDÁTICA}

$\mathrm{Na}$ historiografia didática, a ideia de fato histórico é apresentada como elemento da construção da identidade e formação da consciência histórica. Esse objetivo pode ser encontrando entre os conteúdos didáticos propostos nos Parâmetros Curriculares Nacionais e no texto da nova Base Nacional Comum Curricular. No processo de construção didática para o Ensino de História, houve um tempo em que o objetivo dessa disciplina foi atrelado a formação moral, instrucionista, cívica e patriótica, como na sua substituição por Estudos Sociais.

\footnotetext{
7 Idem.

8 Idem, p. 102-103.

${ }^{9}$ Na obra A Nobreza Cristã da Nação Alemã" (1520).

10 LINDEBERG, op. cit. p. 489.
} 
Sobre esse assunto é possível verificar a Reforma Universitária realizada em 1968 e a construção da Lei de Diretrizes e Bases 5692/71.

Nesse campo do saber, o texto didático se torna condicionado aos aspectos normativos da legislação, diretrizes e configuração da instituição escolar. Em relação a configuração escolar, Geane Kantovitz (2014) analisou a construção histórica na rede Salesiana e as contribuições de autores da historiografia acadêmica.

Kosellecek considera a história social em uma relação entre tempo e conceitos e com isto apresentamos a tese de que a experiência e a expectativa são duas categorias adequadas para tematizar o tempo histórico por entrecruzar passado e futuro. As categorias são adequadas para tentar descobrir o tempo histórico também no campo da investigação empírica, pois enriquecidas em seu conteúdo, dirigem as unidades concretas de ação na execução do movimento social e político11.

Ao observamos os livros didáticos com uma abordagem voltada a "Nova História Crítica", de Mário Schmidt, fundamentado no presente, desejoso em libertar os alunos de uma consciência burguesa preparando-os para uma luta de classe. Tendo como referência a obra do pensamento luterano, matérias jornalísticas situam o luteranismo como a origem do antissemitismo alemão, qual dará forma ao nazista12. Vincular uma obra destemperada de Lutero aos judeus ao movimento do século XX que tem como base a raça e o cientificismo do darwinismo social, demonstra a urgência de realmente contextualizar o papel da reforma luterana no pensamento político moderno.

Modelo seguido também pelos livros didáticos da Poliedro13 e FTD14, demonstrando o processo apenas como um caráter de ascensão da nobreza alemã, em busca por terra da igreja católica e maior autonomia, "Por outro lado, além do apoio da nobreza por razão políticas, as ideias de Lutero [...]"15.

E ainda, colocam no centro do quadro histórico, conflito entre camponeses e nobres16, deixando de lado todo papel educacional, político e social. E assim reafirmar, caráter de choque de classe, como revolucionário da história17,

\footnotetext{
${ }^{11}$ KOSELECK, R. Futuro do Passado: Contribuição à semântica dos tempos históricos. São Paulo; Contraponto, 2006, p.143. 12 EICHENBERG, Fernando. Biografia pinta Lutero como homem moderno, mas intolerante com judeus Folha de São Paulo, 10 de Agosto de 2017. Uma das perguntas ao Matthieu Arnold, professor de história do cristianismo da Universidade de Estrasburgo e autor da obra "Luther", "foi Como o sr. analisa a apropriação do discurso antijudeu luterano pelo nazismo e ainda nos dias atuais?". DUARTE, Fernando. Cinco 'Efeitos Colaterais' da Reforma Protestante de Martinho Lutero BBC Brasil. 31 de Outubro de 2011. "poucas pessoas sabem que Martinho Lutero é apontado como um dos responsáveis pelo sentimento hostil e preconceituoso contra judeus"

${ }^{13}$ TOTA, Antônio Pedro. FTD Sistema de Ensino. SIM: Ensino Médio: História. 1ª Série. 1ª Ed. São Paulo; FTD, 2014. p. 164

14 SALOMÃO, Gilberto Elias. Sistema Poliedro de Ensino. Ensino Médio: História. 1ª Série. Vol. 1.1 Ed. São José dos Campos/SP, 2019. 178-179.

15 Idem, p,179.

${ }_{17}^{16}$ Revolta de Thomas Müntzer.

17 Primeiro que Lutero nas obras "95 teses" e "A liberdade do cristão", era crítico a opressão social e melhoria das condições sociais dos camponeses. Segundo, mesmo não se identificando por diferenças religiosas ao movimento de Munzer, ele intercede diante dos nobres por reformas. E ainda escrevendo a carta "“Admoestação à paz, baseada nos doze artigos dos camponeses de Suábia", ele criticou os príncipes e a nobreza por sua insensibilidade, seus excessos e sua vaidade. E ainda ele os conclama a levar a sério a rebelião e considerar as exigências dos camponeses como razoáveis. Depois fala as camponeses, na mesma carta fala camponeses 
que primeiro não contextualiza o movimento camponês tinha caráter revolucionário armado ameaçando uma estabilidade política, e segundo Lutero, repreende a situação dos camponeses dos nobres, e no momento do conflito crítica à atuação dos dois polos18. E propositalmente só apresentando a reação contrária aos camponeses, como de Tota e Salomão citando o mesmo trecho da carta de Lutero "Exterminando como Cães raivosos"; evidenciando leitura de Febvre, que Lutero renegou seu lugar de origem, recuando em seu discurso para ser instrumento da nobreza, conservação ao status cuo19.

Na obra "Epistemologias e Ensino de História" é apontado que o ensino sobre a Reforma Protestante se apresenta como um período de tensões ou disputas. Utilizando um método de apresentação baseado em conteúdos centrados no cotidiano, a obra lança uma reflexão quanto a formação da consciência histórica. Além do mais, a obra pontua que não há neutralidade na concepção do material didático por parte da equipe de autores ou editoras que compõe o material. Outro ponto de destaque são os objetivos elencados por parte do próprio governo federal na constituição editais para o Programa Nacional do Livro Didático - PNLD, no qual são apresentados os objetivos de cada área.

Além dos livros didáticos (da Área de História) analisados pelo Programa
Nacional do Livro didático - PNLD (programa instituído pelo Ministério da
Educação para a avaliação dos livros didáticos adquiridos por este para
serem distribuídos nas escolas públicas brasileiras), dos Guias dos Livros
Didáticos, de documentos concernentes aos processos de avaliação,
utilizaremos também como fonte de pesquisa os Editais de Convocação
para Inscrição no Processo de Seleção de Livros Didáticos produzidos pela
Comissão Técnica que assessora o Ministro da Educação no tocante a
compra e utilização de materiais didáticos pelo MEC. (BATISTA DE
OLIVEIRA, 2013, p.4)

Por isso, Chartier salienta o papel de historiador, que deve fugir do imediatismo da reminiscência do presente. Em sua prática, não cabe a ele afirmar ou justificar identidades construídas ou reconstruídas próprias de um saber controlado, para se operar ideias sustentadas num discurso histórico daquilo que foi. Em uma época em que nossas relações com o passado estão ameaçadas pela forte tentação de criar histórias imaginárias, é fundamental e urgente à reflexão sobre as condições que permitem sustentar um discurso histórico como representação e explicação adequadas da realidade que foi.

para serem cuidadosos em tomar vossa causa com justiça e boa consciência para não haver excessos. No entanto, os camponeses não ouvindo, caminham para o movimento armado, reagindo com a famosa carta "'Contra os bandos de camponeses roubadores e assassinos", ele não era contra as ideias do movimento, mas sim sua forma armada, devido ao sangue e a pilhagem que estavam fazendo, levando aos seus costumeiros excessos na carta. Por fim, "Uma carta aberta sobre o severo livro contra os camponeses" Qual novamente conclama a paz, como na primeira carta, crítica dois lados por excessos, e principalmente de quer se justificar em pedaços dos seus escritos e não no todo. NICHOLS, Stephen J. Além das Noventa e Cinco Teses: A vida, o pensamento e o legado de Martinho. São José dos Campos, SP: Fiel, 2017. 18

${ }^{19}$ FEBVRE, Lucien. Martinho Lutero, um destino. São Paulo; Três Estrelas, 2012. p. 286-287. 


\title{
4. PRÁtICAS DO ENSINO DE HISTÓRIA E A FORMAÇÃO DE ALUNOS ENQUANTO SUJEITOS HISTÓRICOS
}

Não é possível estudar a Reforma Protestante sem deixar de mencionar a grande invenção de Gutemberg. A criação de um novo sistema de comunicação permitiu não só a divulgação de panfletos com as ideias de Lutero, bem como a publicação da primeira bíblia em língua vernácula. Sendo assim, pode se considerar que no processo de catequese (ou da Educação em si, laica ou sagrada), o êxito do pensamento luterano está na forma de se difundir suas ideias.

Sendo assim, Lutero é não só reformador, mas uma figura que estrutura o Estado Moderno, bem como, o processo de se fazer e pensar a educação. Na busca de utilizar a prensa na divulgação das suas ideias, rompe com um tradicionalismo católico litúrgico que distanciava o rito da vida cotidiana das pessoas. Cabe a nós, professores, a inspiração no pensamento de Lutero quanto as formas e práticas que utilizamos no Ensino de História.

Não quer dizer que todas as tecnologias devem ser utilizadas para o processo didático. Prevalece entre os professores a ideia de que o fracasso na formação da consciência história ou na didática de ensino está em atuar em uma escola sem laboratórios, multimídia, computadores ou conexão. O desafio que se propõe nesse item, não é diretamente ligado aos recursos que se utilizam, mas sim, aos objetivos que fundamentam o fazer no processo de ensino - aprendizagem.

O objetivo dos estudos relacionados a Reforma Protestante e a figura de Lutero devem despertar nos alunos a ideia de valores oriundos do pensamento luterano na construção do Estado Moderno na Alemanha e Inglaterra. Esses valores, se expandiram as atuais democracias defendendo a separação Estado - Igreja, a liberdade e até mesmo a concepção de democracia. A História é a disciplina capaz de realizar esse processo de formação de valores no espaço escolar.

Outro ponto de análise, é que a pensar o processo de constituição da História da Educação está ligado a História da própria igreja, elencando a sua constituição na Idade Média e a transição para a Modernidade, do qual a Reforma constitui um dos pontos de ruptura:

\begin{abstract}
A história da Educação e a história da Igreja mostram-se articuladas sendo, em determinados momentos, fonte de influências recíprocas. Foi na Idade Média que essa relação se mostrou ainda mais intensa sendo a Igreja a única encarregada pela educação escolar que visava à garantia da instrução de seus clérigos, ou seja, bispos e abades procuravam formar crianças e jovens com aspirações à vida religiosa. Dessa maneira, desde o século $\mathrm{V}$, a instrução escolar passa a estar estreitamente ligada às ações da Igreja, sendo ela a responsável pela sua organização e manutenção. (BARBOSA, 2007, p.3)
\end{abstract}

Do período que se estende da Idade Média ao século XIX, as publicações de livros se constituíram na principal forma de difusão do saber escolar e acadêmico, ainda que sua origem tenha base na publicação de obras religiosas. 
As maiores ficções, obras verídicas ou histórias de diversão foram publicadas em livros. No campo da educação, Lutero ampliou a defesa de uma educação pública e de qualidade.

Barbosa (2007) reflete em Lutero a forma como deveria ser organizado um novo processo de ensino, embora, quanto aos seus escritos eles "não chegam a formular uma teoria cristã de educação" (Beck apud Lutero, 1995, p. 301). Esse mesmo pensamento constitui uma análise de que Lutero não queria uma educação sobre a perspectiva cristã, mas sim, uma sociedade empenhada em uma educação de qualidade e formal baseado na compreensão que ele tinha sobre a ideia de dois reinos, apresentada acima.

Além do papel da escola, há um destaque a proposta de currículo elaborada por Lutero. Após suas críticas, sobretudo, as universidades, o luteranismo criticou o pensamento medieval baseado no pensamento aristotélico. Sua proposta retomava a importância do estudo linguístico como elemento indispensável nas escolas. A retomada dos valores humanistas estava em consonância com a difusão de outro acontecimento histórico no momento como o Renascimento na Alemanha e a valorização do grego - latim.

Baseado na ideia de liberdade, Lutero queria que os fiéis fossem capazes de interpretar o texto sagrado. Seus pontos defendiam ainda uma educação pública e obrigatória. Se esse pensamento é encontrado nos pensadores pósrevolucionários da França do Século XIX, é porque antes, esses conceitos foram levantados por Lutero na Reforma Protestante. Nesse sentido, ser professor e lecionar a disciplina de História é ter como eixo norte de que nossos alunos sejam capazes de ler, entender, criticas, modificar e construir o mundo fundamentado em valores.

As práticas de ensino de História devem ser repensadas, na ótica do luteranismo quanto: a concepção de escola, a forma de propagação e construção do saber, a constituição do currículo e o objetivo da educação. Esses são os pontos principais que devem ser considerados pelo professor com a finalidade na formação de alunos enquanto sujeitos históricos.

\section{CONSIDERAÇÕES FINAIS}

Conclui-se que o papel político de Lutero e seus escritos permitem uma nova abordagem dos estudos da Reforma Protestante. Sua atuação sócio-política no processo histórico promoveu mudanças e ressignificação de conceitos na Alemanha e na Inglaterra. Assim, o estudo dessa narrativa possibilita no Ensino de História a formação de alunos enquanto sujeitos históricos.

O escopo deste artigo traze uma nova abordagem para o estudo da reforma, rastreando o papel político na teologia de Lutero e do luteranismo, pautado em seus aparelhos mentais para dimensionar a real imagem das representações, 
apropriações e ressignificações na implicação dos conceitos modernos: laicidade, liberdade, igualdade e democracia.

Portanto, inspirados na construção da narrativas e representações de Martinho Lutero é possível que o professor desenvolva práticas do Ensino de História e possibilitem a formação de alunos enquanto sujeitos históricos. Essa consciência permite construir valores e pensamentos que influenciam a formação do Estado com vistas ao bem comum, pautados pela dignidade, respeito, tolerância, sem perder de vista a liberdade ou a igualdade.

\section{REFERÊNCIAS}

ASEVEDO, Edeílson Matias. Livro Didático de História no contexto do PNLD: avanços e permanências. In: Ensino em Revista. V.17, n.2, jul/dez. Uberlândia, 2010. p.617-634

BARBOSA, Luciane Munir Ribeiro. As concepções educacionais de Martinho Lutero. In: Educação e Pesquisa, v.33, n.1, jan/abr. São Paulo, 2007. p.163-183.

BERMAN, Harold J. Law and Revolution, II: the impact of the protestant reformations on the western legal tradition. Cambridge: Harvard University Press, 2003. p. 1-4.

BRADY JR, Thomas A. The Social History of the Reformation. 1979.

BRAUDEL, Fernand. Escritos sobre História. São Paulo: Perspectiva, 1978

CHARTIER, Roger. A Beira da Falésia: A História entre certezas e inquietude. Porto Alegre; Editora Universidade/UFRGS, 2002.

A ordem do livro: leitores, autores e bibliotecas na Europa entre os séculos XIV e XVIII. Brasília: Editora Universidade de Brasília, 1994.

Editora, 2010.

Roger. A História ou à Leitura do Tempo. Belo Horizonte; Autêntica

FEBVRE, Lucien. Martinho Lutero, um destino. São Paulo; Três Estrelas, 2012

FELIPE, Lúcio Antônio. MATOS, Júlia Silveira. Aprendizagem histórica, ensino de História temática da reforma de Martinho Lutero nos Livros Didáticos. In: Epistemologias do Ensino de História. Porto, 2017. p. 789 -808.

GUIZBURG, C. O Fio e Os Rastros: Verdadeiro, falso, fictício. São Paulo; Companhia das Letras, 2007.

GIDDENS, Anthony. As Consequências da Modernidade. São Paulo; UNESP, 1991.

KANTOVITZ, Geane. As apropriações do saber histórico por meio do livro didático de História da rede salesiana de Escola. In: História \& Ensino, v.20, n.1, jan/jun. Londrina, 2014. p.17-195 
KOSELECK, R. Futuro do Passado: Contribuição à semântica dos tempos históricos. São Paulo; Contraponto, 2006.

LE GOFF, J. História e Memória. Campinas: Editora da UNICAMP, 1990

LOCKE, JOHN. Segundo Tratado sobre Governo Civil. 1689.

, Carta Acerca da Tolerância. 1689.

LUTERO, Martinho. Da liberdade do Cristão (1520): Prefácio à Bíblia. Edição bilíngue São Paulo, UNESP, 1998.

, À Nobreza Cristã da Nação Alemã. 1520.

, Sobre Autoridade Temporal: Até que ponto deve-se obedecer a ela.

LINDEBERG, Carter. História da Reforma. Rio de Janeiro: Thomas Nelson Brasil. 2017. p.53.

NICHOLS, Stephen J. Além das Noventa e Cinco Teses: A vida, o pensamento e o legado de Martinho. São José dos Campos, SP: Fiel, 2017.

OLIVEIRA, Almir Félix Batista de. Livros Didáticos e a escrita da História. In: VII Simpósio Nacional de História: conhecimento histórico e diálogo social. Natal, 2013

PERRY, Marvin. Civilização Ocidental: uma história concisa. 3 ed. São Paulo: Martins Fontes, 2002.

SALOMÃO, Gilberto Elias. Sistema Poliedro de Ensino. Ensino Médio: História. $1^{\text {a }}$ Série. Vol. 1.1aㅡ Ed. São José dos Campos/SP, 2019.

SILVA, Cristiani Barreta. GASPARINI, Helena Gabriela Moellmann. Livro didático e memória - a construção do saber escolar sobre a História de Santa Catarina nas primeiras décadas do século XX. In: Caderno de Aplicação, v.23, n.1, jan/jun. Porto Alegre, 2010. p.35-62

TOTA, Antônio Pedro. FTD Sistema de Ensino. SIM: Ensino Médio: História. 1aㅗ Série. 1ª Ed. São Paulo; FTD, 2014. 


\title{
A MÚSICA COMO FERRAMENTA DOS PROCESSOS DE ENSINO-APRENDIZAGEM
}

\author{
CARVALHO, Maximiliano de \\ Professor efetivo da Rede Publica estadual do estado de São Paul \\ mxmcarvalho@gmail.com
}

\author{
BARBOSA, Natália Aparecida Silva \\ Graduanda em Letras/Inglês - Uni-FACEF \\ Nataliasilvabarbosa6@gmail.com \\ ALVES, Maria Sílvia Rodrigues \\ Doutora em Linguística e Língua Portuguesa - Uni-FACEF \\ masilrodriguesalves@gmail.com
}

\section{INTRODUÇÃO}

A música tem um grande poder de interação e, desde muito cedo, faz parte da vida das crianças despertando diversas sensações tornando-se uma das formas de linguagem que facilita a aprendizagem e desperta a memória das pessoas. Este artigo apresenta a importância da música no processo de ensino-aprendizagem e analisa o papel da música na educação, seus benefícios e suas aplicações no desenvolvimento do estudante dentro da escola.

O presente trabalho tem como objetivo investigar a importância do lúdico no ensino-aprendizagem voltada para jovens do ensino médio, proporcionando aos docentes um melhor entendimento sobre o método de ensino lúdico, como também a sua importância no desenvolvimento escolar. Ainda propõe a reflexão sobre a musicalização na educação e seus efeitos na facilitação da memorização em matérias como português e matemática considerando a importância da música como parte da cultura popular e como conhecimento a ser trabalhado no contexto da educação. Será empregada, como metodologia, a pesquisa bibliográfica, com perspectiva da investigação qualitativa em educação, buscando compreender a importância da música como método de ensino pedagógico na educação.

A pesquisa bibliográfica é feita a partir do levantamento de referências teóricas já analisadas, e publicadas por meios escritos e eletrônicos, como livros, artigos científicos, páginas de web sites. Qualquer trabalho científico inicia-se com uma pesquisa bibliográfica, que permite ao pesquisador conhecer o que já se estudou sobre 0 assunto. Existem, porém, pesquisas científicas que se baseiam unicamente na pesquisa bibliográfica, procurando referências teóricas publicadas com o objetivo de recolher informações ou conhecimentos prévios sobre o problema a respeito do qual se procura a resposta. (FONSECA, 2002, p. 32). 
A música nos mostra que não é somente uma junção de sons e letras, mas sim, um rico auxílio que pode fazer a diferença no ensino porque desperta na pessoa um mundo prazeroso para a mente e para o corpo, o que facilita a aprendizagem e a socialização do aluno no ambiente escolar. Estudiosos como Vygostsky (1988), abordavam a socialização e os aspectos lúdicos que contribuem param a motivação e para a afetividade no trabalho em sala de aula, nos mostra que o ambiente externo interage diretamente no desenvolvimento e na aprendizagem das crianças. Dessa maneira acredita-se que o contato das pessoas com a cultura que as rodeia seja um elemento fundamental para o crescimento saudável.

\begin{abstract}
É na interação com as atividades que envolvem simbologia e brinquedos que o educando aprende a agir numa esfera cognitiva. $\mathrm{Na}$ visão do autor a criança comporta-se de forma mais avançada do que nas atividades da vida real, tanto pela vivência de uma situação imaginária, quanto pela capacidade de subordinação às regras. (Vygotsky, 1984, p. 27).
\end{abstract}

Uma das melhores formas de motivar e estimular a aprendizagem dos alunos no ambiente escolar é trabalhar a música em diversas práticas pedagógicas usando cantigas de rodas e paródias, usando ritmos interessantes e divertidos como samba, rap, pop dentre outros, para demonstrar fórmulas matemáticas, regras de acentuação etc.

A divulgação e preservação da cultura em nossas crianças destacam o trabalho para diversidades culturais, desperta no aluno o interesse e a valorização das atividades artísticas em sua própria escola.

A cultura em cada comunidade pode também influenciar na motivação e interesse do aprendizado de determinados conteúdos tidos como "chatos e maçantes" por muitos alunos "... aula não está em falar coisas prazerosas, mas em falar prazerosamente das coisas...." (CORTELLA, 2006, p.101-128.).

Na sala de aula, quando o aluno está diante de uma situação de aprendizagem que envolva uma determinada regra, o professor (a) utiliza-se de uma melodia ou ritmo conhecido pelos estudantes para facilitar e despertar 0 interesse dos alunos pelo conteúdo. A utilização desta ferramenta torna mais prazerosa e interessante a matéria para os estudantes e consequentemente, há uma maior absorção, interação e compreensão cognitiva durante a aula.

\footnotetext{
O simbolismo está relacionado aos fatores biológicos da mente humana e à evolução desses processos, ou seja, com a capacidade de memória, atenção, percepção e pensamento que no processo evolutivo vão se transformando em processos mentais superiores e que apesar de serem oriundos dos aparelhos biológicos do homem, somente evoluem porque o homem interage com o meio. (Negrine 2002, p. 46)
} 
Também podemos mostrar que nesta interação (professor, aluno e a música) acontece uma importante parceria e com ela o aluno cria uma relação entre o aprendizado e a recreação, desenvolvendo a criatividade e autodisciplina facilitando assim o trabalho do professor em sala.

O docente pode diversificar várias formas de interação com seus alunos como o canto coletivo ou histórias cantadas e musicalizadas (paródias). Assim podem brincar e aprender ao mesmo tempo melhorando a relação professor aluno.

O professor é o mediador entre o conhecimento e o saber do individuo, é a partir dessa mediação que o estudante passa por seu processo de construção do conhecimento. Então, cabe ao educador ter a competência técnica para fazê-lo, ou seja, o docente deverá planejar a sua metodologia voltada para o desenvolvimento do aprendiz, utilizando diversas ferramentas, dentre elas a musicalização, para a facilitação do aprendizado.

A possibilidade em trabalhar a música (melodia e ritmo) para desenvolver as habilidades e as competências necessárias para ampliar 0 ambiente cognitivo, contextualizando os conteúdos considerados "difíceis", tornam-se menos complexos no ensino de matemática e português. Este tem se tornado um poderoso instrumento para desenvolver diferentes linguagens: verbais, musicais, matemáticas e gráficas, permitindo a discussão de diversos conceitos de forma lúdica e prazerosos inclusive incentivados pelos Parâmetros Curriculares Nacionais.

Assim pretendemos discutir a proposta para que os professores possam usar estratégias diferenciadas nas aplicações metodológicas que cumpram as metas de aprendizagem estabelecidas pelo MEC, unindo o lúdico ao conhecimento científico e específico de Matemática e diversas regras da Língua Portuguesa.

\section{APLICABILIDADE E DIDÁTICA DE ENSINO COM O USO DA MÚSICA}

Podemos diversificar várias formas de interação: canto coletivo ou histórias cantadas e musicadas (paródias). Assim podemos brincar e aprender ao mesmo tempo.

A possibilidade em trabalhar a música (melodia e ritmo) para desenvolver as habilidades e a competência necessárias para ampliar 0 ambiente cognitivo, contextualizando os conteúdos considerados "difíceis", torna o ensino de matemática menos complexo. Este tem se tornado um poderoso instrumento para desenvolver diferentes linguagens: verbais, musicais, matemática e gráfica, permitindo discutir diversos conceitos de forma 
lúdica e prazerosa inclusive incentivada pelos Parâmetros Curriculares Nacionais.

Outro importante motivo que nos leva a usar a música no ensino de diversos conteúdos de Matemática e Português é a vontade de muitos educadores encontrarem outros caminhos para diversificar suas aulas, saindo do tradicional, ou seja somente aulas expositivas e proporcionar aos seus educandos aulas diferenciadas que todos almejam e preferem.

Muito são os motivos que diversos educadores não utilizam este poderoso instrumento didático, alegando falta de tempo, recursos ou não ter conhecimento técnico. Mas o caminho seria procurar melodias e ritmos bem simples para tornar o trabalho eficaz e de fácil implementação.

Assim pretendemos discutir a proposta para que os professores possam usar estratégias diferenciadas na aplicação metodológica que cumpram as metas de aprendizagem estabelecidas, unindo o lúdico ao conhecimento científico e específico de Matemática e diversas regras da Língua Portuguesa.

\section{O LÚDICO NA FORMAÇÃO DO EDUCADOR}

É através do lúdico que o professor pode desenvolver atividades divertidas que saem da rotina, proporcionando uma maior interação entre o docente e o discente. Por isso é de fundamental importância a formação do professor, o qual é o mediador para a construção do conhecimento dos estudantes. É através da formação que o seu desenvolvimento e metodologia de ensino em sala de aula serão transformados, por meio do conhecimento adquirido anteriormente e na sua formação continuada, procurando sempre saber novos métodos e formas de mediar o aprendizado do conteúdo para os seus alunos, a formação do educador juntamente com a ludicidade deverá estar organizada em aprendizagens significativas, sempre procurando assimilar a realidade da criança com o conteúdo abordado, fazendo com que ela interaja e vivencie o conteúdo para haver uma melhor memorização.

Assim sendo, a ludicidade traz inúmeros benefícios para a aprendizagem tanto para quem está aprendendo como para o professor que está ensinando, por que é satisfatório para o professor ver a interação e uma maior participação dos alunos em sala através do lúdico. Diante disso, o lúdico vem crescendo e mostrando para os educadores a sua relevância e significado na educação, quebrando as barreiras que ainda nos dias de hoje podemos observar em sala de aula, em que a musicalização, e a ludicidade não são utilizadas em sala. Diante disso, Freire discute que: 
"[...] na formação permanente dos professores, o momento fundamental é o da reflexão crítica sobre a prática. É pensando criticamente a prática de hoje ou de ontem que se pode melhorar a próxima prática [...]." (FREIRE, 1998, p.43-44).

O professor deve estar sempre atualizado, buscar formas diferenciadas de ensino e aprendizagem com o objetivo de transformar o ensino e a educação, dentro de uma visão mais criativa e dinâmica, é um atributo que todo educador deve procurar, facilitando a construção do conhecimento de seus estudantes e reinventando a prática, construção e reconstrução de suas metodologias para aprimorar e melhorar constantemente o seu trabalho.

\section{OBJETIVOS}

Os principais objetivos a serem alcançados seriam: facilitar o ensino, fixar conteúdo abordado em sala de aula, criar aulas lúdicas e interessantes, incentivar a participação e atrair a atenção do aluno para o conteúdo abordado.

O fato do ensino de matemática e português perpassarem por um constante desenvolvimento de metodologias, trazendo fortes modificações nos procedimentos conteúdos e metas com o ensino por meio da música Ausubel, (1982) cita dois tipos de aprendizagem: a mecânica e a significativa. A aprendizagem mecânica contempla a memorização muito usada antigamente, porém a significativa mostra ao aluno, novas formas de se obter e compreender as informações voltadas para a própria estrutura mental pré-existente.

O trabalho é voltado para alunos do ensino médio, no qual existe a necessidade dessa inovação metodológica devido ao fato de que várias outras propostas mais tradicionais na educação, como projetos, simpósios, seminários e outros programas de governo que não conseguiram contemplar todos os resultados almejados.

A experiência como professores de matemática ou português, observa-se que é evidente a preferência dos alunos por aulas com músicas e compartilhar esta experiência com outros colegas de trabalho é primordial para aperfeiçoar a nossa prática docente. Pretendemos, dessa forma, contribuir para uma melhoria considerável ensino-aprendizagem de matemática e português almejando formar alunos mais participativos, transformadores e capazes de interagir e estudar de forma mais criativa e eficiente.

Aprender novas linguagens matemáticas ou gramaticais é uma das principais metas a serem alcançadas por meio da música. De acordo com Lima (2004) o uso de músicas possui diferentes alvos. Além dos aspectos 
linguísticos como aquisição de vocabulário compreensão da gramática, expressão oral e outros que envolvem a cultura regional ou não.

Também de acordo com Dommel \& Sacker (1986) apud Rosin s/d precisamos considerar o aspecto emocional do aprendiz, desenvolvendo habilidades como maior sensibilidade e criatividade. A aprendizagem deve fomentar atitudes de motivação autoconfiança, ansiedade e medo. Assim os alunos apresentam melhor desempenho dos que os que se apresentam ansiosos ou com mede de se expor aos colegas.

RIDDIFORD (1998) diz que "A música promove um ambiente relaxado, lúdico com baixo stress que é muito propício para a aprendizagem...". Este é um fator importante para que os alunos possam se sentir mais a vontade e possam, consequentemente, aprender mais. Também segundo MURPHEY (1992) "A linguagem aprendida por meio da música pode ser assimilada mais naturalmente em maior quantidade e com melhor fixação”.

Os comerciais de TV e rádio usam recursos de músicas mnemônicas com ritmo, melodia e letra, por meio de paródias em diversas campanhas políticas, estabelecimentos, produtos, prestação de serviço e marcas, de fácil assimilação, fixando conteúdos, contextos e conceitos a serem vendidos. Este é um recurso que também podemos utilizar, já que pretendemos ensinar por meio da música.

Ferreira (2010) define música como uma forma de convívio humano desde a época do começo da civilização e que ela surgiu mesmo antes da comunicação verbal e oral.

\section{MÚSICA E CONTEÚDOS: PROPOSTAS DE PARÓDIAS PARA PORTUGUÊS E MATEMÁTICA}

Apresentaremos algumas possibilidades de músicas a serem utilizadas em conteúdos de português e matemática. Tratam-se, apenas, de exemplos interessantes coletados no decorrer desta pesquisa e de formatos que nós, como professores, já experimentamos em nossos contextos.

5.1. Exemplos de música para trabalhar o conteúdo deTrigonometria

REFRÃO:

Um dois três, três dois um

Tudo sobre dois

CARVALHO, Maximiliano de; BARBOSA, Natália Aparecida Silva; ALVES, Maria Sílvia 
Raiz de três, sobre três

Um raiz de três

A Trigonometria parece com a sua tia

Num banho na bacia e cheia de mania

Ao sinal pro recreio o seno vai correndo

O cosseno está caindo, a tangente a coca está bebendo

Preste muita atenção, na sua equação

Resolvendo a operação, encontramos a razão

Esta música tem a melodia do "dingo bells" tem o objetivo de focar o aprendizado e fixação da tabela importante de valores que podemos usar em razões trigonométricas no triangulo retângulo, as quais são necessárias para responder e avaliar situações problema que envolvam aos valores de seno, cosseno e tangente. Para uma melhor compreensão é preciso comparar os valores e formulação com a letra da música.

Refrão:

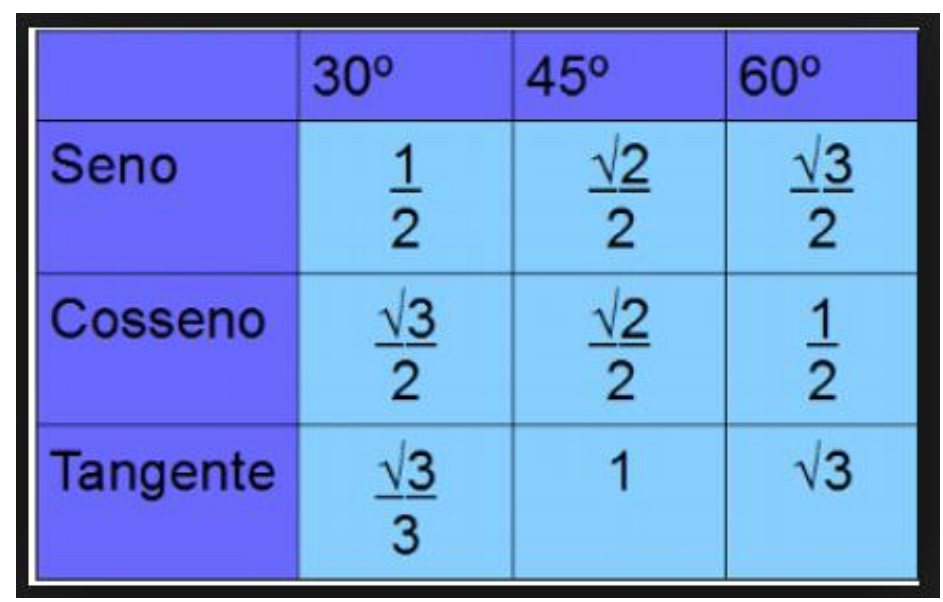

Para as razões trigonométricas, teremos:

$\mathrm{CO}$ (cateto oposto)

CA (cateto adjacente)

$\mathrm{HI}$ (hipotenusa)

o seno vai correndo

\section{$\frac{\mathrm{CO}}{\mathrm{HI}}=\frac{\text { cateto oposto }}{\text { hipotenusa }}=\mathrm{COHI}($ corri)}


O cosseno está caindo

\section{$\frac{\mathrm{CA}}{\mathrm{HI}}=\frac{\text { cateto adjascente }}{\text { hipotenusa }}=\mathrm{CAHI}$ (cai)}

a tangente a coca

$$
\frac{\mathrm{CO}}{\mathrm{CA}}=\frac{\text { cateto oposto }}{\text { cateto adjascente }}=\mathrm{COCA}
$$

5.2 Exemplos de música para trabalhar o conteúdo de

Acentuação

É a regra de acentuação $(5 \mathrm{x})$

Pra começar

Vamos considerar

As ultimas silaba

Forte a falar

Prestando atenção

pra classificar

naquelas palavras

vamos acentuar

acentuam-se as palavras

oxítonas terminadas

AEO EM acondicionadas

Primeira regra

A ser cantada

Que estão correlacionadas

Paroxítonas terminadas 
I IS UM UNS US

L N R X

$\tilde{A}, A S, \tilde{A} O, \tilde{A} O S$

Segunda regra

Pra ser cantada

E pra terminar

Todas acentuar

Proparoxítonas

A considerar

Nesta música usamos o ritmo "rock you" a própria letra já é autoexplicativa, trata-se de regra de acentuação das palavras:

- OXÍTONAS: são palavras que tem a última sílaba pronunciada mais forte, acentuam-se as palavras oxítonas terminadas em a, e, o, em.

- PAROXÍTONAS:são palavras que tem a penúltima sílaba pronunciada mais forte, acentuam-se as palavras paroxítonas terminadas em i, is, um, uns, us, I,n,r,x,ã,ãs,ão, ãos.

- $\quad$ PROPAROXÍTONAS: são palavras que tem a antepenúltima sílaba pronunciada mais forte, acentuam-se todas as proparoxítonas.

5.3 Outro exemplo para o conteúdo regras de acentuação

Na regra de acentuação

Ainda estamos com cartas na mão

Por isso preste atenção

Nestas palavras e sua construção

A Célia é uma bancária

Vai na indústria e na sua farmácia

Acentuam-se essas palavras

Em ditongo crescente terminadas 
Réu, chapéu, céu

Já estamos no beleléu

Herói, destrói, dói

Os coronéis em Niterói

Acentuam-se essas palavras

Em éi, éu, oi terminadas

Com a saída do senhor Luís

Atraí o ciúme do seu país

Acentuam-se i u tônicos

Em hiato seguidos ou não de s (falar esses)

A música é cantada em formato de ritmo de samba, com rimas que mostram diversos exemplos de palavras que interagem umas com as outras com determinado grau de sentido, para que o cérebro possa relacionar o texto às regras gramaticais.

Observe que quando cantamos herói, destrói, dói, essas palavras estão intimamente ligadas a filmes de ação que todos os jovens adoram, mas também é um elo de ligação e exemplificação com a regra de acentuação das palavras que terminam em ói.

É claro que a música não deve ser utilizada sem uma breve e antecipada exposição e explicação do professor, para que o aprendizado se torne eficaz, coerente e que tenha o sentido necessário.5.3 Com função de segundo grau

Be ao quadrado menos quatro a c

É assim que você vai aprender

Menos $b$ raiz delta dois a

$\mathrm{O}$ x você vai calcular

Na função do segundo grau

A raiz é fundamental

O valor máximo se acha o tal 
Mas o valor mínimo já está legal

$\mathrm{Na}$ função do segundo grau

"A" mais sorrindo se acha o tal

"A" menos triste é um bossal

Aprendendo assim é mais legal

A canção da função do segundo grau é cantada com o ritmo de samba. Ela tem o objetivo de auto explicar como calcular as raízes da função e os valores máximos e mínimos da parábola, que são curvas necessárias para demonstrar esta função.

Figura 1 - Raízes função do segundo grau

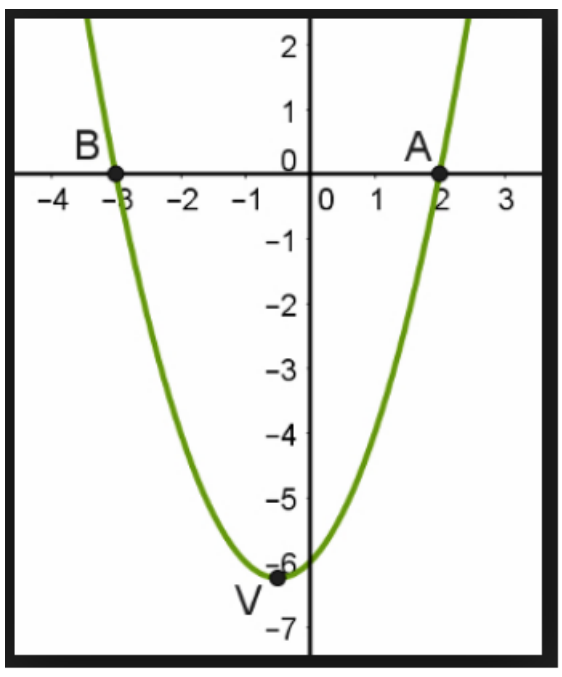

As raizes são os pontos $\mathrm{A}, \mathrm{B}$

$O$ vértice é o ponto $\mathbf{V}$

Sorrindo - concavidade para cima

Triste - concavidade para baixo

Para calcular suas raízes é necessário saber a fórmula de "Bhaskara", um importante matemático, professor, astrólogo e astrônomo. Nasceu e viveu na Índia de 1114 a 1185. Ele foi quem descobriu a famosa fórmula para calcular as raízes da função do segundo grau:

$$
\begin{aligned}
\Delta & =b^{2}-4 . a . c \\
x & =\frac{-b \pm \sqrt{\Delta}}{2 a}
\end{aligned}
$$


5.4 Com função do primeiro grau

Na função do primeiro grau

Calcular a raiz é fundamental

Mas se você se acha o tal

A razão errada vai se dar mal

Se você já calculou a raiz

Observe bem o que eu já fiz

A reta corta onde fica o xis

Você aprendendo é o que eu sempre quis

Quando a reta está subindo

Coeficiente "a" é positivo

Mas se a reta está descendo

Coeficiente "a" é negativo

Agora vamos aprender o "b"

Verificando a reta é melhor pra você

Eixo y corta o valor "b"

Negativo ou positivo temos que aprender

A música é cantada em formato de ritmo "batalha de rap", com rimas para tornar o texto mais atrativo e engraçado, é claro que deve ser contextualizado e explicado anteriormente para que fornecer sentido ao aluno. E de preferência cantar a música demonstrando quais são os elementos da função do primeiro grau.

A primeira e a segunda estrofes levam o aluno a realizar e conferir se o cálculo está correto. Visualizando o valor correto da raiz, para determinar e construir o gráfico, demonstrando onde intercepta o eixo das abscissas.

$\mathrm{Na}$ terceira, o professor pode explorar o conteúdo explicando o que seria o coeficiente angular e o que irá determinar se a reta estará mais 
próximo do ângulo de 90 graus, inclinada para frente ou para trás, conforme o sinal do valor "a" na função.

Finalizando com o valor "b", que seria valor onde a reta intercepta o eixo das ordenadas. Exemplos:

Figura 2 - Função de $1^{\circ}$ grau

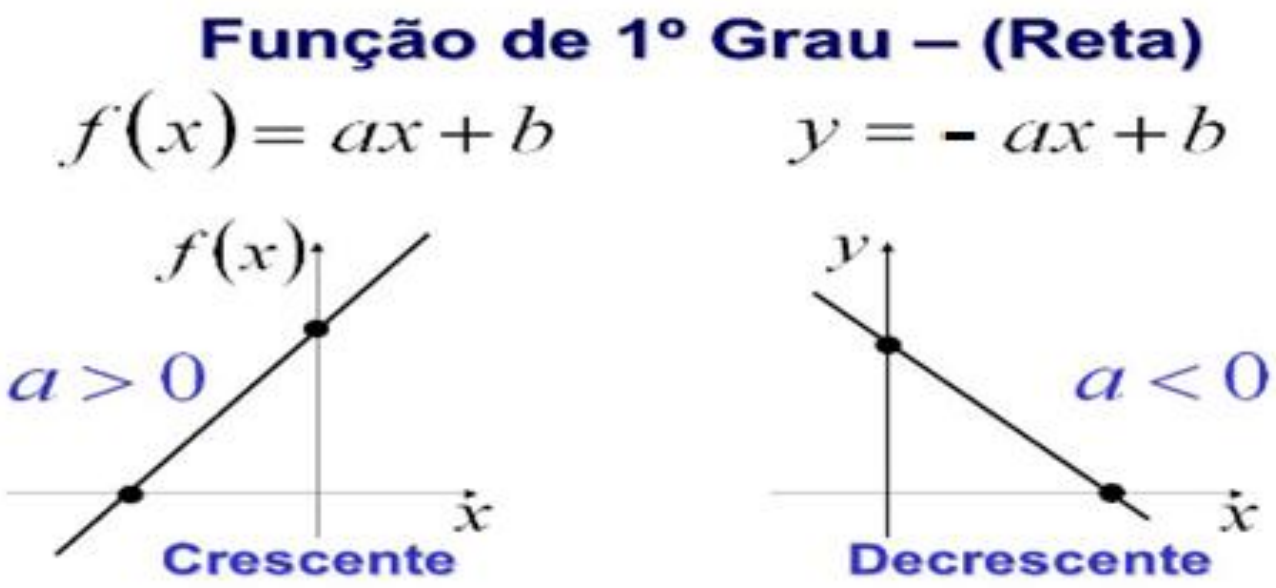

\subsection{Análise combinatória}

Para a análise combinatória

A probabilidade junto nesta história

São as possibilidades na trajetória

Considerando as chances pra sua vitória.

Permutação ene fatorial

Quantidade de pessoas levanta o astral

Considerando os alunos no total

O mapa de sala é fundamental

O arranjo é pra você

Ene fatorial por ene menos pe

Fatorial é a fórmula de

Considerar a ordem para aprender 
Aqui já chegamos na combinação

É igual ao arranjo sem repetição

Acrescenta o pe fatorial pra comissão

Fechando o assunto à compreensão.

Falando em probabilidade

No jogo é o bastante pra felicidade

Na fração ou porcentagem

A previsão do evento para a contagem

Os processos mnemônicos devem conter palavras marcantes ou frases de efeito, pois estas levam o cérebro a correlacionar os fatos vistos nas situações problema, demonstrados pelo professor em sala de aula.

Nesta paródia, foram inseridas algumas palavras como: mapa de sala, ordem e comissão. Para que estas tenham a significância necessária, é preciso considerar as questões abaixo:

1) Na sala do segundo ano do ensino médio há 40 alunos frequentes. De quantas maneiras diferentes o professor poderia fazer o mapa de sala (disposição e organização dos alunos)?

2) Na sala do segundo ano do ensino médio há 40 alunos frequentes. De quantas maneiras diferentes os alunos poderiam eleger uma comissão de formatura com 3 cargos: presidente, vice e tesoureiro?

3) $\mathrm{Na}$ sala do segundo ano do ensino médio há 40 alunos frequentes. De quantas maneiras diferentes os alunos poderiam eleger uma comissão de formatura com 3 representantes de sala?

Utilizando as fórmulas da análise combinatória simples teríamos:

Combinacões simples

$\mathrm{C}_{\mathbf{n}, \mathbf{p}}=\frac{\mathbf{n} !}{\mathbf{p} !(\mathbf{n}-\mathbf{p}) !}$
Arranjos simples

$A_{\mathbf{n}, \mathbf{p}}=\frac{\mathbf{n} !}{(\mathbf{n}-\mathbf{p}) !}$ $\underline{\text { Permutacões simples }}$

$$
\mathbf{P}_{\mathbf{n}}=\mathbf{n} !
$$

$$
!=\text { fatorial } \Rightarrow 3 !=3 \cdot 2 \cdot 1=6
$$

n = número total no grupo de estudo p = parte do grupo de estudo

Lembre-se que Combinação não importa a ordem e Arranjo sim, importa a ordem dos elementos do grupo. 


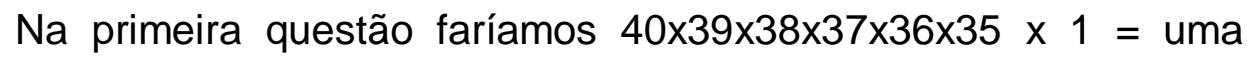
quantidade imensa de permutações, os alunos trocariam de lugar dentro da sala para formar novos mapas de sala.

$\mathrm{Na}$ segunda questão seriam $40 \times 39 \times 38$ os arranjos foram reduzidos para 59.280. Quando a sala elege o presidente, vice e o tesoureiro para a comissão de formatura, neste caso importa a ordem, considerando o primeiro, segundo e terceiro lugar na competição.

Finalizando com a terceira questão, ficaria 59.280 dividido por 6 , redução para 9880 combinações, neste caso seria dividido por 3 fatorial ou seja $3 \times 2 \times 1=6$, excluindo todas as possibilidades de repetição, porque as três pessoas teriam o mesmo grau de importância, desconsiderando a ordem dos elementos desta comissão de representantes de sala.

A primeira estrofe faz um elo entre as diversas possibilidades e a probabilidade de ocorrer um evento qualquer "vitória" nos jogos de carta, dados etc.

A segunda, terceira e quarta estrofes falam sobre as fórmulas e fornecem dicas importantes sobre as questões acima citadas.

Finalizando com a quinta estrofe que fala sobre probabilidade cálculo em formato de fração e porcentagens.

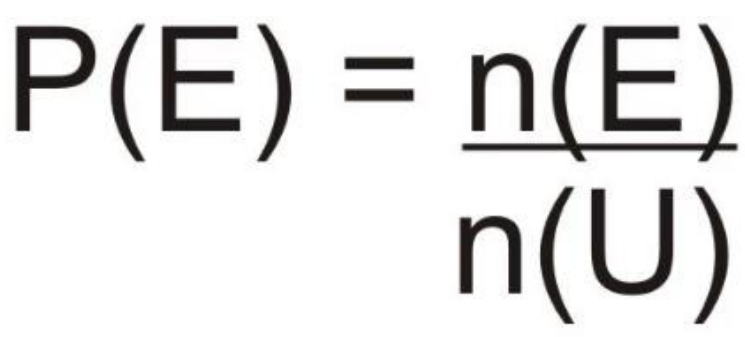

$\mathrm{P}(\mathrm{E})=\mathrm{PROBABILIDADE}$

$\mathrm{n}(\mathrm{E})=\mathrm{EVENTO}$

$\mathrm{n}(\mathrm{U})=$ ESPAÇO AMOSTRAL (TODAS AS POSSIBILIDADES)

\section{CONSIDERAÇÕES FINAIS}

Ao iniciarmos este trabalho pretendíamos ressaltar a importância do lúdico no processo de ensino-aprendizagem, investigando a importância da música voltada para jovens do ensino médio, proporcionando aos docentes um melhor entendimento das competências trabalhadas dessa maneira, como também a sua importância no desenvolvimento escolar. Ainda propomos uma reflexão sobre a musicalização na educação e seus efeitos na facilitação da memorização em matérias como português e matemática considerando a importância da música como parte da cultura popular e como conhecimento a 
ser trabalhado no contexto da educação. Vemos que, no decorrer da pesquisa, no suporte teórico, encontramos respaldo para confirmar que a utilização do ensino lúdico através da música os estudantes conseguem ter uma melhor aprendizagem e memorização de tabelas, gráficos ou até mesmo enunciados que antes não eram facilmente recordados por eles. Apresentamos, também, alguns exemplos de canções utilizadas com 0 intuito de facilitar a aprendizagem e ainda pudemos perceber uma escassa participação de trabalhos neste assunto.

Foi empregada, como metodologia uma pesquisa bibliográfica, com perspectiva da investigação qualitativa em educação, que buscava compreender a importância do ensino lúdico como método de ensino pedagógico na educação o que foi constatado de acordo com as teorias de Vygotsky e Freire.

$E$, com esta pesquisa constatamos que a musica é uma prática natural de todo ser humano que toca a alma, encanta, fascina e por isso ela facilita a aprendizagem. O educando se envolve nos conteúdos trabalhados, quando relacionados com a música. A música, além de ser uma prática artística é também uma conexão entre conceitos cognitivos, motores, sociais e afetivos, agem como um poderoso instrumento para transformar o complicado e difícil em algo prazeroso e de fácil assimilação e adequação das diversas situações cognitivas necessárias para um bom andamento nas práticas e metodologias em sala de aula.

Esperamos que o presente artigo fomente os professores a se utilizarem das abordagens aqui apresentadas, mostramos suas importâncias e ressaltamos os teóricos que favorecem tais aplicações. Desse modo, queremos que o presente trabalho sirva de estímulo para a aplicação dessas ferramentas nos conteúdos de português e de matemática para que o ensino possa cumprir a sua função.

\section{REFERENCIAS}

AUSUBEL, D. P. A aprendizagem significativa: a teoria de David Ausubel. São Paulo: Moraes, 1982

MEC.Base Nacional Comum Curricular: A área de matemática e suas tecnologias,p. 516-520 Disponível em: file://C:/Users/20227/Downloads/BNCC_EnsinoMedio_embaixa_site.pdf Acesso em 16 maio. 2019

CORTELLA, M. S. A escola e o conhecimento: Fundamentos Epistemológicos e Políticos cap. 3. A escola e a construção do Conhecimento: EDITORA CORTEZ, 2006, p.101-128. 
DOMMEL, H.; SACKER, U. Liederund rock imdeutschunterricht. München, Goethe-Institut, 1986.

ENSAIO PESQUISA EM EDUCAÇÃO EM CIÊNCIAS, vol. 15, núm. 1, eneroabril, 2013, pp. 81-94 Universidade Federal de Minas Gerais Minas Gerais, Brasil. Disponível na internet:

http://www.redalyc.org/articulo.oa?id=129526291006 Acesso em 25 maio. 2019

FERREIRA, M. Como usar a música em sala de aula. São Paulo: 7.ed. Contexto: 2010.

FREIRE, Paulo. POLÍTICA E PEDAGOGIA de Antônio Novoa, Michael W. Apple Edição/reimpressão: 09-2005 Editor: Porto Editora 1998, p.43-44

FONSECA, J. J. S. Metodologia da pesquisa científica. Fortaleza: UEC, 2002. Apostila, p. 32.

JESUS, J.Y.T. Música na escola como um recurso pedagógico: análise de uma prática docente em salas de séries inicia. 2002. Dissertação (Mestrado em Educação) - Universidade Federal de São Carlos,São Carlos, 2002.

LIMA, L. R. O uso de canções no ensino de Inglês como língua estrangeira: a questão cultural. 1 ed. Salvador: EDUFBA, 2004, v. 1, p 173 - 192.

NEGRINE, Airton. Simbolismo e Jogo. In: SANTOS. Santa Marli Pires dos. Brinquedoteca: o lúdico em diferentes contextos. $7^{a} \underline{a}$ Edição. Petrópolis, RJ: Vozes, 2002, p. 46.

MURPHEY,T. Music \& Song. Oxford: Oxford University Press USA, 1992 PIAGET, Jean. A equilibração das estruturas cognitivas. Problema central do desenvolvimento. Rio de Janeiro: Zahar, 1976.

. Psicologia e Pedagogia. Rio de janeiro: Forense Universitária, 1976.

PORTAL APRENDIZ. Instituto utiliza música como instrumento de inclusão social. Disponível na internet: <http://aprendiz.uol.com.br/content/phetestedr.mmp> Acesso em 9 maio. 2019.

RIDDIFORD, Nicky; FRANK, Edwards,; GWILLIM, John. Song talk: sons for English language-learnin, elementary level. Wellington, N.Z: National Association of ESOL Home Tutor Schemes (Inc.), 1998.

VIGOTSKY, Lev Semenovich. A formação social da mente. São Paulo: Martins Fontes, 1984, p. 26-29.

VIGOTSKY, L. S.; LURIA, A. R.; LEONTIEV, A. N. Linguagem, desenvolvimento e aprendizagem. Tradução de Maria da Penha Villalobos. 2. d. São Paulo: ĺcone, 1988, p. 103-117. 


\title{
A RELEVÂNCIA DA BRINCADEIRA SIMBÓLICA NAS PRÁTICAS PEDAGÓGICAS VOLTADAS ÀS CRIANÇAS DE 6 ANOS DE IDADE
}

\author{
MALTA, Deise Aparecida Silva \\ Universidade Federal de São Carlos \\ deisesmalta@hotmail.com \\ NICOLIELO, Maria Elisa \\ Universidade Federal de São Carlos \\ linicolielo@hotmail.com \\ SOMMERHALDER, Aline \\ Universidade Federal de São Carlos \\ sommeraline1@gmail.com
}

\section{INTRODUÇÃO}

Esse texto tece considerações sobre o brincar a partir do objetivo de identificar como a imaginação opera na brincadeira simbólica de crianças de 6 anos de idade, bem como, o sentido que estas atribuem aos objetos no ato de brincar.

Defende-se a ideia de que ao inserir crianças de 6 anos de idade no Ensino Fundamental, o seu direito de continuar brincando deve ser garantido na escola, conforme estabelece o art. 11 das Diretrizes Nacionais Curriculares da Educação Infantil:

\begin{abstract}
Art. 11. Na transição para o Ensino Fundamental a proposta pedagógica deve prever formas para garantir a continuidade no processo de aprendizagem e desenvolvimento das crianças, respeitando as especificidades etárias, sem antecipação de conteúdos que serão trabalhados no Ensino Fundamental. (BRASIL, 2009, p.5).
\end{abstract}

A ampliação do Ensino Fundamental exige uma preocupação com o tempo dedicado às atividades lúdicas, brincar espontaneamente e de forma direcionada deve ser uma prática cotidiana com crianças nessa faixa etária (BORBA, 2007).

Corroborando com essa ideia revisitamos a teoria de Vygotsky (1998) que afirma que se o adulto não proporciona bons lugares para brincar, espaços simbólicos, mediações e materiais pode-se dificultar 0 desenvolvimento mental da criança. Daí a importância da mediação, de repertoriar a criança e ampliar ao máximo a sua capacidade imaginativa. $O$ autor ressalta que o objeto favorece a criação da criança e que o contexto determina como ela brinca. Segundo a sua teoria o jogo está diretamente 
relacionado com a criação, e este configura uma atividade extremamente criativa.

Conforme nos ajuda a refletir, Lima (2007), a imaginação favorece a aprendizagem, ela não nasce com o individuo, é construída através das experiências vivenciadas. Por este motivo, também faz parte do processo de aprendizagem e deve ser considerada no planejamento do professor.

Temos aí duas implicações importantes: primeiramente, que a imaginação não é dada na espécie, é construída. Segundo, que ela é parte integrante do processo de aprendizagem, porque aprender significa, exatamente, ser capaz de estabelecer conexões entre informações, construindo significado. Podemos ver que, neste segundo caso, a imaginação é base para o estabelecimento destas novas redes, uma vez que ela é a função psicológica que estabelece relações significativas entre elementos que não estavam conectados entre si (LIMA 2007, p. 23).

Partindo desse pressuposto, a observação proposta teve o intuito de compreender se as crianças de 6 anos, no momento de transição entre a fase do jogo simbólico para o jogo de regras, ainda se interessam pela brincadeira simbólica por meio de objetos diversos como: tocos de madeira, retalhos de tecidos, tampinhas de garrafa, etc. Considerando que a imaginação favorece a aprendizagem, a observação realizada verificou se através destes objetos as crianças expressam sua criatividade.

Os dados foram analisados partindo do referencial teórico dos estudos de Piaget (1971), desse modo, para esclarecer ao leitor a teoria que embasa a pesquisa, faremos uma breve explanação referente aos três tipos de estruturas que caracterizam o jogo infantil: o exercício, o símbolo e a regra.

Conforme os estudos de Piaget (1971), a brincadeira é essencial para o processo de desenvolvimento e aprendizagem da criança. $O$ autor refere-se à nomenclatura "jogo" o ato de brincar. De acordo com Sommerhlader e Alves (2011) o jogo é um elemento fundamental, por propiciar à criança a oportunidade de resolver situações problema que surgem a partir de sua interação com o meio.

Conforme a concepção piagetiana sobre o jogo, este se divide em diferentes fases. Para Piaget (1971), o jogo nasce nos estágios iniciais do desenvolvimento. "Quase todos os comportamentos [...] são suscetíveis de se converter em jogo, uma vez que se repetem por assimilação pura, isto é, por simples prazer funcional." (PIAGET, 1971, p.117).

Piaget (1971) também classifica o jogo infantil em: jogos de exercício, simbólico e de regra, estas fases são amarradas com o desenvolvimento cognitivo. Para o autor a qualidade do estímulo e da interação 
é que vai operar sobre o desenvolvimento e favorecer a criança sair do jogo de exercício e chegar ao jogo de regras. "Exercício, símbolo e regra, tais parecem ser as três fases sucessivas que caracterizam as grandes classes de jogos, do ponto de vista de suas estruturas mentais." (PIAGET, 1971, p.148).

O jogo de exercício compreende o período de desenvolvimento sensório-motor presente em média nos primeiros dezoito meses de vida. Nesta fase predomina a repetição, o bebê, faz algo repetidas vezes com sentido lúdico pois, esta repetição gera fonte de satisfação. Os jogos de exercício não supõem o pensamento, entretanto as aprendizagens adquiridas nessa fase são base para futuras operações mentais.

[...] os jogos de exercício são formas de, por seu prazer funcional, repetir por exemplo, uma sequencia motora e por isso formar um hábito. Os hábitos como analisa Piaget em seu livro La Naissance de l'inteligence chez l'enfant (1936), são a principal forma de aprendizagem no primeiro ano de vida e constituem a base para as futuras operações mentais. (MACEDO, 1995, p.6).

O jogo simbólico compreende em média o estágio que vai dos 18 aos $6-7$ anos, caracteriza-se pela representação de um objeto que não esteja no campo de visão da criança. A partir dos dois anos de idade ela têm a capacidade de representar mentalmente um objeto ausente e compreender as coisas, pois, seu significado pode ser imaginado por elas. Através da brincadeira a criança constrói significado. O jogo simbólico ou faz-de-conta, possui como característica a assimilação deformante, ou seja, a criança assimila a realidade conforme pode ou deseja de acordo com seu limite cognitivo. Entretanto essa simbolização é fundamental para futuras aprendizagens escolares, afirma Macedo (1995).

Piaget afirma que aos 6 anos os jogos simbólicos começam a declinar, as brincadeiras nesse período passam a ser uma representação da realidade, havendo uma preocupação com a verossimilhança, "essas construções coordenam cada vez mais o exercício lúdico sensório-motor e intelectual com o próprio símbolo" (PIAGET, 1971, p.176).

O Jogo de regras abrange ao estágio que vai dos 6-7 anos em diante. Nesta fase há uma regularidade definida coletivamente, as regras substituem os símbolos e a sua violação não é aceitável. Essa ação exige habilidades do jogador para enfrentar e solucionar problemas e para ganha-lo, visto que, nessa fase o jogo tem um caráter competitivo.

[...] os jogos de regras são jogos de combinações sensóriomotoras (corridas, jogos de bola de gude, ou de bolas etc.) ou intelectuais ( cartas, xadrez etc.), com competições dos indivíduos(sem que as regras seria inútil) e regulamentados quer por um código transmitido de gerações em gerações, quer por acordos momentâneos (PIAGET,1971, p.187). 
De acordo com a teoria de Piaget (1971) as crianças passam por fases em seu desenvolvimento, aos seis anos elas começam a fazer trocas entre si deixando de concentrarem-se em si mesmas (egocentrismo) algo que ele chama de reciprocidade. O próximo estágio a ser alcançado é denominado de jogo de regras, nesse período há uma regularidade no jogo e as regras são o elemento principal.

Diferentes perspectivas explicam o ato de brincar: o enfoque educacional aborda a brincadeira como instrumento relevante no desenvolvimento e/ou aprendizagens das crianças; o antropológico refere-se ao brincar como uma ação que reflete valores, hábitos ou seja, a cultura de uma sociedade; o sociológico discute a influencia do contexto social nas brincadeiras, já a psicologia afirma que através da brincadeira é possível compreender as emoções a psique e a personalidade do indivíduo.

Referente às contribuições da psicanálise como matriz teórica podemos afirmar que na brincadeira há relação do desejo, que por sua vez, origina-se da ordem do inconsciente. Para Freud (1968), o inconsciente é profundo, 'uma caixa preta', entretanto, ele aparece na brincadeira. De acordo com o autor, o brincar é uma linguagem humana em que conseguimos acessar esse inconsciente pelo fato dele se manifestar na brincadeira. Freud (1968) explica que a brincadeira é uma experiência privilegiada em que desejos da ordem do inconsciente podem ser realizados, fantasias que na vida real não poderiam se concretizar, ao brincar a criança pode fazer coisas impossíveis. Desse modo, o ato de brincar se constitui em um relevante elemento para uma estruturação psíquica saudável. Para Freud, a brincadeira é a tarefa favorita e mais intensa da criança.

[...] o elemento essencialmente terapêutico no jogo está em que, através dele, a criança aprende a controlar, na sua fantasia, impulsos que são até então, difíceis para ela controlar, na fantasia, impulsos que são, até então difíceis para controlar na realidade. E com frequência o seu modo preferido de tratar com algum aspecto da realidade que apresenta dificuldades insuperáveis para uma abordagem direta. Nesse tipo de situação, a participação de outras crianças e do orientador é quase sempre um fator vital. (FREUD apud COURTNEY, 1980, p.80 )

Na concepção de Winnicott (1982), a brincadeira começa com o recém-nascido e a mãe. No estudo do desenvolvimento emocional do humano, o autor afirma que a construção do eu depende da qualidade da relação com a mãe. Winnicott (1982), ressalta que a figura materna representa uma importância fundamental no desenvolvimento do bebê, nos cuidados iniciais a mãe permite que o bebe constitua sua identidade, a integração do eu, que ele chama de Self. Nesta relação com a mãe surge a criatividade, para o autor é no brincar que fruem a liberdade de criação. 
No espaço potencial existente entre o bebê e a mãe, Winnicott situa a atividade lúdica, atribuindo-lhe grande valor no desenvolvimento do pensamento criativo, fundamental para a construção do conhecimento. Ao se constituir em um "espaço potencial", o brincar permite ao ser humano, no decorrer de seu desenvolvimento, lidar com suas frustrações e com a vida de maneira geral e, dessa forma, organiza sua realidade $e$ exercitar suas potencialidades (ALVES; SOMMERHADER, 2011, p.26).

Em suma, o suporte bibliográfico mostra que o brincar é fundamental para a criança na medida em que possibilita que ela se desenvolva, sendo imprescindível o resgate da brincadeira como parte integrante da infância, essencialmente no primeiro ano do ensino fundamental. Partindo dessa proposição acredita-se que a pesquisa em questão poderá favorecer relevantes discussões sobre como o jogo simbólico é praticado por crianças de seis anos de idade, bem como sua viabilidade no cotidiano do primeiro ano do ensino fundamental.

\section{ESCOLHAS METODOLÓGICAS}

A trajetória metodológica percorrida para o desenvolvimento da pesquisa exigiu a definição de teorias e procedimentos para interpretar os fatos que estão inseridos na realidade do ambiente escolar. Desse modo, quanto à forma de abordagem do problema optou-se por uma pesquisa qualitativa por se tratar de uma descrição da realidade que não pode ser mensurável, Minayo (2000).

O estudo em questão buscou compreender a realidade tendo como foco a interação da pesquisadora com as crianças no espaço educacional. Acredita-se que este processo permite uma relação de liberdade entre pesquisador e os sujeitos, oferecendo maior possibilidade de se traduzir suas representações com maior fidedignidade nas interpretações.

Como instrumento de coleta de dados foi realizada observação participante e o diário de campo foi utilizado para registrar o cotidiano da pesquisa e auxiliar na análise dos dados. Esse tipo de registro permite 0 acompanhamento do desenvolvimento do projeto e contribui significativamente na análise dos dados (COSTA, 2012).

O Diário de Campo é mais do que um simples registro de fatos ocorridos no tempo. Seu aproveitamento metodológico depende do olhar atento do pesquisador para captar detalhes do trabalho de campo e, sobretudo auxilia a memória do pesquisador para que as informações sejam analisadas com profundidade (WHITAKER, 2002, p. 151). 
Para responder a questão proposta foram realizadas quatro inserções em uma turma de vinte e quatro alunos de primeiro ano com idade média de 6 anos de uma Escola de Educação Básica (EMEB) da Rede Municipal de Ensino de Franca. Visando conhecer o contexto da pesquisa, apresentamos uma breve descrição do lócus e dos sujeitos escolhidos.

A escola localiza-se na região norte da cidade, o prédio é uma construção antiga, no qual possui três salas de aula, um pátio coberto, uma pequena quadra aberta, uma cozinha e uma sala onde funciona a secretaria, e a gestão da escola. A equipe gestora é formada pela diretora, pedagoga e coordenadora pedagógica, também trabalham nessa EMEB. seis professoras regentes de classe, duas professoras de apoio (substitutas), uma professora de Educação Física e duas professoras de Educação Musical. Além destes, compõem o quadro de funcionários: um ajudantes geral, uma secretária, uma inspetora de alunos, uma escriturária e uma merendeira..

A equipe gestora iniciou no ano de 2017 suas atividades nesta Unidade Escolar (UE), a professora que atua na sala de aula escolhida também leciona nesta UE pela primeira vez, entretanto, a maioria dos alunos frequentam a escola desde os quarto anos, pois, iniciaram na fase I da Educação Infantil. A professora que colaborou com a pesquisa possui formação em pedagogia e psicologia e é considerada pela equipe gestora uma profissional comprometida com a aprendizagem e desenvolvimento de seus alunos.

A escolha por estas crianças se deu pelo fato de estarem matriculadas no primeiro ano de ensino fundamental, período de transição da educação infantil para o ensino fundamental e devido a inexistência de momentos de brincadeiras livres registrados no plano de aula semanal da professora. Conforme relato da coordenadora, na maior parte do tempo as crianças permanecem sentadas em carteiras realizando atividades voltadas para a construção de habilidades de leitura, escrita e raciocínio lógico.

A coleta de dados foi realizada no segundo semestre de 2017 . Visando à preservação da identidade das crianças foram utilizados nomes fictícios. Para responder às inquietações levantadas, os dados coletados foram analisados tendo como referência teórica o Método de Análise de Conteúdos, considerado o mais apropriado por seu foco ser a inferência do que está por trás dos conteúdos revelados pelos sujeitos da pesquisa, é caracterizado como um conjunto de técnicas de pesquisa com o objetivo de buscar o sentido ou os sentidos de um documento (CAMPOS, 2004 p. 611).

(...) produzir inferência, em análise de conteúdo significa, não somente produzir suposições subliminares acerca de determinada mensagem, mas em embasá-las com pressupostos teóricos de diversas concepções de mundo e com as situações concretas de seus produtores ou receptores. Situação concreta que é visualizada 
segundo contexto histórico e social de sua produção e recepção. (CAMPOS, 2004, p.612)

A análise de conteúdo compreende as etapas pré-definidas, sendo elas: pré-análise, exploração do material e o tratamento e interpretação dos resultados obtidos. Esta abordagem procura compreender profundamente um fenômeno específico, trabalhando com descrições, comparações e interpretações (MINAYO, 2000).

Por meio desta abordagem, será possível responder as questões levantadas pela pesquisa e verificar como as crianças de seis anos se comportam no jogo simbólico e como essa brincadeira promove o desenvolvimento da sua imaginação.

\section{O QUE ENCONTRAMOS? CRIANÇAS CRIATIVAS!}

Apresentamos a seguir alguns resultados encontrados. Ao realizar as inserções, inicialmente observamos as crianças nos momentos de brincadeira livre com objetos diversos - como: tocos de madeira, retalhos de tecidos, tampinhas de garrafa entre outros - a fim de compreender o sentido que elas atribuem aos objetos no ato da brincadeira. Por meio desta observação verificou-se que no decorrer das semanas foram se despontando momentos de criatividade, diálogo e convivência entre as crianças por meio do jogo simbólico:

\footnotetext{
Miguel e Gabriel começaram a enfileirar os materiais, me aproximei e perguntei:

-Do que estão brincando?

Eles responderam:

- Estamos fazendo uma rampa, uma ponte de carro pra dar um pulo maior do mundo e atravessar um buracão (DIÁRIO DE CAMPO III).
}

Ao chegar à sala para a realização da primeira inserção, encontramos as crianças sentadas em duplas terminando uma atividade no livro do EMAI (Educação matemática nos anos iniciais). A professora orientou as crianças a guardarem o livro e explicou que teriam um momento de brincadeira livre no pátio, que lá encontrariam materiais para brincarem do modo que preferissem.

As crianças foram encaminhadas para o pátio, lá se depararam com variados toquinhos de madeira e tampinhas de garrafa e novamente receberam a orientação para brincarem livremente com os materiais. Foi possível constatar a surpresa e satisfação de todas as crianças e foi perceptível que aquela tinha sido a primeira situação no qual puderam explorar através de brincadeiras esse tipo de material. Imediatamente cada criança se 
posicionou perto de um objeto se dividindo em pequenos grupos de livre escolha.

Pedro disse:

- Eu adoro Brincar! ( DIÁRIO DE CAMPO I).

Essa situação ressalta a relevância do brincar como protagonista da escola, como um elemento indispensável para o desenvolvimento integral das crianças. "Apesar de inúmeros desencontros entre o jogo e educação escolar ao longo da história, não podemos negar que a ligação entre a criança e a atividade lúdica é intensa, o que torna inevitável a presença do jogo no cenário escolar." (SOMMERHALDER e ALVES, 2011, p.54).

Especificamente sobre o jogo simbólico, Piaget (1971) nos ensina que dos quatro aos sete anos, estes possuem como características: a combinação simbólica ordenada; a imitação exata do real e o simbolismo coletivo. A combinação simbólica ordenada corresponde a fase no qual se estabelece uma relativa organização na construção lúdica conforme podemos constatar na observação realizada na $3^{\text {a }}$ inserção registrada no Diário de Campo III:

\footnotetext{
As crianças estavam brincando de casinha, cada uma tinha bem definido seu papel na brincadeira, uma era a mãe e duas eram as filhas. As filhas tinham namorado, enquanto a mãe cuidava da casa, elas saíram para namorar.

Bruna me disse:

Estamos brincando de namoro. Elas saíram se afastaram e a Luíza falou:

- Irmã, por favor, sou maior que você tenho 19 anos, você tem 14. Deram uma volta pelo pátio e retornaram para a casinha (DIÁRIO DE CAMPO III).
}

De acordo a teoria de Piaget (1971) sobre a combinação simbólica ordenada, pode-se observar que existe uma relativa organização de ideias nessa brincadeira e certa coerência na conversa das crianças: a que possui maior idade já teria licença para namorar. A organização pode ser constatada na definição de papeis: a mãe cuida da casa e não namora enquanto as filhas saem para passear e namorar.

\footnotetext{
Trata-se de jogos de combinação simbólica ordenada ou com uma ordem relativa das construções lúdicas. Há um relato espontâneo do jogo, uma continuidade das ideias durante 0 diálogo. Por exemplo, uma criança diz: "Primeiro a boneca vai comer pra depois poder brincar", "Cuidado pra você não derrubar a sopa!", "Agora que você acabou pode ir.". (Friedmann,2012, p.34)
}

A imitação exata do real, a preocupação com a verossimilhança, compreende outra característica do jogo simbólico nessa faixa etária. De 
acordo com Piaget (1971, p. 176), "essas construções coordenam cada vez mais o exercício lúdico sensório motor e intelectual com o próprio símbolo".

Este estudo foi claramente verificado na $1^{\text {a }}$ inserção, conforme podemos observar nos registros do Diário de Campo I:

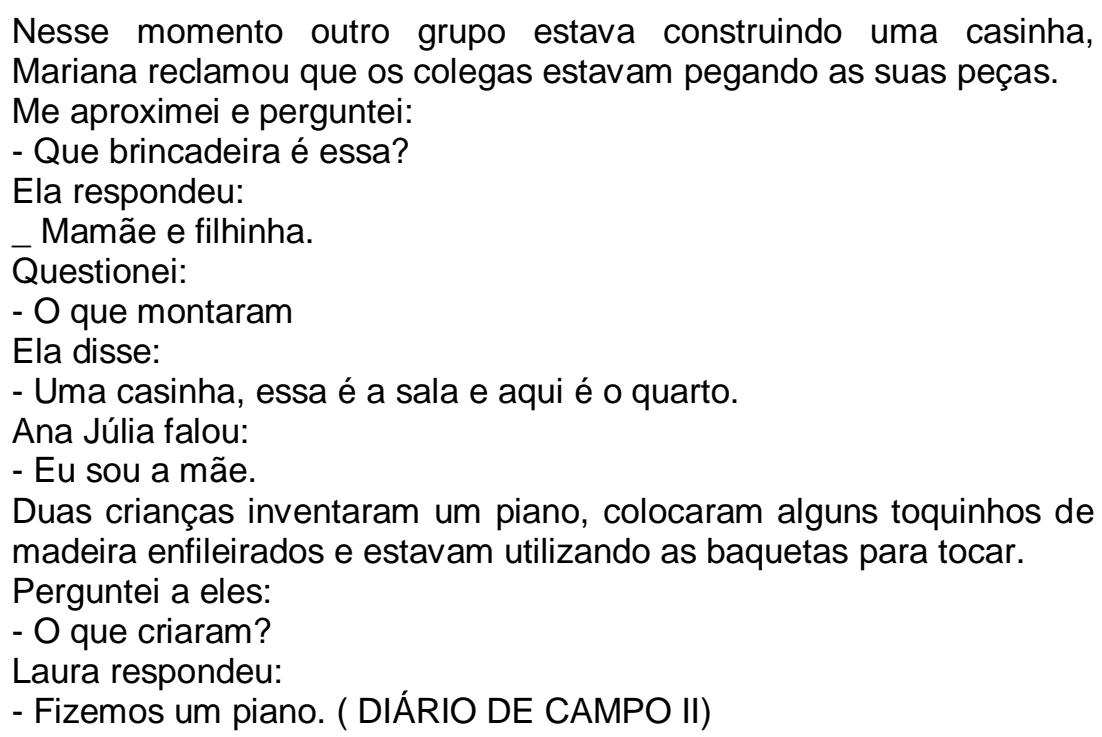

Piaget (1971) defende a ideia de que aos 6 anos as crianças se preocupam em representar a realidade, "[...] a assimilação simbólica é cada vez menos deformante e aproxima-se, pois, cada vez mais da simples reprodução imitativa. Por outras palavras, o símbolo lúdico evolui no sentido de uma simples copia do real." (PIAGET, 1971, p.177).

A casinha construída pelas crianças nessa brincadeira traz semelhanças com o real, visto que, foram construídos os cômodos de uma casa convencional devidamente mobiliada. Podemos afirmar que replicaram uma casa real.

Nesta fase inicia-se também o simbolismo coletivo, com diferenciação e ajustamento de papéis. Acontece nesse período a transição do egocentrismo para a reciprocidade. Essa ideia pode ser constatada nos registros abaixo:

A turma começou a se interessar pela brincadeira do Miguel e do Gabriel, se aproximaram deles e pediram:

- Deixa a gente brincar?

Miguel respondeu:

- Então pega mais tampinha, que eles vão voar no mundo ( carrinho que estava sendo representado por toquinhos)

Gabriel falou:

- Não! Eles vão competir qual é mais veloz. É pra saltar, tipo uma corrida.

Nesse momento outras crianças se aproximaram e começaram a brincar juntas, pegaram toquinhos representando carros e passavam pela ponte construída. 


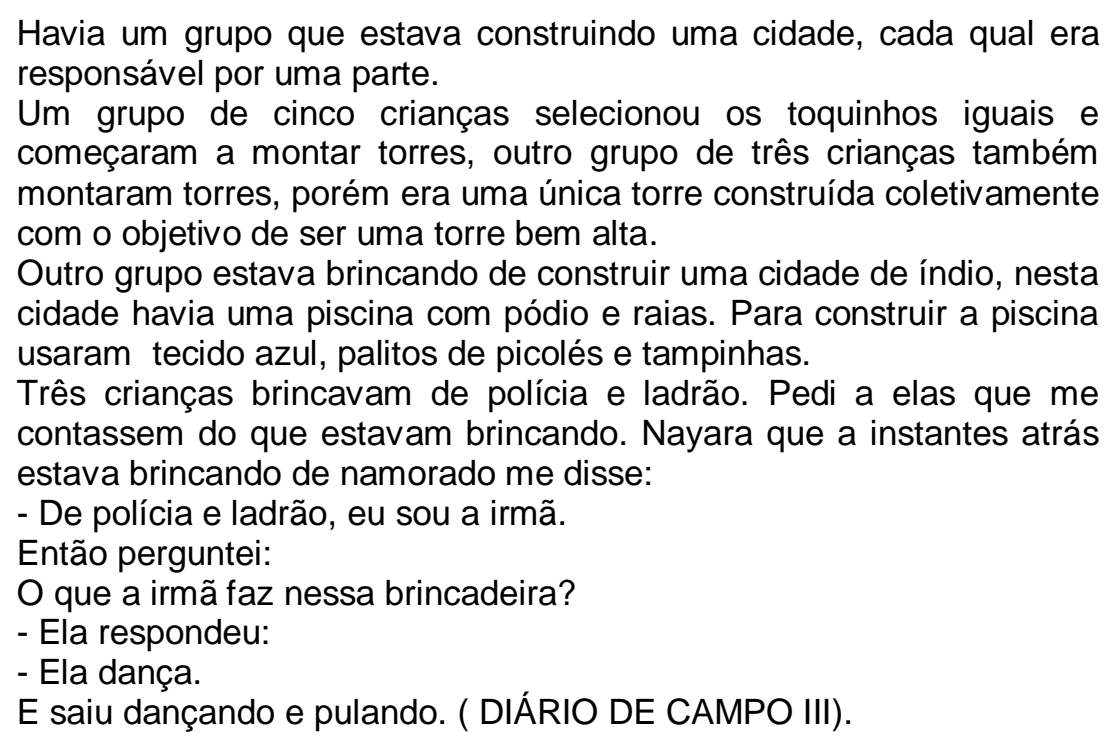

Dentro dessa ação eles assumiram papéis diferentes que se complementavam, na brincadeira percebe-se um grande progresso na socialização.

Aos seis anos também é possível observar o interesse pelo jogo de regras. "Regras supõem, necessariamente, relações sociais ou interindividuais. São uma regularidade imposta pelo grupo e sua violação constitui falta" (FRIEDMANN, 2012, p. 36). Nas inserções realizadas, muitas crianças utilizaram os materiais oferecidos para criarem jogos de regras.

A segunda inserção foi realizada em outubro de 2017, nesse dia devido a chuva, a brincadeira foi realizada dentro da sala de aula. Quando cheguei, as crianças estavam terminando uma atividade no livro didático de português. As carteiras foram organizadas de modo que as crianças puderam brincar no chão. A professora explicou que poderiam brincar do que quisessem com os materiais que foram colocados no chão (tampinha de garrafa, toquinhos e pauzinhos de madeira). As crianças iniciaram a brincadeira formando pequenos grupos conforme o interesse pelo material.

O grupo que optou pelas tampinhas inicialmente as exploraram, fizeram nariz de palhaço, brincaram aleatoriamente e depois criaram um jogo.

Me aproximei desta turma e perguntei:

- Do que estão brincando?

Alice respondeu:

- De pegar as amarelas com os pauzinhos, pra ver quem pega mais. Nesse jogo permaneceram até terminar o tempo. (DIÁRIO DE CAMPO II).

A terceira inserção também foi realizada no pátio. Neste dia, cheguei na sala e esperei as crianças terminarem um desenho. As crianças se dirigiram para o pátio e a professora disse que poderiam brincar livremente. Neste momento foram oferecidos palitos de picolés coloridos, retalhos de tecido, tampinhas e toquinhos de madeira.

Observei que muitas crianças utilizaram os materiais para criarem jogos de regras: com os tecidos foram criados amarelinhas, jogo de botão com tampinhas, competições de quem fazia a torre maior e jogo de bolas com toquinhos de madeira. 
Artur e Pedro iniciaram a brincadeira com os colegas de construir cidades, entretanto, logo perderam o interesse e começaram a correr e jogar um toquinho redondo para o ar.

Me aproximei deles e os questionei:

- Do que estão brincando?

Eles responderam:

- De jogo no ar, jogo em pé.

Os dois jogaram o tempo todo, nenhuma outra criança se interessou pelo jogo e os dois alunos brincaram entre si. ( DIÁRIO DE CAMPO III).

Mediante dados coletados podemos afirmar que as crianças de 6 anos, no momento de transição entre a fase do jogo simbólico para o jogo de regras, ainda se interessam pela brincadeira simbólica e que oferecer um ambiente propício com materiais diversificados, estimula sua criatividade. No momento da brincadeira é possível verificar como a imaginação opera nessas crianças. Conforme podemos observar no relato abaixo:

\footnotetext{
Enquanto brincavam o Lucas estava deitado no chão coberto de pauzinhos de madeira. Perguntei a ele:

- Que brincadeira é essa?

Ele respondeu:

- Cobertor de baquetas.

O barulho estava muito alto, a professora deu uma pausa na brincadeira e solicitou silêncio.

Camila e Julia disseram que estavam construindo um castelo de princesa com uma ponte.

Um grupinho de quatro meninas brincavam de casinha. Pedi a elas que me falassem um pouco sobre a brincadeira.

Alice falou:

Estamos brincando de mamãe e filhinha, a comidinha é essa aqui e apontou para os palitos de picolé que estavam embrulhados em um retalho de tecido. ( DIÁRIO DE CAMPO III).
}

A inclusão do jogo simbólico para turmas de alunos matriculados no primeiro ano de fundamental é viável por estimular a criatividade, pelo fato das crianças se interessarem por esse tipo de jogo. Entretanto, exige um planejamento com objetivos bem estabelecidos, visto que o jogo de regras, nesta idade desperta grande interesse.

Embora saibamos que os jogo de exercício e o simbólico estão presentes no jogo de regras, o planejamento de aula deve partir de observação e diagnóstico da turma para se compreender a necessidade dos alunos e a partir daí realizar uma escolha criteriosa do tipo de jogo oferecer. Deve-se considerar 0 interesse dos alunos e respeitar 0 nível de desenvolvimento das crianças. Nessa direção concordamos com Sommerhalder e Alves (2011) quando afirmam que o professor estando atento aos interesses e necessidades de sua turma, pode aproximar seus interesses didático pedagógicos ao interesse das crianças epromover aprendizagens significativas. 
Na ultima inserção realizada, foi possível verificar a necessidade de se modificar as propostas para garantir o interesse e participação dos alunos. Propositalmente a quarta inserção se deu no dia posterior à terceira inserção. Como se não tivessem interrompido a brincadeira, as crianças pegaram os mesmos materiais do dia anterior, voltaram para os mesmos lugares e retomaram as brincadeiras: brincaram de mamãe e filhinha, no qual os palitos enrolados no tecido eram as comidinhas, jogo de bola no ar, cidade de índios, polícia e ladrão e construção de torres. Passei em todos os grupos e perguntei do que estavam brincando e todos responderam a mesma coisa, que era a brincadeira do dia anterior. Perguntei:

- Laura, do que estão brincando?

Ela respondeu:

-Igual ontem de casinha uai

Percebi que a brincadeira durou pouco tempo, as crianças demonstraram desinteresse e começaram a correr. Apenas o grupo que brincava de casinha permaneceu até o fim dos trinta minutos estipulados. (DIÁRIO DE CAMPO IV).

Em suma, situações didáticas em sala de aula exigem clareza dos objetivos por parte do professor e conhecimento do estágio de desenvolvimento dos alunos para que se possa oportuniza-los à aprendizagem/desenvolvimento adequados. Nesse sentido é importante se garantir na escola espaço para o jogo que vai além do jogo educativo comumente proposto.

Piaget (1971) defende a ideia da maturação biológica, entretanto, acredita-se que ao proporcionar bons lugares para brincar, bons espaços simbólicos, boas mediações e materiais adequados pode-se favorecer 0 desenvolvimento das crianças, o que ressalta a relevância dos professores terem conhecimento sobre o desenvolvimento infantil e conhecimentos sobre as teorias que permeiam as ações lúdicas dos seus alunos.

\section{CONSIDERAÇÕES FINAIS}

Compreendemos que o brincar está diretamente relacionado com a cultura e o conhecimento, ressaltando que se trata de uma ação extremamente criadora, no qual integrando a imaginação e a fantasia a criança cria possibilidades de se expressar e de interpretar a realidade. Nesse sentido, evidenciamos a relevância de se incorporar a ação de brincar na práticas do $1^{\circ}$ ano do ensino fundamental considerando o papel da brincadeira como essencial na constituição dos processos de desenvolvimento e de aprendizagem.

Concordamos com as ideias de Sommehalder e Alves (2011), ao afirmarem que o brincar deve ser integrado nas séries iniciais do ensino fundamental nas suas variadas formas, a fim de ir além do jogo educativo, permitindo à criança brincar de, ao invés de brincar para. Aqui se entende que 
o jogo simbólico favorece a autoria da criança, estimula a fantasia e a criação, além de oportuniza-la a se expressar, aprender e desenvolver.

Corroborando essa concepção, por meio da pesquisa em questão percebemos que o jogo simbólico propiciou às crianças: tomarem decisões, escolherem, imaginarem, criarem, partilharem, expressarem suas ideias, elaborarem estratégias, tomarem iniciativa além de interagirem com os pares.

Embora Piaget (1971) alegue que a partir dos seis anos a crianças começam a demonstrar interesse por jogos de regras, por serem mais complexos e elaborados verificamos que o jogo simbólico ainda desperta interesse e fascínio nas crianças desta idade, além de ser um espaço potencial para a espontaneidade e a liberdade imaginativa.

Essa investigação nos permitiu conhecer um pouco da realidade instalada no $1^{\circ}$ ano do Ensino Fundamental da escola pesquisada, bem como possibilitou a verificação do lugar que a brincadeira tem ocupado na rotina escolar. Desse modo, afirmamos que o brincar nessa escola é reduzido como estratégia didática, e que o brincar livre é vetado por não ser considerado um instrumento do trabalho pedagógico.

Do exposto conclui-se que é emergente a necessidade de se repensar o jogo na escola, seu valor educativo deve ser considerado para se ampliar as experiências e desse modo se promover o jogo livre como um espaço de experiências que mobiliza e potencializa a aprendizagem das crianças. Esse tipo de jogo constitui em um relevante momento de aprendizagem por ser uma atividade voluntária, proporcionar liberdade e propiciar a ampliação da imaginário das crianças. Para as aprendizagens escolares a imaginação possui grande relevância na construção do conhecimento e deve estar no topo das prioridades de todas as instituições que prezam por uma educação de qualidade.

\section{REFERÊNCIAS}

BORBA, Ângela Meyer. O brincar como um modo de ser e estar no mundo. In: BEAUCHAMP, Jeanete, PAGEL, Sandra Denise, NASCIMENTO, Aricléia Ribeiro do (orgs). Ensino fundamental de nove anos: orientações para a inclusão da criança de seis anos de idade. Brasília: Ministério da Educação, Secretaria de Educação Básica, 2007. pp. 33- 45

BRASIL. Diretrizes Curriculares Nacionais para a Educação Infantil. Ministério da Educação e do Desporto. Conselho Nacional da Educação. Parecer CEB no 020/2009 aprovado em 11 de novembro de 2009. Relator: Raimundo Moacir Mendes Feitosa Disponível em: 
<http://portal.mec.gov.br/dmdocuments/parecer_ceb_22.98.pdf>. Acesso em: 01dez.2017

CAMPOS, Claudinei José Gomes. Rev. Bras Enfrem, Brasília (DF) 2004 set/out, 57 (5):611-4. Disponível em:

http://www.scielo.br/pdf/reben/v57n5/a19v57n5.pdf. Acesso em: 13 ago.2018

COSTA, Sidiney Alves. Diário de campo como dialética intersubjetiva. In: Whitaker, Dulce C. A. (org). Sociologia Rural: questões metodológicas emergentes. Presidente Venceslau: Letras à Margem, 2002.

FREUD, S. El poeta y la fantasia. In: Obras Completas: Madrid:

Editora Biblioteca Nueva Madrid, 1968, v.2, p. 1057-1061

FRIEDMANN, Adriana. O brincar na Educação Infantil: Observação, adequação e inclusão.São Paulo: Moderna,2012.

LEONTIEV, A.N. Os princípios psicológicos da brincadeira pré-escolar. In VYGOTSKY, L.S; LÚRIA,A.R;LEONTIEV, A.N. Linguagem, desenvolvimentoe aprendizagem. São Paulo:İcone, 1988-p119-142.

LIMA, Elvira Souza. Indagações sobre currículo : currículo e desenvolvimento humano - Brasília : Ministério da Educação, Secretaria de Educação Básica, 2007.

LOPES, Dulcelaine Lucia; LIMA, Helton Souto; COSTA, Sidney Alves; RIBEIRO, Vanderlei. O Diário de Campo e a memória do pesquisador. In: Whitaker, Dulce C. A. (org). Sociologia Rural: questões metodológicas emergentes. Presidente Venceslau: Letras à Margem, 2002.

MACEDO, L. de . Os jogos e sua importância na escola. Cadernos de Pesquisa, n.93,p 5-10, maio, 1995.

MINAYO, M.C. de S. Ciência, técnica e arte: o desafio da pesquisa social. In:__. (Org.). Pesquisa Social. 17ed. Rio de Janeiro: Vozes, 2000.

PIAGET, Jean. A formação do símbolo na criança: imitação,, jogo e sonho, imagem e representação. Rio de Janeiro: Zahar,1971.

SOMMERHALDER, A.; ALVES, F. D. Jogo e a educação da infância: muito prazer em aprender. 1.ed. Curitiba, PR: CRV, 2011.

VYGOTSKY, L.S. A formação social da mente. 6. ed., São Paulo: Livraria Martins Fontes, 1998.

WINNICOTT,D.W. O brincar e a realidade. Rio de Janeiro:Imago,1975 


\title{
AS POSSIBILIDADES DOS PROJETOS EDUCOMUNICATIVOS NO ENSINO FUNAMENTAL DIANTE DAS PRÁTICAS PEDAGÓGICAS
}

\author{
GONÇALVES, Gustavo Henrique \\ Mestre em Saúde e Educação - UNAERP \\ gustavonatacao@yahoo.com.br \\ TAVARES, Graciele Faine \\ Especialista em Psicopedagogia - Centro Universitário Claretiano \\ gracielefaine@gmail.com \\ CLEMENTE, Guilherme Augusto Bertelli Fernandes \\ Doutorando em Ciências - UNIFRAN \\ engenheirocivilguilherme@yahoo.com.br
}

\section{INTRODUÇÃO}

\begin{abstract}
Efetivamente, nos últimos anos a tessitura da prática docente tem vivenciado contexto uma conjuntura de diferentes sentidos e novas perspectivas educativas, na medida em que esse cenário aflora para uma demanda de profissionais que precisam (re)pensar suas práticas, contribuindo para propiciar um ambiente educacional favorável ao intercâmbio entre a Educomunicação e o desenvolvimento de Projetos de Trabalho, pois tais abordagens estão imbricadas na participação ativa do sujeito e de suas vivências educativas e comunicativas.
\end{abstract}

Visto que, o trabalho justifica-se devido a Educomunicação que é uma área do conhecimento que se caracteriza pela interface dialógica entre Comunicação e Educação, sob a perspectiva de ampliar e fortalecer ações comunicativas em ambientes educativos.

Ademais, os Projetos de Trabalho, por sua vez, tem relação prática com uma postura pedagógica do fazer docente. Com isso, é a partir dessa interconexão educativa que problematizamos o cenário atual e propomos a implementação dos Projetos Educomunicativos, constituindo-se estratégia para subsidiar a atuação docente nos espaços de ensinoaprendizagem do cotidiano escolar.

Os Projetos Educomunicativos tencionam uma aproximação entre educação e os meios de comunicação, propondo ações que objetivam uma inter-relação produtiva na interface entre comunicação e a educação. Diminuindo, assim, a distância entre esses dois âmbitos (ANDRADE; ROMANCINI, 2009, p. 8). 
Ademais, essa proposta é uma estratégia que pretende promover uma reflexão crítica na maneira de pensar e agir da comunidade escolar em que será possível fomentar a comunicação comunitária, fornecendo subsídios teórico-metodológicos para a intervenção prática do educomunicador e seu papel mediador com vistas a respeitar o ritmo, o estilo, o repertório social e cultural, as limitações e as potencialidades dos discentes.

Os projetos educomunicativos podem trazer muitos benefícios ao educando, à escola e a sua comunidade, apontando para a existência de um terreno fértil a ser semeado em muitas instituições educativas por profissionais que se orientam pela teoria do novo campo da Educomunicação (TAVARES JÚNIOR, 2007, p. 264).

Nessa perspectiva há a possibilidade de que os envolvidos com os Projetos Educomunicativos possam fortalecer ecossistemas comunicativos abertos e criativos, intervindo efetivamente na comunidade e no entorno em que transitam e assim melhorar sua própria condição de vida, pois as experiências favorecidas pelas vertentes comunicação/educação poderão indicar caminhos e possibilidades delineadas por novas propostas, novos contextos, novas alternativas, novos conhecimentos e diferentes saberes no cotidiano educativo.

no currículo escolar, a Educomunicação, por meio de seus projetos, articula os conhecimentos das matérias escolares ou áreas do conhecimento. Podemos desenvolver ações com professores de ciências, mas também com os de português, história, geografia (LIMA, 2013, p. 1).

Diante disto, é preciso reconhecer e valorizar as potencialidades de seus atores e atentar-se ao tempo/espaço de ensinar e aprender, oportunizando possibilidades educativas para além do isolamento das disciplinas, estabelecendo maior sinergia entre as diferentes áreas do conhecimento envolvidas no projeto.

Para a inserção dos Projetos Educomunicativos nos espaços educacionais, as ações e estratégias necessárias para dar voz e visibilidade a esta prática educativa somente serão possíveis se os envolvidos: docentes, discentes, comunidade escolar, pesquisadores, coordenadores e gestores estiverem comprometidos com seus objetivos, possibilitando a promoção de situações de ensino-aprendizagem inclusivas, democráticas, midiáticas e criativas (SOARES, 2011).

Portanto, a prática por meio dos Projetos deve ser planejada, administrada e avaliada em direção a um movimento dialógico, além de 
favorecer o fluxo das relações entre os membros da comunidade educativa, pois tal perspectiva requer reavaliar constantemente a atuação, a interação e as ações didático-pedagógicas.

O objetivo do trabalho é refletir as possibilidades dos projetos educomunicativos no Ensino Fundamental diante das práticas pedagógicas. Dentre os objetivos específicos, são: compreender os projetos educomunicativos nas perspectivas das práticas pedagógicas e analisar os Projetos Educomunicativos no Ensino Fundamental.

A metodologia aplicada é a revisão bibliográfica em áreas científicas, através de livros, artigos, revistas, monografias, dissertações e teses. Assim, entende-se por pesquisa bibliográfica a revisão da literatura sobre as principais teorias que norteiam o trabalho científico (GIL, 2006).

O estudo é delineado a partir do encontro conceitual entre a compreensão dos projetos educomunicativos nas perspectivas das práticas pedagógicas e posteriormente, a análise dos Projetos Educomunicativos no Ensino Fundamental.

\section{COMPREENDENDO OS PROJETOS EDUCOMUNICATIVOS NAS PERSPECTIVAS DAS PRÁTICAS PEDAGÓGICAS}

Pensando na renovação da prática pedagógica e os processos educativos o educomunicador, ciente de suas atribuições, precisa ser/estar comprometido com sua atuação, disposto a desenvolver práticas consistentes, além de domínio didático, pedagógico e tecnológico, a fim de mediar processos de autoria e garantir possibilidades de aprendizagem nos diferentes ecossistemas.

Conforme Soares (2011) esses ecossistemas se comunicam e constituem o entorno que nos envolve, caracterizado por ser "difuso" e "descentrado". Difuso porque formando uma mistura de linguagens e de saberes que circulam por diversos dispositivos midiáticos intrinsecamente interconectados; descentrado porque os dispositivos midiáticos que 0 conformam vão além dos meios que tradicionalmente vêm servindo à educação, a saber: escola e livros.

Assim, para atuar nesse ecossistema comunicativo espera-se que o educomunicador, como mediador de Projetos Educomunicativos, considere o conhecimento prévio do discente e da turma, respeitando a individualidade e o ritmo de ensino-aprendizagem, construindo percursos mais significativos e planejando ações educativas que possam melhorar os fluxos de comunicação humana. 
No entanto, é preciso romper com antigas crenças e acompanhar as transformações advindas da inserção das tecnologias no cotidiano escolar. Quanto ao aspecto didático, o enfoque das tecnologias refere-se aos métodos, técnicas e processos de ensino-aprendizagem destinados a colocar em prática as diretrizes educacionais e curriculares. Já do ponto de vista pedagógico, as transformações não devem ser baseadas exclusivamente na inserção desses recursos em sala de aula, sobretudo em sua utilização de forma sistematizada com o projeto (SOARES, 2011).

Todavia, na gestão dos Projetos Educomunicativos, a instituição escolar, como ecossistema que emerge da relação dialógica de vários outros sistemas, deve promover o fluxo comunicacional, analisar a realidade social e cultural, identificar as demandas e reais necessidades de seus atores, incentivar a criatividade, apoiar o educomunicador no desenvolvimento de práticas de intervenção que atendam às expectativas dos envolvidos, além de promover a mobilidade no processo e produção dos Projetos, no contexto da sala de aula, nos laboratórios de informática, nas salas de leitura, nos estúdios, dentre outros espaços educativos, especialmente porque a relação desses recursos com as possibilidades comunicativas são formas de promover e tornar público o que é produzido na/e para a escola, dentro e fora dela, respeitando o currículo, o repertório e a pluralidade cultural da comunidade escolar.

Ao passo que, por tratar-se de um agente de mudanças, o educomunicador deverá incorporar o uso desses recursos de forma dinâmica e elaborar uma intervenção que busque atingir objetivos de ensino-aprendizagem propostos nos Projetos, além de intervir para sistematizar tais inovações às suas ações (SOARES, 2011).

Em adição, nas suas atribuições deve elaborar práticas educacionais organizadas e mediadas, além de promover o desenvolvimento de ações interdisciplinares, especialmente, porque o trabalho em equipe, com base em Projetos Educomunicativos, requer ampliar o diálogo na escola, confrontar opiniões, estimular a interação entre os diferentes atores, mediar as relações interpessoais que resultem em uma prática consistente, priorizando a articulação com as diferentes áreas do conhecimento e programas desenvolvidos pela escola.

Diante da relação à organização curricular, os Projetos Educomunicativos envolvidos com a formação integral dos sujeitos propõem um diálogo que transcende a vertente disciplinar para uma perspectiva interdisciplinar. Essa transversalidade entre as temáticas deve ser investigada, problematizada e contextualizada, não restringindo-se apenas à sala de aula (LIMA, 2013).

Acrescentando que, a ideia é analisar e apreciar os projetos educomunicativos como proposta para promover práticas colaborativas, cooperativas e compartilhadas que fomentem o conhecimento e experiência no 
cotidiano escolar no âmbito do Ensino Fundamental. Sobretudo, para sua efetivação é preciso ampliar os canais de comunicação, intercalar as diferentes linguagens e acompanhar as transformações tecnológicas, potencializando a prática pedagógica de forma interdisciplinar.

Figura 1 - Elaboração dos Projetos Educomunicação.

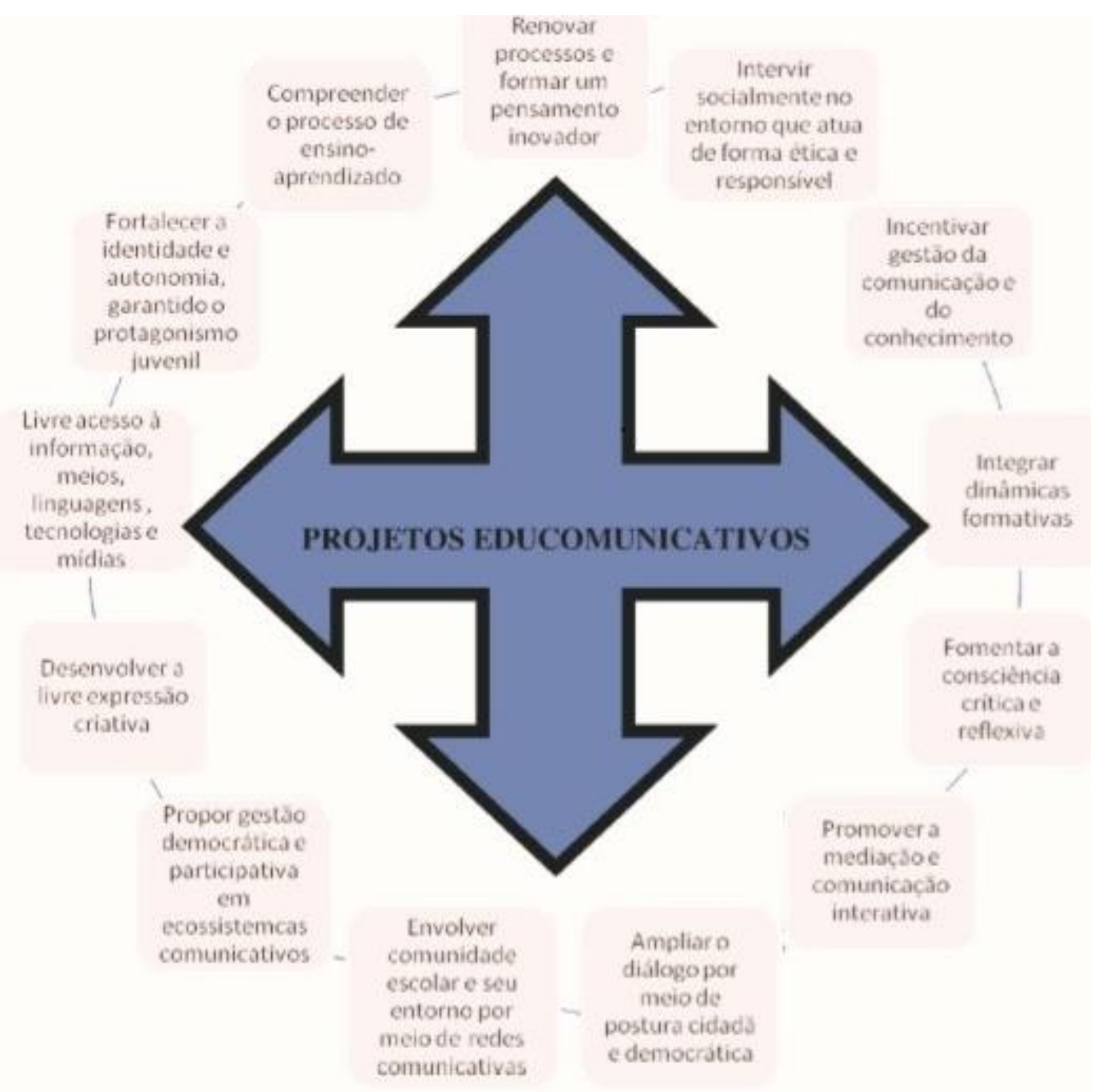

Fonte: (SOARES, 2011, p. 2).

Nessa perspectiva, a partir do envolvimento com a transformação social, o discente compreende o processo de aprender, pois aprende fazendo, levanta hipóteses, pesquisa, investiga, cria, faz descobertas, dialoga com seus pares, se expressa, desenvolve habilidades e competências educomunicativas, amplia sua capacidade de expressão, utiliza as tecnologias para mediar conflitos e estabelece relações que incentivam novas (re)construções. 
De fato, para dar início aos Projetos Educomunicativos no cotidiano escolar é preciso primeiramente abertura para apresentar e discutir coletivamente os conceitos que orientam a Educomunicação e os Projetos de Trabalho, objetivando compreender as possibilidades que adentram o espaço escolar, pois todos os agentes estarão cientes do seu papel, de suas ações e intencionalmente envolvidos com o processo de implementação dos Projetos Educomunicativos, propondo que crianças e jovens:

se apoderem das linguagens midiáticas, ao fazer uso coletivo e solidário dos recursos da comunicação, tanto para aprofundar seus conhecimentos quanto para desenhar estratégias de transformação das condições de vida à sua volta, mediante Projetos Educomunicativos legitimados por criatividade e coerência epistemológica (SOARES, 2011, p. 19).

Nesse sentido, o contexto educomunicativo não se trata de educar usando o instrumento da comunicação, mas de que a própria comunicação se converta na vértebra dos processos educativos: educar pela comunicação e não para a comunicação, ressituados a partir de um projeto pedagógico mais amplo e que esteja em consonância com os objetivos educacionais.

Some-se a isto, para a organização do trabalho pedagógico, o educomunicador deve assumir papel protagônico no processo (SOARES, 2011), a ele cabe elaborar um roteiro de atuação, que deve ser visto não como uma fórmula pronta e acabada, mas um canal de comunicação que merece atenção ao destacar-se como elemento norteador do seu trabalho.

É preciso organizar o tempo e espaço escolar, considerando que o Projeto Educomunicativo e todas as suas vertentes de atuação devem ser delineadas por arranjos abertos, criativos e participativos, ou seja, o educomunicador, os discentes, a família, a comunidade escolar e a sociedade são fundamentais em todo o processo.

Ressaltando que, o educomunicador também poderá investir em aulas exploratórias e participativas, permitindo com que o processo educativo seja construído a partir das diversas possibilidades de ensino-aprendizagem, transformando diálogos unilaterais em bilaterais, relacionando ensino e aprendizagem, contemplando teorias e práticas, dando voz ativa aos envolvidos, fomentando a leitura crítica, potencializando o ecossistema comunicativo que dá base à escola, além de abrir espaços para as diferentes linguagens, incentivar o uso de instrumentos de comunicação, mídias e recursos tecnológicos (SOARES, 2011). 
No entanto, é preciso considerar que as tecnologias e as mídias são aliadas do trabalho docente, e se bem (re)utilizadas podem contribuir para estabelecer diferentes e importantes conexões ao longo do Projeto.

Nesse caminho, o Educomunicador é orientador e facilitador de práticas interdisciplinares, constitui-se mediador na busca da informação e sua relação com a construção do conhecimento, disposto a contextualizar a situação-problema, ampliar conceitos de modo que dialogue com o universo cultural das crianças e jovens, considerando o entorno e a comunidade em que vivem (LIMA, 2013).

Nos Projetos Educomunicativos, a autonomia promove uma leitura crítica do mundo, visto que a pesquisa individual e o engajamento pessoal abrem precedentes para ampliar o repertório de modo que os envolvidos tenham consciência reflexiva do percurso de ensino-aprendizagem, garantindo a livre expressão, além de estabelecer voz ativa diante das diversas situações que se apresentem, pois ao estudar, pesquisar, explorar, os estudantes estarão diante de desdobramentos que poderão contribuir para uma ampla discussão em sala de aula. Ao pesquisar individualmente e percorrer caminhos diferentes terão flexibilidade para tecer sua própria rede de significados, esse processo refere-se à

\begin{abstract}
capacidade de saber fazer escolhas e de posicionar-se, elaborar projetos pessoais e participar enunciativa e cooperativamente de projetos coletivos, ter discernimento, organizar-se em função de metas eleitas, governar-se, participar da gestão de ações coletivas, estabelecer critérios e eleger princípios éticos (BRASIL, 2011, p. 94).
\end{abstract}

Diante disto, essa perspectiva ativa também poderá contribuir para elevar a autoestima das crianças e jovens, ampliando a disposição para buscar posicionamento no mercado de trabalho, buscar a resolução de problemas, elevar a capacidade criadora e um efetivo envolvimento em todas as fases do desenvolvimento do Projeto.

$\mathrm{Na}$ proposta de trabalho em equipe também é apontada nos aportes metodológicos de Dewey (1979) e Hernández (1998) ao defender e valorizar a perspectiva de Projetos. A culminância é o momento de apresentar a produção final, fase em que abre-se espaço para expor criações, comunicar descobertas, compartilhar dificuldades, sem focar exclusivamente no produto. O importante é abrir possibilidades de apresentar o processo à comunidade, pois ao compartilhar o Projeto o desafio é

pensar a mudança para uma educação cidadã, tendo em conta todas as partes, desde a família, o ambiente, os profissionais da educação e da direção da escola, aliando desenvolvimento cultural e econômico 
em vista de melhores condições para o ecossistema educacional e social (CORAZZA, 2011, p. 14).

Nessas possibilidades dos novos desafios da sociedade contemporânea, a Educomunicação e a implementação de Projetos Educomunicativos apresentam-se como cenário e possibilidade para nortear a prática pedagógica no cotidiano escolar, potencializando a construção de conhecimentos interdisciplinares em sala de aula, além de contribuir para inaugurar posturas teóricas e práticas que se situam para além das tradicionais paredes paradigmáticas, reconceitualizando a relação entre comunicação e educação e direcionando-a para educação cidadã emancipatória.

\subsection{Analisando os Projetos Educomunicativos no Ensino Fundamental}

Nas duas últimas décadas os bancos de teses e dissertações das instituições de ensino superior têm apresentado um crescente número de pesquisas que abordam produções científicas e acadêmicas sobre 0 fortalecimento e solidificação da Educomunicação como área do conhecimento.

Como esclarece Soares (2011), a Educomunicação apesar de visível, encontra-se em processo de identificação e reconhecimento, no entanto, a consolidação do conceito e seu reconhecimento pela academia e, agora pelas políticas públicas brasileiras, não fizeram mais que constatar um processo em andamento e que tem avançado de forma considerável.

No refinar deste estudo, foi possível constatar que a última década tem evidenciando um crescente aporte teórico-metodológico sobre o conceito, trajetória e abrangência da Educomunicação, incluindo a implementação de Projetos Educomunicativos nos espaços educativos do ensino fundamental.

De acordo com Pinheiro (2013) estudos apontam que a prática educomunicativa no Ensino Fundamental vem sendo consolidada e legitimada por autores de referência nacional e internacional, e isso não se limita ao espaço universitário, especialmente, porque vem conquistando espaço, novas expectativas e outras áreas do conhecimento.

Partindo dos últimos vinte anos, a Educomunicação vem conseguindo densidade própria e avançando consideravelmente para os estados brasileiros, o que demanda em um (re)pensar de sua inserção política.

Diante da legitimidade da Educomunicação no Brasil, em termos de políticas públicas, Próspero (2013) traz contribuições, na qual enfatiza o paradigma educomunicativo, como prática social que contribui para mobilizar 
sistemas formais de ensino e fortalecer o protagonismo infanto-juvenil dos discentes, dentre outras propostas que a partir da abordagem educomunicativa têm:

impacto direto num processo educativo que visa promover a educação integral: aumento de repertório cultural; desenvolvimento de competências comunicativas; aprendizagem de habilidade de leitura e escrita e maior compreensão pela comunidade local (PRÓSPERO, 2013, p. 205).

A efetivação de tal proposta dialógica no Ensino Fundamental é preciso construir um perfil ativo, reflexivo e discursivo, incentivando a formação, a mediação e abrindo possibilidades para novas propostas pedagógicas e interdisciplinares.

Para Moreira (2012) a Educomunicação no Ensino Fundamental revela uma riqueza empírica e teórica que torna a reflexão epistemológica acerca do campo uma exigência, uma necessidade premente, nesse aspecto sua implementação vem ocorrendo por profissionais formados e atuantes em suas áreas de origem, o que requer um (re)pensar constante sobre seu perfil, sua formação e sua atuação.

Siqueira (2009), traz reflexões educomunicativas no Ensino Fundamental a partir das possibilidades e limites da formação continuada docente, com o propósito de promover uma ação transformadora em suas práticas de forma crítica e dialógica, a esse compromisso formativo inclui-se a inserção e incorporação dos meios de comunicação e linguagens no cotidiano escolar.

Conforme Siqueira (2009) a Educomunicação no Ensino Fundamental está situada no campo que atravessa as áreas da Comunicação e da Educação, na medida em que a pesquisa tem compromisso ético e político com a promoção da autonomia dos sujeitos envolvidos com seu próprio processo educativo, apoiando-se na perspectiva da reflexibilidade, profissionalização e abordagem social da formação docente.

A autora aponta que o projeto favorece a conquista da autonomia pelo educador, não como indivíduo isolado, mas como rede articulada, fortalecendo-o na sistematização, defesa e legitimação de seus Projetos Educomunicativos.

Diante das discussões encontrados, os Projetos Educomunicativos no cotidiano escolar é preciso primeiramente abertura para apresentar e discutir coletivamente os conceitos que orientam a Educomunicação e os Projetos de Trabalho, objetivando compreender as possibilidades que adentram o espaço escolar, pois todos os agentes estarão 
cientes do seu papel, de suas ações e intencionalmente envolvidos com o processo de implementação dos Projetos Educomunicativos, propondo que aos educandos do Ensino Fundamental que se apoderem das linguagens midiáticas.

Dessa forma, acredita-se que as ações propositivas a serem desenvolvidas no cotidiano escolar devem ser construídas com objetivos e metas bem definidas, os processos devem ser sistematizados, participativos e dialógicos, mantendo o potencial educativo dos ecossistemas comunicativos, assim cada uma dessas áreas com suas características e especificidades podem ser assumidas de forma interdisciplinar, que em uma vertente didáticopedagógica permitirá a todos os envolvidos atuarem de forma organizada, intervindo no sentido de promover a consciência crítica, além de fortalecer a perspectiva dos Projetos Educomunicativos do Ensino Fundamental.

Com base nos caminhos pontuados anteriormente é possível destacar que os Projetos Educomunicativos empreendidos nesses estudos puderam contribuir com a formação de sujeitos ativos e participativos, promovendo e facilitando ações educomunicativas.

\section{CONSIDERAÇÕES FINAIS}

Sinceramente, o efetivo diálogo entre Educomunicação e Projetos de Trabalho no cotidiano escolar do Ensino Fundamental, apresenta uma gama de possibilidades de atuação que podem concretizar-se através da implementação dos Projetos Educomunicativos e suas áreas de intervenção.

Com isso, a Educomunicação apresenta uma filosofia e uma prática da educação e da comunicação, baseada no diálogo e na participação, que não exigem somente as tecnologias, como também uma mudança de atitudes e de concepção, isto porque postura requer ir além do isolamento entre temas e disciplinas, requer sobretudo uma difusão ampla de saberes e novos conhecimentos.

Dessa forma, a construção desse ecossistema educomunicativo na escola demanda clareza conceitual, objetivos, metas, planejamento e avaliação das ações, requer sobretudo uma prática pedagógica focada na interdisciplinaridade e na dialogicidade educomunicativa e uma sugestão é a iniciação no Ensino Fundamental com esta possibilidade de projetos educomunicativos diante das práticas pedagógicas.

Então, no intuito de implementar a prática formativa na construção de saberes para atuar na/e para a Educomunicação, é fundamental que o educomunicador esteja comprometido em aprofundar seus conhecimentos teóricos metodológicos, participando ativamente de contextos de formação 
continuada, seja por meio de palestras, oficinas, congressos, seminários, ou através de cursos extensão, aperfeiçoamento ou pós-graduação.

\section{REFERÊNCIAS}

ANDRADE, L.; ROMANCINI, R. Educomunicação e Pedagogia de Projetos: abordagens e convergências. In Intercom, XXXII Congresso Brasileiro de Ciências da Comunicação. Curitiba. 2009. Disponível em: http://www.intercom.org.br/papers/nacionais/2009/resumos/R4-2730-2.pdf.

Acesso em: 05 ago. 2019.

BRASIL. Secretaria de Educação Fundamental. Parâmetros Curriculares Nacionais: introdução. MEC/SEF. 3ª ed. Brasília: A secretaria, 2011.

CORAZZA, H. Discurso da qualidade na educação e invisibilidade do professor na revista Veja. Universidade de São Paulo. ECA/USP. 2011. Disponível em: http://www.intercom.org.br/papers/nacionais/2011/resumos/R6-0571-1.pdf.

Acesso em: 10 ago. 2019.

DEWEY, J. Como pensamos. 4ª ed. Coleção atualidades pedagógicas, v. 2, Nacional: Rio de Janeiro, 1979.

GIL, A. Métodos e técnicas de pesquisa social. 5 ed. São Paulo: Atlas, 2006.

HERNÁNDEZ, F. Transgressão e Mudança na Educação: os Projetos de Trabalho. Tradução Jussara Haubert Rodrigues. Porto Alegre: Artes Médicas Sul, 1998.

LIMA, C. A educomunicação é uma ponte entre as pessoas e o conhecimento. Centro de Referências em Educação Integral. 2013. Entrevista concedida a Jéssica Morais. Disponível em: http://educacaointegral.org.br/reportagens/aeducomunicacao-e-uma-ponte-entre-as-pessoas-e-oconhecimento-dizespecialista. Acesso em: 10 ago. 2019.

MOREIRA, A. O perfil e a atuação dos/as comunicadores/as em projetos de Educomunicação dos movimentos populares. Dissertação. Universidade Federal do Paraná. 2012. Disponível em: http://bdtd.ibict.br/vufind/Record/UFPR_445b5c907c546eb9b8a703054d960189 . Acesso em: 11 ago. 2019. 
PINHEIRO, R. A Educomunicação nos centros de pesquisa do país: Um mapeamento da produção acadêmica com ênfase à contribuição da ECA/USP na construção do campo. São Paulo. 2013. Tese. Disponível em: https://sucupira.capes.gov.br/sucupira/public/consultas/coleta/trabalhoConclusa o/viewTrabalhoConclu sao.jsf?popup=true\&id_trabalho=132786. Acesso em: 13 ago. 2019.

PRÓSPERO, D. Educomunicação e políticas públicas: os desafios e as contribuições para o Programa Mais Educação. Dissertação. ECA-USP. São Paulo. 2013. Disponível em: https://sucupira.capes.gov.br/sucupira/public/consultas/coleta/trabalhoConclusa o/viewTrabalhoConclu sao.jsf?popup=true\&id_trabalho=132786. Acesso em: 15 ago. 2019.

SIQUEIRA, J. Quem educará os educadores? A Educomunicação e a formação de docentes em serviço. Dissertação. Escola de Comunicação e Artes da USP. São Paulo. 2009. Disponível em: http://bdtd.ibict.br/vufind/Record/USP_7d95cbdc8d4f370d55e791cb29c0cc41. Acesso em: 03 ago. 2019.

SOARES, I. Educomunicação: o conceito, o profissional, a aplicação. $2^{\mathrm{a}}$ ed. Paulinas: São Paulo, 2011.

TAVARES JUNIOR, R. Educomunicação e expressão comunicativa: a produção radiofônica de crianças e jovens no projeto educom.radio. Dissertação. ECA/USP, São Paulo. 2007. Disponível em: http://www.teses.usp.br/teses/disponiveis/27/27154/tde-23072009-203453/ptbr.php. Acesso em: 16 ago. 2019. 


\title{
BRINQUEDOTECA UNIVERSITÁRIA E AS POSSIBILIDADES NA FORMAÇÃO DISCENTE CURSO DE PEDAGOGIA
}

\author{
SILVA, Katiucia \\ Universidade de Franca \\ CONTI, Carmen Lúcia Tozzi Mendonça \\ Universidade de Franca
}

\section{INTRODUÇÃO}

A brinquedoteca, é um espaço capaz de proporcionar e permitir o brincar com objetividade e significado, possibilita através de objetos, brincadeiras e jogos o desenvolvimento infantil e aquisições das dimensões lúdicas organizadas.

A ludicidade é uma necessidade do ser humano, podendo ser definida em prazer em realizar determinadas atividades, e é experimentada em qualquer idade, possibilita o desenvolvimento de potencialidades.

Geralmente a ludicidade está relacionada ao brincar, seja ele espontâneo ou direcionado e, em grande parte as crianças vivenciam suas experiências e adquiri habilidades através desta, que auxilia no seu desenvolvimento integral.

Segundo Kishimoto (2010, p.1), para a criança, o brincar é a atividade principal do dia-a- dia, é importante porque dá a ela o poder de tomar decisões, expressar sentimentos e valores, conhecer a si, aos outros e o mundo, de repetir ações prazerosas, de partilhar, expressar sua individualidade e identidade por meio de diferentes linguagens, de usar o corpo, os sentidos, os movimentos, de solucionar problemas e criar, ao brincar, a criança experimenta o poder de explorar o mundo dos objetos, das pessoas, da natureza e da cultura, para compreendê-lo e expressá-lo por meio de variadas linguagens, mas é no plano da imaginação que o brincar se destaca pela mobilização dos significados. Enfim, sua importância se relaciona com a cultura da infância, que coloca a brincadeira como ferramenta para a criança se expressar, aprender e se desenvolver.

O brincar e o jogar são as principais atividades relacionadas a ludicidade, por serem formas de comunicação e expressão, nativas desde o nascimento, isto porque o homem utiliza a imaginação e a fantasia para interagir com a realidade que o cerca e para a produção de novas possibilidades. 
Na infância, o jogo e a brincadeira são uma ação espontânea e prazerosa, a criança constrói a sua cultura lúdica brincando.

A cultura lúdica pode ser apresentada como a observação de uma realidade complexa em transformação desta em brincadeiras, ou seja é uma produção do próprio sujeito.

Para Brougère (1998, p.8), alguns dos fatores podem influenciar nessa construção: hábitos sociais, condições climáticas, condições especiais, idade, sexo, ambiente em que se encontra a criança e a concepção de infância.

Devemos também levar em consideração as diferentes linguagens a que temos acesso, bem como os ambientes virtuais e os jogos tecnológicos.

As diretrizes curriculares nacionais para a educação (2009, p.17), aponta o brincar e a ludicidade como uma atividade muito importante para a criança pequena, pois possibilita a criança a oportunidade de imitar 0 conhecido e para construir o novo, conforme ela reconstrói o cenário necessário para que sua fantasia se aproxime ou se distancie da realidade vivida, assumindo personagens e transformando objetos pelo uso que deles faz. Ainda de acordo com as diretrizes, na história cotidiana das interações com diferentes parceiros, vão sendo construídas significações compartilhadas, a partir das quais a criança aprende como agir ou resistir aos valores e normas da cultura de seu ambiente, bem como a oportunidade de se desenvolverem como pessoa.

Diante da importância do brincar e do jogar, a brinquedoteca passa a ser, então, um espaço de suma importância para o desenvolvimento da criança, em que, de forma organizada ou livre, o ato de brincar torna-se significativo.

As Brinquedotecas podem ser disponibilizadas para uso em diversos espaços, Segundo Kishimoto (2010), podem ser classificadas de acordo com algumas características, quanto ao tipo e sua função, que determinam qual o objetivo. De acordo com Diniz (2018, p. 5) as classificações das brinquedotecas são: creches e escolas Infantis com finalidades pedagógicas, brinquedotecas de comunidades ou bairros com a finalidade de divertimento e espaços para brincar, são mantidas por associações, prefeituras ou entidades filantrópicas, brinquedotecas para crianças portadoras de deficiências físicas ou mentais, com a finalidade de divertir e colaborar no desenvolvimento das crianças, brinquedotecas em hospitais, ajudam as crianças a descontraírem durante o período de tratamento, brinquedotecas em universidades, com a finalidade de formação de recursos humanos, projetos, 
pesquisa e atendimento à comunidade, brinquedotecas circulantes, em ônibus, caminhonetes etc., para atender crianças em diferentes locais.

Desta forma, o objetivo deste, é ampliar uma fundamentação teorica da dimensão da brinquedoteca na formação discente e destacar a qualidade da formação dos que atenderão a primeira etapa da educação básica, em especial em jogos e brincadeiras, tão quanto importante as demais.

\section{OBJETIVOS}

Analisar e compreender a dimensão da brinquedoteca na formação discente no curso de Pedagogia, no que abrange brincadeiras, jogos e ludicidade.

\section{BRINQUEDOTECA NA FORMAÇAO DISCENTE}

A brinquedoteca universitária contribui na formação discente, porporcionando conhecimento e informações necessárias para que os mesmos saibam utilizar jogos e brincadeiras na educação, com objetividade e, possibilitar competências para reconhecer o desenvolvimento infantil e as suas necessidades, visto que os discentes serão mediadores no processo ensino apendizagem e essenciais para o desenvolvimento de diferentes brincadeiras e jogos na escola, com fins educativos e também recreativos.

\footnotetext{
O brincar, assim como a arte, o movimento, a expressão plástica, verbal e musical, pode ser considerado como uma linguagem, através da qual as crianças se comunicam, entre si e com os adultos. O brincar é um sistema de signos que representa, de forma inconsciente, a vida real, sob o olhar daquele que brinca (o jogo simbólico, por exemplo); o brinquedo ou os objetos utilizados no jogo, representam uma ponte, um meio de comunicação, a partir do qual designa-se uma realidade mais complexa. (FRIEDMANN, 2014, p.95)
}

Uma das várias possiblidades trabalhadas na brinquedoteca durante a formação discente, são as brincadeiras e jogos, que contribuem para o desenvolvimento e manutenção da cultura lúdica.

A investigação e pesquisa da formação dos discente em pedagogia aprofundada na área de brincadeiras e ludicidade é uma oportunidade para estudo e contribuição para informação e conhecimento da 
importância do brincar no desenvolvimento da criança, e está fundamentado na lei 13.257 de 8 março de 2016.

A política pública por meio do estatuto da primeira infância, a relevância do brincar no desenvolvimento infantil, através do Art. 50 constituem, a cultura, o brincar e o lazer, e art. 17. a União, os Estados, o Distrito Federal e os Municípios deverão organizar e estimular a criação de espaços lúdicos que propiciem o bem-estar, o brincar e o exercício da criatividade em locais públicos e privados onde haja circulação de crianças, bem como a oportunidade de ambientes livres e seguros em suas comunidades.

Segundo Santos (2015, p.15), os discentes, futuros o professores, deverão saber escolher os brinquedos certos para cada faixa etária, levando em conta para quem é destinado esse brinquedo, para que ele proporcione o desenvolvimento, o aprendizado e a oportunidade por intermédio do brincar. É necessário, então, haver uma reflexão sobre o papel do professor na Educação Infantil, pois é nessa etapa que o brinquedo tem um papel tão importante. É preciso questionar se o professor sabe, realmente, a relação do brinquedo com a criança, consciente do que este pode proporcionar, ou se sua prática repete as tendências e os ensinamentos dos jardins de infância nos quais a brincadeira era vista somente como uma atividade livre e de busca pelo prazer.

\begin{abstract}
As instituições de Educação Infantil precisam organizar um cotidiano de situações agradáveis, estimulantes, que desafiem o que cada criança e seu grupo de crianças já sabem sem ameaçar sua autoestima nem promover competitividade, ampliando as possibilidades infantis de cuidar e ser cuidada, de se expressar, comunicar e criar, de organizar pensamentos e idéias, de conviver, brincar e trabalhar em grupo, de ter iniciativa e buscar soluções para os problemas e conflitos que se apresentam às mais diferentes idades, e Ihes possibilitem apropriar-se de diferentes linguagens e saberes que circulam em nossa sociedade, selecionados pelo valor formativo que possuem em relação aos objetivos definidos em seu Projeto Político-Pedagógico. (Brasil, 2009)
\end{abstract}

A Base Nacional Comum Curricular (BNCC) para a Educação Infantil reforçam a ideia da importância de se oferecer para as crianças atividades voltadas para a brincadeira ou para as aprendizagens que ocorrem por meio de ação em grupo, pois essa possibilidade amplia o espaço da criança para exercer sua capacidade de criação.

Assim, a brinquedoteca universitária, organizada através das ações pedagógicas, como eventos, oficinas, laboratórios e elaboração de material pedagógico, contribui para a fomação discente, pois para desenvolver as atividades é necessário um estudo prévio, das idades, brincadeiras e jogos adequados. 


\section{PRÁTICAS PEDAGÓGICAS DA BRINQUEDOTECA UNIVERSITÁRIA}

A prática pedagógica da brinquedoteca universitária, dentro de uma instiuição de ensino superior, envolve planejamento e os processos pelos quais será possível garantir 0 acesso a uma aprendizagem significativa, estabelencendo uma relação teoria e prática.

As universidades, principalmente nas ciências humanas, buscam cumprir as metas de ensino, pesquisa e extensão e a capacitação de recursos humanos através do lúdico. Nesses cursos a Brinquedoteca é encarada como um laboratório onde professores e alunos do Ensino Superior dedicam-se à exploração do brinquedo e do jogo em termos de pesquisa e de busca de alternativas que possibilitem vivências, novos métodos, estudos, observações, realizações de estágios e divulgação para a comunidade (SANTOS, 2000, p. 59).

Para uma prática pedagógica significativa por meio das ações da brinquedoteca, há que se levar em consideração a estrutura e organização, tanto de espaço físico como de recursos humanos, outro fator relevante é participação dos alunos, em uma questão fundamental que é o envolvimento acadêmico.

As ações da brinquedoteca estimulam uma atuação crítica reflevixa, baseada em uma aprendizagem ativa e também com uma perspectiva de desenvolvimento de competências, habilidades e atitudes.

De forma objetiva, as práticas pedagógicas desenvolvidas em uma brinquedoteca universitária, ocorrem através de contrbuições do desenvolvimento das capacidades discente, na planejamento e organização de diferentes práticas educativas, que envolvam ensino aprendizagem e forma lúdica. Ao mesmo tempo que, produz um novo conhecimento, o que estabelece a relação com extensão e e pesquisa dentro de uma universidade, em especial, quando colabora para a comunidade interna e externa.

Como processo formativo, acreditamos que a Brinquedoteca Universitária contribui na formação do educador brinquedista. $O$ acadêmico que, ao longo do Curso de Pedagogia, participa do processo formativo Brinquedoteca Universitária, por meio de Grupos de Estudos, atividades extracurriculares na comunidade e desenvolve pesquisa, garante a formação de brinquedista. (ROEDER, 2008, p.5).

A brinquedoteca enquanto prática pedagógica e pocesso formativo, poderá ser aplicada em atividades discente em diferentes formatos, 
em específico, há um destaque atual para os formatos itinerante, ambiente virtual de aprendizagem e estrutura física, disponibilizada através de um espaço organizado.

No formato itinerante, não há um espaço fixo físico destinado as práticas e ações das brinquedotecas, o ponto positivo deste formato é que não há limitação e barreiras físicas, visto que é possível desenvolver atendimentos, ações e atividades em diversos lugares e situações, tanto na questão de recursos físicos ou humanos.

O ambiente virtual de aprendizagem, também é considerado uma prática pedagógica, pois através dos módulos, é contextualizado a brinquedoteca e suas formas, com sugestões e demonstrações de atividades, recursos, planejamento e organização.

A brinquedoteca organizada através de um espaço físico, possui além da estratégia pedagógica, a possibilidade de visualizar um espaço e um contexto pedagógicos de jogos, brinquedos e ludicidade.

É importante destacar, que um curso de pedagogia, que proporciona uma brinquedoteca na formação dos seus discentes, é um diferencial de qualidade, em especial na formação de brinquedistas, essenciais na organização e atuação em brinquedotecas, nos seus diferentes formatos.

Assim, a prática pedagógica da brinquedoteca universitária, é também uma prática educativa e transformadora, com foco no aperfeiçoamente profissional constante e ressignifcação do brincar, com objetividade e produção de conhecimento.

\section{CONSIDERAÇÕES}

A brinquedoteca é capaz de ofertar uma contribuição significativa na formação dos discentes do curso de pedagogia, com objetivos e procedimentos para promover o brincar, o desenvolvimento e aprendizagem através de um espaço lúdico e prazeroso, em especial fundamentado em com conhecimentos em desenvolvimento humano, jogos e brincadeiras. Ao mesmo tempo, essa mesma brinquedoteca dentro da Universidade, ganha característica de laborátorio de pesquisa e extensão, onde os discentes em formação podem relacionar e aplicar a teoria e prática.

\section{REFERÊNCIAS}


ARAÚJO, Lidivânia de Freitas. Reflexões, desafios e possibilidades da Brinquedoteca em diferentes contextos: a garantia do direito de brincar Guarabira: UEPB, 2011.

BARDIN, L. Análise de Conteúdo. 3 ed. Lisboa, Portugal: Edições 70, 2004. $222 \mathrm{p}$.

BRASIL. Conselho Nacional de Educação. Define as Diretrizes Curriculares Nacionais para a formação inicial em nível superior (cursos de licenciatura, cursos de formação pedagógica para graduados e cursos de segunda licenciatura) e para a formação continuada. Resolução CNE/CP n. 02/2015, de $1^{\circ}$ de julho de 2015. Brasília, Diário Oficial [da] República Federativa do Brasil, seção 1, n. 124, p. 8-12, 02 de julho de 2015.

BRASIL. Estatuto da Criança e do Adolescente. Lei no 8.069 de 13 de julho de 1990. Dispõe sobre o Estatuto da Criança e do Adolescente e dá outras providências. Brasília, DF, 1990

BRASIL. Ministério da Educação e do Desporto. Referencial Curricular Nacional para a Educação Infantil. Secretaria de Educação Fundamental. Brasília: MEC/SEF, 1998. 3v

Brasil.BaseNacionalComumCurricular.EducaçãoéaBase.

http://basenacionalcomum.mec.gov.br/abase/

Brinquedos e companhia. São Paulo: Cortez, 2004.

BROUGÈRE G. Brinquedo e cultura. São Paulo: Cortez Editora, 2008. Coleção: Questões da nossa época; V.43.

BORGES, Angelita Salomão Muzeti. A EDUCAÇÃO INCLUSIVA E A FORMAÇÃO DOS PROFESSORES DO ATENDIMENTO EDUCACIONAL ESPECIALIZADO: análise na

rede municipal no interior de Minas Gerais. Faculdade de Ciências Humanas e Sociais Campus de Franca - SP.2017

CARNEIRO, Maria Angela Barbato. Brinquedoteca: um espaço interessante para favorecer o desenvolvimento da criança. São Paulo: PUC, 2015.

CARNEIRO,MariaÂngelaBarbato.Brinquedosebrincadeiras:formando ludoeducadores. São Paulo: Articulação/Universidade Escola, 2003.

CUNHA, Nylse Helena Silva. A brinquedoteca Brasileira. In: SANTOS, S. M. P. dos. (Coord.) Brinquedoteca: o lúdico em diferentes contextos. 7. ed. Petrópolis: Vozes, 1997. 
DINIZ, Luciene Teixeira. Material teórico Formação em Brinquedoteca. Cruzeiro do sul virtual. 2018.

FERREIRA, I. C. F; COELHO, M. T. de Q. Formação Pessoal: lúdico espaço para pensar e aprender. In: SANTOS, S. M. P. dos. (Coord.) A ludicidade como ciência. Petrópolis: Vozes, 2001.

FRIEDMANN,Adriana.OUniversosimbólicodacriança.2014.

http://territoriodobrincar.com.br/wp-

content/uploads/2015/06/Adriana_Friedmann_O_Universo_Simbolico_da_Cri anca.pdf

KISHIMOTO, Tizuko Morchida. BRINQUEDOS E BRINCADEIRAS NA EDUCAÇÃO INFANTIL1-FE-USP

http://portal.mec.gov.br/docman/dezembro-2010-pdf/7155-2-3-brinquedos-

brincadeiras- tizuko-morchida/file

KISHIMOTO, Tizuko Morchida. O jogo e a educação infantil. Perspectiva, n. 22, Florianópolis, UFSC/CED, NUP, 1994, , p. 105-128.

KISHIMOTO, Tizuko M. (Org.) O brincar e suas Teorias. São Paulo: Pioneira, 2002.

KRAMER, S. e LEITE, M. I. (Org.) Infância e produção cultural. 8ª edição. Campinas: Papirus, 1998.

MANZINI, E. J. Entrevista semi-estruturada: análise de objetivos e roteiros. In: Seminário Internacional sobre pesquisa e estudos qualitativos. Bauru: 2004. Disponível em: Acesso em: 5 abr. 2017.

MANZINI, Eduardo José e SANTOS, Maria Carmem Fidalgo. Recursos Pedagógicos Adaptados. Brasília / DF, 2002.

MINAYO, M. C. de S. Pesquisa Social. Teoria, método e criatividade. 18 ed. Petrópolis: Vozes, 2001.

MINISTÉRIO DA SAÚDE. Conselho Nacional de Saúde. Resolução № 466, de dezembro de 2012.

MOYLES, Janet R. Só brincar? O papel do brincar na educação infantil. Porto Alegre: Artmed, 2002.

Normas $\quad$ ABNT 2018. Disponível em< https://www.normaseregras.com/normas-abnt/> acesso 16 outubro de 2018.

MUNIZ, Maria C. Soto. A Brinquedoteca no contexto escolar da educação infantil. In: SANTOS, Santa Marli Pires dos. Brinquedoteca: a criança, o adulto e o lúdico. Petrópolis: Vozes, 2000. 
Santos, Ananda Pereira dos. A formação do pedagogo e a ludicidade: A prática do professor frente ao desenvolvimento infantil, por intermédio do brincar / Ananda Pereira dosSantos,2015.

https://repositorio.unesp.br/bitstream/handle/11449/126672/000837922.pdf?se quence $=1$ \&isAllowed=y

SANTOS, Santa Marli Pires dos. (Coord.) Brinquedoteca: o lúdico em diferentes contextos. Petrópolis: Vozes, 1997.

SOUZA, Luciana Carolina Cleto de. Brinquedotecas Comunitárias: O Lúdico como Ferramenta para Inclusão Social. Paraná: PUC, 2012.

ROEDER, Silvana Ziger. Brinquedoteca universitária: reflexões sobre o processo do brincar para aprender. 2008. Disponível < https://educere.bruc.com.br/arquivo/pdf2008/959_963.pdf> acesso 05 de julho de 2019.

VÁSQUEZ, A. S. Filosofia da práxis. Rio de Janeiro: Paz e Terra , 1968.

VEIGA, I. P. A. Inovações e projeto político-pedagógico: uma relação regulatória ou emancipatória? Cadernos Cedes, Campinas, v. 23, n. 61, p. 267281, dez. 2003.

VOLPATO, Gildo. Jogo, brincadeira e brinquedo: usos e significados no contexto escolar e familiar. Florianópolis: Cidade Futura, 2002. VYGOTSKY, Lev Semenovich. A formação social da mente. 6. ed. São Paulo: Martins Fontes,1998.

VYGOTSKY, Lev Semyonovich. A formação social da mente. São Paulo: Martins Fontes, 1989. 


\title{
CANTIGAS: uma ponte para o saber
}

\author{
SPIRLANDELI, Ana Beatriz Sousa \\ Graduanda em Matemática - Uni-FACEF \\ biaspirlandeli1998@hotmail.com \\ PEREIRA, Lais Lima \\ Graduando em Letras - Uni-FACEF \\ pereiralimalais8@gmail.com \\ VIEL, Silvia Regina \\ Docente - Uni-FACEF
}

\section{INTRODUÇÃO}

Para Caiado (2019), a música é reconhecida por muitos pesquisadores como uma espécie de modalidade que desenvolve a mente humana, promove o equilíbrio, proporcionando um estado agradável de bemestar, facilitando a concentração e o desenvolvimento do raciocínio, em especial em questões reflexivas voltadas para o pensamento filosófico. Segundo estudos realizados por pesquisadores alemães, pessoas que analisam tons musicais apresentam área do cérebro $25 \%$ maior em comparação aos indivíduos que não desenvolvem trabalho com música, bem como aos que estudaram as notas musicais e as divisões rítmicas, obtiveram notas $100 \%$ maiores que os demais colegas em relação a um determinado conteúdo de matemática.

É por este motivo, que consideramos extremamente importante o uso das cantigas como prática docente, não só como meio interdisciplinar de aplicar e praticar conteúdos a partir da música, mas também como meio de levar ao ambiente escolar informações sobre a cultura folclórica do Brasil.

De acordo com Santos (1998), as cantigas representam uma cultura passada de geração em geração que expressam grandes marcas da identidade brasileira. Foram usadas inicialmente pelos adultos como canção de ninar para as crianças, mas com o passar do tempo, se tornou um elemento forte da cultura folclórica brasileira.

A importância da presença dessa cultura no ambiente escolar é indiscutível. É preciso levar à escola um ambiente mais humanizado, que aproxime a vivência escolar dos estudantes à realidade social e cultural deles. Construir uma prática docente que utilize materiais culturais para aplicação de conteúdo, influencia diretamente na formação e capacidade crítica deste estudante. 
Tendo em vista essas reflexões, a proposta do artigo se baseia em discutir e propor uma aplicação interdisciplinar entre as disciplinas de português e matemática utilizando como instrumento pedagógico a cantiga Escravo de Jó. Será apresentado, após uma contextualização dos eixos abordados, conteúdos de possível aplicação presentes na cantiga, a partir do método interdisciplinar que se baseia em romper os paradigmas da estrutura educacional e levar aos jovens e criança, um ensino livre de fragmentações que aproxime a teoria à prática.

\section{CANTIGAS}

Segundo Cascudo (2002), os cancioneiros infantis são constituídos pelas cantigas entoadas por crianças em atividades lúdicas que fazem parte do contexto infantil. As cantigas são passadas de geração em geração, primeiramente entoadas por adultos com a finalidade de entreter, divertir e adormecer crianças. Existem diversas categorias de cantigas, canções de ninar, acalentar, cantigas de jogos, de rodas, entre outros.

As cantigas são categorizadas em grupos de canções identificadas por características específicas de seu uso: cantigas de jogos (com competição), Escravos de Jó; cantigas de passeio (brincadeiras, caminhadas com avanços e recuos), Havia um pastorzinho; cantigas de roda, Nesta rua. Nesta rua e Samba lelê; cantigas de história (nas quais a música identifica a personagem); cantigas cumulativas (a cada repetição entra um novo elemento no texto), A machadinha; cantigas de não findar (aqueles em que o final emenda com o começo), geralmente cantigas de roda e cantigas de ninar.

De acordo com Santos (1998), as cantigas são grandes expressões da cultura folclórica brasileira. Acredita-se que elas tenham origem de uma adaptação da música popular brasileira ou simplesmente surgiram anonimamente da oralidade do povo brasileiro. São músicas com uma melodia considerada simples, tonais, geralmente oitavadas e sem modulações de tons. O compasso é geralmente binário e raramente quaternário. Devido a evolução da tecnologia, globalização, e aumento das multimídias no cotidiano das crianças, as cantigas se tornaram menos frequentes no dia a dia das crianças em questão. Essa prática é mais presente nas escolas de educação infantil, que usam as cantigas como instrumento de aprendizagem e entretenimento infantil.

Ainda segundo Santos (1998), a estruturação da cantiga geralmente segue o mesmo padrão, as letras são de fácil memorização, cheia de rimas e trocadilhos, que fazem da cantiga uma brincadeira divertida com as quais as crianças brincam e aprendem ao mesmo tempo. As cantigas têm 
temáticas diferentes, mais voltadas para aspectos folclóricos, falando da vida dos animais típicos brasileiros criando uma situação fictícia a eles, relacionando-os ao cotidiano da vida humana, sendo a personificação um aspecto frequente nas cantigas brasileiras. Temos como exemplos as cantigas "Peixe Vivo", "A barata diz que tem" e "Sapo cururu". Esse aspecto de personificação de animais na cantiga, cria interesse e desperta sua atenção para a história que é contada, desenvolvendo assim sua memorização, imaginação e criatividade, além de aprender sobre o Folclore e diversas culturas brasileiras.

Para Santos (1998), as letras das cantigas podem sofrer variações regionais. De acordo com o contexto em que elas estão inseridas, podem ser cantadas de maneiras diversas, palavras são trocadas, acrescentadas ou retiradas na letra. Essas variações são comuns já que as cantigas são transmitidas oralmente de um povo para o outro. As cantigas são essenciais para reviver a cultura brasileira. Elas carregam um fardo muito importante para o Folclore do país, enriquecendo a identidade e a cultura, fazendo-se importante a tradição das cantigas na vida das crianças.

\subsection{Folclore}

Para falarmos de cantigas, é importante falar do cenário da cultura do folclore brasileiro, onde se consolida as cantigas como parte importante da identidade do país.

De acordo com Cascudo (2002), a palavra folclore é originária do inglês "Folklore" que significa "sabedoria popular". O significado de seu nome já nos diz tudo. Folclore é um conjunto de saberes, tradições, hábitos e costumes formados por danças, lendas, costumes e ditados que são passados de gerações em gerações.

O folclore representa uma cultura popular e tem total influência na identidade de uma nação. É de grande importância que as expressões culturais sejam propagadas através das gerações para que a tradição folclórica não desapareça e não perca sua essência.

No Brasil, o folclore é abundante e rico em várias manifestações, e o dia 22 de agosto, é destinado como uma data para a comemoração nacional. Segue abaixo, alguns exemplos de manifestações folclóricas no Brasil:

1. Lendas e histórias: Saci- Pererê, Mula sem cabeça, bichopapão, entre outros.

2. Estilo musical e dança: quadrilha, samba, entre outros.

3. Festas: festa junina, carnaval, entre outros. 
4. Cantigas de roda: Escravos de Jó, Ciranda cirandinha, entre outras.

Para Cascudo (2002), o Folclore é como o repertório de histórias populares (mitos e lendas) de uma determinada sociedade, que são repassadas oralmente de uma geração a outra ao longo da cultura de um povo. Assim como todas as outras tradições folclóricas do Brasil, as cantigas também tem extrema importância na construção da identidade cultural brasileira.

\title{
3. INTERDISCIPLINARIDADE
}

Com base nos Parâmetros Nacionais Curriculares, que dizem que o aprender se assemelha a uma teia e para que de fato haja aprendizado é necessário romper essa linearidade do ensino atual, que damos andamento ao artigo. Visando também a união das disciplinas de Letras e Matemática, buscamos atingir nosso fim último, o aprendizado dos alunos.

\begin{abstract}
Para que a aprendizagem possa ser significativa é preciso que os conteúdos sejam analisados e abordados de modo a formarem uma rede de significados. Se a premissa de que compreender é apreender o significado, e de que para apreender o significado de um objeto ou de um acontecimento é preciso vê-lo em suas relações com outros objetos ou acontecimentos, é possível dizer que a ideia de conhecer assemelha-se a de tecer uma teia. Tal fato evidencia os limites dos modelos lineares de organização curricular que se baseiam na concepção de conhecimento como "acúmulo" e indica a necessidade de romper essa linearidade (BRASIL, 1998, p. 75).
\end{abstract}

Para Fazenda (2011), é necessária essa interdisciplinaridade "para que o aluno se sinta parte de um todo e entenda a importância das suas atitudes para si e para o mundo." Vê-se, portanto, que é de suma importância que haja interdisciplinaridade na escola para que o aluno passe de uma posição passiva para ativa, visto que ele adquire consciência de que tudo está correlacionado.

Lembrando sempre que a individualidade de cada matéria não se perde por relacionar com outra, pois "a real interdisciplinaridade é antes uma questão de atitude supõe uma postura única diante dos fatos a serem analisados, mas não significa que pretenda impor-se, desprezando suas particularidades" (FAZENDA, 2011, p.59).

Muitos autores, de trabalhos sobre interdisciplinaridade, apontam a importância do tema para a formação de alunos críticos e com uma visão mais ampla, pois estimular o pensamento crítico é o mesmo que o tornar questionador e aluno que se questiona de todos os assuntos, aprende sempre mais. 


\section{ESCRAVOS DE JÓ: Explorando sua história e brincadeiras}

Cantiga: Escravos de Jó

Escravos de Jó, jogavam caxangá

Tira, põe, deixa ficar

Guerreiros com guerreiros fazem zigue zigue zá

Afinal de contas, quem foi Jó? Por que ele possuía escravos? O que é caxangá? Começaremos por etapas a desvendar a história da cantiga Escravos de Jó.

Não há nenhum relato em que Jó possuiu escravos, ele foi apenas um personagem bíblico do antigo testamento que possuía muitos bois, camelos, ovelhas e também inúmeros servos. Tudo isso, na época, era símbolo de riqueza. Por este motivo, Jó protagoniza a cantiga, como sendo dono de escravos, afinal, na escravidão, os senhores de engenho, eram pessoas de muita posse.

A cantiga diz que esses escravos jogavam caxangá. Existem três definições para caxangá. Uma delas, diz que significa um gorro de marinheiro. Outra que caxangá é uma espécie de Siri, azulado, encontrado nas Américas e Europa e que tem sua carne muito apreciada. A terceira definição para caxangá, segundo Francisco da Silveira Bueno no dicionário Tupi-GuaraniPortuguês, diz que é uma mata muito extensa. Portanto, não se sabe ao certo qual dos três conceitos é citado na cantiga, já que nenhum deles faz referência a um jogo.

$\mathrm{Na}$ época da escravidão, os capitães do mato (os escravos que eram libertados passavam a ser chamados de capitães do mato), ficavam de vigia, como guardas para apreenderem os escravos fugitivos. Na música, a expressão "guerreiros com guerreiros fazem zigue zigue zá" se refere aos escravos que faziam zigue zague, acredita-se que em meio a mata alta, para fugir desses capitães.

A cantiga Escravos de Jó, que é indicada para crianças a partir de 3 anos de idade, pode ser realizada em qualquer local amplo seja ser aberto ou fechado. A brincadeira estimula atenção, concentração, coordenação motora, linguagem, ritmo, memória e a cooperação entre crianças. O número ideal de participantes é acima de 4. É importante ressaltar que o professor tenha paciência com os participantes até que eles aprendam a dinâmica da brincadeira, pois cada pessoa possui o seu próprio ritmo que deve ser compreendido e respeitado.

Primeiramente, os participantes se sentam em um círculo e cada um deve ter em suas mãos um objeto pequeno, que será passado de mão em mão, de acordo com o ritmo juntamente com sua coreografia de "vai e vem" da cantiga Escravos de Jó. 

seguinte maneira:

De acordo com Medina (2005), a brincadeira acontece da

Escravos de Jó jogavam caxangá: nesse momento os participantes vão passando o objeto de um para o outro do lado direito, de maneira que cada jogador fique somente com um objeto, sempre.

Tira: cada indivíduo levanta o objeto que está em suas mãos.

Põe: colocam o objeto novamente no lugar.

Deixa ficar: apontam com o dedo para o objeto, indicando que fique quieto.

Guerreiros com guerreiros: voltam a passar o objeto para a direita.

Fazem Zigue: colocam o objeto na frente do jogador à direita, mas não soltam.

Zigue: colocam o objeto a frente do jogador a esquerda, mas não soltam.

Zá: colocam a objeto à frente do jogador à direita novamente.

Existem diversas adaptações com relação ao cantar e ao brincar Escravos de Jó, desde a confecção do objeto até a forma da disposição dos participantes de acordo com a idades ou a série na qual está aplicando.

As versões dessa cantiga possuem pequenas variações, dependendo da região em que é cantada. Logo temos estas versões:

Escravos de Jó ( Zé Pereira)

Escravos de Jó, jogavam caxangá

Escravos de Jó, jogavam caxangá.

Tira, bota, deixa o Zé Pereira ficar...

Guerreiros com guerreiros fazem zigue zigue zá

Guerreiros com guerreiros fazem zigue zigue zá.

Escravos de Jó ( Zambelê)

Escravos de Jó, jogavam caxangá

Escravos de Jó, jogavam caxangá.

Tira, bota, deixa o Zambelê ficar... 
Guerreiros com guerreiros fazem zigue zigue zá

Guerreiros com guerreiros fazem zigue zigue zá.

Escravos de Jó ( Cão Guerreiro)

Escravos de Jó, jogavam caxangá

Escravos de Jó, jogavam caxangá.

Tira, bota, deixa o Cão Guerreiro entrar...

Guerreiros com guerreiros fazem zigue zigue zá

Guerreiros com guerreiros fazem zigue zigue zá.

Escravos de Jó ( vamos a Belém)

Escravos de Jó, jogavam caxangá.

Tira, bota, vamos a Belém, que vai e vem

Guerreiros com guerreiros fazem zigue zigue zá

Guerreiros com guerreiros fazem zigue zigue zá.

Agora, em relação aos objetos que inicialmente eram utilizados na brincadeira, tinha-se desde uma pedra que cabia na mão da criança, assim como algumas variações: caixa de fósforo, latinhas, bambolê, bamboo, copo, balão ou objetos confeccionados pelos próprios alunos. Segue algumas imagens abaixo desta brincadeira:

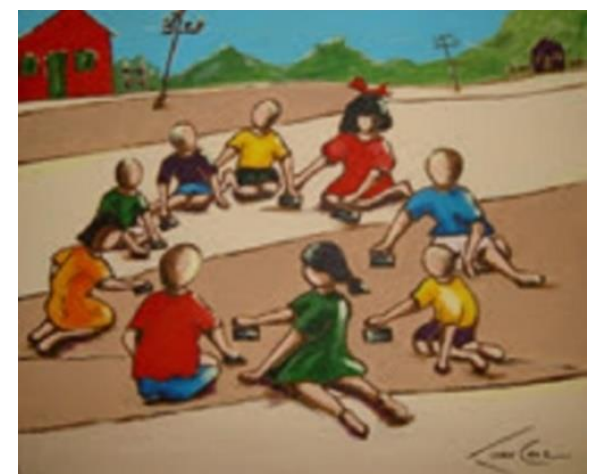

Fonte: Escravos de Jó. Muzeez. 04 de maio de 2017. Disponível em <https://muzeez.com.br/historias/escravos-de-jo/LPtHvCZKK45eJkZTz> Acesso $24 \mathrm{de}$ junho 2019. 


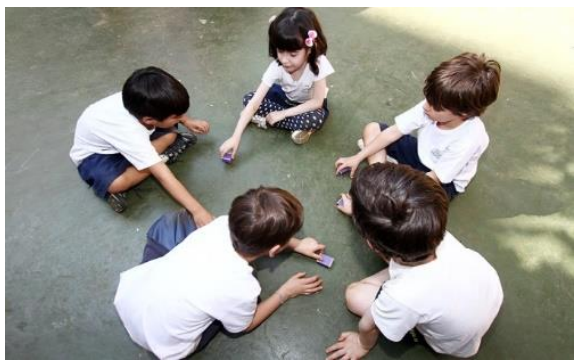

Fonte: Brincadeira de criança: Escravos de Jó. UOL. 11/10/2011. 07h00. Disponível em $<$ https://criancas.uol.com.br/novidades/2011/10/11/brincadeira-de-crianca-escravos-de-jo.htm> Acesso 24 de junho 2019.

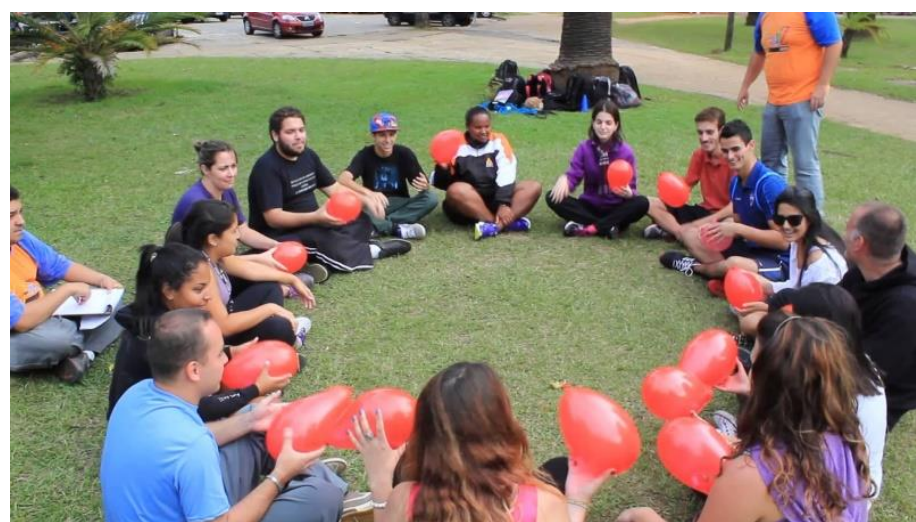

Fonte: Escravos de Jó. MultArt. 100 Brincadeiras de Crianças Divertidas da Infância. Disponível em <https://www.multarte.com.br/brincadeiras-de-criancas-divertidas/escravos-de-jo/> Acesso 24 de junho 2019.

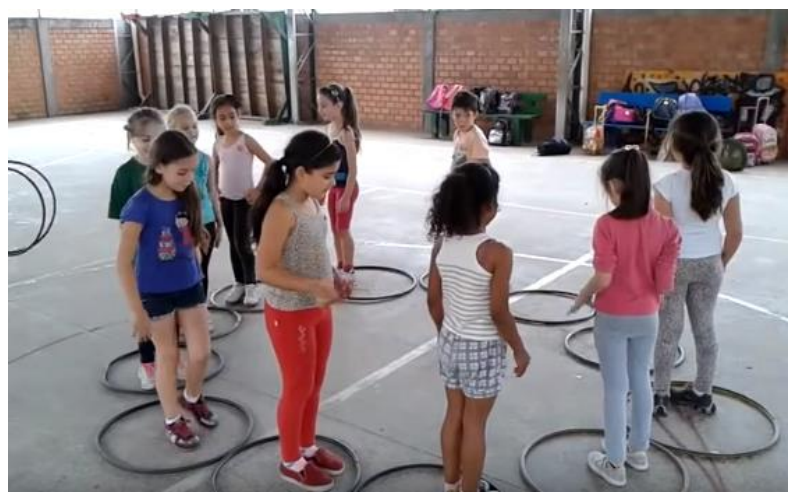

Fonte: Professora: Juliana Garcia. Atividades e Vivências. Ciências da Educação. 05/06/2018. Disponível em <https://cienciasdaeducacao.com.br/conteudo/escravos-de-jo-com-bambole/> Acesso 24 de junho 2019. 


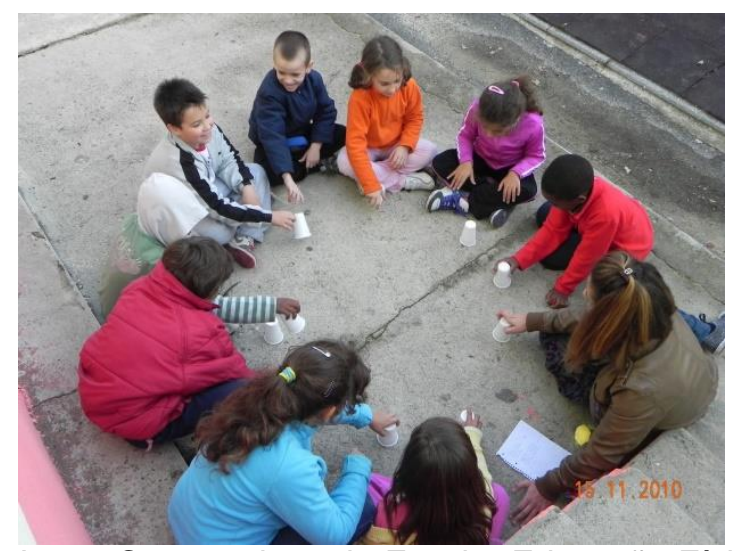

Fonte: Escravos de Jó. Jogos Cooperativos da Escola. Educação Física.29 de maio de 2015. Disponível em <https://cooperamosnaescola.wordpress.com/2015/05/29/escravos-dejo/> Acesso 24 de junho 2019.

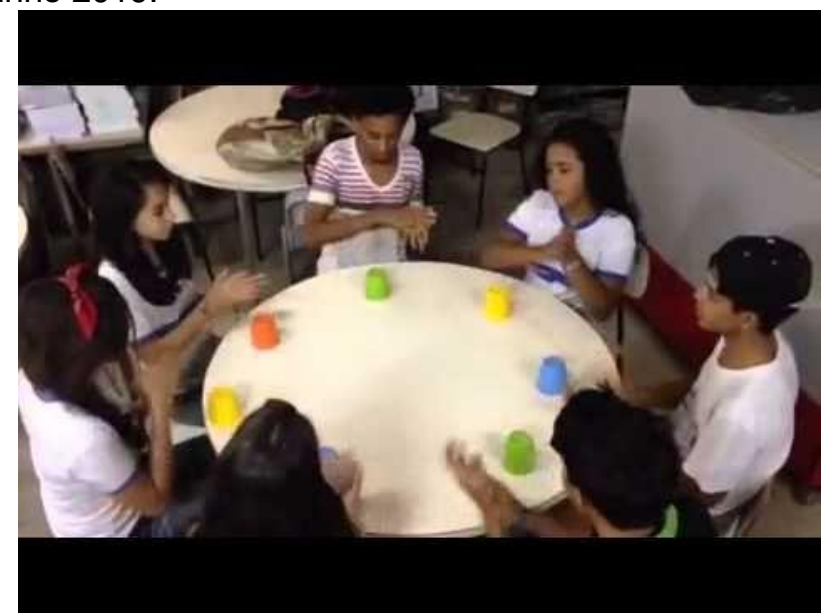

Fonte: Brincadeira de roda: Escravos de Jó. Disponível em <https://br.pinterest.com/pin/483855553694242338/> Acesso 24 de junho 2019.

Desta forma, fica a critério do professor os objetos que devem ser utilizados para se trabalhar a cantiga Escravos de Jó, já que estes devem estar relacionados aos objetivos que o professor quer alcançar com a atividade e os alunos.

\section{CONCEITOS DE PORTUGUÊS E MATEMÁtICA PRESENTES NA CANTIGA}

Além da diversidade de brincadeiras, já citadas anteriormente, a cantiga Escravos de Jó possui também alguns conceitos linguísticos e matemáticos envolvidos, se fazendo então, um objeto de interdisciplinaridade.

O esquema a seguir ilustra a relação dos movimentos com os números inteiros:

$+1+1$

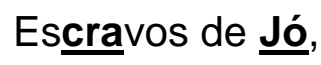
$+1+1$

jogavam caxangá 


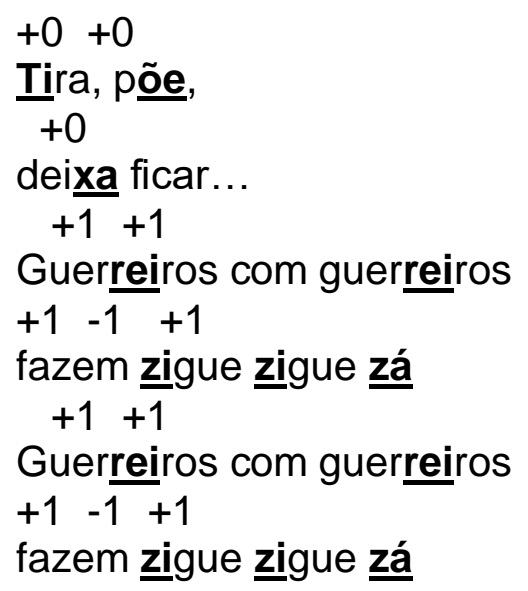

Onde os "+1" são as vezes que o objeto é passado para o lado direito. Os "+0" são quando o objeto fica em suas mãos, não é passado para a pessoa da direita nem da esquerda. Os "-1" são as vezes que objeto deve ser passado para a pessoa da esquerda, fazendo assim, o sentido oposto da brincadeira, sendo indicado, então, pelo sinal negativo. Se fizermos as contas dos movimentos feitos na brincadeira, e marcados no esquema acima, teremos 10, que significa a quantidade de passos ou em quantas mãos o objeto percorreu enquanto a música foi cantada apenas uma vez.

Em todas as versões mencionadas, a Matemática se faz presente na cantiga, de forma geral, quando relacionada a uma expressão algébrica, de acordo com a explicação abaixo:

Seja $p=10 m$ uma expressão em que $m$ será a quantidade de vezes que música será cantada e $p$ a quantidade de pessoas participantes da brincadeira.

Exemplo: Quantas vezes terei que cantar a música para que o objeto volte a sua posição inicial sabendo que tenho 20 pessoas?

$$
p=10 m \rightarrow 15=10 m \rightarrow m=\frac{15}{10} \rightarrow m=1,5
$$

Portanto, neste caso, quando a música for cantada por 2 vezes completa, o objeto estará em sua posição de origem.

Analisando a cantiga Escravos de Jó acerca dos conceitos linguísticos, podemos observar que a cantiga é escrita em versos livres, ou seja, não possui nenhuma métrica. Existem rimas na cantiga, todas terminadas com a vogal "a", ou seja, o esquema de rimas da cantiga é construído no formato de AAAA: caxanGÁ, fiCAR e ZÁ.

A cantiga possui sílabas tônicas alternadas em seus versos, que contribuem diretamente para a melodia e a entonação em que ela é cantada e 
também jogada. Pode-se perceber que, de acordo com a brincadeira, o objeto (copo por exemplo), é passado para o lado sempre nas sílabas tônicas do verso. Isso contribui diretamente no entendimento da canção para a criança. $O$ jeito em que ela é jogada e entoada, pode modificar os sentidos. Segue abaixo exemplo desse conceito das sílabas tônicas a partir de uma das diversas letras de Escravos de Jó:

\section{Escravos de Jó, jogavam caxangá}

Tira, põe, deixa o Zambelê ficar

Guerreiros com guerreiros fazem zigue zigue zá

Guerreiros com guerreiros fazem zigue zigue zá

As sílabas tônicas marcadas são a marcação da entonação da canção e do momento em que o objeto deve ser passado para o lado.

O ritmo da cantiga, contribui diretamente também para a memorização da letra para a criança. E não só isso, ao aplicar conceitos da língua portuguesa a partir de cantigas que façam parte do cotidiano da criança, é uma prática pedagógica muito mais produtiva e com mais resultados positivos, pois, a criança está aprendendo a partir de brincadeiras e canções que fizeram parte da construção de sua infância.

A partir de Escravos de Jó, é possível ensinar dentro da língua portuguesa, conceitos sobre a forma e estrutura do poema, combinação de rimas, conceitos sobre divisão silábica, tônicas, ritmos dos versos e principalmente, ensinar sobre a cultura folclórica brasileira.

\section{RELATO DA EXPERIÊNCIA NO PROGRAMA DE RESIDÊNCIA PEDAGÓGICA DO UNI-FACEF}

Iniciou-se no Programa de Residência Pedagógica vinculado ao UNI-Facef, um projeto de cantigas que era realizado semanalmente, e de onde se obteve uma experiência interdisciplinar entre os cursos de Licenciatura em Matemática e Letras. A princípio, se presenciou na prática a interação entre os residentes na construção do projeto com possíveis aplicações em turmas do ensino médio.

Desenvolveram-se no projeto, reflexões na área de Matemática, Português, sobre o folclore, a música e as brincadeiras. Os residentes, mesmo estando em faixas etárias superiores a 18 anos, desenvolveram a atividade da cantiga e se motivaram muito durante a brincadeira. Posteriormente se dividiram em grupos e cada um deles ficou responsável pela elaboração e pesquisa de uma dessas partes.

Foi definido então que a dinâmica se daria nos finais das reuniões, onde o grupo da brincadeira disponibilizava o objeto e o grupo da 
música cantava e tocava instrumentos, enquanto em conjunto todos, em uma grande roda, jogavam a cantiga.

A partir das brincadeiras realizadas nas reuniões do programa de Residência Pedagógica, foi reconhecido pelos residentes a importância de levar as cantigas como prática pedagógica dentro das escolas, desenvolvendo conceitos matemáticos e linguísticos presentes nas canções, levando arte e cultura para os estudantes de forma interdisciplinar e mostrando aos alunos que é possível aprender brincando.

\section{CONCLUSÃO}

É importante ressaltar que as instituições que oferecem cursos de licenciaturas têm um papel importante na formação de profissionais conscientes sobre o conceito de interdisciplinaridade e todas as suas consequências no ensino. Seguir carreira como docente exige aceitar desafios e saber lidar com as frequentes transformações sociais que atingem diretamente 0 ambiente escolar. Inovar, criar, aplicar novas formas pedagógicas que desenvolvam habilidades e a capacidade crítica dos estudantes enquanto seres pensantes, é muito significante para quem atua na área da educação.

Assim, a proposta da utilização das cantigas como uma ferramenta de interdisciplinaridade, vem corroborar a importância de transformações nas práticas pedagógicas presentes dentro das escolas, trabalhando Matemática e Português de forma interdisciplinar junto a arte e a cultura folclórica, proporcionando aos alunos uma prática docente diferenciada, a fim de promover um desenvolvimento relevante nos conteúdos disciplinares de forma lúdica e interativa.

\section{REFERÊNCIAS}

QUEM eram escravos de jó?. Fatos desconhecidos, 2019. Disponível em: $<$ https://www.fatosdesconhecidos.com.br/quem-eram-os-escravos-de-jo-e-porque-eles-jogavam-caxanga/>. Acesso em 09 de maio de 2019.

FOLCLORE. Significados, 2019. Disponível em:

<https://www.significados.com.br/folclore/>. Acesso em 16 de maio de 2019.

CASCUDO, Luís da Câmara. Dicionário do Folclore Brasileiro. 11. ed. ilustrada. São Paulo: Global, 2002. 
SANTOS, Gleusa. A origem das cantigas de roda. Revista Crescer, 1998.

Disponível em: <https://gleusasantos.wordpress.com/2008/10/17/a-origem-dascantigas-de-roda/>. Acesso em 16 de maio de 2019

O que é o caxanga?. Mundo estranho, 2019. Disponível em: $<$ https://super.abril.com.br/mundo-estranho/o-que-e-o-caxanga-que-osescravos-de-jo-jogavam/>. Acesso em 23 de maio de 2019.

MEDINA, Vilma. Escravos de Jó: Brincadeiras para crianças, 2015. Disponível em <https://br.guiainfantil.com/materias/cultura-e-lazer/cancoes-

infantis/escravos-de-jo-brincadeiras-para-criancas/>. Acesso em 09 de maio de 2019.

OLIVEIRA, Elisandra Brizolla de. SANTOS, Franklin Noel dos. 5 pressuposto e definições em interdisciplinaridade: diálogo com alguns autores, 2017. Disponível em:

<https://revistas.pucsp.br/interdisciplinaridade/article/download/34709/23806/> Acesso em 09 de maio de 2019.

CAIADO, Elen Campos. Brasil Escola, 2019. Disponível em: $<$ https://educador.brasilescola.uol.com.br/sugestoes-pais-professores/aimportancia-musica-no-processo-ensinoaprendizagem.htm.> Acesso em 06 de set. de 2019. 


\title{
DE TUDO, E COM TAL ZELO: um passeio pela poética de Vinícius de Moraes
}

\author{
BASTOS, Gene Emanuel Guedes \\ Graduando em Letras-Uni-FACEF \\ mano_bastos@hotmail.com \\ RODRIGUES, Lindsay Amanda \\ Graduanda em Letras-Uni-FACEF \\ lindsayamanda2@gmail.com \\ IVAN, Maria Eloísa de Souza \\ Doutora em Estudos Literários - Uni-FACEF \\ meloisaivan@gmail.com
}

\section{INTRODUÇÃO}

Este trabalho tem por objetivo apresentar uma das sequências didáticas elaboradas sobre o gênero lírico, destacando-se o poeta Vinícius de Moraes e dois de seus sonetos mais famosos: "Soneto do maior amor" (1938) e "Soneto da fidelidade" (1939), ambos pertencentes à obra Poemas, Sonetos e Baladas, de 1946.

Esta sequência didática foi desenvolvida com alunos dos sétimos, oitavos e nonos anos do Ensino Fundamental II das Escolas Estaduais Capitão José Pinheiro de Lacerda e E.E David Carneiro Ewbank da cidade de Franca$\mathrm{SP}$ vinculadas ao Programa de Iniciação à Docência PIBID/CAPES-Uni-FACEF 2018/2019, de forma interdisciplinar envolvendo os cursos de licenciaturas em Letras e Matemática com o objetivo principal de trabalhar competências e habilidades para leitura de textos literários, audiovisuais, bem como da linguagem matemática apresentada em situações-problema.

No ano de 2018, o projeto contemplou o gênero narrativo; já neste ano de 2019, privilegiou, no primeiro semestre, o gênero lírico, iniciando com o poeta Mario Quintana estabelecendo-se a interdisciplinaridade com a Matemática por meio da obra do muralista de reconhecimento nacional e internacional Carlos Eduardo Fernandes, mais conhecido como Kobra, que neste ano de 2019 produziu o mural em homenagem ao poeta gaúcho, na cidade de Porto Alegre/RS.

Finalizado o trabalho com Quintana, elegeu-se o poeta $\mathrm{e}$ compositor Vinícius de Moraes como objeto de estudo. Coordenadoras, supervisores e os alunos bolsistas do PIBID desenvolveram atividades e 
experiências no UNI-FACEF para serem aplicadas aos alunos das escolas parceiras.

A sequência didática aqui destacada tem como propósito ampliar os conhecimentos do gênero lírico tanto no que se refere à estrutura e sua materialização no objeto artístico, quanto aos sentidos que afloram do texto poético, pois de acordo com a Matriz de Avaliação Processual, que propõe o currículo básico para as escolas do Estado de São Paulo, algumas das habilidades e competências propostas são reconhecer os efeitos de sentido produzidos pelo uso da linguagem figurada em diferentes textos, incluindo os textos literários e letras de música, bem como identificar os recursos discursivos e semânticos expressos nesses textos.

Para tanto, inicialmente, fez-se a escuta e interpretação da música "Aquarela", de Toquinho, uma das mais importantes parcerias de Vinícius de Moraes, a fim de sensibilizar os alunos assistidos pelo programa, além de despertar-Ihes o interesse pela obra do poeta e compositor Vinícius de Moraes e, posteriormente, foram trabalhados os sonetos.

Dessa forma, adotou-se, como procedimento metodológico uma pesquisa de abordagem bibliográfica, destacando-se o gênero lírico e sua consequente aplicabilidade no Ensino Fundamental II. O embasamento teórico acerca de sequências didáticas está fundamentado nas reflexões propostas por Schneuwly e Dolz (2004). No que se refere à teoria do gênero lírico, foram utilizadas as considerações de Candido (2006), Goldstein (2004), Rosenfeld (2006) e Soares (2004). Para falar do autor e de sua produção artística foram utilizadas, sobretudo, as reflexões de Ferraz (2008); Faria (2008), entre outras fontes.

\section{VIDA E OBRA DE VINÍCIUS DE MORAES}

Conforme dito anteriormente, nosso trabalho interdisciplinar entre as licenciaturas de Letras e Matemática, realizado nas escolas parceiras, iniciou o trabalho com o poeta e compositor Vinícius de Moraes apresentando aos discentes assistidos pelo Programa a biografia do artista, destacando-se não apenas a sua participação no contexto político-social do país, como também a sua importância dentro do cenário das artes tanto literária, quanto da música, sendo o poeta, um dos idealizadores da Bossa Nova, movimento artístico da MPB, na década de 50.

$\mathrm{Na}$ obra História concisa da literatura brasileira, Alfredo Bosi (1975) destaca o fazer literário viniciano e nos chama a atenção para a habilidade de o poeta produzir obras capazes de traduzir as vicissitudes do amor na sua condição carnal, mas também o alargamento de sua temática, que 
revela uma poesia de engajamento político-social capaz de ver e denunciar as desigualdades sociais como em "O operário em construção" (1969).

Assim, iniciamos nosso trabalho com a intenção de sensibilizar e aproximar os alunos assistidos da produção artística do poeta. Para tanto, fizemos, em um primeiro momento, uma abordagem oral, perguntando quem já o conhecia, ou alguma de suas obras ainda que só de ouvir falar; em seguida, fez-se a escuta e interpretação da música "Aquarela", de Toquinho, uma das mais importantes parcerias de Vinícius de Moraes; posteriormente, foi apresentada a biografia do autor, contextualizando-o dentro do Movimento modernista brasileiro e da música brasileira. Desse modo, por meio de pesquisa, tanto no site oficial do autor, como em trabalhos de pesquisadores sobre o poeta foram apresentados, por meio de slides, autor e sua obra artística, conforme descrito nesta seção.

\subsection{Biografia}

Nascido e registrado com o nome de Marcus Vinícius da Cruz de Mello Moraes, Vinícius de Moraes nasceu em 19 de outubro de 1913, na cidade do Rio de Janeiro, mesmo lugar de sua morte em 1980. Herdeiro e afortunado de dotes musicais, o interesse do então menino começou desde cedo, quando aos onze anos já cantava em um coral do Colégio de Jesuítas em que estudava, e começo a montar também peças de teatro.

Em 1930, ingressou na Faculdade de Direito do Catete e três anos mais tarde, formou-se em Ciências Jurídicas e Sociais, galgando vários cargos, entre eles, censor cinematográfico, crítico de cinema e também a diplomacia, em que dedicou vinte e dois anos de sua carreira até ser afastado por seu comportamento boêmio que o impedia de cumprir suas funções.

Ainda na década de 1930, Vinícius de Moraes estabeleceu amizade com os poetas Manuel Bandeira, Mário de Andrade e Oswald de Andrade. Em sua fase considerada mística, ele recebeu o Prêmio Felipe D'Oliveira pelo livro Forma e exegese, de 1935. No ano seguinte, lançou o livro Ariana, a mulher.

Vinícius de Moraes foi um poeta significativo da Segunda Fase do Modernismo Brasileiro. Ao publicar sua Antologia Poética, em 1955, admitiu que sua obra poética se divide em duas fases: a primeira fase carregada de misticismo e profundamente cristã, começa em O caminho para a distância (1933) e, termina com o poema, "Ariana, a Mulher" (1936). A segunda fase, iniciada com Cinco elegias (1943), assinala a explosão de uma poesia mais viril. Nela, segundo o poeta, estão nitidamente marcados os movimentos de 
aproximação do mundo material, com a difícil, mas consistente repulsa ao idealismo dos primeiros anos.

Ao englobar o "mundo material" em sua produção artística, Vinícius de Moraes se inclina por uma lírica comprometida com o cotidiano, onde buscou os grandes dramas sociais do seu tempo. Os poemas "Rosa de Hiroshima" (1954) e "Operário em construção" (1956), são exemplos desse engajamento social.

Vinícius de Mores conheceu o prestígio com a peça teatral Orfeu da Conceição, de 1956. Além da diplomacia, do teatro e dos livros, sua carreira musical começou a deslanchar em meados da década de 1950 sendo o poeta um dos idealizadores da Bossa Nova, movimento artístico da MPB, que teve como parceiros fundamentais o maestro Tom Jobim (um de seus grandes parceiros) e o compositor e cantor João Gilberto.

Moraes teve diversas de suas composições gravadas por inúmeros artistas, sendo que na década seguinte, o artista viveu um período áureo na MPB, tendo sido gravadas cerca de sessenta composições de sua autoria. Foram firmadas parcerias com compositores como Baden Powell, Carlos Lyra e Francis Hime.

Na década de 1970, já consagrado e com um novo parceiro, o violonista Toquinho, Vinícius seguiu lançando álbuns e livros de grande sucesso.

Toquinho e Vinícius se conheceram oficialmente na Itália, apesar de o primeiro já ter o segundo como ídolo há muito tempo. Toquinho era amigo de Chico Buarque e tinha ido para a Europa fazer companhia durante o exílio de Chico. Ao conhecer Vinícius, com vinte e três anos, iniciaram uma parceria que só terminaria com a morte do poeta.

Nesses onze anos de parceria, foi Toquinho quem acompanhou Vinícius na sua fase mais popular de público e mais incompreendido pela crítica. Foi quando o poeta se libertou de uma série de convenções e caiu no mundo com uma série infindável de shows e discos. A dupla fez, entre gravações de estúdio e ao vivo, mais de quinze discos nesse período, além de clássicos como "Tarde em Itapuã", "Carta ao Tom" e "Regra três".

A parceria Vinícius/Toquinho excursionou por várias cidades brasileiras e também pelo exterior. Ainda em 1971, a dupla lançou seu primeiro LP de estúdio, com destaque para "Maria vai com as outras", "Morena Flor", "A rosa desfolhada" e "Testamento". Em 1972, eles lançaram o álbum "São demais os perigos dessa vida", contendo, além da faixa-título, grandes sucessos como "Cotidiano no 2", "Para viver um grande amor" e "Regra três". Com Toquinho, também compôs a trilha sonora da telenovela "Nossa filha Gabriela" (da extinta TV Tupi), registrada em disco naquele mesmo ano. 
Em 1975, Vinícius de Moraes lançou o álbum "O poeta e o violão". Gravado em Milão, o LP teve a participação especial dos maestros Bacalov e Bardotti. No mesmo ano, a gravadora Philips lançou o álbum "Vinícius e Toquinho". Deste LP, destaca-se "Onde anda você" - parceria com Hermano Silva e que alcançou grande sucesso. Ainda naquele ano, Vinícius lançou o livro de poemas infantis A Arca de Noé. Na madrugada de 9 de julho de 1980, Vinícius de Moraes começou a se sentir mal na banheira da casa onde morava, na Gávea, morrendo pouco depois. O poeta passou o dia anterior com o parceiro e amigo Toquinho, com quem planejava os últimos detalhes do volume 2 do álbum Arca de Noé. Foi sepultado no Cemitério de São João Batista, no Rio de Janeiro. Em 1981, este LP foi lançado.

Para este trabalho, foram separados dois sonetos do poeta, sendo eles "Soneto da fidelidade" e "Soneto do amor maior", ambos pertencentes à obra Poemas, Sonetos e Baladas, de 1946. Em 1994, José Castello lança com o título Vinícius de Moraes: o poeta da paixão - uma biografia, uma biografia sobre autor, onde exalta, dentre outras coisas, seu fazer literário. De acordo com Castello (1994), o poeta, foi antes de tudo, um apaixonado, que viveu para jogar com as ilusões e com a credulidade e como mesmo se dizia "eu sou um labirinto em busca de uma saída", o que revela sua inquietude.

Ainda segundo Castello (1994) o que torna Vinícius um grande poeta é a sua capacidade e percepção sobre o lado obscuro do homem, que deve ter audácia em se enfrentar. O "Soneto da fidelidade" (1939) traz as declarações e juras de um amante para sua amada, comprovando a escrita galante do autor. Com o "Soneto do amor maior" temos um eu-lírico mais possessivo, de amor exacerbado, onde verifica-se as diversas nuances e formas que a obra viniciana retrata o amor.

A transcrição dos dois sonetos, bem como as atividades desenvolvidas estão mais à frente apresentadas.

\section{O GÊNERO LÍRICO}

O artista literário trabalha com uma matéria-prima: a palavra. No entanto, a palavra em si não basta para se obter um bom texto; é necessário que ela seja trabalhada num processo de seleção e arrumação vocabular e exploração dos sentidos. Esse processo caracteriza a linguagem poética.

A linguagem poética explora o sentido plurissignificativo, conotativo das palavras, isto é, não o sentido frio e impessoal, "em estado dicionário", mas sim o sentido figurado, metafórico, passível de interpretações. 
Os gêneros, bem como a própria ideia de literatura são fenômenos dinâmicos em constante processo de mudança (Luiz Costa Lima).

O gênero lírico é considerado o mais subjetivo dos três gêneros, pois materializa estados de alma do eu-lírico, isto é, suas emoções, ideias e impressões em face ao mundo exterior. Assim, a voz que se manifesta no gênero lírico é a do eu-lírico, que não se confunde com a voz do autor. Normalmente, os pronomes e verbos estão em 1ํㅡ pessoa e há o predomínio da função emotiva da linguagem.

Não se pode considerar a linguagem poética como mero instrumento para expressar significados que não possam ser constatados, intrinsecamente, na maneira como se estrutura esse organismo que é a obra da arte.

3.10 funcionamento do discurso poético: a estrutura do poema e do soneto

As palavras são organizadas, em texto, por meio dos quais podem criar significados capazes de transmitir sentimentos, ideias, desejos, emoções, pensamentos. Esse trabalho de elaboração da palavra faz uso das chamadas figuras de linguagem ou de estilo.

Figura de linguagem é uma forma de expressão que consiste no emprego de palavras em sentido figurado, isto é, em um sentido diferente daquele em que convencionalmente são empregados. Essas figuras são recursos normalmente utilizados para tornar mais expressivo o que queremos dizer, ou para ampliar o significado de uma palavra, suprir a falta de um termo adequado, criar novos e diferentes sentidos.

Entre as figuras de linguagem mais frequentes estão: a metáfora, a metonímia, a antítese, o paradoxo, a ironia, a gradação, a prosopopeia ou personificação, a elipse, o polissíndeto, a paronomásia, anáfora, o hipérbato, a aliteração, a assonância e outras.

O poema, assim como o soneto, é uma composição textual que se constrói não apenas com ideias e sentimentos, mas também por meio de emprego do verso e seus recursos musicais - a sonoridade e o ritmo das palavras, que emanem do modo como as palavras são arranjadas, criando o discurso literário. O poema é o "lugar" da poesia. O soneto é uma forma de poema.

A palavra soneto, de origem italiana sonetto, do provençal sonet, de son, melodia, canção, significa pequeno som. É um tipo de poema de catorze versos, dispostos em dois quartetos e dois tercetos apresentados normalmente, o seguinte esquema de rimas: $A B A B / A B A B / C D C / C D C$; contudo, 
esse esquema tem variado bastante no decorrer dos tempos. Ao apresenta-se em dois quartetos e dois tercetos é denominado petrarquiano; quando estruturado em três quadras e um dístico chama-se inglês ou shakespeariano.

A palavra é a unidade do trabalho do poeta e a peça que acompanha o verso. Palavra como conceito, como ligação, como matiz do conceito, como unidade sonora que desperta um prazer sensorial pela sua própria articulação: durezas de guturais, explosões de labiais, suavidades de línguas. O ritmo cria a unidade sonora do verso; as palavras criam a unidade conceitual; a unidade sonora e a unidade conceitual formam a integridade do verso, que é a unidade do poema.

Verso é, então, uma sucessão de silabas ou fonemas formando uma unidade rítmica e melódica, que corresponde, normalmente, a uma linha do poema, ou soneto.

Os versos organizam-se em estrofes, também chamadas de estâncias que é um agrupamento de versos.

O número de versos agrupados em cada estrofe pode ser variado. Chama-se dístico a estrofe de dois versos, de terceto a estrofe de três versos, quarteto ou quadra a de quatro versos, e assim sucessivamente.

A melodia que caracteriza o verso é resultado de alguns recursos poéticos encontrados nas poesias de todos os tempos. Os mais importantes são: a métrica, o ritmo, a rima, a aliteração e a assonância.

A divisão de um verso em segmentos, não se refere as sílabas tomadas em relação umas às outras, mas aos segmentos rítmicos, que permitem variar a modulação e adaptá-las às necessidades expressivas. Ao número de sílabas poéticas de um verso chama-se métrica; ao número de segmentos rítmicos, chama-se ritmo. A métrica é, então, a medida dos versos.

Os elementos sonoros propriamente ditos estão, no poema, intimamente ligados, e mesmo subordinados ao fenômeno dominante do ritmo, que é justamente uma forma de combinar as sonoridades não dos fonemas, mas das combinações de fonemas que são as sílabas e os pés. Podemos chamar de ritmo a cadência regular definida por um compasso e, noutro extremo, a disposição das linhas de uma paisagem. O ritmo é inseparável da frase, não é composto só de palavras soltas nem é só medida e quantidade silábica, acentos e pausas; ele é também imagem e sentido.

O ritmo está ligado intimamente à ideia de alternância: alternância de som e silêncio; de graves e agudos; de tônicas e átonas; de longas e breves, em combinações variadas.

Assim, em poesia, o ritmo se dá pela alternância de sílabas acentuadas e não acentuadas, ou seja, sílabas que apresentam maior ou 
menor intensidade em sua enunciação. O conceito poético de sílaba acentuada nem sempre coincide com o conceito gramatical de sílaba tônica. A acentuação de uma sílaba é determinada pela sequência melódica a que ela pertence.

Dentre os recursos para obter certos efeitos especiais do verso, o principal é a rima que, segundo Manuel Bandeira, "é a igualdade ou semelhança de sons na terminação das palavras" (BANDEIRA apud CANDIDO, 2006, p.61).

A rima é, então, um recurso musical baseado na semelhança sonora das palavras no final dos versos e, às vezes, no interior dos versos (rima interna). As rimas classificam-se em interpoladas, alternadas e emparelhadas, segundo sua organização em esquemas $A B B A, A B A B A$ e AABB.

Na poesia moderna, a rima regular deixou de ter a importância que representava em séculos anteriores. Pode ou não ser empregada de acordo com as necessidades de expressão do poeta, pois o ritmo é a unidade da frase que produz imagem e sentido. A seguir, apresentamos as atividades da sequência didática desenvolvida com os alunos das escolas parceiras do PIBID/CAPES-Uni-FACEF 2018/2019.

\section{O PIBID NA SALA DE AULA: Explorando o gênero lírico}

De acordo com Dolz, Noverraz e Schneuwly (2004, p.53), entende-se, por sequência didática, um conjunto de atividades escolares organizadas, de maneira sistemática, em torno de um gênero textual oral ou escrito a qual procura favorecer a mudança e a promoção dos alunos ao domínio dos gêneros e das situações de comunicação. Pode-se dizer, ainda, que sequências didáticas são "etapas continuadas" ou "conjuntos de atividades" de um tema que tem por objetivo ensinar um conteúdo, etapa por etapa.

Portanto, em uma SD, na organização do trabalho com um gênero textual, o professor deve abordar os elementos necessários para definição das características textuais do gênero em estudo, identificando os instrumentos linguísticos que permitem compreender a estrutura e a composição textual e explorar os três elementos que caracterizam o gênero: conteúdo, estilo e composição. A vantagem desse tipo de trabalho é que leitura, escrita, oralidade e aspectos gramaticais são trabalhados em conjunto, o que faz mais sentido para quem aprende.

Nessa seção, subsidiados pelo entendimento da relevância de se trabalhar com sequências didáticas, são apresentadas as atividades propostas em Português, destacando-se a leitura e interpretação textual, além da 
estrutura do soneto, bem como a contextualização do poeta Vinícius de Moraes.

Assim, iniciamos nosso trabalho com a intenção de sensibilizar e aproximar os alunos assistidos da produção artística do poeta. Para tanto, fizemos, em um primeiro momento, uma abordagem oral, perguntando quem já o conhecia, ou alguma de suas obras ainda que só de ouvir falar; em seguida, fez-se a escuta e interpretação da música "Aquarela", de Toquinho, uma das mais importantes parcerias de Vinícius de Moraes; posteriormente, foi apresentada, por meio de slides, a biografia do poeta, contextualizando-o dentro do Movimento modernista brasileiro e da música brasileira.

Em seguida, a fim de alcançar o objetivo proposto, o aprofundamento e estudo sobre o gênero lírico, iniciamos as atividades pela leitura dramatizada e interpretativa de dois conhecidos sonetos vinicianos, "Soneto da fidelidade" e "Soneto do maior amor", respectivamente. Para a execução das atividades em Português, foram necessárias quatro aulas.

Inicialmente, transcrevemos abaixo os dois sonetos:

\section{SONETO DE FIDELIDADE}

De tudo, ao meu amor serei atento Antes, e com tal zelo, e sempre, e tanto Que mesmo em face do maior encanto Dele se encante mais meu pensamento.

Quero vivê-lo em cada vão momento E em louvor hei de espalhar meu canto E rir meu riso e derramar meu pranto Ao seu pesar ou seu contentamento.

E assim, quando mais tarde me procure Quem sabe a morte, angústia de quem vive

Quem sabe a solidão, fim de quem ama

Eu possa me dizer do amor (que tive): Que não seja imortal, posto que é chama Mas que seja infinito enquanto dure.

Estoril, outubro de 1939

\section{SONETO DO MAIOR AMOR}

Maior amor nem mais estranho existe

Que o meu, que não sossega a coisa amada

$E$ quando a sente alegre, fica triste

E se a vê descontente, dá risada. 


\author{
E que só fica em paz se lhe resiste \\ $O$ amado coração, e que se agrada \\ Mais da eterna aventura em que persiste \\ Que de uma vida mal-aventurada \\ Louco amor meu, que quando toca, fere \\ E quando fere vibra, mas prefere \\ Ferir a fenecer - e vive a esmo \\ Fiel à sua lei de cada instante \\ Desassombrado, doido, delirante \\ Numa paixão de tudo e de si mesmo.
}

Oxford, 1938

Para auxiliar os alunos quanto à compreensão da estrutura, bem como do conteúdo humano materializados pelo gênero lírico, foram elaboradas as seguintes atividades 20

Atividades desenvolvidas para o 'Soneto da fidelidade'

1) Observe o verbete de dicionário seguinte:

Antes adv. Num momento ou tempo anterior: cheguei antes de você! Antigamente: num tempo passado, antigo: ele não é como antes. Melhor: de maneira preferível - antes agora do que há uns anos. Primeiramente; que ocorre em primeiro lugar: antes o café, depois o almoço! Pelo contrário: não era verdadeiro, antes é muito mentiroso. Tendencialmente para: ele é antes burro do que inteligente. (https: //www.dicio.com.br/antes/)

\section{Agora responda:}

a) De acordo com o sentido apresentado no poema, qual a melhor definição, dentre as que estão acima apresentadas?

b) Escreva uma oração com a palavra ANTES, utilizando o mesmo sentido do poema.

2) A palavra $\mathrm{VÃO}$, usada no $5^{\circ}$ verso, classifica-se, morfologicamente, como:
a) Substantivo;
b) Verbo;
c) Adjetivo
d) Conjunção

Justifique sua resposta.

3) O "Soneto da fidelidade" é formado por:

a) Quantos versos?

b) Quantas estrofes?

20 Todas as atividades aqui apresentadas foram elaboradas pelos integrantes do projeto PIBID/CAPES-Uni-FACEF 2018-2019, ou seja, pelas coordenadoras de área, supervisores e pelos bolsistas de Iniciação à Docência. 
c) Possui esquema de rimas? Se sim, como se identifica esse esquema?

d) Quais são as duas possíveis formas de se estruturar um soneto? Como identificamos cada uma delas?

4) Faça a escansão (contagem das sílabas poéticas de um verso, que se realiza por meio dos sons das palavras) das sílabas poéticas dos seguintes versos:

"Quero vivê-lo em cada vão momento/E em seu louvor hei de espalhar meu canto"

5) Faça a correlação entre as figuras de linguagem e os versos selecionados

(a) Antítese: indicação de oposição;

(b) Paradoxo: associação de conceitos contraditórios

( ) E rir meu riso e derramar meu pranto

( ) Mas que seja infinito enquanto dure.

6) Qual o tema apresentado por este soneto?

7) Faça uma leitura interpretativa da última estrofe do "Soneto da fidelidade".

8) Escreva um parágrafo argumentativo sobre o tema "Fidelidade", orientando-se pela seguinte estrutura:

a) Apresentação do tema

b) Tese

c) Dois argumentos para embasar sua tese

d) Uma conclusão

Mínimo de 5 e máximo 8 linhas.

9) Agora os artistas são vocês... Em duplas, criem um soneto, que tenha como tema a fidelidade, podendo ser entre amigos, casais, pais e filhos, enfim, em qualquer tipo de relacionamento que vocês desejem materializar.

Com a proposta de produção de texto na questão 9, destacamos os sonetos de três alunos: 


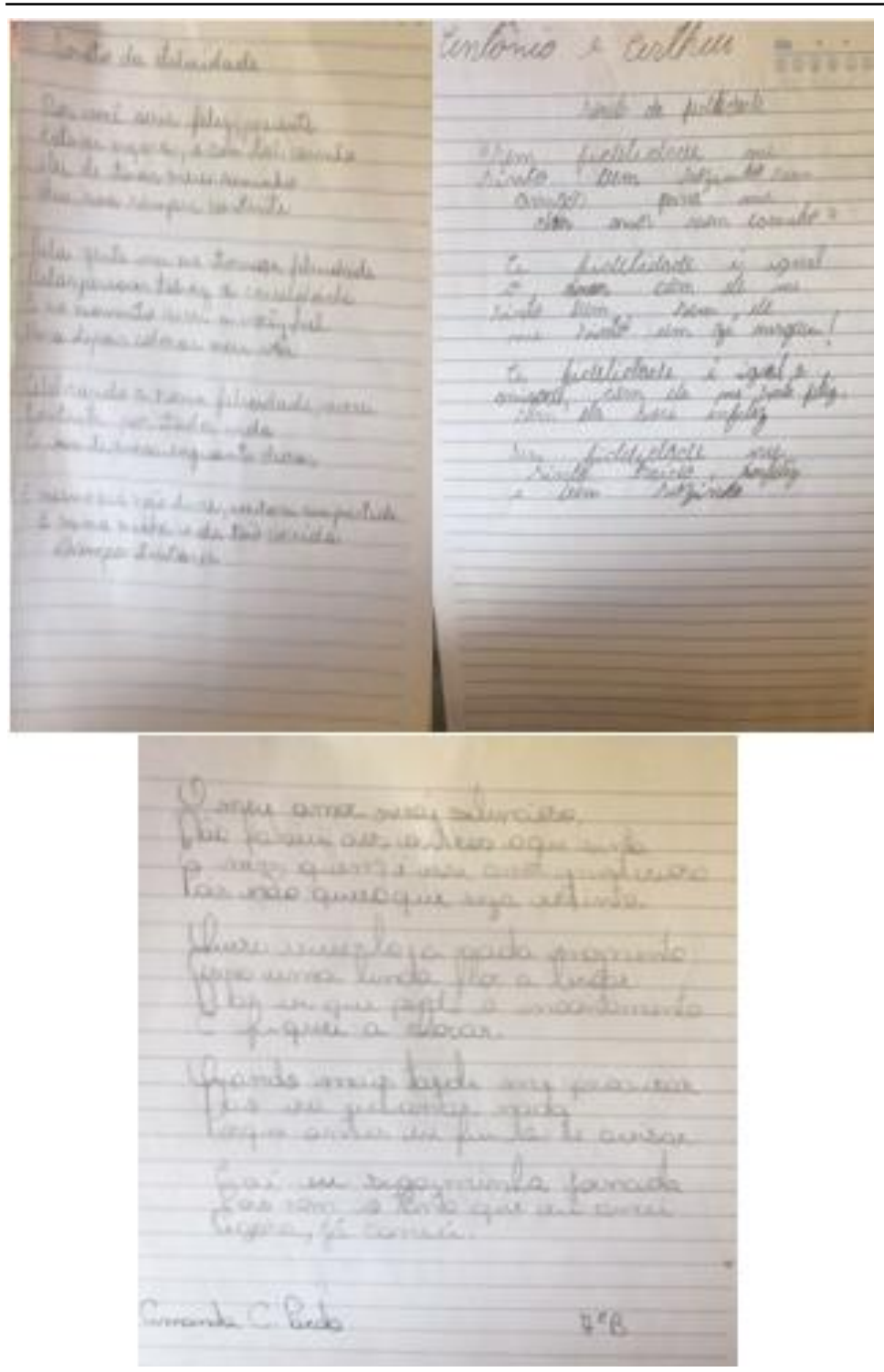

Atividades desenvolvidas para o 'Soneto do maior amor'

1) Pesquise no dicionário o significado das palavras fenecer e esmo. Copie as definições em seu caderno e, em seguida, destaque uma das definições que pode ser aplicada ao poema.

2) Leia a definição de Gradação:

A gradação, também conhecida por clímax (...) lida com aspectos interpretativos da fala ou do texto, alterando a percepção do leitor ou do interlocutor em questão. (...) A principal função desta figura de linguagem é propor uma sequência de palavras e/ou expressões que intensifiquem uma mesma ideia ou elemento a fim de destacar este componente dos demais, demonstrando uma espécie de crescimento ou evolução pelo qual ele passou no enunciado.

EXEMPLOS: "Aqui...além...mais longe por onde eu movo o passo." (Castro Alves) 
"Aquilo é estranho, feio... me dá nojo!"
(https://figurasdelinguagem.com.br/gradacao/)

Agora volte ao poema, releia-o e copie de lá um ou mais versos que materializem a gradação.

3) Regência verbal é a parte da língua que se ocupa da relação entre os verbos e os termos que se seguem a ele e completam o seu sentido. Alguns verbos possuem regência culta e popular diferentes. Um bom exemplo disso é o verbo PREFERIR, usado no poema estudado. Popularmente, usamos o preferir como verbo transitivo, porém com o uso de conjunções comparativas, bem como com intensificadores. Isso não é o que sugere a regência culta, a qual classifica o preferir como VTDI, usado obrigatoriamente com a preposição $A$ e sem qualquer intensificador. Ex.: Prefiro mais a cor roxa do que a amarela. (regência popular) Prefiro a cor roxa à amarela (regência culta).

a) Transcreva do poema o verso que mostra a regência culta do verbo preferir.

b) Escreva um período em que mostre a regência desse verbo, também de forma culta.

4) Leia, atentamente, os versos "mas prefere /ferir a fenecer/ e vive a esmo" $\left(10^{\circ}\right.$ e $\left.11^{\circ}\right)$; em seguida, comente o que você entende deles.

5) Releia o poema e, então, identifique o tema descrito nesse soneto.

6) Levando em consideração a primeira estrofe deste soneto, como podemos compreender o sentimento do eu-lírico em relação à mulher amada?

\section{CONSIDERAÇÕES FINAIS}

Conforme dito anteriormente, o objetivo deste artigo foi o de apresentar as atividades desenvolvidas em uma sequência didática a partir da produção artística de Vinícius de Moraes, destacando-se dois de seus sonetos "Soneto da fidelidade" e "Soneto do maior amor", ratificando a importância do trabalho interdisciplinar desenvolvido pelo Programa Institucional de Bolsas de Iniciação à Docência, PIBID/ Capes-Uni-FACEF 2018-2019, envolvendo as duas licenciaturas: Letras e Matemática, sendo aqui apresentadas apenas aquelas relativas a Português.

Para compor essa sequência didática, retomamos e aprofundamos os elementos do gênero lírico, contemplando a relação entre os recursos linguísticos e os efeitos de sentidos que afloram do texto a partir desse arranjo e que conduzem o discente à reflexão sobre os temas propostos: o amor e a amizade nas relações de convívio, podendo ser materializados na proposta de produção de texto.

Ao longo das atividades desenvolvidas, foi possível observar, que apesar de uma certa resistência quanto ao estudo do gênero lírico dentro da sala de aula, quando o aluno é motivado à leitura e compreensão do poema, percebe a atemporalidade desses textos, que trazem à reflexão os temas que 
constituem a condição humana, entregando-se ao encanto e sensibilidade que o gênero desperta. Trabalhar com literatura e poder ratificá-la a partir de nomes como o de Vinícius de Moraes, é inspirador e esclarecedor para nós futuros docentes.

\section{REFERÊNCIAS}

BOSI, Alfredo. História concisa da Literatura Brasileira. São Paulo: Cultrix, 2. ed. 1970.

CANDIDO, Antonio. O estudo analítico do poema. 5. ed. São Paulo: Humanitas, 2006, p. 61-94.

CASTELlO, José. Vinicius de Moraes - o poeta da paixão. São Paulo: Companhia das Letras, 1997.

CARA, Salete de Almeida. A poesia lírica. 3. ed. São Paulo: Ática, 1989.

CEREJA, William Roberto e MAGALHÃES, Tereza Cochar. Literatura brasileira. São Paulo: Atual, 1995.

DOLZ, J; NOVERRAZ, M.; SCHNEUWLY, B. Sequências Didáticas para o oral e a escrita: apresentação de um procedimento. In: Gêneros orais e escritos na escola. Tradução e organização Roxane Rojo e Glais Sales Cordeiro. Campinas, SP: Mercado de Letras, 2004, p. $81-108$.

KAYSER, Wolfgang. Análise e interpretação da obra literária. 6. Ed. Revisão Paulo Quintela. São Paulo: Martins Fontes, 1976

MORAES, Vinicius. Antologia poética. São Paulo: Lje, 1981.

PAZ, Octávio. Signos em rotação. 3. ed. São Paulo: Perspectiva, 1996.

SOARES, Angélica. Gêneros literários. 2. ed. São Paulo: Ática, 1993. 


\title{
EDUCAÇÃO E ACOLHIMENTO: UTILIZANDO A EDUCAÇÃO AFETIVA COMO FORMA DE TRANSFORMAÇÃO SOCIAL
}

\author{
SILVA, Juliano Aparecido da \\ Pós-Graduado em Tecnologias na Aprendizagem - Senac São Paulo \\ juliano.asilva@sp.senac.br \\ SILVA, Fernanda Ferro da \\ Pós-Graduada em Gestão da Educação a Distância - UFF \\ fernanda.fsilva@sp.senac.br
}

\section{INTRODUÇÃO}

Ao falarmos sobre educação podemos nos remeter a vários documentos, um deles é a Constituição Federal de 1988 que preconiza em seu artigo $6^{\circ}$ que dentre os direitos sociais, a Educação é o primeiro deles. Se é direito, então todos deveriam usufruir da melhor forma possível.

Segundo MORAES (1998, p.181), "direitos sociais são as garantias fundamentais do homem, são verdadeiras liberdades positivas, de observância obrigatória em um Estado Social de Direito", além disso, esses direitos tem a finalidade de proporcionar a melhoria de condições de vida aos que não possuem recursos dentro de uma perspectiva de concretização da igualdade social.

Ainda, conforme CARVALHO (2003, p.10), ao definir os direitos sociais os revela como aqueles que "garantem a participação na riqueza coletiva". Assim, como nos clareia FERREIRA (2010, p. 33), "constata-se que a Educação como direito social busca garantir o direito à igualdade".

Partindo da visão acima entende-se que a Educação, sendo o primeiro de todos os direitos sociais, tem grande relevância na transformação social, não sendo ela a solução para todos os problemas sociais de nosso país, mas sim a que ilumina o caminho para possíveis soluções.

Compreende-se também que a expectada transformação de nossa sociedade não será de um dia para outro e sim ao longo de alguns anos, os quais no momento não é possível mensurar.

Dentro deste contexto é preciso analisar o papel da educação na vida de adolescentes que estão cumprindo medida socioeducativa e que estão em privação de liberdade.

O perfil da população privada da liberdade no Brasil mostra que são majoritariamente jovens, afrodescendentes, de baixa escolaridade, de 
baixa qualificação profissional e para quem falharam todas as instâncias anteriores de socialização como a família, a religião, a comunidade, a escola e as políticas públicas. (SILVA ,2018, p.12).

Interpretando o que nos diz Silva, vemos a necessidade da união das famílias, religiões, comunidades, escolas e políticas públicas para os primeiros passos desta caminhada de metamorfose. Assim discorrendo no presente artigo veremos: em Educação e Exclusão as mudanças apresentadas pela constituição de 88, medidas de punição que podem levar o educando a privação da liberdade. No item precariedades das escolas e falta de recurso a escola é apresentada como ponto de referência da comunidade, porém esquecida, não recebe recursos, deixando de ser atrativa tanto para o discente quanto para a comunidade que muitas vezes a depreda. Buscando um novo olhar para essa realidade, veremos em Educação como um ato amoroso, que a conexão entre os envolvidos revela o interesse de mudança e transformação social, convidando para uma participação relevante neste contexto, além do mais, o papel do educador é imprescindível na mediação da mudança que se espera alcançar.

A título de sugestão veremos em Metodologias ativas de aprendizagem que é possível conciliar conteúdo e acolhimento para uma formação transformadora. Não esquecendo a importância do vínculo comunitário como forma de fortalecer o território onde a escola está inserida.

\section{EDUCAÇÃO E EXCLUSÃO}

Nas últimas décadas passamos por muitas transformações em nosso cotidiano, muita coisa aconteceu após a promulgação da Constituição Federal de 1988, chamada de constituição cidadã, com seu advento muitos tiveram voz, idosos, crianças, adolescentes, negros, população LGBT+, população em situação de rua, etc. Neste contexto nascem vários códigos e estatutos que regulamentam a participação de todos na sociedade. Assim surge com muita veemência o termo Exclusão, usado sempre quando aquele que passou a ter voz com a nova carta magna é tolhido.

Muitas vezes essa exclusão acontece de forma silenciosa, o que acontece com alguns educadores quando são proibidos em sala de aula de realizar análise de conjuntura política até mesmo em aulas de história.

Outra forma de exclusão acontece quando o educando é obrigado a esquecer tudo aquilo que aprendeu em casa, apagando aquilo que para ele tem muito valor para reaprender na forma em que a escola e/ou educador determina, como exemplo aprende-se regra de três nas saudosas brincadeiras de "casinha", no momento em que se faz bolinho de barro. 
O educando muitas vezes não se identifica com isso, o que o leva a ter reações negativas como: desinteresse pela tarefa, postura passiva ou distanciamento e com comportamento destrutivo, sendo este último aquele que o faz passar várias vezes pela sala do diretor, até o momento de desistir de ir à escola.

Acolhido por transgressores e disseminadores de mazelas sociais esse educando conhece autonomia, autoridade, empoderamento e inclusive a confiança, a partir disso começam a praticar pequenos delitos até a inclusão no sistema de privação de liberdade.

\subsection{Adolescentes em conflito com a lei}

O ECA (Estatuto da Criança e do Adolescente) apresenta no capítulo IV as medidas socioeducativas, dentre elas está a internação em estabelecimento educacional, caracterizada como medida privativa de liberdade, pautada pelos princípios de brevidade, excepcionalidade e respeito à condição peculiar de pessoa em desenvolvimento.

Após algumas mudanças, e com o ECA, crianças e adolescentes passaram a ser sujeitos de direitos reconhecidos e assegurados, e as entidades de abrigo ou internatos passaram a ter a preocupação e compromisso em priorizar o desenvolvimento destes sujeitos.

Uma das instituições que atendiam adolescentes infratores era a antiga FEBEM (Fundação do Bem-Estar do Menor) que ficou conhecida pelas fugas, rebeliões, denúncias de maus-tratos aos adolescentes, tortura e superlotação. Com o advento do ECA algumas alterações começam a acontecer. Após um projeto de lei ser aprovado em dezembro de 2006, essa instituição passa a ser chamada de Fundação CASA com uma significação bem mais apropriada de forma a apagar as manchas deixadas pela antiga FEBEM. O Centro de Atendimento Socioeducativo ao Adolescente (CASA) conta hoje com 149 centros socioeducativos.

Os adolescentes que estão em cumprimento de medida sócio educativa de privação de liberdade são frutos de um governo e sociedade que acredita na separação como símbolo de reparação, ou seja, se o jovem cometeu algo que o torna inapropriado para conviver em sociedade, então é melhor que ele se aparta desta "sociedade", fique isolado para refletir sobre seu erro.

Era comum em alguns anos letivos que o aluno ao praticar algum ato de indisciplina, fosse levado à diretoria e ali ficava até os pais irem buscálo, era a pedagogia da punição sendo colocada em prática. 
Portanto, o professor que atua na educação de jovens tem que ampliar o olhar para este público e saber que o que os caracterizam são 0 entusiasmo, a paixão, a força de vontade e que colocam toda a força a serviço de seus sonhos.

A questão sócio financeira caracteriza-se também como algo determinante no futuro deste público, jovens de classe média geralmente tem sua juventude prolongada em razão da entrada na universidade, diferente de um jovem de classe inferior que tem a juventude "reduzida" por ter que trabalhar e auxiliar a família nas despesas de casa.

Para estes, é um grande privilégio conseguirem a formação em escola técnica, o que justifica sua entrada cada vez mais cedo no mercado de trabalho.

Outros nem chegam a frequentar o Ensino Médio pois a necessidade de sobrevivência o faz automaticamente buscar formas de melhorar a renda da família, nem sempre a escolha é a via do emprego formal.

Diferentemente daquele jovem que entrará no "mundo adulto" após os 23 ou 24 anos, somente depois que obter graduação, pós-graduação, e muitas vezes tutelados pela família.

Há vários fatores que podem prejudicar a continuidade dos estudos como gravidez precoce, morte prematura dos pais etc. Essas questões vão delinear diferentes características e durações para a adolescência. É importante falar que o jovem vive um paradoxo que o angustia, em razão da cobrança dos adultos, exige-se destes um comportamento maduro com relação a algumas questões, e, ao mesmo tempo, julgam-no jovem demais para outras.

Dessa maneira, o adolescente fica sem saber como agir diante dos adultos, tendo em vista que não existem regras para considerá-lo "muito jovem" ou "quase adulto".

De modo geral, os adolescentes em conflito com a lei apresentam baixo desempenho e interesse pela escola e elevadas taxas de evasão escolar. (BAZON, 2013, p.2). É justamente essa evasão escolar que traz como consequência o aumento da vulnerabilidade do jovem, inclusive se fora da escola ele não conseguir uma inserção satisfatória no mercado de trabalho.

Sabemos que a baixa escolaridade prejudica a colocação em postos de trabalho melhor remunerados, e essa precariedade nas atividades laborais podem gerar insatisfação, desânimo e frustração no jovem que não concluiu seus estudos.

\subsubsection{PRECARIEDADE DAS ESCOLAS E FALTA DE RECURSOS}


Sabe-se que escola não é só prédio e sim uma comunidade, envolvendo alunos, professores, corpo administrativo, pais e comunidade ao entorno. Porém o prédio é a referência desta comunidade, pois ali é onde se reúnem.

Quando se fala de prédio inclui-se salas amplas, bibliotecas e salas de leituras atualizadas, salas com computadores, auditórios, salas mistas, salas agradáveis para os professores e corpo administrativo, refeitórios, todos com acesso para pessoa com deficiência. Muitos outros recursos importantes e necessários para o processo de aprendizagem.

Infelizmente a realidade é outra, de acordo com o "censo de 2017, $10 \%$ das escolas não possuem água, energia elétrica e esgoto. Somente $41,6 \%$ contam com rede de esgoto, e 52,3\% apenas com fossa. Apenas 46,8\% das escolas de ensino fundamental dispõem de laboratório de informática; $65,6 \%$ das escolas têm acesso à internet; em 53,5\% das escolas a internet é por banda larga". (Agência Brasil, 2018).

Existe ainda a necessidade de: a) melhorar as condições estruturais das escolas para que sejam espaço de inclusão e acolhimento, b) melhorar o salário do corpo docente e administrativo e c) conscientizar a população que a escola deve ser preservada por todos.

A falta de recursos materiais é um dos pontos que prejudica a permanência do aluno na escola, quando o espaço não oferece o mínimo de condições para se viver a aprendizagem, o ensino pode se tornar enfadonho, desmotivador. Adolescente gosta de ambientes acolhedores, que representam seus gostos particulares como por exemplo uma quadra de esportes, sala de informática, atividades lúdicas na biblioteca, espaços de convivência e interação.

Uma escola acolhedora se torna atrativa inclusive para a comunidade, que por consequência irá mantê-la, preservá-la, e se envolver com as atividades realizadas.

\section{EDUCAÇÃO AFETIVA E TRANSFORMAÇÃO SOCIAL}

Quando o processo educativo ocorre sem o estabelecimento de vínculos, sem a participação ativa do aluno, pode trazer frustração para educador e educando, além de evidenciar as desigualdades sociais que existem na escola.

Segundo SHELDRAKE (1991, p.114), conforme citado por SANTO (2007, p.32), "a existência de um campo morfogenético no qual a evolução decorrente do aprendizado de cada espécie é "arquivada", os novos membros já nascem com tal aspecto evolutivo", ou seja, uma vez acolhido, o 
educando terá uma postura diferente consigo, com seus familiares e assim sucessivamente.

SANTO ainda diz que "a realidade de amor, além de nos conduzir a uma perspectiva de possibilidades de conexões, também deixa patente 0 mistério da liberdade, presente em cada ser humano".

Trazendo para o foco de nossa pesquisa, essa parceria ou conexões no processo educativo, significa muito para o aluno que passa a se ver como o eixo de si mesmo, se sente mais motivado a construir seu conhecimento, tem uma postura aberta em relação ao trabalho do professor.

A constituição de tal processo como um ato amoroso só poderá ocorrer quando o educador pautar seu trabalho na reflexão, na parceria, na troca de experiências e no respeito pela história de vida do aluno, onde há presença destes princípios há alunos confiantes e estimulados a progredir em seus estudos.

$\mathrm{Na}$ contemporaneidade o ofício do professor deixou ser uma simples passagem de conhecimento, o que Paulo Freire chama de educação bancária, e sim uma incumbência de contágio aos adolescentes no tocante a valores, cidadania e sujeitos de transformação da sociedade.

A vinculação à escola desponta como um dos fatores protetivos para o engajamento dos alunos, além da questão preventiva que essa ligação produz.

Para ALVES (2010, p.15) "o conhecimento sem compaixão não tem valor, pois a compaixão cria a bondade, e viver em uma sociedade em que não existe a bondade é muito ruim."

É preciso investir tempo para conversar com os alunos, saber sobre sua vida, seus sonhos. A qualidade dessas vivências escolares constrói o elo necessário a prevenção de evasões, conflitos e desvio de conduta.

\subsection{PAPEL DO EDUCADOR}

A postura do educador que acredita na pedagogia do afeto e na constituição de vínculos com os alunos é diferente, ele se preocupa em preparar aulas mais participativas, se debruça no conhecimento das peculiaridades de cada aluno.

Professor acolhedor, mediador, prática pedagógica, metodologias ativas nesse contexto ganham relevância pois, precisam desempenhar um papel de curadores e desenvolvedores de percursos de aprendizagem para que os estudantes construam os seus questionamentos, investigações, práticas e avancem na aprendizagem. 
FERREIRA, (2010, pg.35), nos apresenta que "a Constituição deixa claro que o objetivo dos direitos sociais, ou seja, da educação, é o bemestar e a justiça social, a fim de assegurar a todos existência digna...", com isso fica claro que um dos objetivos do ato de educar é refletir essa "dignidade social".

A partir deste apontamento analisamos que o papel da educação vai além, e a ação e postura do educador que acolhe e se preocupa com o aluno pode interferir no seu cotidiano escolar.

Surgem então desafios ao educador como: estar atualizado, conhecer e se familiarizar com as novas tecnologias de informação e comunicação (TICs) ou seja, estar em constante formação.

Disso surge uma questão: como trabalhar autonomia, ética, dignidade nos bancos escolares?

De acordo com STAINBACK (1996, pg. 342)," existem três reações comportamentais gerais para um aluno durante períodos de aula ou tempo envolvido nos estudos: voltado para a tarefa e envolvido na aprendizagem, desinteressado pela tarefa e sentado passivamente ou distanciado, desinteressado pela tarefa e com comportamento destrutivo".

Considerando as referidas reações, se torna interessante realizar uma avaliação prévia do conhecimento preexistente dos alunos, desta forma obtém-se o interesse dele na aprendizagem, reduzindo ou eliminando as duas últimas reações.

Após referida avaliação prévia pode se utilizar de metodologias ativas de aprendizagem.

Quando o professor demonstra interesse pelo aluno, principalmente nos momentos de dificuldade é interpretado pelos educandos como cuidado, atenção e estima. Isso faz com que a relação se torne forte, de forma que o educador poderá aconselhar, elogiar e incentivar sempre que for necessário.

Essa proximidade relacional, pautada em respeito recíproco, viabiliza o vínculo escolar e pode mudar a trajetória dos alunos.

\section{METODOLOGIAS ATIVAS DE APRENDIZAGEM}

São práticas e ou metodologias pedagógicas onde o aluno se responsabiliza por seu aprendizado, desta forma ele se torna autônomo e participativo. 
O ensino por projetos é um exemplo de metodologia ativa, nele o discente busca solucionar um problema, hipotético ou não, até solução adequada. Concomitante pode se aplicar a prática da sala de aula invertida, situação que o educando recebe online o conteúdo, estudando em casa e um período em sala de aula para tirar dúvidas e interagir com os demais na busca da solução do projeto.

$\mathrm{Na}$ atualidade vivemos o paradigma de atrair os jovens, na sua maioria voltados para as redes sociais, utilizando as metodologias ativas de aprendizagem podemos buscar o envolvimento e a atenção dos púberes possibilitando um maior acúmulo de conteúdo descoberto e assim uma educação afetiva.

Realizando uma avaliação prévia do conhecimento do aluno valoriza-se aquilo que ele traz como bagagem de conhecimento, que na maioria das vezes é o que aprendeu com o avô, avó, mãe, pai ou até mesmo com alguém que ele considera importante, sendo que boa parte dos jovens em situação de vulnerabilidade não tem contato com familiares de primeiro grau, são criados por parentes e ou vizinhos e conhecidos.

$\mathrm{Na}$ aprendizagem por transmissão de conteúdo pode acontecer de o aluno ter que esquecer seus conhecimentos prévios o que o torna apático ao que está sendo transmitido, levando-o a comportamentos destrutivos. Neste momento se o professor se mostrar preocupado com este conhecimento ele agirá de maneira acolhedora e afetiva, trazendo o discente para o mundo da ideia.

Surge a preocupação de descobrir o que é mais importante o conteúdo ou o vínculo, nota-se que entre os dois não existe superioridade tampouco inferioridade, na verdade o que se estabelece é complementaridade, onde um necessita do outro para obter sucesso e ou chegar ao objetivo.

Exemplificando: $\mathrm{Na}$ antiguidade, o conhecimento, os valores e atitudes eram passados de pai para filho, existindo assim um vínculo afetivo e sempre uma preocupação hereditária em se transmitir o conteúdo.

Tendo cada um seu devido valor, porém juntos os seus efeitos serão de maior resultado configurando em transformação humana e social.

\subsection{PAPEL DA FAMÍLIA E SOCIEDADE}

Segundo CHALITA (2001, p.17) "por melhor que seja uma escola, por mais bem preparados que estejam seus professores, nunca a escola vai suprir a carência deixada por uma família ausente." 
Em relação ao jovem, muitas vezes a escola o obriga a ser 0 melhor em praticamente tudo, essa mesma escola que estagnou no tempo e não se preparou para lidar com a diversidade.

Ainda segundo CHALITA (2001, p.17) "Os jovens por muitas vezes são rotulados como malcriados, rebeldes, perdidos, preguiçosos, imorais, sem iniciativa, e que precisa aprender a "ser gente". O educador ao ter contato com este jovem precisa enxergá-lo como pessoas ávidas de vida, entusiasmados, curiosos, inteligente e com histórias de vida repletas de lutas e potencial.

A família é o lugar onde se vivencia as afetividades, sendo este âmbito responsável pelas emoções, ligado aos sentimentos. Somente vivenciando esta dimensão de forma saudável é possível preparar o indivíduo emocionalmente para convivências salutíferas por toda a sua existência.

Assim o papel da família em concomitância com o da escola está em ajudar o educando a identificar seus impulsos, se conhecer controlando seus pontos fortes e fracos e se adaptar nos mais diferentes cenários e se relacionar com vários tipos de cidadãos.

Para uma educação acolhedora o educando precisa se sentir parte do processo, ter vez e voz, se conscientizar de que é responsável pelo que faz e pelas consequências do que fez. Que pode errar, porém deve aprender com o erro. Que deve entender quando um amigo e ou professor erra, que juntos todos são responsáveis pela aprendizagem, sempre um fortalecendo o outro.

Para facilitar este entendimento torna se interessante criar uma comunidade de aprendizagem, onde todos são parceiros, mediados pela comunidade escolar.

O primeiro conjunto de atividades no processo de construção da comunidade deve estar concentrado em torno do objetivo de fazer com que os alunos se sintam bem-vindos e conheçam uns aos outros. O próximo passo é o estabelecimento de um contrato social, três tipos de comportamentos devem ser considerados neste contrato: 1) regras de conduta interpessoal humanas, respeitosas, interessadas e solidárias; 2) regras de comportamentos positivos e produtivos durante as atividades de aprendizagem diárias; 3) diretrizes de condução da aprendizagem diária. (STAINBACK,1996, $\mathrm{pg}, 143)$.

Nota-se que a maioria dos adolescentes buscam uma mudança, para tanto querem abandonar o território, sendo que se forem acolhidos por uma comunidade participativa e que se preocupa com as dificuldades daquele entorno, tais jovens sentem o desejo de permanecerem e assim se tornam protagonista desta mudança. 


\section{CONSIDERAÇÕES FINAIS}

Sem a pretensão de concluir o que foi dito até então, é importante ressaltar que 0 ato de ensinar pode ser complexo e por vezes árduo para 0 professor, se não houver relação social ou vínculos com o aluno poderá sim se transformar em algo mecânico, pesaroso, que converte as diferenças culturais em desigualdades escolares.

O professor que opta por um processo de aprendizagem afetiva, irá desenvolver técnicas de ensino que facilitarão a vida dos estudantes, que muitas vezes vão à escola após o dia de trabalho, e o cansaço físico e mental pode atrapalhar seu aprendizado.

Assim este educando se sentirá acolhido e reconhecido tanto por seu esforço em busca do conhecimento quanto por sua dedicação em transformar a sociedade em um lugar melhor, ao se sentir parte da comunidade de aprendizagem ele terá muito mais vontade de estar ali, com uma postura pró ativa e estimulada.

Vale ressaltar que o educador não conseguirá sozinho realizar essas conexões, é preciso que toda a comunidade escolar esteja vinculada neste processo de acolhimento, sendo ali o primeiro território a ser transformado.

A transformação social tão almejada no atual contexto só começará a surgir quando todos entenderem que a educação não é apenas o processo de transmissão de conhecimento e sim uma ferramenta fortalecida pelos vínculos criados através do acolhimento e valorização do ser humano.

\section{REFERÊNCIAS}

AGÊNCIA BRASIL. Censo aponta que escolas públicas ainda têm deficiências de infraestrutura. Disponível em: http://agenciabrasil.ebc.com.br/educacao/noticia/2018-01/censo-aponta-queescolas-publicas-ainda-tem-deficiencias-de-infraestrutura. Acesso em: 9. jul.19.

ALVES, Rubem. A pedagogia dos caracóis. Campinas, SP: Verus, 2010.

BAZON, Marina Rezende; SILVA, Jorge Luiz da; FERRARI, Renata Martins. Trajetórias Escolares de Adolescentes em conflito com a Lei. Educação em Revista. Belo Horizonte, v.29/n.02. p.175-199. jun.2013. Disponível em: http://www.scielo.br/pdf/edur/v29n2/08.pdf> Acesso em 15.jul.19. 
BELLAN, Zezina Soares. Andragogia em ação: como ensinar adultos sem se tornar maçante. Santa Bárbara d’Oeste, SP: SOCEP Editora, 2005.

BRASIL. Congresso Nacional. Lei Federal n 9.394. Lei de Diretrizes e Bases da Educação Nacional. Brasília, 20 de dezembro de 1996.

Estatuto da Criança e do Adolescente. Disponível em: <http:www.planalto.gov.br/ccivil_03/leis/l8069.htm.> Acesso em 15.jul.19.

CARVALHO, J.M. Cidadania no Brasil: o longo caminho. Rio de Janeiro: Civilização Brasileira, 2003.

CHALITA, Gabriel. Educação: a solução está no afeto. São Paulo: Editora Gente, 2001.

FERREIRA, L. A. M; Estatuto da criança e do adolescente e o professor: Reflexos na sua formação e atuação. 2ª . ed. Brasil: Cortez, 2010.

FUZARO, S. R. C. Comportamento: Família e a educação da afetividade. 0 São Paulo, São Paulo, 10/2018. Disponível em: http://www.osaopaulo.org.br/colunas/familia-e-a-educacao-da-afetividade.

Acesso em: 8 jul. 2019.

LUCKESI, C.C. O que é mesmo o ato de avaliar a aprendizagem? Pátio. Porto alegre: ARTMED. Ano 3, n. 12 fev. /abr. 2000. Disponível em:< file://C:/Users/Usuario/Downloads/4-o-que-e-mesmo-o-ato-de-avaliar-

aprendizagem.pdf.> Acesso em 08 mai.2019.

MORAES, A. de. Direito Constitucional. São Paulo: Atlas, 1998.

O SÃO PAULO. Família e a educação da afetividade. Disponível em: http://www.osaopaulo.org.br/colunas/familia-e-a-educacao-da-afetividade.

Acesso em: 8 jul. 2019.

ROSE, Mike. De volta à escola: porque todos merecem uma segunda chance na educação. São Paulo: Editora Senac São Paulo; Rio de Janeiro: Senac Nacional, 2005.

SANTO, Ruy Cezar do Espirito Santo. Autoconhecimento na formação do educador. São Paulo: Ágora, 2007.

SILVA, Roberto da. Didática no cárcere II: entender a natureza para entender o ser humano e o seu mundo. São Paulo: Giostri Editora, 2018.

STAINBACK, Susan; STAINBACK, William; Inclusão: Um guia para educadores. Primeira. ed. Brasil: Artmed, 1996. 


\title{
EDUCAÇÃO SOCIAL: Um olhar diferente
}

\author{
GARCIA, Allyson da Silva \\ Graduando - Uni-FACEF \\ SILVA, Messias Rogério Faria da \\ Graduando - Uni-FACEF \\ GERA-BEIRO, Adriana Aparecida Silvestre \\ Docente - Uni-FACEF
}

\section{INTRODUÇÃO}

A Educação Social está comprometida com o desenvolvimento biopsicossocial dos indivíduos, com o bem-estar e o amadurecimento social e com a qualidade de vida. Para tanto, é necessário levar em consideração as mudanças referentes à concepção política, cultural, económica e educacional, assim como às suas consequências no contexto social. Baseando-se em tal perspectiva, a Coordenação de Aperfeiçoamento de Pessoal de Nível Superior (CAPES) tem implantado programas que têm como ponto de partida a realidade social, cultural e política da sociedade. Dois desses programas se referem ao aperfeiçoamento da formação de docentes: o Programa Institucional de Bolsa de Iniciação à Docência (PIBID) e o Programa de Residência Pedagógica.

\section{EDUCAÇÃO SOCIAL}

Educação é o ato de educar, de instruir, é polidez, disciplinamento. Já no sentido formal, educação (do latim educations) é todo o processo contínuo de formação e de ensino-aprendizagem que faz parte do currículo dos estabelecimentos oficiais de ensino, sejam eles públicos ou privados.

No seu sentido mais amplo, educação significa o meio em que os hábitos, costumes e valores de uma comunidade são transferidos de uma geração para a geração seguinte, sendo que esta vai se formando através de situações presenciadas e experiências vividas por cada indivíduo ao longo da sua vida. O conceito de educação engloba o nível de cortesia, delicadeza e civilidade demonstrada por um indivíduo e a sua capacidade de socialização. Também é definida como um conjunto de ações e influências exercidas voluntariamente por um ser humano em outro, normalmente de um adulto em um jovem. Essas ações pretendem alcançar um determinado propósito no 
indivíduo para que ele possa desempenhar alguma função nos contextos sociais, econômicos, culturais e políticos de uma sociedade (PORTAL EDUCAÇÃO, s/d, s/p).

No sentido técnico, a educação é o processo contínuo de desenvolvimento das faculdades físicas, intelectuais e morais do ser humano, que o levam a se integrar melhor na sociedade ou no seu próprio grupo. No Brasil, de acordo com a Lei de Diretrizes e Bases (LDB/96), a Educação dividese em dois níveis, a educação básica e o ensino superior. A educação básica compreende a Educação Infantil, o Ensino Fundamental e o Ensino Médio. No processo educativo em estabelecimentos de ensino, os conhecimentos e as habilidades são trabalhados em crianças, jovens e adultos sempre com o objetivo de desenvolver o raciocínio dos alunos, ensinar a pensar sobre diferentes problemas, auxiliar no crescimento intelectual e na formação de cidadãos capazes de gerar transformações positivas na sociedade. A educação não se limita apenas a normas morais e intelectuais, mas também pode estar relacionada com o aspecto físico, como é o caso da Educação Física (PORTAL EDUCAÇÃO, s/d, s/p).

Vale salientar também que discorrer sobre educação nos remete a questão da relação entre desenvolvimento cognitivo e aprendizagem. Jean Piaget e Lev Vygotsky, dois teóricos cognitivistas e interacionistas, destacamse por terem estudado esta relação.

Vygotsky (1988) propõe que desenvolvimento e a aprendizagem caminham juntos e têm início logo após o nascimento da criança, mostrando que o aprendizado deve estar conectado ao desenvolvimento do aprendiz. Aprendizado não é desenvolvimento; entretanto, 0 aprendizado adequadamente organizado resulta em desenvolvimento mental e coloca em movimento vários processos de desenvolvimento que, de outra forma, seriam impossíveis de acontecer. Assim, o aprendizado é um aspecto necessário e universal do processo de desenvolvimento (VYGOTSKY, 1988). Com esta afirmação, Vygotsky (1988) esclarece que apesar de serem conceitos diferenciados, aprendizado e desenvolvimento estão inter-relacionados e que um depende do outro para a formação do indivíduo. O referido autor apresenta conceitos inovadores para definir o aprendizado da criança e sua conexão com o desenvolvimento: nível de desenvolvimento real (NDR), que são as funções mentais da criança que se estabelecem como resultados de certos ciclos de desenvolvimento já completados e o nível de desenvolvimento potencial (NDP), que é todo o potencial que a criança tem para aprender e se desenvolver quando mediada por outra pessoa (VYGOTSKY, 1988). Portanto, Vygotsky (1988) sustenta a premissa de que o professor deve mediar o processo de aprendizagem da criança, fazendo emergir sua zona de desenvolvimento proximal (ZDP), a qual é caracterizada pela distância entre NDR e NDP. 
Em contraponto, Piaget propõe que o processo de aprendizagem é independente do processo de desenvolvimento da criança. Inicialmente ocorre a maturação, que é pré-requisito para que a aprendizagem aconteça, e somente depois ocorre o aprendizado de fato, chegando-se à conclusão de que são necessários maturação e desenvolvimento para haver aprendizagem (PIAGET apud VYGOTSKY, 1988).

Piaget também se destaca por ter estudado os processos individuais dificilmente observáveis, como processamento de informações, estilos de pensamento e conhecimento (MIZUKAMI, 1996). Como resultado de seus estudos, o teórico estabeleceu períodos do desenvolvimento cognitivo da criança, dividindo-os em quatro: período sensório-motor (0-2 anos), período pré-operatório (2-7 anos), período operatório-concreto (7-11/12 anos) e período operatório-formal (11/12 anos em diante).

O período pré-operatório é caracterizado pelo surgimento da linguagem. A possibilidade de falar habilita um esquema mental diferente, no qual a função simbólica é primordial. A criança utiliza símbolos para representar os objetos, os lugares e as pessoas. Ela entende que as palavras são usadas para designar as coisas que estão ao redor. Além disso, a criança assume sua identidade, apesar das mudanças pelas quais seu corpo passa. Ela reconhece a si mesma, mesmo crescendo e mudando. A mesma coisa acontece em relação à mãe, ao pai e aos irmãos. A criança os identifica como tais, mesmo que a aparência se altere. Pouco a pouco, a criança adquire a capacidade de se colocar no lugar dos outros. Apesar disso, a criança ainda lida com o mundo a partir de si mesma, ou seja, o egocentrismo ainda está muito presente durante toda essa fase. Ela acha que tudo foi feito e pensado para que ela o use. Isso dificulta bastante o pensamento abstrato (PAPALIA e FELDMAN, 2013).

Piaget apud Papalia e Feldman (2013) pontua que o animismo é outra característica do pensamento pré-operatório, ou seja, a criança atribui intencionalidade a tudo e, portanto, todas as coisas são animadas. Os objetos são maus porque machucam ou a lua é boa porque aparece no céu à noite. Nessa fase, a criança tende a simplificar as explicações de tudo que acontece ao seu redor, seu pensamento é baseado em associações simples. Além disso, seu pensamento funciona por analogia, estabelecendo relações comparativas entre dados, buscando similaridades e diferenças e tirando conclusões. Nesse período, a criança forma conceitos e não se preocupa em descobrir a veracidade ou falsidade de tais conceitos. Por exemplo, se uma criança vir a mãe arrumando a casa porque espera visitas, sempre que a ver arrumando a casa de novo vai esperar convidados. Também é a fase do "por que". A criança está descobrindo o mundo através dos adultos e o porquê das coisas permite que ela obtenha respostas. Nas perguntas são evidenciadas as características do pensamento lógico. A criança pode perguntar sobre temas simples e 
cotidianos ou sobre temas complexos como, por exemplo, a morte ou a sexualidade. Seu pensamento é irreversível, o que faz com que a criança não consiga conceber duas categorias em uma. Por exemplo, sua mãe não pode ser a filha da sua avó exatamente porque é sua mãe (PAPALIA e FELDMAN, 2013).

Uma vez definido o conceito de Educação e a relação que existe entre desenvolvimento cognitivo e aprendizagem, pode-se agora discorrer sobre dois projetos relacionados à Educação e à formação de professores, os quais trabalham diretamente com a educação de crianças, jovens e adultos desde a Educação Infantil até o Ensino Médio: o PIBID (Programa Institucional de Bolsa de Iniciação à Docência) e a Residência Pedagógica. O objetivo deste artigo é apresentar os dois programas, traçando um paralelo sobre suas contribuições em relação à formação dos futuros docentes.

O PIBID é um programa de incentivo e valorização do magistério e de aprimoramento do processo de formação de docentes para a Educação Básica, vinculado a Diretoria de Educação Básica Presencial - DEB - da Coordenação de Aperfeiçoamento de Pessoal de Nível Superior - CAPES. Este programa oferece bolsas para que alunos de licenciatura exerçam atividades pedagógicas em escolas públicas de Educação Básica, contribuindo para a integração entre teoria e prática, para a aproximação entre universidades e escolas e para a melhoria de qualidade da educação brasileira. Para assegurar os resultados educacionais, os bolsistas são orientados por coordenadores de área - docentes das licenciaturas - e por supervisores docentes das escolas públicas onde exercem suas atividades (CAPES, 2013).

O Programa Residência Pedagógica é uma das ações que integram a Política Nacional de Formação de Professores e tem por objetivo conduzir ao aperfeiçoamento da formação prática nos cursos de licenciatura, promovendo a imersão do licenciando na escola de Educação Básica, a partir da segunda metade de seu curso. Essa imersão deve contemplar, entre outras atividades, regência de sala de aula e intervenção pedagógica, acompanhadas por um professor da escola com experiência na área de ensino do licenciando e orientada por um docente da sua Instituição formadora (CAPES, 2018).

A Residência Pedagógica, articulada aos demais programas da Capes, compõe a Política Nacional, a qual tem como premissas básicas o entendimento de que a formação de professores nos cursos de licenciatura deve assegurar aos seus egressos, habilidades e competências que thes permitam realizar um ensino de qualidade nas escolas de Educação Básica.

\section{QUAL A DIFERENÇA ENTRE O PIBID E A RESIDÊNCIA PEDAGÓGICA?}


Entre as mudanças anunciadas pelo Ministério da Educação (MEC), com a nova política de formação de professores, está a Residência Pedagógica. O novo programa faz parte da modernização do Programa Institucional de Bolsas de Iniciação à Docência (PIBID), que tem como objetivo o apoio a futuros professores que fazem licenciatura ou pedagogia.

O PIBID tem por finalidade fomentar a iniciação e a qualificação à docência, contribuindo para o aperfeiçoamento da formação de docentes em nível superior e para a melhoria da qualidade da Educação Básica pública brasileira. O Projeto incentiva a inserção dos licenciandos do $1^{\circ}$ e do $2^{\circ}$ ano em escolas públicas de Educação Básica desde o início de sua formação acadêmica por meio de concessão de bolsas. O PIBID recebe apoio da Capes, sendo desenvolvido por grupos de licenciandos da IES sob supervisão de professores de Educação Básica e orientação de professores das IES (coordenadores de área) (CAPES, 2013).

Já a Residência Pedagógica tem como principal princípio a coordenação entre a faculdade (instituição formadora) e a secretaria municipal ou estadual e seu foco são os alunos de $3^{\circ}$ e de $4^{\circ}$ ano da graduação. $O$ programa tem os objetivos de: aperfeiçoar a formação dos discentes de cursos de licenciatura, por meio do desenvolvimento de projetos que fortaleçam a prática e que levem o licenciando a exercitar de forma ativa a relação entre teoria e prática docente; reformular a formação prática nos cursos de licenciatura, tendo por base a experiência da residência pedagógica; fortalecer, ampliar e consolidar a relação entre a IES e a escola, promovendo sinergia entre a entidade que forma e a que recebe o egresso da licenciatura e estimulando o protagonismo das redes de ensino na formação de professores; e promover a adequação dos currículos e propostas pedagógicas dos cursos de formação inicial de professores da Educação Básica às orientações da Base Nacional Comum Curricular (BNCC) (CAPES, 2018).

De acordo com o MEC, a semelhança entre o PIBID e a Residência Pedagógica reside na proximidade que ambos os programas proporcionam aos estudantes de licenciatura com a escola. Porém, o primeiro proporciona uma aproximação da realidade escolar, enquanto o segundo proporciona uma imersão na realidade escolar.

\section{TANGRAN: Relato de uma experiência}

Para exemplificar como é o trabalho realizado pelos bolsitas nesses projetos, mostra-se a seguir uma atividade que foi desenvolvida por dois licenciandos em Matemática, enquanto bolsistas do subprojeto Matemática PIBID/Uni-FACEF. Este subprojeto tem como objetivos: proporcionar melhoria da qualidade do ensino de Matemática de Franca e região; proporcionar o 
desenvolvimento da iniciação à docência de alunos - futuros professores, do curso de licenciatura em Matemática, para atuarem em escolas de Educação Básica - Ensino Fundamental, propiciando momentos de reflexão crítica aos professores de Matemática atuantes nas escolas sobre a prática docente e fomentando ações que levem os alunos das escolas a construírem conhecimentos matemáticos; desenvolver experiências metodológicas e práticas docentes de caráter inovador que se orientem para a superação de problemas identificados no processo ensino-aprendizagem da Matemática; explorar aspectos metodológicos direcionados para o ensino da Matemática por meio do uso de materiais manipuláveis e de jogos, de modo a dar significado aos conteúdos matemáticos, dinamizando a aprendizagem; discutir e planejar atividades didáticas, incorporando o uso de recursos tecnológicos no contexto de ensino e aprendizagem de conceitos matemáticos; incentivar 0 diálogo entre os futuros professores e professores atuantes na rede pública, colaborando para a reflexão sobre alternativas de formas de trabalho que visem à melhoria do ensino da Matemática; elevar a qualidade das ações acadêmicas voltadas à formação inicial de professores nos cursos de Licenciatura em Matemática.

Levando em consideração os objetivos expostos acima, os licenciandos do subprojeto de Matemática buscam elaborar, desenvolver e aplicar jogos e atividades diferenciados como recursos motivacionais para aprender conteúdos e conceitos matemáticos.

Relata-se, então, aqui a experiência desses dois bolsistas na aplicação de uma atividade de construção do Tangran com alunos de $6^{\circ}$ anos de uma escola da rede pública estadual da cidade de Franca-SP.

O Tangram é um quebra-cabeça formado a partir de um quadrado que é decomposto em sete figuras geométricas, sendo elas cinco triângulos, um quadrado e um paralelogramo. Com o Tangram é possível montar mais de 1.700 figuras, sendo ótimo para o desenvolvimento do raciocínio e da criatividade. Além disso, pode-se utilizá-lo para desenvolver várias habilidades, como reconhecimento de figuras geométricas, área, perímetro e identificação, semelhança de triângulos, ângulos e retas paralelas.

Figura 1 - Tangran 


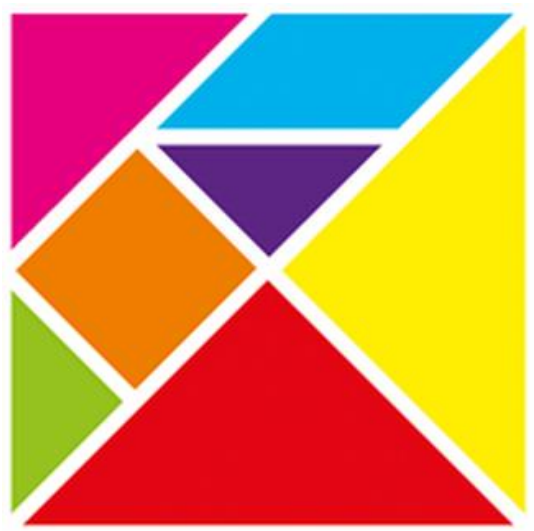

Fonte: GOOGLE

$\mathrm{Na}$ atividade realizada pelos bolsistas do PIBID, inicialmente, foi contada a história do Tangran para que os alunos conhecessem sua origem. Logo após, foi explicado aos alunos quais conteúdos e conceitos geométricos estão envolvidos na sua construção. Posteriormente, foram entregues aos alunos papel cartão e tesoura para que cada um confeccionasse seu próprio Tangran. Para tanto, um dos bolsistas foi explicando e desenhando na lousa, passo a passo, cada uma das figuras geométricas, de acordo com as medidas preestabelecidas, para a construção do Tangran e os alunos foram desenhando-as no papel cartão e recortando-as. Depois que cada aluno construiu seu Tangran, o bolsista explicou as características e propriedades dos polígonos: quadrado, triângulo e paralelogramo. Para familiarizar os alunos com as figuras, os bolsistas solicitaram que eles construíssem as mais variadas figuras utilizando as peças geométricas do Tangram, por meio da justaposição.

Durante a realização da atividade, os alunos mostraram interesse pela atividade e verificou-se, através dos comentários dos mesmos, que conseguiram compreender as características e propriedades dos polígonos, assim como, como estes são utilizados na construção de figuras.

\section{CONSIDERAÇÕES FINAIS}

O PIBID (Programa Institucional de Bolsa de Iniciação à Docência), assim como o Residência Pedagógica são programas que possibilitam aos bolsistas a realização pessoal e a qualificação e aperfeiçoamento profissional dos licenciandos. Sendo assim, enriquecem e contribuem para o reconhecimento, cada vez mais cedo, ainda durante a formação inicial, sobre o papel e a identidade profissional do professor. Para tanto, têm como ponto de partida a realidade social, cultural e política da sociedade. Sendo assim, os conhecimentos adquiridos na universidade vão permitir que os licenciandos articulem teoria e prática, de forma a potencializar a atitude reflexiva, crítica e criativa, tendo sempre a educação como campo de pesquisa contínua. 
As atividades desenvolvidas proporcionam a interação com 0 meio escolar, mostrando os obstáculos que os futuros professores enfrentaram. Esse acompanhamento em sala de aula mostra-se necessário para se obter maior aproximação do alunado e, assim, alcançar melhores resultados.

\section{REFERÊNCIAS}

COORDENAÇÃO DE APERFEIÇOAMENTO DE PESSOAL DE NÍVEL SUPERIOR - CAPES. Diretoria de formação de professores da Educação Básica - DEB, Relatório de gestão PIBID. Brasília, 2013. Disponível em: https://www.capes.gov.br/images/stories/download/bolsas/1892014-relatorioPIBID.pdf. Acesso em: 27 ago. 2019.

. Programa de Residência Pedagógica. Brasília, 2018. Disponível em: $\quad$ https://www.capes.gov.br/educacao-basica/programa-residenciapedagogica. Acesso em: 27 ago. 2019

MIZUKAMI, Maria da Graça Nicoletti. Ensino: as abordagens do processo. São Paulo: EPU, 1996.

PAPALIA, Diane E.; FELDMAN, Ruth D. Desenvolvimento humano. $12^{\mathrm{a}}$ ed., 2013.

PORTAL EDUCAÇÃO. Os reflexos da educação na sociedade contemporânea. Disponível em: https://www.portaleducacao.com.br/conteudo/artigos/concursos/os-reflexos-daeducacao-na-sociedade-contemporanea/55987\#. Acesso em: 30 ago. 2019, 10:40:30.

VYGOTSKY, Lev Semenovitch. Interação entre aprendizado e desenvolvimento. In:__. A formação social da mente: o desenvolvimento dos processos psicológicos superiores. Tradução de José Cipolo Neto. São Paulo: Martins Fontes, 1988. cap 6, p.89-104. 


\title{
REFLEXÕES SOBRE AMBIENTES VIRTUAIS DE APRENDIZAGEM E CONVERGÊNCIA DIGITAL NA EDUCAÇÃO A DISTÂNCIA
}

\author{
GALERANI, Thiago da Silva \\ Especialista - UFSJ \\ thiago@galerani.com.br
}

\section{INTRODUÇÃO}

A educação tradicional, no Brasil, historicamente caracterizada por aulas predominantemente expositivas, tem sido superada pouco a pouco.

Em uma era marca pelo uso irrefreado de recursos de Tecnologia da Informação e Comunicação (TIC's), pela globalização e pela necessidade de integração de múltiplos saberes, habilidades e competências, vislumbra-se uma forte tendência à adoção de práticas pedagógicas inovadoras. Trata-se de um reflexo das transformações e mudanças de paradigmas que a educação, como um todo, tem sofrido com o decurso do tempo.

O uso de TIC's na educação, por si só, não é sinônimo ou garantia de inovação: para que a inovação se concretize, é salutar que a própria metodologia de ensino se diversifique, não bastando simplesmente adotar recursos tecnológicos ou midiáticos como ferramentas de apoio pedagógico.

A EAD tem evoluído historicamente. Essa evolução é diretamente proporcional à evolução dos recursos tecnológicos de TIC's e à absorção desses recursos pela cultura.

A convergência digital que caracteriza a Web 2.0 revela-se cada vez mais presente: músicas, textos, filmes, jogos, imagens tornam-se acessíveis ao usuário por meio de qualquer dispositivo conectado à internet. Ao mesmo tempo, o usuário ganha a possibilidade de colaborar com a construção das informações, rompendo com o papel passivo de um mero expectador ou receptor de informações.

A convergência digital afetou não apenas a cultura dos usuários, mas o modo como atualmente são desenvolvidos os Ambientes Virtuais de Aprendizagem (AVA).

Assim, o presente estudo presta-se a investigar, com fulcro em pesquisa bibliográfica, como o fenômeno da convergência digital, caracterizado pelos recursos da Web 2.0, tem transformado as plataformas de aprendizagem e as práticas pedagógicas inerentes à Educação a Distância (EAD). 


\section{MÉTODO}

O presente estudo assenta-se em pesquisa bibliográfica.

A pesquisa bibliográfica realizada consistiu em levantamento, análise e interpretação de material bibliográfico (especialmente livros, artigos científicos e monografias) relacionado ao objeto de pesquisa, com o escopo de possibilitar a compreensão e ampliação quanto aos valores e conceitos inerentes ao objeto da pesquisa.

\section{A WEB 2.0 E O FENÔMENO DA CONVERGÊNCIA DIGITAL}

A Educação a Distância (EAD) não é um fenômeno absolutamente novo Brasil. De acordo com FARIA e SALVADORI (2010), pesquisas indicam que "antes de 1900 existiam anúncios em jornais de circulação no Rio de Janeiro, como o Jornal do Brasil, que ofereciam cursos profissionalizantes por correspondência."

A EAD tem evoluído historicamente alinhada de modo diretamente proporcional à evolução dos recursos tecnológicos de informação e comunicação (TIC's) e aos impactos gerados pelos aludidos recursos na dinâmica das interações sociais.

Atualmente, no campo educacional, vive-se a era da Web 2.0. Com a Web 2.0, a informação encontra-se espalhada pela rede mundial de computadores em vários formatos e mídias (textos, vídeos, músicas, etc), tornando-se acessível a qualquer pessoa que disponha de dispositivo eletrônico com acesso à internet (notebooks, desktops, smartphones, tablets, smart TV's, etc).

A Web 2.0 integra várias ferramentas e recursos, traduzindo-se em convergência digital, o que, de acordo com SOLOMON e SCHURM (2007), é extremamente positivo para as práticas educacionais:

As ferramentas da Web 2.0 proporcionam vantagens essenciais à educação em ciências uma vez que, promovem a comunicação, o trabalho colaborativo, partilha e troca de experiências, facilidade no trabalho de investigação científica, acesso rápido a informação, contribui para o aumento da literacia científica e espírito de equipa, desenvolve o espírito crítico e a criatividade

ALVES (2019) conceitua convergência digital como o fenômeno que "liga e conecta diversos dispositivos entre si, múltiplos suportes e 
linguagens, originando o fenômeno transmídia". Esse fenômeno transmídia consolidou-se no Brasil por meio de Web 2.0, de modo que, atualmente, crescem exponencialmente serviços de convergência multimídia, tais como serviços de assinatura de serviços online de provimento de filmes, músicas, jogos e outros. Assim, tornou-se inevitável, nesse cenário, a incorporação desses recursos de convergência aos Ambientes Virtuais de Aprendizagem, especialmente por meio da Web 2.0.

Insta destacar que o uso de mídias e tecnologias na educação não se restringe à educação a distância (EAD): é possível a utilização de mídias e recursos tecnológicos como ferramentas de apoio na educação presencial. Ademais, há registros de inúmeras pesquisas relatando experiências na prática de educação híbrida, que se caracteriza por verdadeira comunhão entre os recursos da educação presencial e da educação a distância.

SANTOS (2013,p. 40), explica que a educação híbrida seria a "convergência entre o virtual e o físico de espaços intersticiais, formando espaços conectados, onde se rompe essa cisão tradicional". Significa reunir os recursos de ambientes virtuais de aprendizagem e aqueles próprios da educação presencial, materializando a convergência de mídias para que se alcance a integração entre os sujeitos do processo educacional - tanto presencialmente quanto virtualmente.

Quanto à educação, seja ela presencial, a distância ou híbrida, é explícito que uma nova realidade social demanda aperfeiçoamento das práticas educacionais, afinal, as pessoas vivem no mundo e a elas a educação se dirige. Nesse sentido, FARIA (2014, p. 51) aduz que "um mundo em rede exige uma educação em rede para que esta não fique fora do mundo".

BRUCH e GOULART (2015, p. 11), ressaltam que o uso de mídias e tecnologias não tem o condão de resolver automaticamente o desafio de se construir educação de qualidade: "utilização de qualquer tecnologia no ensino não é garantia de melhora do aprendizado. O excesso de tecnologia pode até prejudicar o ensino. A forma (ambientes virtuais) não pode ser mais importante do que o conteúdo."

Da preleção acima transcrita, infere-se que o professor não deve priorizar a tecnologia ou a metodologia de ensino em detrimento do conteúdo: a prática pedagógica é tão importante quanto a profundidade dos ensinamentos desenvolvidos.

BURGARELLI (2011, p. 7), sobre a importância de incorporar novas mídias e recursos tecnológicos às práticas docentes, afirma:

É fundamental que se estabeleça dentro das instituições e dos
corações dos profissionais de educação verdadeira força
transformadora, para que, enfim, seja concretizada a implementação 
de novas práticas educacionais voltadas à formação do estudante do século XXI.

Depreende-se, da lição acima trasladada, que o autor sustenta a necessidade de promover de inovação no âmbito do ensino. Segundo o autor, a inovação ocorre por meio da ruptura com a pedagogia tradicional, aprimorando as técnicas e práticas e concretizando respostas pedagógicas à nova realidade. Os recursos de tecnologia da informação e comunicação afiguram-se como parte dessa resposta pedagógica, já que estão presentes no cotidiano do aluno, sendo irrefreável sua incorporação às metodologias na educação presencial, híbrida ou a distância. $O$ autor sugere, por fim, que é preciso contextualizar a prática pedagógica às experiências sociais que permeiam a vida dos estudantes.

\section{CONVERGÊNCIA DIGITAL E AMBIENTES VIRTUAIS DE APRENDIZAGEM}

A convergência digital proporcionada pela Web 2.0 impacta diretamente o desenvolvimento de Ambientes Virtuais de Aprendizagem (AVA), já que a construção dessas plataformas tende a atualizar-se em conformidade com os novos recursos tecnológicos disponíveis.

ANDRADE (2013, p. 117) ressalta que o uso de ferramentas integradas Web 2.0 em plataformas EAD propiciam maior colaboração e autonomia do aluno:

(...) quando o ambiente flexibiliza o contato com o mundo exterior, abrindo links para fora do ambiente virtual, onde o aluno entra em contato com outros sujeitos e opiniões distintas da sala de aula, o aprendizado, e consequentemente, a colaboração, autonomia e autoria do aluno, flui de maneira destacada e livre. Esta abertura da prática pedagógica ligada ao conceito da rede remete para a flexibilidade de um modelo organizacional tendencialmente não hierárquico, não centralizado e horizontal, caracterizado pela fluidez dos percursos e trajetórias da interação dos envolvidos no processo.

SANTAROSA et al. (2012) também salientam o potencial que a Web 2.0 representa para o impulsionamento do protagonismo educacional do aluno, já que, mais do que uma mera "sala de aula virtual", um Ambiente Virtual de Aprendizagem apresenta-se como um espaço colaborativo entre professores e alunos:

Contemporaneamente, os espaços de colaboração que emergiram com a Web conquistam novos instrumentos que possibilitam instituir 
um cenário de múltiplas partilhas e cooperação. Estratégias de mediação sociocultural passam a ser possibilitadas pelos servidores de vídeo e de transmissão de voz, revelando um empoderamento da Internet.

A Web 2.0 vem revelando um novo paradigma para a modelagem de interfaces para as tecnologias digitais de informação e de comunicação, um processo que mais do que aperfeiçoar a usabilidade de interfaces para Web, objetiva o desenvolvimento de uma "arquitetura de participação", ou seja, sistemas computacionais que incorporam recursos de interconexão e compartilhamento de tecnologias e de saberes.

GHISLENI et. al (2019) sustentam que a interação que caracteriza a Web 2.0 é inclusiva, já que "cada vez mais as pessoas preferem participar de uma nova geração de comunidades produzidas por usuários nas quais eles mesmos interagem e criam juntamente com seus colaboradores."

Para GHISLENI et. al (2019), a convergência digital trouxe ao campo educação, especialmente no que tange às ferramentas $E A D$, a transmutação de uma "sociedade com sistema educativo" para uma "sociedade da educação". De acordo com os autores, a convergência digital traz um saldo positivo para os profissionais da educação:

(...) o interessante é que o número de aplicativos disponíveis para profissionais da educação e alunos aumenta a cada dia. Alguns são mais fáceis de encontrar e de utilizar, outros já demandam mais tempo e prática para que o bom uso possa acontecer, mas todos podem agregar, com maior ou menor ênfase, oportunidades interessantes para motivar o ensino e a aprendizagem.

Resta evidenciado, portanto, que a convergência digital impacta diretamente não apenas o desenvolvimento de Ambientes Virtuais de Aprendizagem compatíveis com esses recursos tecnológicos, mas também as práticas pedagógicas como um todo - inclusive no âmbito da educação híbrida ou presencial. Isso porque as plataformas e recursos disponíveis permitem que o aluno vivencie novas dimensões da experiência educacional, assumindo um papel de protagonista e coautor da informação que permeia o aprendizado próprio e dos colegas.

\section{CONSIDERAÇÕES FINAIS}

Da análise do material bibliográfico pesquisado, depreende-se que a Web 2.0 e a convergência digital que a caracteriza impactam diretamente o modo como se realizam as práticas pedagógicas nos ambientes digitais de aprendizagem, já que: 
- Favorece o protagonismo educacional do estudante;

- Estimula a curiosidade do aluno;

- Possibilita a interatividade, eis que o aluno pode figurar como difusor, e não apenas receptor de informação;

- Aproxima a escola e a comunidade, já que a informação produzida nas plataformas EAD podem ser difundidas de modo dinâmico junto à sociedade.

A convergência digital afeta consideravelmente, de modo positivo, o modo de desenvolvimento dos Ambientes virtuais de Aprendizagem, já que seus recursos tornam possível o que os críticos da pedagogia tradicional tanto almejável: o protagonismo do estudante, já que o conhecimento revela-se como uma construção coletiva, colaborativa..

Além disso, a mobilidade proporcionada pela Web 2.0 permite que os processos de ensino e aprendizagem não fiquem adstritos ao espaço físico da sala de aula, já que as interações entre professores e alunos podem ocorrer por meio de qualquer dispositivo com acesso à internet que revele-se compatível com o ambiente virtual de aprendizagem escolhido.

A ubiquidade que caracteriza a Web 2.0 possibilita tanto a comunicação síncrona quanto a comunicação assíncrona entre professores e alunos, de modo que o fator tempo deixa de afigurar-se como um limitador das relações educacionais.

O aluno EAD contemporâneo, graças às plataformas que agregam os recursos de convergência digital típicos da Web 2.0, não está apenas acessando informações: ele as compartilha, comenta, modifica, interage, enfim, é ao mesmo tempo o receptor e o difusor de informações.

Os Ambientes Virtuais de Aprendizagem compatíveis com os recursos de convergência digital viabilizam a construção social da informação, fenômeno que gera novas expectativas do público dos cursos EAD, mas não ficam adstritos a esse público, já que é cada vez mais frequente a incorporação desses recursos a práticas pedagógicas no ensino híbrido e, até mesmo, no ensino presencial.

Cabe à escola, aos professores e à equipe pedagógica, ao adotar ou desenvolver Ambientes virtuais de Aprendizagem, alinhar o planejamento estratégico de cursos às dimensões proporcionadas pelos recursos da Web 2.0. Desse modo, tanto os professores quanto os alunos conseguirão aproveitar ao máximo os benefícios trazidos pelas ferramentas de convergência digital, aprimorando e tornando mais aprazível a jornada de ensino e aprendizado. 


\section{REFERÊNCIAS}

ALVES, Elder P. Maia. A digitalização do simbólico e o capitalismo culturaldigital: a expansão dos serviços culturais-digitais no Brasil. Soc. estado., Brasília , v. 34, n. 1, p. 129-157, Jan. 2019 . Disponível em: <http://www.scielo.br/scielo.php?script=sci_arttext\&pid=S0102-

69922019000100129\&lng=en\&nrm=iso>. Acesso em: 06 Set. 2019.

ANDRADE, Hurika Fernandes de. Efetividade do uso de ferramentas da web 2.0 em AVAs: colaboração, autonomia e autoria do aluno. Disponível em: $<$ https://repositorio.ufpe.br/bitstream/123456789/13234/1/Disserta\%c3\%a7ao\% 20Hurika\%20Fernandes\%20de\%20Andrade.pdt>. Acesso em: 02 Mar. 2019.

ASSIS, Simone Gonçalves; AVANCI, Joviana Quintes. A visão que os adolescentes têm de si: imagens nos espelhos. Disponível em: $<$ http://books.scielo.org/id/vdywc/pdf/assis-9788575413333-04.pdfts. Acesso em: 01 Jun. 2019.

BRUCH, Kelly Lissandra; GOULART, Guilherme Damásio. Tecnologias da informação e comunicação, o ensino do Direito e o papel do professor. Disponível em: <http://coral.ufsm.br/congressodireito/anais/2015/7-3.pdts. Acesso em 18 Mar. 2019.

BUGARELLI, Sérgio. Tecnologia digital e educação: o uso de novos suportes midiáticos no ensino jurídico. São Paulo: Universidade Presbiteriana Mackenzie, 2011, 150 p.

FARIA, Adriana Ancona de.Reflexões sobre a educação jurídica: desafios ao ensino e à pesquisa. Disponível em: $<$ https://dialnet.unirioja.es/descarga/articulo/5126572.pdf>. Acesso em 01 Mar. 2019.

FARIA, Adriano Antonio; SALVADORI, Angela. A educação a distância e seu movimetno histórico no Brasil. Disponível em: $<$ http://santacruz.br/v4/download/revista-academica/14/08-educacao-adistancia-e-seu-movimento-historico-no-brasil.pdts. Acesso em: 01 Set. 2019.

GHISLENI, Taís Steffenello; BARRETO, Henrique da Costa; PREREIRA, Angélica Moreira. Plataformas vinculadas à educação: um mapeamento de possibilidades.

Disponível

em: 
<http://www.periodicos.ufes.br/kirikere/article/view/21594>. Acesso em 02 Set. 2019.

SOLOMON, Gwen; SCHURM, Lynne. Web 2.0: New tools, new schools. Disponível em: <http://www.iste.org/docs/excerpts/NEWTOO-excerpt.pdf $>$. Acesso em: 13/06/2019.

SANTAROSA, Lucila Maria Costi; CONFORTO, Débora; BASSO, Lourenço de Oliveira. Ferramentas de autoria e de colaboração: discutindo a acessibilidade e a usabilidade na perspectiva da Web 2.0. Brazilian Symposium on Computers in Education (Simpósio Brasileiro de Informática na Educação - SBIE), [S.I.], out. 2012. ISSN 2316-6533. Disponível em: <https://brie.org/pub/index.php/sbie/article/view/1621>. Acesso em: 02 set. 2019.

SANTOS, Álisson de Almeida. A utilização de ambientes virtuais de aprendizagem na educação presencial: o caso do ensino jurídico na Universidade Federal de Juiz de Fora. Disponível em: <http://livrozilla.com/doc/270352/a-utiliza\%C3\%A7\%C3\%A3o-de-ambientesvirtuais-de-aprendizagem-na-edu...>. Acesso em: 02 Set. 2019; 


\title{
MÍDIAS NA EDUCAÇÃO SEXUAL: DOS SABERES AOS HORIZONTES DA PRÁTICA PEDAGÓGICA NA PERSPECTIVA DO CURSO DE EXTENSÃO EM FRANCA-SP
}

\author{
FERNANDES, Ítalo \\ CRUZ, Pâmela Cian da \\ NASCIMENTO, Thaís Rodrigues de Carvalho
}

\section{INTRODUÇÃO}

\subsection{Breve histórico da Educação Sexual no Brasil}

A sexualidade esteve presente desde os primórdios, vista por várias nuances ao decorrer do tempo, da qual em cada época apresenta suas peculiaridades.

Durante muito tempo, pouco se falava sobre sexo e sexualidade, existe ainda quem não saiba diferenciar esses termos, do qual sexo, a grosso modo, está relacionado ao ato sexual, e sexualidade é para além do sexo, o que nos envolve ao sexo, incluindo os afetos, o modo de se relacionar com as pessoas, a imagem corporal, carinho, toque, a comunicação (verbal e não verbal), gênero, identidade de gênero, identidade sexual, orientação sexual, normas e valores culturais, ou seja, a sexualidade está em tudo, pensando no indivíduo crítico como autor da própria história e dono do seu próprio corpo. (Figueiró 2017)

O sexo sempre foi, e ainda é no Brasil, visto de maneira velada, dotada de tabus e preconceitos. Disciplinar o corpo era uma palavra-chave usada como dispositivo de poder, como salienta Foucault (1987).

Bueno e Ribeiro (2018) apontam para pesquisas sobre a Educação Sexual no Brasil significativas que contribuem para a compreensão de sua trajetória, onde alguns autores destacados são Chauí (1984), Rosemberg (1985), Pinheiro (1997), Figueiró (1998), Ribeiro (2004), Silva (2002) e Bedin (2016). Essas investigações permitem-nos refletir sobre a educação ao encontro da sexualidade em diferentes períodos da história.

Ribeiro (2004, p.16), retrata o Brasil Colônia pelo "sexo pluriético libidinoso", este voltado para o homem, ao qual era submisso a sua mulher. Os homens uniam-se com a índias, e com elas tinham vários filhos. Isso não afetava em nada como era visto o homem, já que eram incentivados a manterem relações sexuais como modo de provar a sua masculinidade. 
Nesse período até mesmo os padres encontravam-se com as índias. O concubinato também era uma prática recorrente da época. A mulher era sempre tida no papel de submissa, humilde e acrítica, casando-se muito jovem com homens mais velhos.

Já no século XIX, com as mudanças ocorridas em sociedade, o início da urbanização tem-se a concepção de uma sexualidade higienista. Preocupados com a saúde, o discurso religioso passa a ser médico, uma vez que os perigos de contrair doenças são vistos como prioridade. O não ao sexo livre passa de pecado a atenção à saúde. (Ribeiro apud Costa 1989). Nesse sentido, foram publicadas várias obras pelos médicos, sacerdotes e professores relacionadas à sexualidade e saúde, passando então a oferecer orientação as famílias e a educação, a valorizar a criança e os costumes sanitários dessa família, uma vez que sua higiene era precária, considerando ser pilares importantes a desenvolver em sociedade. Nesse período tem-se a criação do termo sexologia, onde fica a cargo dos médicos os saberes produzidos e orientação a prática sexual de cada um.

Com esse avanço, alguns colégios iniciaram seus projetos com aulas de Educação Sexual, considerando o biológico e depois partindo para o psíquico-social. Mesmo em andamento, os projetos foram cortados devido a represália em que sofreram pela ditadura em 1964. Alunos suspensos, professores e diretores exonerados foi o que restou da tentativa de implantação da sexualidade na escola.

A censura desde então foi muito grande, o que gerou grande retrocesso na área da sexualidade, impedindo assim sua implementação em espaços escolares. Após essa ruptura, "a partir de 1978, com a abertura política do presidente Ernesto Geisel, é que oficialmente se retoma a implantação de projetos de orientação sexual nas escolas. " (Ribeiro 2004, pág. 21)

Dessarte, mesmo com vários retrocessos ocorridos nesse período, no que tange a Educação Sexual, novamente ela veio se destacando, e após os anos de 1978 ganhou também o apoio das secretárias e órgãos públicos assumem os projetos nas escolas. Ainda em tempo, esses eram tratados como orientação sexual, como está disposto nos Parâmetros Curriculares Nacionais. (Brasil 2001). Desse momento em diante, os projetos desenvolvidos pela escola deslancharam, de modo a ser encarada como necessária e importante, tanto que foi incluída nos Parâmetros Curriculares Nacionais, no ano de 1996, com o amparo da Lei de Diretrizes e Bases da Educação.

Com o amparo da LDB, os currículos e projetos em ação, os PCNs, a Declaração dos Direitos Humanos, dentre outros documentos importantes, pensou-se que a Educação Sexual estivesse caminhando para 
avançar, já que os saberes historicamente construídos sobre a temática evidenciaram a importância em desenvolver o sujeito em sua plenitude, inclusive englobando a sua sexualidade, visando os reflexos para a construção do sujeito, porém, nos dias de hoje, onde a moral cívica predomina, a sexualidade perde espaço, sendo atacada por falácias e inverdades que acabam por denegri-la e prejudicar o andamento da mesma, uma vez que perde-se o apoio dos governantes, e não é considerada necessária - por muitos - como contribuição no desenvolvimento pleno da pessoa.

\subsection{Mudanças na Educação: novas tecnologias}

Sabe-se que ao passar dos anos as sociedades têm se desenvolvido e se transformado. Essas transformações ocorreram em todos os setores sociais, inclusive o da educação. Os modos de se ensinar variaram muito, desde a educação apenas para burgueses até a educação para todos, o que foi um grande marco histórico, dentre outras contribuições. Desde então, várias mudanças circundam o meio acadêmico, sendo desde a infância até a idade adulta.

Atualmente diversas modalidades de ensino desde os cursos técnicos, de extensão, até pós-graduação, doutorado entre outros níveis de ensino são apresentados com certa facilidade de acesso, em detrimento dos avanços e transformações sócias, mas também pela facilidade que trouxeram os avanços tecnológicos.

A intensificação desses acabam por fortalecer vínculos, já que os meios de comunicação em consonância com os recursos midiáticos interferem diretamente na vida do indivíduo, considerando-a como transmissora de conhecimento e contribuinte para a formação da autônoma do ser humano, levando-o para todos os espaços.

O meio acadêmico não fica atrás, já que este é passível de ferramentas que corroboram a facilitar o ensino por meio da ludicidade já que os recursos midiáticos, além de proporcionar maior interesse e facilidade na compreensão de alguns conceitos, levam conhecimento, voz, liberdade e autonomia, por todos os cantos.

Todavia, é preciso estar atento ao que o avanço tecnológico oferece em suas entrelinhas, como salienta Caldas (2005), uma vez que reduziu a capacidade de leitura para além dos códigos linguísticos. Esse fato traz inúmeros problemas, uma vez que a interpretação de texto fica à mercê da superficialidade, sugerindo uma linguagem vazia.

Ainda assim, no que diz respeito a educação audiovisual no âmbito escolar é necessário compreender que ainda 
parece que a escola está em constante desatualização, que é sublinhada pela separação entre a cultura e a educação. A cultura localizada num saber-fazer e a escola num saber-usar, e nesse saber-usar restrito desqualifica-se o educador, que vai ser sempre um instrumentista desatualizado. Essa é uma das razões da separação entre educação e cultura. Outra, talvez a mais importante, é que, atualmente, há uma grande maioria de pessoas cuja inteligência foi e está sendo educada por imagens e sons, pela quantidade e qualidade de cinema e televisão a que assistem e não mais pelo texto escrito (ALMEIDA, 2004, p. 8).

Desse modo, não há intencionalidade educacional que funcione através dos recursos midiáticos sem a devida reflexão através das imagens, sons e toda gama de infinitas possibilidades tecnológicas, uma vez que, o professor como mediador deve fazer aproximar a reflexão do que constantemente tem sido revelado nas mídias, buscando a qualidade máxima da ferramenta, porém, este profissional precisa estar em constante atualização e em formação para que possa apropriar-se sempre de novos conceitos emergidos ou não no espaço escolar.

Esse pensar reflete diretamente na ação a que se almejou para este estudo, uma vez que, ao fazê-lo, buscou utilizar os recursos midiáticos culturais no curso de extensão que proporcionassem diálogos a que fizessem os participantes refletir sobre tais indagações e sobre o que estava sendo disposto, não como mero ouvintes massificados, mas sim com atenção e criticidade, a fim de que pudessem reelaborar conceitos.

A vista disso, a sexualidade presente em todos os lugares, assim como a tecnologia, precisa ser trabalhada, refletida e reiterada como inerente ao ser humano, mas com olhares que precisam estar em constante renovação e atenção, a fim de oportunizar momentos que priorizem o ser reflexivo para além do que se encontra em exibição.

\section{METODOLOGIA}

Esse artigo trata-se de uma pesquisa empírica que utilizou de uma amostragem não probabilística para a coleta dos dados. Posteriormente, foram analisados na abordagem qualitativa.

A princípio foi realizado um levantamento bibliográfico que proporcionou o início da discussão, levando a refletir como os profissionais que lidam diretamente com o processo educativo aplicam a abordagem para uma Educação Sexual? Em seguida, ancorados nesse fenômeno contemporâneo, levantamos a possibilidade de realizarmos a oferta de um curso de extensão que ocorreria na Universidade de Franca, na modalidade presencial e gratuita para discentes da universidade e comunidade em geral. 
Após contatos com a instituição e aprovação da oferta do curso, foi realizada a divulgação do folder que continha todas as informações sobre 0 encontro. $\mathrm{Na}$ data em questão, os autores estiveram presentes para a formação e coleta dos dados para a escrita desse artigo que contemplou os conhecimentos prévios dos participantes sobre o que pensavam acerca da Educação Sexual. Assim como noutro momento, em que os alunos tiveram que descrever os papéis sociais de gêneros, através de uma folha de sulfite dividida ao meio.

Em uma das partes descreveriam o que são coisas de meninos e na outra aba o que são coisas de meninas. Essas representações foram utilizadas para análise logo abaixo.

\section{O CURSO DE EXTENSÃO}

\subsection{Primeiro momento}

Foram disponibilizadas 30 (trinta) vagas para os estudantes e comunidade externa. No primeiro momento, os pesquisadores tiveram acesso a lista dos inscritos para o curso, da qual continha 22 (vinte e dois) participantes inscritos. No entanto, apareceram para o encontro apenas 3 (três) alunas.

Essa dificuldade foi avaliada da seguinte forma: os alunos se inscrevem nos cursos de extensão universitária esperando apenas o certificado para contabilizar nas horas complementares dos cursos de graduação, não sabendo ou não se atentando que existe uma lista de presença na qual disponibiliza certificado apenas para os presentes.

O encontro se iniciou pela apresentação dos pesquisadores, em seguida as participantes se apresentaram falando do curso e período da graduação, quais os motivos que as levaram selecionar o curso de extensão universitária, bem como aspectos pessoais profissionais.

A participante 1 (um) é graduanda do curso de história e trabalha com organização de eventos. A participante 2 (dois) é graduanda em gastronomia e trabalha em um restaurante. A participante 3 (três) é graduanda em psicologia e trabalha no comércio.

O curso foi denominado: "Recursos midiáticos e pedagógicos para uma prática em Educação Sexual", com objetivo de refletir a prática de ensino em Educação Sexual na interface com as matrizes de sentidos escola, família, ciência, religião, política e mídia. Além disso, foram compartilhados materiais midiáticos e ferramentas pedagógicas que possibilitassem a formação continuada de educadores e psicólogos para essa atuação. 
O encontro foi dividido em 2 (dois) momentos: 1) (Des) construindo conceitos, cujo objetivo foi discutir as diferenças entre sexo, sexualidade e Educação Sexual; contributos da Educação Sexual; Educação Sexual na escola; e Legalidade de uma Educação Sexual. 2) Mídias para Educação Sexual, os pesquisadores apresentaram trailers de filmes, trechos de telenovelas, séries, músicas, vídeos educativos, dinâmicas, livros, revistas, sites, dentre outros.

Para dialogar com as diferenças entre sexo, sexualidade e Educação Sexual, os pesquisadores usaram o quadro para escrever as concepções de cada participante em cada conceito, depois foi explicado com base na teoria as diferenças entre eles.

Entende-se por sexo o fato natural, hereditário, biológico, diferença anatômica de macho e fêmea, fisiologia, genética, sistema reprodutor e hormonal. Sexo se refere a atração física e relação sexual (BONFIM, 2012).

Poderíamos dizer que a escola nos dias de hoje, fala de "sexo" e não de "sexualidade", uma vez que a Educação Sexual da escola ainda é pautada na concepção médico-higienista do século XIX, no combate à masturbação e contagio de doenças sexualmente transmissíveis, sem resgatar as concepções histórico-culturais, sem buscar refletir sobre os valores e transformações ocorridas na sociedade. Existem grandes diferenças entre informar e formar, educar e conscientizar (BONFIM, 2012).

A sexualidade é inerente ao sujeito, é uma dimensão humana que vai além do paradigma biológico, está ligada a questões históricas, políticas, sociais e culturais é um conceito amplo, envolvendo impulso sexual, desejo, busca de um objeto sexual, influência da cultura, da sociedade, da família, da moral, dos valores, da religião, da sublimação e da repressão. (FIGUEIRÓ, 2006; REPOLHO, 2013).

Nos dizeres de Chauí (1984) podemos definir:

A sexualidade não se confunde com um instinto, nem com um objeto
(parceiro), nem com um objetivo (união dos órgãos genitais no coito).
Ela é polimorfa, polivalente, ultrapassa a necessidade fisiológica e
tem a ver com a simbolização do desejo. Não se reduz aos órgãos
genitais (ainda que estes possam ser privilegiados na sexualidade
adulta) porque qualquer região do corpo é susceptível de prazer
sexual, desde que tenha sido investida de erotismo na vida alguém, e
porque a satisfação sexual pode ser alcançada sem a união genital.
(p. 15)

Bonfim (2012) revela a sexualidade é um "conjunto de afetos, cuidados, envolvendo sexo, papéis sexuais, orientação sexual, erotismo, prazer, envolvimento emocional, amor e reprodução. " (p. 28). Desde o nascimento a sexualidade começa a ser desenvolvida e está vinculada ao 
crescimento e a forma como da criança se relaciona nas relações intrafamiliares e nas relações extrafamiliares, como a escola e igreja.

A Educação Sexual busca orientar, ensinar, informar, refletir, discutir sobre aspectos da sexualidade. A educação sexual vislumbra a vivência gratificante e responsável da capacidade humana de desejar e ser desejado, amar e ser amado. (BONFIM, 2012)

A finalidade da Educação Sexual é contribuir para o educando experienciar sua sexualidade de forma saudável e feliz, desenvolvendo valores e atitudes positivas. Esse processo vai além de auxiliar nas Infecções Sexualmente Transmissíveis (IST) ou da gravidez precoce, a Educação sexual busca o desenvolvimento integral da personalidade do sujeito, e consequentemente sua qualidade de vida (FIGUEIRÓ, 2006). Os jovens aprendem comportamentos sexuais responsáveis, auxilia na discussão de assuntos referentes a masturbação, iniciação sexual, homossexualidade, disfunções sexuais, violência sexual, assédio, feminicídio, prostituição, pornografia, dentre outros.

E por que a Educação Sexual na escola? A escola é o espaço para propagar o saber e educar sobre diversos aspectos do sujeito. É um campo fértil e ideal para dar orientação sexual, uma vez que é o ambiente onde crianças e adolescentes manifestam suas dúvidas e descobrem o potencial do seu corpo (REPOLHO, 2013).

No entanto, nota-se que a escola anula a potencialidade do corpo do educando, ainda se encontra no modelo de uma educação bancária, como estudado por Paulo Freire, como se corpo e mente estivessem separados, na díade mente-corpo, de nada interessa o corpo se é preciso apenas desenvolver aspectos intelectuais e cognitivos nesse aluno. Guacira Lopes Louro em "O corpo educado" (2000), nos diz que a ação pedagógica se destina em constituir o corpo "civilizado", formar homens e mulheres "de verdade", buscando verificar o quanto se aproxima ou afasta da norma desejada. A escola é uma instituição na qual marca o sujeito e constrói sua identidade social, identidade de gênero e sexual.

A sexualidade sempre é adiada para mais tarde, para depois da escola, apenas um assunto da vida adulta, já que é necessário manter a "pureza" das crianças e dos adolescentes, mesmo que para isso seja praticado a Educação Sexual do silêncio, da negação e da repressão das curiosidades e fantasias infantis e juvenis sobre as práticas afetivo/sexuais. As dúvidas e experimentação do prazer são remetidas ao privado por intermédio de estratégias de disciplinamento, desenvolvendo a culpa, a censura e estratégias de controle, acreditando que a sexualidade é assunto para se tratar em segredo, deixando de perceber a dimensão política e social que envolve esta questão. Quando aqueles ou aquelas que apresentam interesses distintos da 
norma heterossexual, o jeito é ser silenciado e segregado e nesse contexto se instaura a homofobia/transfobia (LOURO, 2000).

A autora aponta que a escola não detém o poder e responsabilidade de explicar as identidades sociais ou determiná-las. É preciso reconhecer que o silêncio, a imposição, a repressão e a proibição constituem partes significativas nas histórias pessoais de cada sujeito.

A todo instante, a sociedade de um modo geral é acometida por padrões e normas na qual se deve seguir para ser aceito. Essas imposições acompanham o sujeito em toda sua história de vida, é notável nas crianças e adolescentes a preocupação com o próprio corpo e o desejo de alcançar o ideal. A escola é o espaço onde as comparações e competições surgem, daí a importância de orientar/discutir com os educandos esses padrões que aprisionam tanto as crianças, jovens e adultos.

Santos, Momesso e Ribeiro (2014, p. 49) revelam que o corpo é o "sucesso ou o fracasso de alguém, sendo mensurado e formatado a todo instante em padrões e referenciais unívocos que devem ser almejados e desejados por todos. A medicina, a moda e o mercado se apossam do corpo e o constroem como produto". Essa concepção é descrita por Foucault (1984) como: o sujeito é guiado pelos dispositivos de poder com intenção de controlar o uso dos prazeres, a expressão da sexualidade, a ditadura do corpo perfeito.

Louro (2000) nos diz que o investimento no corpo é uma imposição cultural, deve-se adequá-lo aos critérios estéticos, higiênicos, morais relativos ao grupo social a que se pertence. A prescrição de saúde, vigor, vitalidade, juventude, beleza, força, são atribuídas ao corpo de homens e mulheres e são variadas de uma cultura para outra.

Desse modo, é necessário compreender que a Educação Sexual acontece de modo intencional ou não intencional, ou seja, a Educação Sexual seja ela recebida da família, escola ou de outras instâncias, são divididas em duas classificações: formal e informal. Figueiró (2006), mostra que a Educação Sexual formal é aquela deliberada, institucionalizada feita intencionalmente pela escola ou fora dela, já a Educação Sexual informal é aquela não intencional, um processo global de uma ação sobre o sujeito em seu cotidiano, desde o seu nascimento agindo direta ou indiretamente na vida afetiva/sexual. A Educação Sexual informal é a mais recorrente, uma vez que a sexualidade ainda é rechaçada por tabus, mitos, estigmas e preconceitos envolta de uma moral repressiva que ainda sofre influência do patriarcalismo.

Figueiró (2006) revela as quatro abordagens de uma Educação Sexual, são elas: religiosa, médica, pedagógica e emancipatória. A abordagem religiosa é a concepção mais tradicional, onde sexo é vinculado a procriação, ao amor, ao casamento. A abordagem médica se baseia na díade saúde- 
doença, o foco é o tratamento dos desajustes sexuais. A abordagem pedagógica é o processo ensino-aprendizagem dos conteúdos básicos/biológicos da sexualidade. A abordagem emancipatória, busca uma Educação Sexual como uma transformação social, na qual visa as discussões de questões que envolvem as relações, aceitação das diferenças e respeito a diversidade. A sexualidade é tratada com uma visão positiva com o enfoque histórico, social, político e cultural.

Nota-se que no universo escolar existe uma dificuldade em aceitar as diversidades que compõe o corpo discente. E, portanto, a inserção da Educação Sexual em uma abordagem mais emancipatória na escola, enfrenta grandes desafios, dentre eles estão: a falta de formação continuada de toda comunidade escolar; (BRUNS: MELO, 2016) a dificuldade de desmistificar a postura dos pais frente a sexualidade de seus filhos/as; e dificuldade de desconstruir permanentemente os preconceitos e estereótipos sobre a sexualidade humana.

\subsection{Segundo momento}

A segunda parte do curso de extensão se destinou a apresentação de mídias para uma Educação Sexual, foi exibido o trailer do filme " Eu não sou um homem fácil”, disponível na Netflix, um site privado que permite ter acesso a filmes e séries; um trecho da telenovela "Chocolate com pimenta" exibida pela rede de televisão Globo em 2003/2004; a música "Todxs putxs" da cantora Ekena visando questionar as imposições e padrões de beleza impostas pela sociedade e mídia; exibição do canal da pesquisadora Mary Neide Figueiró do canal "Educação Sexual para SER feliz!. Foi mencionado outros tantos recursos midiáticos e pedagógicos que podem ser utilizados para uma Educação Sexual.

Para exemplificar e coletar a percepção das participantes após as explicações dos conceitos optou-se em pedir que elas escrevessem em uma folha "coisas de menino" e "coisas de menina" e nestas colunas escrevessem seus pensamentos ou aquilo que é imposto pela sociedade como sendo de menino ou menina.

Essa dinâmica tinha por objetivo discutir questões de gênero, desmistificar as imposições e diferenciações apregoadas na família, na escola, na igreja, dentre outros contextos na qual o sujeito está inserido.

As alunas escreveram na coluna "coisas de menina": boneca, brinquedos que imitam utensílios domésticos, comportamentos delicados, ser frágil, ter uma voz passiva, usar rosa, jogar vôlei, usar vestidos e salto alto, ser sensível, ser mãe, cuidar da casa e de todos os serviços domésticos, cuidar 
dos filhos, estar disponível para o marido. Na coluna "coisas de menino": bola, carros, bicicleta, esportes radicais, ser forte, ter voz ativa, usar azul, usar calça e tênis, não chorar, trabalhar e prover sustento, brincar com os filhos, ser sexualmente ativo, skate, bola, jogar futebol, carrinho de rolimã, soltar pipa, roupas masculinas, ajudar a mãe arrumar a casa, lavar roupas.

Foi observado ao longo do curso que uma participante apresentou mais resistência e pensamentos na dicotomia homem-mulher, fazia comentários, como por exemplo, jogar futebol era mais comum aos homens, falava sobre seu filho com um amigo gay, compactuando alguns comentários preconceituosos e ainda enraizados na concepção heteronormativa.

Essa dicotomia homem-mulher, a divisão em corpos femininos e masculinos, prevalece na sociedade de modo geral e principalmente na escola prevalece um discurso normativo e prescritivo, corroborando para legitimar algumas identidades e práticas sexuais e marginalizar outras pelo silenciamento (RIBEIRO; PRADO, 2013).

As questões de gênero ainda permeiam a vida cotidiana e é visto como natural a divisão entre "coisas de menino" e "coisas de menina", existe uma grande resistência em considerar a Educação Sexual como parte global do sujeito. (RIBEIRO; PRADO, 2013). Todas as práticas e linguagens que cercam o cotidiano escolar são produtoras de marcas que são a todo o momento investido pelas diversas instâncias sociais, reiterando identidades e práticas hegemônicas. (LOURO, 2000).

Essa distinção entre o que seria corpos femininos e masculinos, prevalece em um discurso normativo e prescritivo de como se apresentam e como são classificadas as características físicas, as vestimentas, a comunicação, os valores e interesses de cada gênero. Essa dicotomia é determinada pela sociedade e sempre, construída historicamente e culturalmente (BONFIM, 2012).

Estudar gênero possibilita romper paradigmas e concepções construídas e enraizadas uma vida toda. A visão de que sexo e gênero são voltadas para genitálias e portanto, ser homem significava ter pênis e ser mulher significava ter vulva, isso mostrou-se ultrapassado e sem explicações suficientes para grandes autoras como Simone de Beauvoir (1949), Judith Butler (2015), entre outras/os, que começaram a questionar em quais estruturas essas concepções estavam embasadas.

A partir das primeiras postulações sobre gênero, através de Simone de Beauvoir com a ideia "não se nasce mulher, torna-se mulher" alguns avanços apareceram nesse contexto, como sexo uma construção social (BEAUVOIR, 1949). Sexo e gênero para Butler se qualifica por igual, ser mulher é fictício e isso rompe com a estrutura binária do gênero, considera 
gênero como "não natural", assim não há relação entre corpo de alguém e seu gênero. O sujeito -em - processo construído no discurso é o ator da sua própria identidade dentro de um palco metafórico e performativo de suas próprias escolhas. O sujeito escolhe dentro das opções que the são oferecidas no contexto que está inserido (SALIH, 2015). Esse conceito de performatividade contribui para os estudos sobre transexuais e travestis como um grupo que desalinha a sociedade, subvertendo uma ordem estabelecida.

Desse modo, é necessário romper barreiras para descontruir a lógica binária dos gêneros que define posicionamentos diferentes para cada gênero, ou seja, a mulher como um corpo frágil e submisso e o homem como viril e dominador.

\section{HORIZONTES}

No Ethos Contemporâneo pode-se dizer que houve alguns avanços, dentre eles a independência da mulher, empoderadas e com espaços em lugares antes barrados como a política e o mercado de trabalho. Muito embora, na modernidade a ditadura do corpo perfeito e os padrões estabelecidos pela mídia e pela própria sociedade, escravizam homens e mulheres que buscam um corpo sarado. O homem machão cede lugar ao cuidado de si e do corpo com atitudes comportamentais mais leves e menos centradas nas questões sexuais. (FEITOSA; RAGO, 2008), possibilitando que pesquisadores e interessados busquem problematizar a sexualidade exposta na mídia e nos veículos de informação, como jornais, revistas, livros, etc.

As últimas décadas têm mostrado novas possibilidades de relações humanas, principalmente as relações de gênero, buscando o respeito e a liberdade para escolher de acordo com seus desejos pessoais. (FEITOSA; RAGO, 2008). Em contrapartida, os avanços tecnológicos produzem uma cultura imediatista que banaliza e vulgariza o sexo, com grande superficialidade dos vínculos afetivos.

Esse cenário atual emerge uma grande necessidade de buscar distribuir uma Educação Sexual emancipatória como um agente de transformação social que pode conduzir discussões que desvelem a sexualidade como um estudo que trate além do sexo, os sentimentos e valores, as atitudes e normas socioculturais construídas através da história. (FIGUEIRÓ, 2006).

Apropriar-se do conhecimento histórico da sexualidade e gênero facilita à compreensão de aspectos tão preconceituosos e críticos presentes na cultura tradicional, ainda prevalente no Brasil. A recusa de informação é um meio de manter o controle, estratégia do silêncio que dá lugar as palavras, 
dando-Ihe sentidos, valores, criando normas, interditos e permissões para o sujeito manifestar seus desejos afetivo/sexuais. (CHAUÍ, 1984).

Buscar compreender as questões de gênero e sexualidade permite que ao olhar as desigualdades na sociedade atual, questionem-se os papéis definidos entre homens e mulheres. A mulher sendo obrigada a casar e ter filhos para ser feliz, como um objeto sexual atrativo e usado nas redes televisivas, nas propagandas e revistas para render maiores lucros nos produtos. O homem dominador, aquele que sai de casa para prover o alimento e não tem obrigações domésticas. O homem infiel considerado como "garanhão" e a mulher infiel "puta". Esses discursos determinados para cada gênero, embora analisados e descontruídos cada vez mais na cultura atual, ainda é muito presente e disseminado mediante as instituições e figuras de poder que pregam o conservadorismo.

Desse modo, torna-se cada vez mais importante abordar a Educação Sexual criticamente, refletindo através de uma visão sociocultural a reconstrução e a reelaboração de conceitos que possam orientar o diálogo em sexualidade. Para isso, é necessário preocupar-se primeiro com os profissionais que serão os educadores sexuais.

\section{REFERÊNCIAS}

ALMEIDA, Milton José. Imagens e sons: a nova cultura oral. 3 ed., São Paulo: Cortez, 2004.

As diferenças entre sexo e sexualidade. In: educação sexual para ser feliz. "Mary Neide Figueiró". 2017. Disponível em: https://www.youtube.com/watch?v=11eUAGKciuo

BEAUVOIR, S. O segundo sexo. São Paulo: Círculo do Livro, 1949.

BONFIM, C. Desnudando a Educação Sexual. Campinas: Papirus, 2012.

BRASIL. Secretaria de Educação Fundamental. Parâmetros curriculares nacionais: pluralidade cultural, orientação sexual. 3 ed. - Brasília: MEC/SEF, 2001.

BRUNS, M.A.T.; MELO, S.M.M. Desafios da Educação Sexual: interfaces pertinentes com Comunicação e Tecnologia. Curitiba: Editora CRV, 2016.

CALDAS, Graça. Mídia, escola e leitura crítica do mundo. Disponível em: http://www.scielo.br/scielo.php?script=sci_arttext\&pid=S010173302006000100006 
CHAUÍ, M. Repressão Sexual: essa nossa (Des)conhecida. São Paulo: Brasiliense, 1984.

DORIGONI, Gilza Maria Leite; SILVA, João Carlos da. Mídia e Educação: o uso das novas tecnologias no espaço escolar. Disponível em: http://www.diaadiaeducacao.pr.gov.br/portals/pde/arquivos/1170-2.pdf

FEITOSA, L.M.G.C.;RAGO, M. Somos tão antigos quanto modernos? Sexualidade e gênero na Antiguidade e na Modernidade. In Rago, M. \& Funari, P.P.A. (Orgs.). Subjetividades Antigas e Modernas. São Paulo: Annablume, 2008.

FIGUEIRÓ, M. N. D. Formação de Educadores Sexuais: Adiar não é mais possível. Campinas: Mercado de Letras; Londrina, PR: Eduel, 2006.

FOUCAULT, M. História da Sexualidade II: O uso dos prazeres. Rio de Janeiro: editora Gallimard, 1984.

FOUCAULT, Michel. Vigiar e punir. Petrópolis: Vozes, 1987

LOURO, G.L. O corpo educado: pedagogias da sexualidade. Belo Horizonte: Autêntica editora, 2000.

REBOLHO, A. C. F. Se essa rua fosse minha: professores e gestores discutem a exploração sexual de menores nas escolas? Curitiba: CRV., 2013.

RIBEIRO, A.I.M.; PRADO, V.M. Falando sobre gênero e sexualidades na educação: vamos nos permitir? Curitiba: Editora CRV, 2013.

SALIH, S. Judith Butler e a Teoria Queer. Belo Horizonte: Autêntica editora, 2015.

SANTOS, F.; MOMESSO, M. R.; RIBEIRO, P. R. M. Gestos de subjetivação: as dificuldades para realizar uma história do corpo sexualidade. EXEDRA, 1, 47-63, 2014. Disponível em https://dialnet.unirioja.es/servlet/articulo?codigo=6499902 Acesso em: 15/02/2019.

Sexualidade e Educação: aproximações necessárias. Paulo Rennes Marçal Ribeiro (org.) - São Paulo: Arte \& Ciência, 2004. Disponível em: https://books.google.com.br/books?id=K2gni9_O$7 w C \& p g=P A 12 \& l p g=P A 12 \& d q=$ breve+historico+da+educa\%C3\%A7ao+sexual +no+brasil+paulo+rennes+ribeiro\&source=bl\&ots=AliEbyVtAb\&sig=ACfU3U34t AF6EsKAtZFOWp0XmUoh2SZ6BQ\&hl=pt-

BR\&sa $=X \& v e d=2 a h U K E w j 6 q Y z r 2 u v i A h W c H 7 k G H c B p D x A Q 6 A E w B n o E C A k Q A$

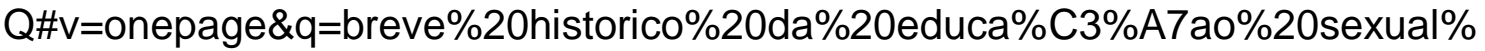
20no\%20brasil\%20paulo\%20rennes\%20ribeiro\&f=false 
ANEXOS

Anexo 1: Folder disponibilizado para inscrições no minicurso: Recursos midiáticos e pedagógicos para uma prática em Educação Sexual

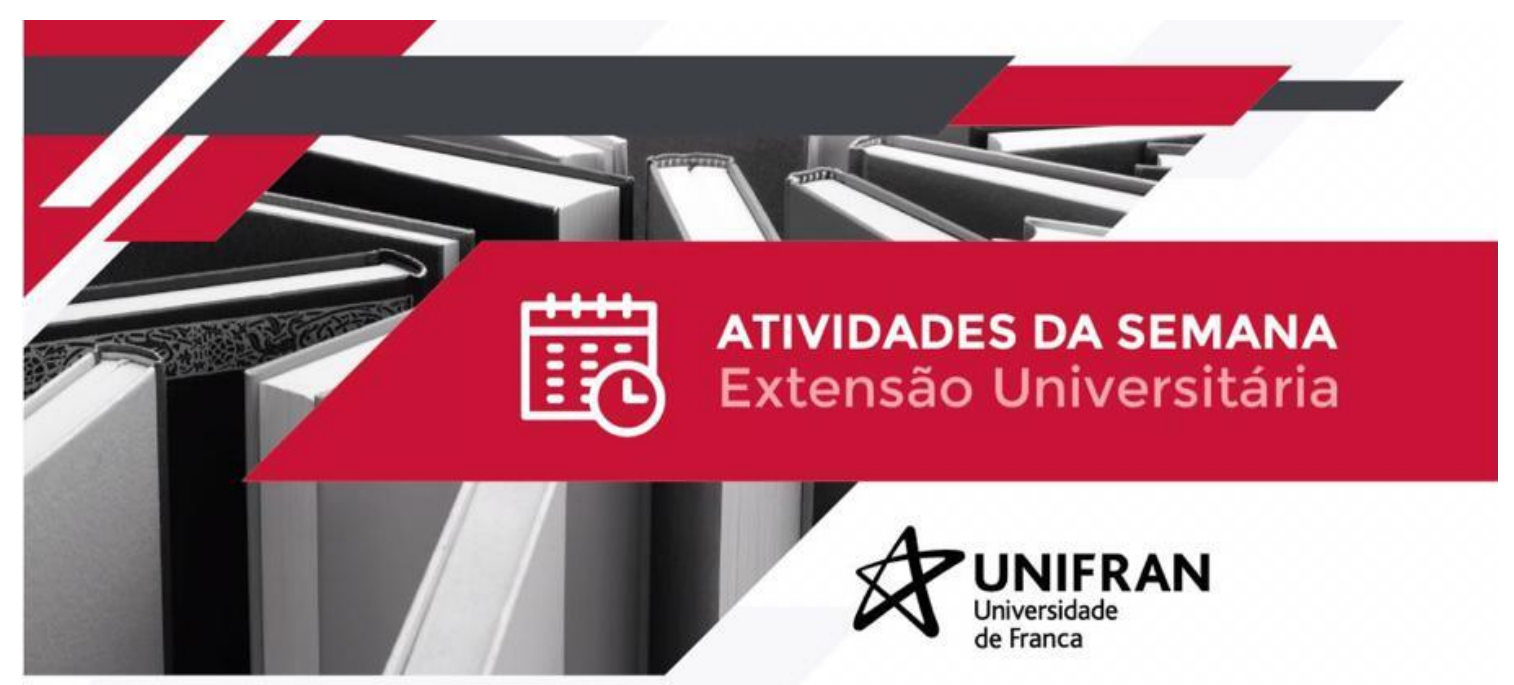

\section{Curso RECURSOS MIDIÁTICOS E PEDAGÓGICOS PARA UMA PRÁTICA EM EDUCAÇÃO SEXUAL}

Data: 25 de maio de 2019 (sábado)

Horário: $09 \mathrm{~h}$ às $12 \mathrm{~h}$

Local: Bloco bordô - sala 157

\section{Programação}

O encontro objetiva a reflexão da prática de ensino em Educação Sexual contextualizando com as matrizes de sentido escola-família na sociedade contemporânea. Compartilhamento de materiais midiáticos e criação de ferramentas pedagógicas que possibilitem a formação continuada de educadores e psicólogos para essa atuação.

\section{Responsáveis}

ÍTALO FERNANDES - Mestrando em Educação Sexual pela UNESP. Pós-graduado em Psicologia Organizacional e Graduado em Pedagogia pela Universidade de Franca. Membro do Grupo de Pesquisa SexualidadevidaUSP/CNPq, estuda "A vida afetivo-sexual e profissional de homens que vivem com HIV".

PÂMELA CIAN DA CRUZ BENGOZI - Mestrando em Educação Sexual pela UNESP - Araraquara/SP. Graduada em Pedagogia pela Universidade Estadual do Paraná - Unespar, campus Apucarana-PR. Atua como Professora da Educação Infantil na Rede Municipal de Ensino de Apucarana. Integrante do grupo de pesquisa GEFES - Formação de Educadores Sexuais.

THAÍS RODRIGUES DE CARVALHO NASCIMENTO - Mestrando em Educação Sexual pela UNESP. Psicóloga pelo Centro Universitário UNIFAFIBE, Bebedouro/SP. Atualmente trabalha como psicóloga clínica com ênfase na teoria psicanalítica. Membro do Grupo de Pesquisa Sexualidadevida-USP/CNPq, estuda "A familia e a Educação Sexual de filhos autistas".

\section{Público-Alvo}

Alunos e Comunidade em geral

\section{Investimento}

Evento Gratuito

\section{Informações}

(16) $3711-8828$

\section{Inscrições}

Portal do aluno ou http://www.unifran.edu.br/pos-graduacao-pesquisa-extensao/extensao/ 
Anexo 2: Escritos das participantes

$1-$

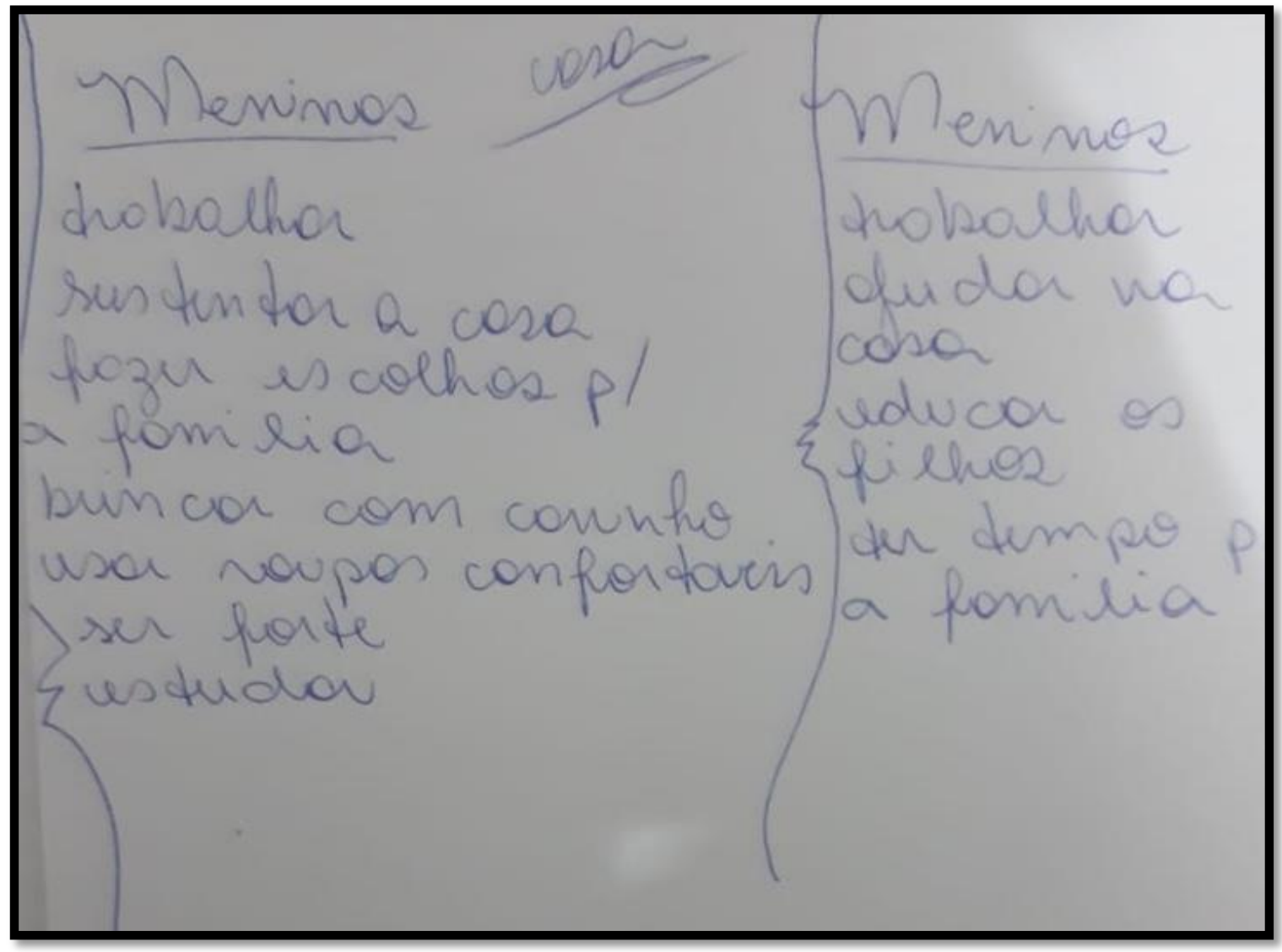

2 -

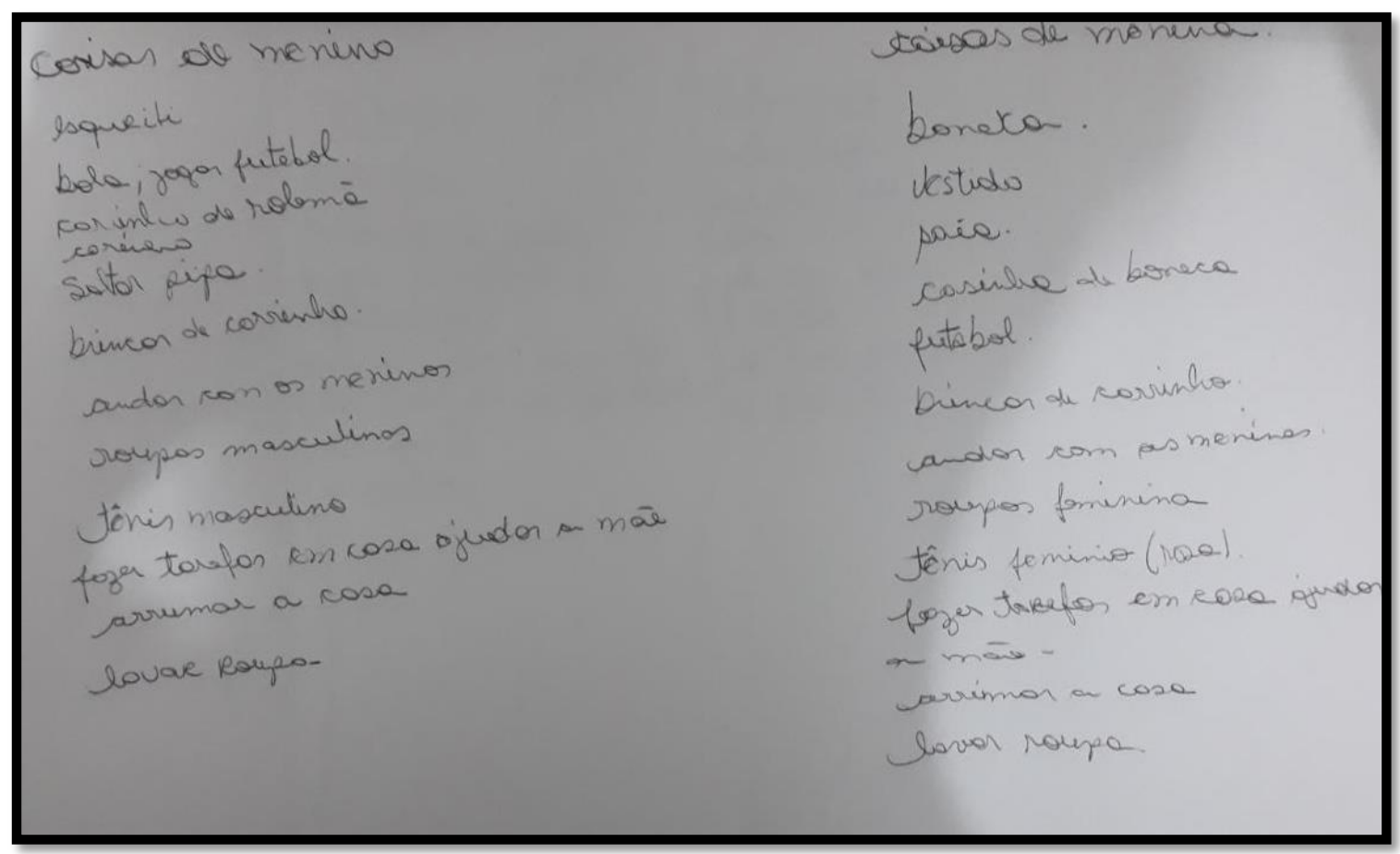

MÍDIAS NA EDUCAÇÃO SEXUAL: DOS SABERES AOS HORIZONTES DA PRÁTICA PEDAGÓGICA NA PERSPECTIVA DO CURSO DE EXTENSÃO EM FRANCA-SP — 


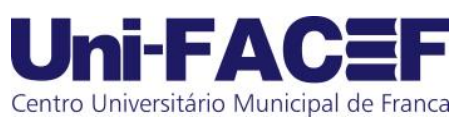

PRÁTICAS PEDAGÓGICAS EM DISCUSSÃO

ISBN: 978-85-5453-031-0

140

$3-$

Menina

Merimo

Bonecar

Bringuedos que

imitam utensilios

para widado dacara buciclete, esportes

$\checkmark$ Munina secomportar radicais

de forma "delicada" V Ser forte

$V$ ser frágul
serffter voz pássiva

Serfter voz ativa

FERNANDES, Ítalo; CRUZ, Pâmela Cian da; NASCIMENTO, Thaís Rodrigues de

Carvalho 


\title{
NOVOS OLHARES PARA AS PRÁTICAS PEDAGÓGICAS DIANTE DOS PROJETOS DE TRABALHO
}

\author{
GONÇALVES, Gustavo Henrique \\ Mestre em Saúde e Educação - UNAERP \\ gustavonatacao@yahoo.com.br \\ TAVARES, Graciele Faine \\ Especialista em Psicopedagogia - Centro Universitário Claretiano \\ gracielefaine@gmail.com \\ CLEMENTE, Guilherme Augusto Bertelli Fernandes \\ Doutorando em Ciências - UNIFRAN \\ engenheirocivilguilherme@yahoo.com.br
}

\section{INTRODUÇÃO}

A abordagem dos Projetos de Trabalho, delineada por Hernández (1998), desencadeou um intenso movimento em prol da transformação da prática pedagógica docente, em uma realidade que se contrapõe às práticas exclusivamente tradicionais, propondo uma (re)organização do processo de ensino, a promoção de situações de ensino-aprendizagem, a valorização e participação de todos os envolvidos no âmbito educativo.

Ao passo que, o trabalho docente pode ser impulsionado com base no ensino-aprendizagem baseado a partir da resolução de problemas e sob a ótica dos projetos. Neste contexto, o Projeto de Trabalho constitui-se proposta que pode surgir de uma questão imersa na vida social dos discentes e suas experiências, em uma relação que permita maior interação entre o grupo, pois conforme Hernández (1998), quando se trabalha a partir da perspectiva de projetos é possível considerar que a função da escola não é apenas ensinar conteúdos, nem vincular a instrução da aprendizagem. Revisar a organização do currículo por disciplina é a maneira de situá-lo no tempo e espaço escolares.

O que torna necessária a proposta de um currículo que não seja uma representação do conhecimento fragmentada, distanciada dos problemas que os educandos vivem e necessitam responder em suas vidas, mas sim solução de continuidade. Levar em conta o que acontece fora da escola, nas transformações sociais e nos saberes, a enorme produção de informação que caracteriza a sociedade atual e aprender a dialogar de maneira crítica com todos esses fenômenos (HERNÁNDEZ, 1998).

O trabalho justifica-se devido a proposta que preconiza um processo que se distancia das práticas conservadoras e compartimentadas, 
além de apresentar possibilidades de atuação que podem contribuir efetivamente com a mudança de postura em sala de aula.

Essa proposição de transformação educacional convida seus atores a percorrerem e explorarem novas possibilidades de ensinoaprendizagem, relacionarem a prática da vida humana, considerarem as questões cidadãs, respeitarem a diversidade de experiências do mundo real e recomendarem projetos com atividades que possam nortear o desenvolvimento de habilidades e competências, pois conforme afirma Perrenoud (2000) no trabalho docente é preciso, antes de tudo, trabalhar por resolução de problemas e por projetos, propor tarefas complexas e desafios que incitam os educandos a mobilizar seus conhecimentos e, em certa medida, completá-los.

O objetivo da pesquisa é instigar novos olhares para as práticas pedagógicas diante dos projetos de trabalho. Dentre os objetivos específicos são: analisar o processo dos projetos de trabalho no ambiente escolar e repensar as alternativas para as práticas pedagógicas no direcionamento dos projetos de trabalho.

A metodologia utilizada é um estudo bibliográfico, com busca em materiais científicos já publicados em livros, artigos, revistas, monografias e dissertações que abordem direta ou indiretamente o tema em análise que são os projetos de trabalho nas práticas pedagógicas. A finalidade da pesquisa bibliográfica é colocar o pesquisador em contato direto com tudo aquilo que foi escrito sobre determinado assunto (LAKATOS; MARCONI, 2001).

O estudo pontua uma abordagem a partir da investigação dos pressupostos teórico-metodológicos dos Projetos de Trabalho, contemplando o processo dos projetos de trabalho no ambiente escolar e repensando as alternativas para as práticas pedagógicas no direcionamento dos projetos de trabalho.

\section{TRAÇANDO OS PROJETOS DE TRABALHO NO AMBIENTE ESCOLAR}

Efetivamente, o método por projetos está presente na educação desde o final do século $X I X$, início do século $X X$ e muito embora mais de um século tenha se passado, suas concepções continuam em fase efervescente na atualidade (DI GIORGIO, 1992).

Com isso, difundido no Brasil, a partir do advento de renovação educacional do Movimento da Escola Nova na América Latina, o método teve início com pequenas experiências isoladas, as quais tinham em comum o fato de terem sido executadas em internatos situados no campo, onde se procurava que a educação se desse misturada com a vida dos educandos, no sentido de promover a iniciativa, criatividade e formação reflexiva na construção do 
conhecimento, em oposição à aprendizagem passiva do discente (DI GIORGIO, 1992).

Todavia, essa abordagem progressivista que advoga a ação pela ação foi inspirada e sistematizada a partir da "pedagogia ativa", sofrendo influência do filósofo John Dewey (1979).

Para esse autor, a educação era a própria vida delineada pela perspectiva do "aprender fazendo", a qual ele relaciona teoria e prática. Surgiu em contraposição aos princípios fragmentados e tradicionais da educação, além disso, suas concepções metodológicas ganharam ênfase e se intensificam como postura pedagógica que valoriza a participação ativa de docentes, discentes e suas experiências vivenciadas a partir de situações problemas, sendo amplamente disseminada por autores brasileiros como Rui Barbosa, Anísio Teixeira, Fernando Azevedo, Lourenço Filho, dentre outros intelectuais.

Ao comentar a prática pedagógica docente por projetos, Hernández (1998) descreve que podem "ser considerados uma prática educativa que teve reconhecimento em diferentes períodos deste século, desde que Kilpatrick em 1919, levou à sala de aula algumas das contribuições de Dewey", que foi considerado o maior teórico norte-americano do século XX, postulando a ideia de que "a escola é a própria vida" e que o projeto deve seguir princípios básicos e distintos que estruturem as ações docentes.

o método por projetos não é uma sucessão de atos desconexos e sim uma atividade coerentemente ordenada, na qual um passo prepara a necessidade do seguinte, e na qual um deles se acrescenta ao que já se fez e o transcende de um modo cumulativo (HERNÁNDEZ, 1998, p. 68).

Assim, está constituído por etapas e processos interconectados harmonicamente. Contudo, adotar modelos de projetos já definidos, sem considerar o planejamento, o contexto e seus atores é um risco que precisa ser evitado.

Durante a década de 30, Freinet em suas concepções pedagógicas sobre projetos, propôs repensar as relações estabelecidas em sala de aula, promovendo a cooperação e a livre expressão, neste sentido defendeu a criação de meios que suscitassem perguntas, a exemplo das "aulas passeio e dos cantinhos" (LEGRAND, 2010), tais propostas visaram promover e valorizar o desenvolvimento de trabalhos e atividades em grupo.

Com o passar do tempo, a proposta baseada em projetos foi sendo reinventada, reconstruída e reescrita, ou seja, "não se está dizendo o mesmo por se estar utilizando a expressão 'projetos', em diferentes momentos da história da educação" (HERNÁNDEZ, 1998, p. 63).

Por sua vez, os tempos são outros, sociedade, escola, formação docente e práticas educativas têm vivenciado um permanente processo de 
mudança, com isso o conceito de 'projeto' foi ganhando outros contornos e recebeu uma diversidade de denominações.

No entanto, em diferentes momentos da educação escolar, essas propostas foram (re)estruturadas no sentido de ampliar e melhorar o processo de ensino-aprendizagem, em uma perspectiva que relaciona o contexto educativo com os problemas da vida real.

\begin{abstract}
Em suas concepções educacionais Hernández (1998) também aponta que o ensino mediante "Projetos de Trabalho", "centros de interesse", "projetos interdisciplinares", "currículo integrado", "pesquisa sobre o meio", "créditos de síntese", foram algumas das iniciativas que se desenvolveram para responder, de uma maneira mais ou menos satisfatória, às mutáveis demandas e necessidades as quais a Escola deve responder (HERNÁNDEZ, 1998, p. 38).
\end{abstract}

Portanto, diante de algumas especificidades inerentes a cada proposta, o que as diferencia é a realidade do contexto histórico, cultural, econômico e social, além dos processos de pesquisa e meios de ensinoaprendizagem nos quais seus atores estão inseridos, podendo ser aplicado em diversas tendências.

Desde a pedagogia tradicional à abordagem progressista, essa variação ocorre em função da flexibilidade de (re)adaptação que os projetos possuem em relação aos diferentes contextos, a depender da postura docente e a condução de suas práticas em sala de aula, ou seja, pode-se dizer que esses processos ainda têm sido adotados, (re)constituídos e (re)interpretados por profissionais que pautam-se em diferentes referenciais pedagógicos (HERNÁNDEZ, 1998).

Para Hernández (1998, p. 67) também esclarece que em grande parte "isso acontece porque o conhecimento e a experiência escolar não são interpretadas pelos agentes educativos", essa perspectiva pode variar de acordo com as crenças, valores e metodologias daquele que de fato as aplica.

Afinal em que as práticas atuais baseadas nos projetos se diferenciam das vertentes propostas em diferentes épocas? Para responder a esse questionamento, Hernández (1998) descreve alguns aspectos relevantes, dentre eles a interdependência entre países e culturas; um desenvolvimento tecnológico que permite trabalhar com múltiplas fontes e sistemas de informação; as concepções psicopedagógicas sobre o ensino-aprendizagem; a relação entre o saber das disciplinas e o conhecimento escolar e a função da escola.

Com tantas diferenças contextuais, nesta pesquisa optou-se por adotar o conceito "Projetos de Trabalho", que para Hernández (1998) apresentam-se não como método ou uma pedagogia, mas como uma concepção da educação e da escola. E foi a partir dessa proposta de ensino- 
aprendizagem, que preconiza a inovação e a intensificação das demandas educacionais, que a inserção dos Projetos de Trabalho delineada por Hernández (1998) tornou-se uma possibilidade educativa que pretende nortear e fundamentar a ação docente, apontando para outra maneira de representar o conhecimento escolar baseado na aprendizagem da interpretação da realidade, orientada para o estabelecimento de relações entre a vida dos alunos e professores e o conhecimento que as disciplinas (que nem sempre coincidem com o das disciplinas escolares) e outros saberes não disciplinares vão elaborando.

Tudo isso para favorecer o desenvolvimento de estratégias de indagação, interpretação e apresentação do processo seguido ao estudar um tema ou um problema, que, por sua complexidade, favorece o melhor conhecimento dos alunos e dos docentes de si mesmos e do mundo em que vivem (HERNÁNDEZ, 1998, p. 91).

Destarte, tanto os métodos de projetos delineados por Dewey (1979), quanto os Projetos de Trabalho defendidos por Hernández (1998) têm como lócus uma (re)significação do espaço educativo, em uma perspectiva que dá ênfase à construção ativa do conhecimento, e embora as propostas supracitadas tenham semelhanças conceituais, ambas estão imersas em diferentes momentos históricos, sociais e culturais.

$\mathrm{Na}$ tentativa de aproximar a escola à vida diária do discente, na primeira versão de elaboração de um projeto, Dewey (1979) defendeu quatro condições, intituladas "ocupações construtivas" (Figura 01) que sustentam sua viabilidade por meio da multiplicidade de atividades e do uso adequado de diferentes materiais, são elas: 1) o projeto deve partir do interesse dos discentes; 2) considerar seu valor intrínseco e que tenha real significado para seu processo de ensino-aprendizagem; 3) a promoção de uma situaçãoproblema que desperte a curiosidade e o desejo de continuar a aprender e 4) além de considerar que o processo esteja vinculado a uma margem de tempo que pode estar para além do tempo e espaço escolar.

Figura 1. Ocupações construtivas dos Projetos. 


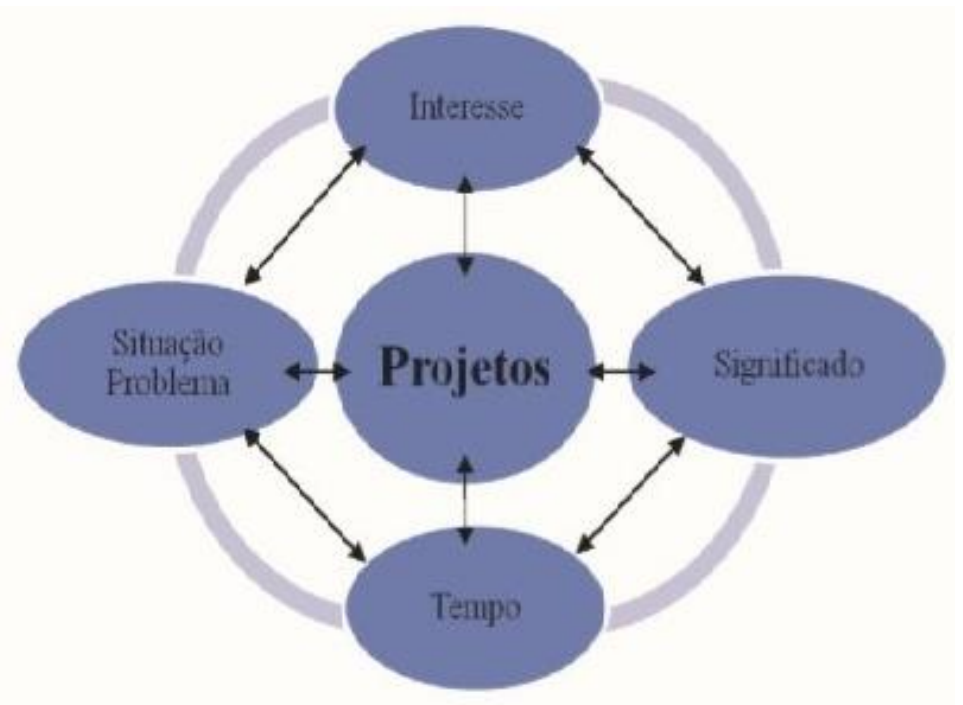

Fonte: Dewey (1979, p. 2).

A partir das palavras estruturadas com base nas concepções teórico-metodológicas em torno desta temática, pode-se inferir que o Projeto de Trabalho é uma concepção educacional que contribui para reflexões coletivas baseadas em situações reais sobre a perspectiva social, política e educacional, ou seja, uma postura pedagógica que considera temas e problemas relevantes aos discentes, pois ao se trabalhar com projetos "não se trata apenas de uma técnica atraente para transmitir aos alunos o conteúdo das matérias, significa de fato uma mudança de postura, uma forma de repensar a prática pedagógica e as teorias que Ihe dão sustentação" (HERNÁNDEZ, 1998, p. 23), contribuindo para promover transformações significativas no processo de ensinoaprendizagem. A priori, a abordagem por Projeto de Trabalho proposta por Hernández (1998), pode surgir tanto do docente quanto do discente.

Figura 2 - Ideias para sistematizar os Projetos de Trabalho. 


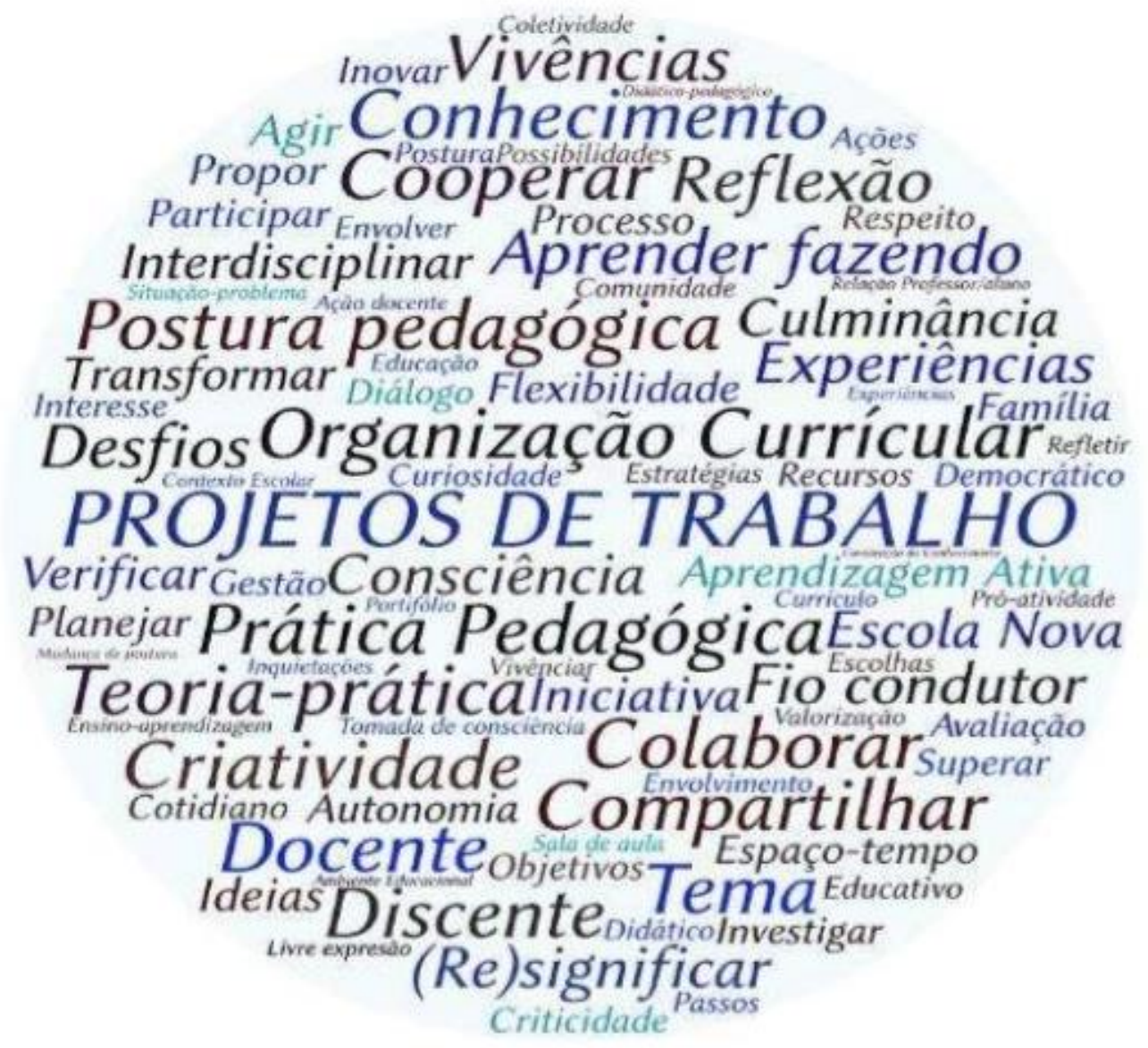

Fonte: Hernández (1998, p. 6).

Baseando na Figura 2, o importante nessa abordagem não é de onde veio a questão central, mas o tratamento dado ao problema. Essa realidade de atuação, demanda de ambos desenvolver um perfil investigativo, que valorize a (re)construção reflexiva de conceitos, além da seleção de procedimentos e técnicas consistentes e adequadas a cada situação de aprendizagem (HERNÁNDEZ, 1998).

Com isso, a escola pretende "valorizar nos alunos a autonomia pessoal, o senso crítico, os valores laicos e éticos, assim como o senso da democracia e da participação". Nesse processo de interação, o discente em contato com atividades desafiadoras desenvolverá um perfil proativo, estará diante de situações de aprendizagens significativas e cada vez mais complexas, terá iniciativa para tomar decisões, conhecerá diferentes pontos de vista, estará apto a contextualizar conteúdos e conceitos, superar diferentes obstáculos, fazer suas próprias escolhas, assumir riscos, aprender a lidar com o inesperado, conhecer novas possibilidades de construção do conhecimento, compartilhar suas descobertas e avaliar resultados obtidos (HERNÁNDEZ, 1998). 
Partindo dessa motivação inicial, para Hernández (1998, p. 67) o "ponto de partida para a definição de um Projeto de Trabalho é a escolha do tema. Em cada nível e etapa da escolaridade, essa escolha adota características diferentes". Nessa tomada de consciência é fundamental que o ato de ensinar e aprender seja intencional e significativo, possibilitando um trabalho que seja discutido, planejado, construído e compartilhado com toda a comunidade escolar. A problemática deve valorizar a participação ativa e colaborativa, motivar a investigação e promover a busca consciente por respostas.

De acordo com Dewey (1979) as metas devem ser problematizadas em função da questão a ser investigada. A partir daí, será possível definir e classificar o problema em uma relação que esteja em consonância com os objetivos educacionais do projeto, os quais precisam desafiar a participação, o envolvimento, a iniciativa, a autonomia, a curiosidade, a capacidade de discussão, a previsão de problemas e a tomada de decisão na busca por estratégias para solucioná-los.

Ademais, é importante que as hipóteses sejam investigadas, discutidas e compartilhadas coletivamente, com ampla abertura para opinar, debater, decidir e elaborar respostas, construindo uma identidade cada vez mais autônoma, corresponsável e estruturada. Nesse caminho será possível elaborar e implementar ações que propiciem a construção de conhecimentos que estejam em consonância com a realidade sociocultural dos envolvidos. As estratégias de elaboração delineadas sob orientação docente irão constituir-se problematizadoras desse processo. Assim, ao desenvolver as atividades é preciso considerar a possibilidade de reestruturação de algumas ações, do espaço e do tempo de duração de cada etapa e também de reorganização das experiências vividas, habilitando o discente a melhor dirigir o curso de experiências futuras (DEWEY, 1979).

Contudo, um fator relevante é que o estudante consciente do seu percurso investigativo aprenda a organizar e orientar seu próprio processo de ensino-aprendizagem, em uma relação de parceria e diálogo com o mestre e todos os envolvidos no projeto.

Além disso, a adequada seleção dos recursos e material de estudos é de fundamental importância para vincular conceitos, teorias e conteúdos das diversas disciplinas do currículo escolar. Quanto aos resultados é relevante ressaltar que o produto final poderá assumir formas variadas, porém, sua culminância deverá ser construída de forma cooperativa, colaborativa e compartilhada, ou seja, a socialização e a divulgação dos resultados constituem-se pressupostos elementares para (re)avaliar as ações, valorizar o envolvimento dos participantes e enfatizar o sucesso do projeto, afinal a "avaliação, é um dos temas nos quais se aprecia com mais clareza o 
sentido da inovação educativa que implicam os Projetos de Trabalho" (HERNÁNDEZ, 1998, p. 93).

Visto que, torna-se essencial uma explicação e antecipação dos critérios avaliativos, pois esse procedimento favorece 0 intercâmbio comunicativo entre os envolvidos, estabelecendo uma estratégia baseada no diálogo que permite determinar junto a turma, alguns critérios que possibilitem organizar, avaliar e autoavaliar suas próprias produções, pois "a avaliação é uma tarefa didática necessária e permanente do trabalho docente" (LIBÂNEO, 2013, p. 216).

Libâneo (2013), comenta que a organização e sistematização da avaliação deve envolver todo o grupo: docentes, discentes, gestores e comunidade escolar, precisa estar em consonância com os objetivos traçados inicialmente, confirmando e/ou reformulando hipóteses, respeitando o ritmo de ensino-aprendizagem dos educandos, além de favorecer a (re)construção de novos conhecimentos. Essa iniciativa permite facilitar a evolução consciente dos princípios educativos traçados em sala de aula e dos conteúdos de ensinoaprendizagem apontados na (re)organização curricular delineada por projetos e com base no interesse do educando.

Seguindo as especificidades dos Projetos de Trabalho, Hernández (1998) apresenta três momentos relevantes no processo avaliativo:

- avaliação inicial: contempla os conhecimentos já existentes;

- avaliação formativa: envolve todo processo avaliativo sob uma perspectiva de progressão que não pretende atribuir caráter de controle, qualificação ou classificação;

- avaliação recapitulativa: constitui-se momento de sintetizar os resultados alcançados.

Com isso, todo "o processo de avaliação pretende ser formativo, contínuo, global, adaptado à diversidade, autoavaliação e recíproco (dos alunos e do professorado)" (HERNANDÉZ, 1998, p. 41), tal perspectiva requer uma revisão constante da prática docente frente ao desafio de estruturação do conhecimento escolar construído coletivamente.

De acordo com Hernández e Ventura (1998) a compreensão das situações de ensino-aprendizagem, a partir da ótica do professorado e sem levar em conta o que os estudantes realmente aprendem conduz em determinadas ocasiões, à avaliações apressadas sobre a eficácia de uma proposta didática ou sobre o fracasso dos estudantes diante dela.

Nessa perspectiva, a eficácia dessa proposta, importa destacar que o Projeto de Trabalho não deve ser reduzido simplesmente a uma sequência fixa e rígida que deve ser seguida como uma fórmula infalível, mas pode ser considerado um fio condutor, ou seja, um ponto de partida que 
constitui-se referência para a atuação docente diante de sua perspectiva prática, vai depender da postura de cada profissional sobre a realidade escolar na qual atua, considerando todo o processo avaliativo.

Ainda sobre a questão avaliativa, Hernández (1998, p. 101) sugere ao docente a construção de portfólios, criando-se um recurso que "permite apreciar a relação das partes com o todo, e, sobretudo, é um recurso para relacionar a teoria com a prática”. Com isso, na avaliação pretende-se propor a (re)construção do processo ou a tomada de consciência de suas aprendizagens.

Hernández (1998) diz que o portfólio constitui-se elemento facilitador na reconstrução e reelaboração do processo de construção do conhecimento por parte dos discentes, neste sentido.

O que particulariza o portfólio é o processo constante de reflexão, de contraste entre as finalidades educativas e as atividades realizadas para suas consecuções, para explicar o próprio processo de aprendizagem e os momentos-chave nos quais o estudante superou ou localizou o problema (HERNÁNDEZ, 1998, p. 100).

E para que a "modalidade avaliativa" alcance seus propósitos, ao docente cabe motivar a participação, incentivar a discussão, problematizar situações de ensino-aprendizagem e socializar informações, além de sugerir etapas, confrontar ideias, registrando as práticas vivenciadas de maneira processual, qualitativa e formativa.

Assim sendo, vale destacar que cada projeto é único, ou seja, tem suas características e especificidades e deve ser elaborado exclusivamente por aqueles que de fato estarão envolvidos ao longo do processo.

Então, no âmbito do trabalho escolar, para que o discente possa construir, registrar e apropriar-se desse novo contexto de forma progressiva é preciso considerar os conhecimentos preestabelecidos, pois tais inquietações serão propulsores para novas descobertas.

Contudo, essa abordagem aponta para um constante repensar da organização curricular, priorizando o interesse dos envolvidos, a construção do conhecimento de forma significativa, além da promoção de aprendizagens ancoradas nas experiências e na vida cotidiana do discente.

2.1 Repensando as alternativas para as práticas pedagógicas no direcionamento dos projetos de trabalho

Antigamente a instituição escolar teve como pressupostos transmitir conhecimentos adquiridos de geração em geração, sendo que a ideia central era a passividade e submissão do discente à sabedoria e autoridade do 
mestre, que era o detentor do saber e condutor das técnicas de ensino; já o discente era visto como simples receptor e reprodutor de informações.

Freire (1996, p. 25) define esse modo tradicional de ensino como uma "educação bancária", ou seja, a criatividade é deformada e o discente, como espectador, não tem possibilidades de questionar, discutir e/ou criar condições que favoreçam a construção de conhecimento.

Essa proposição, cujo alicerce pressupõe uma vertente tradicional da prática pedagógica, preconiza a ênfase na instrução, memorização e imitação de modelos preestabelecidos; enfoca a reprodução e o conhecimento totalmente dissociados da realidade na qual seus atores estão inseridos; desvaloriza as reais condições do pensamento, do ritmo e do estilo de aprendizagem do educando, além de desconsiderar suas competências e habilidades diante do processo de ensino-aprendizagem, tornando-se incapaz de ampliar seu potencial criativo e assim gerar novos conhecimentos (FREIRE, 1996).

Contrapondo-se à perspectiva compartimentada, Freire (1996) aponta a importância de (re)pensar a prática educativa, que vislumbre um profissional pesquisador, pensante, ético, competente, crítico, reflexivo, curioso, dialógico, amoroso, humilde, tolerante, comunicativo, criativo, alegre, seguro e generoso. Um profissional multifacetado, que respeita os saberes e experiências do discente, que educa pelo exemplo, que incentiva a autonomia e a curiosidade, de modo que ele seja capaz de tomar decisões e tornar-se autor do seu próprio processo de formação.

Behrens (1998, p. 46) relata que "os tempos mudaram e essas práticas pedagógicas encontram-se ultrapassadas para as expectativas de uma sociedade que se renova dia a dia", e por isso requer mudanças de postura, uma revisão constante na maneira de ensinar e aprender.

Para Behrens e Flach (2008) ao final do século XX, a ciência e a Educação passam por mudanças, que aos poucos rompem o passado, vão delineando uma nova sociedade, com novos caminhos, num período caracterizado pela busca do conhecimento, pela autorrealização.

A escola tem passado por uma (re)construção das bases curriculares e educacionais, cuja dinâmica dialoga com diversas áreas do conhecimento escolar, sobretudo, apresenta possibilidades e desafios ao docente. Esse processo tem como pressuposto fundamentar a organização da escola, do currículo, das metodologias, das estratégias, do tempo, do espaço, dos objetivos da educação e da avaliação, vislumbrando atender aos anseios e expectativas de seus atores diante da demanda do processo de ensinoaprendizagem, além de sugerir um permanente (re)pensar das práticas pedagógicas (FERNANDES, 2008). 
No tocante à prática pedagógica, Fernandes (2008) aponta a importância de ser uma prática intencional de ensino e aprendizagem não reduzida à questão didática ou às metodologias de estudar e de aprender, mas articulada à educação como prática social e ao conhecimento como produção histórica e social, datada e situada, numa relação dialética entre prática-teoria, conteúdo-forma e perspectivas interdisciplinares.

A partir de uma visão interdisciplinar, mediada por relações dialógicas, "haverá necessidade de variar as estratégias tanto para motivar o aprendiz, como para responder aos mais diferentes ritmos e formas de aprendizagem, pois nem todos aprendem do mesmo modo e no mesmo tempo" (MASETTO et al., 2000, p. 142).

Neste sentido, a prática educativa deve ser intencional, planejada, sistematizada, com objetivos, metas, metodologias, recursos e instrumentos adequados à sua ação.

Numa sequência didática que segundo Zabala (1998) pode se concretizar a partir de "um conjunto de atividades ordenadas, estruturadas e articuladas para a realização de certos objetivos educacionais, que têm um princípio e um fim, conhecidos tanto pelos educadores como pelos educandos. Neste âmbito, Moran et al. (2000) destaca que:

\begin{abstract}
Alunos curiosos e motivados facilitam enormemente o processo, estimulam as melhores qualidades do professor, tornam-se interlocutores lúcidos e parceiros de caminhada do professoreducador. Alunos motivados aprendem e ensinam, avançam mais, ajudam o professor a ajudá-los melhor. Alunos que provêm de famílias abertas, que apoiam as mudanças, que estimulam os filhos, que desenvolvem ambientes culturalmente ricos, aprendem mais rapidamente, crescem mais confiantes e se tornam pessoas produtivas (MORAN et al., 2000, p. 17-18).
\end{abstract}

Ao educando cabe ser pesquisador, questionador, curioso, criativo, crítico e reflexivo, pois assim irá constituir-se sujeito histórico, social e cultural, ou seja, um indivíduo dinâmico, capaz de articular e transformar o ambiente em que atua (LIBÂNEO, 1990).

Quanto ao educador, é fundamental engajar-se no desafio de transformar suas práticas educativas, além de estar comprometido em promover uma educação de qualidade que atenda às expectativas do corpo discente (LIBÂNEO, 2013).

Tais ações devem priorizar a autonomia baseada em um ensinoaprendizagem que possa ser mediado, que valorize o conhecimento prévio, o interesse e as experiências vivenciadas, pois um novo "aprendiz" requer um profissional com perfil inovador, apto e capaz de atender suas expectativas. 
Partindo desse pensamento, o atual paradigma educacional evidencia a necessidade de promover espaços de (re)construção de conhecimento e de novos saberes, contribuindo efetivamente para (re)significar a atuação docente, pois conforme afirma Pimentel (2007) atrelada a esta concepção de mudança do paradigma está a compreensão de que o papel do profissional de educação na atualidade é o de estimular os educandos a aprenderem, a buscar e selecionar as fontes de informação disponíveis para a construção do conhecimento, analisando-as e reelaborando-as.

Behrens (2000, p. 29) fala que a ruptura de um "paradigma decorre da existência de um conjunto de problemas, para os quais os pressupostos vigentes na ciência não conseguem soluções", esse rompimento significa uma transformação na forma de compreender um determinado assunto, suas articulações, seus fundamentos e projeções diante dos novos contextos e exigências sociais. Contudo, a discussão sobre atuação docente tem sido cada vez mais recorrente no cenário acadêmico e em contextos educativos.

Nesse contexto, Luckesi (1994) destaca que a educação é concebida como prática social e serve a um projeto, a um modelo, a um ideal de sociedade. Ela medeia esse projeto, ou seja, trabalha para realizar esse projeto na prática. Assim, se o projeto for conservador, medeia a conservação; contudo se o projeto for transformador, medeia a transformação; se o projeto for autoritário, medeia a realização do autoritarismo; se o projeto for democrático, medeia a realização da democracia.

Diante das constantes influências e transformações educacionais vivenciadas nas últimas décadas, a atuação do educador exerce papel fundamental na consolidação das práticas pedagógicas por projetos e com isso, essa postura constitui-se tarefa urgente e necessária, subsidiada por novos caminhos e perspectivas teórico-metodológicas, além de mobilizar os mais diferentes saberes (MORAN et al., 2000).

Essa dinâmica aponta para uma (re)visão contínua e permanente sobre o papel das instituições, do educador e do educando.

Acrescentando que, no caminho educativo dos projetos 0 educador deve "educar para autonomia, para que cada um encontre o seu próprio ritmo de aprendizagem e, ao mesmo tempo, é importante educar para a cooperação, para aprender em grupo para intercambiar ideias, participar de projetos, realizar pesquisas em conjunto" (MORAN et al., 2000, p. 24).

Moran et al. (2000) afirma que é preciso buscar metodologias de ensino imersas na construção do conhecimento, impulsionando a reflexão, a colaboração, o diálogo e o senso crítico, como ocorre na proposta dos Projetos de Trabalho. A convergência entre a prática pedagógica docente e a construção de Projetos de Trabalho, pressupõe o desenvolvimento de uma 
perspectiva dialógica que deve ser planejada, administrada e avaliada em direção a um movimento construído socialmente, pois segundo Bender (2014, p. 9) "a aprendizagem baseada em projetos consiste em permitir que os alunos confrontem as questões e os problemas com o mundo real que consideram significativos, determinando como abordá-los e, então, agindo de forma cooperativa em busca de soluções".

Na elaboração de estratégias de ensino por Projetos de Trabalho as atividades não podem ser baseadas na visão compartimentada da repetição ou memorização, mas precisam ser reflexivas, motivadoras e articuladas. Necessitam também constituir-se de propostas didáticas que desafiem o educando a envolver-se com o processo educativo, construir saberes e apropriar-se de novos conhecimentos. Assim, as práticas educativas poderão favorecer o diálogo e o compartilhamento de ideias. Contudo, é preciso que o educador esteja atento ao percurso metodológico de sua atuação, além de estar disposto a acompanhar, orientar e avaliar a trajetória do educando (HERNÁNDEZ, 1998).

Em adição, a postura didática que inspira Projetos de Trabalho pretende promover uma reflexão na maneira de pensar e agir da escola, fornecendo subsídios para uma intervenção prática docente, em uma abordagem que respeita o ritmo, estilo, limitações e potencialidades dos educandos. Torna-se essencial (re)pensar a prática pedagógica docente, considerando as interconexões entre as diferentes áreas do conhecimento, o desenvolvimento de ações interdisciplinares, a relevância das tecnologias, o fluxo das relações, pois a "proposta educativa a que se vinculam os projetos é uma via para dialogar e dar resposta a essa situação em mudança, que não só está transformando a maneira de pensar-nos a nós mesmos, mas também de nos relacionarmos com o mundo que nos rodeia" (HERNÁNDEZ, 1998, p. 45).

Nesse sentido de elaboração e implementação de Projetos de Trabalho sob a perspectiva de (re)significar a prática pedagógica é preciso que o profissional desenvolva competências e habilidades, sobretudo atuando como facilitador, ou seja, um mediador de aprendizagens, tornando o processo educativo uma forma de aprendizagem mais significativa e prazerosa (MORAN et al., 2000).

Essa proposta demanda repensar a inserção de artefatos tecnológicos nas escolas e nas práticas pedagógicas, pois esse avanço é uma realidade cada vez mais presente na sociedade moderna, principalmente porque "as tecnologias nos ajudam a realizar o que já fizemos ou desejamos, se somos pessoas abertas, elas nos ajudam a ampliar a nossa comunicação; se somos fechados, ajudam a nos controlar mais. Se temos propostas inovadoras, facilitam a mudança" (MORAN et al., 2000, p. 27). 
Moran et al. (2000) ainda esclarece que é preciso flexibilidade para (re)avaliar as práticas em decorrência das inovações ocorridas nos últimos anos, por meio de possibilidades tecnológicas acessíveis que valorizem o ato criador, o trabalho colaborativo, a capacidade de expressão, estimulando a postura ativa do educando. Sobretudo, a instituição escolar deve estar disposta a rever seu currículo, investir na implementação desses recursos, refletir sobre os processos educativos e comunicacionais vigentes em seus espaços.

O educador depara-se com o desafio de inserir as tecnologias ao cotidiano escolar, exercendo uma tomada de consciência quanto à sua (re)utilização. Neste sentido, é preciso que o educando seja preparado para esse novo cenário, respeitado em suas especificidades e acolhido em sua individualidade, considerando a iniciativa, o protagonismo, a colaboração, a capacidade de pensar, agir, criar, argumentar, problematizar e construir novos conhecimentos. Instituição, docentes e discentes precisam preparar-se para um pleno "domínio das bases teóricas, científicas e tecnológicas, e sua articulação com as exigências concretas do ensino" (LIBÂNEO, 2002, p. 28), desta forma estarão aptos a compreender processos, mediar conflitos, propor intervenções, em uma postura aberta, crítica e disposta a refletir criticamente sobre o uso das tecnologias e sobre as ações cotidianas.

Somando que, as tecnologias por si só não garantem uma aprendizagem efetiva, ela somente terá importância se for adequada pra facilitar o alcance dos objetivos e se for suficiente para tanto. As técnicas não se justificarão por si mesmas, mas pelos objetivos que elas pretendam alcançar, que no caso serão de aprendizagem (MASETTO et al., 2000).

Integrar as tecnologias, como recurso didático sob uma perspectiva mediadora a partir de Projetos de Trabalho é uma forma de oportunizar a interação, favorecer os fluxos de comunicação, além das possibilidades de compartilhar informações, promover a troca de experiências, estimular a colaboração e facilitar pesquisas orientadas, sejam elas individuais ou em grupo, especialmente porque essa possibilidade de abordar ao mesmo tempo a atividade individual com a grupal é uma característica dos projetos que permite abordar a diversidade e os interesses de cada educando e com a qual não se homogeneíza o processo de ensino-aprendizagem (HERNÁNDEZ, 1998).

A renovação das práticas pedagógicas, demanda ter clareza de que tais recursos não o substituem, ao contrário, são aliadas das práticas pedagógicas. Essa prerrogativa é defendida por Soares (2011, p. 18) ao dizer que "com relação às tecnologias, o que importa não é a ferramenta utilizada, mas o tipo de mediação que elas podem favorecer para ampliar os diálogos sociais e educativos", visto que o potencial trazido pelas tecnologias favorece 
os fluxos comunicativos e potencializa a formação discente, estimulando-o a desenvolver um perfil autônomo, criativo e cada vez mais crítico.

\section{CONSIDERAÇÕES FINAIS}

De fato, à escola precisa (re)pensar a organização curricular frente ao desafio de ensinar e aprender por meio de projetos, visto que o docente precisa ter atitude e sensibilidade diante das inovações e adversidades dos espaços educacionais, articular suas práticas pedagógicas com ações consistentes e fundamentadas, especialmente porque o trabalho cooperativo requer abertura para (re)avaliar as formas de colaboração, comprometimento com a interação da equipe, maturidade para confrontar as diferentes opiniões, além de competência para mediar os conflitos e as relações interpessoais.

Visto que, para a construção de um projeto na escola como alternativa pedagógica é preciso delinear diretrizes e estabelecer que suas bases estejam na perspectiva do currículo integrado, no planejamento didático e no plano de aula docente.

A abordagem enfatizada nessa mudança educativa é um convite à transgressão das amarras que impeçam de pensar por si mesmo, construir uma nova relação educativa baseada na colaboração na sala de aula, na Escola e com a comunidade.

Para o sucesso da (re)organização curricular, a escola deve estar disposta a inovar processos no contexto escolar, considerando todas as vertentes do projeto curricular institucional. Para tanto, é preciso aproximar o currículo com a vida prática do discente, promovendo estratégias para organizar o conhecimento e os conteúdos de forma integrada e interdisciplinar. Esse tipo de ação inclui um (re)pensar das metodologias envolvidas, do planejamento, das estratégias de ensino, das formas de conduzir e avaliar o processo de ensino-aprendizagem, para que seja possível atender as demandas educacionais que adentram as perspectivas didáticas em sua totalidade.

Contudo, ao inserir os Projetos de Trabalho em suas práticas o educador terá subsídios para traçar metodologias de ensino, delinear critérios de planejamento, selecionar atividades que despertam 0 interesse do educando, perceber como as relações intra e interpessoais se estabelecem em sala de aula, analisar os princípios educacionais que estruturam o currículo escolar, elaborar um processo avaliativo consistente que atenda às expectativas educacionais.

\section{REFERÊNCIAS}


BEHRENS, M. A formação continuada dos professores e a prática pedagógica. Curitiba: Champagnat, 1998.

. O paradigma emergente e a prática pedagógica. 2 ed. Curitiba:

Champagnat, 2000.

DEWEY, J. Como pensamos. 4 ed. Coleção atualidades pedagógicas, v. 2, Rio de Janeiro, Editora Nacional, 1979.

DI GIORGIO, C. Escola Nova. São Paulo: Ática, 1992.

FERNANDES, C. À procura da senha da vida-de-senha a aula dialógica? Campinas: Papirus, 2008.

FREIRE, P. Pedagogia da autonomia: saberes necessários à prática educativa. 43 ed., São Paulo: Paz e Terra. 1996.

HERNÁNDEZ, F. Transgressão e mudança na educação: os projetos de trabalho. Porto Alegre: Artes Médicas Sul, 1998.

; VENTURA, M. A organização do currículo por projetos de trabalho: o conhecimento é um caleidoscópio. Porto Alegre: Artmed, 1998.

LAKATOS, E.; MARCONI, M. Metodologia do trabalho científico. 5 ed. São Paulo: Atlas, 2001.

LEGRAND, L. Célestin Freinet. Trad. José Gabriel Perissé. Recife, Fundação Joaquim Nabuco, Editora Massangana, 2010.

LIBÂNEO, J. Didática. 2 ed. São Paulo: Cortez, 2013.

Pedagogia e pedagogos, para quê?. 6 ed. São Paulo: Cortez, 2002.

LUCKESI, C. Filosofia da Educação. São Paulo: Cortez, 1994.

MASETTO, M. et al. Novas tecnologias e mediação pedagógica. Campinas: Papirus, 2000.

MORAN, J. et al. Novas tecnologias e mediação pedagógica. Campinas: Papirus, 2000. $176 \mathrm{p}$. 
PERRENOUD, P. Construir as competências desde a escola. Porto Alegre: Artes Médicas Sul, 2000.

PIMENTEL F. Formação de Professores e Novas Tecnologias: possibilidades e desafios da utilização de webquest e webfólio na formação continuada. Curso de Mídias na Educação da SEED/MEC. 2007. Disponível em: http://www.ensino.eb.br/portaledu/conteudo/artigo7771.pdf. Acesso em: 02 de ago. 2019.

SOARES, I. Educomunicação: o conceito, o profissional, a aplicação. $2^{\mathrm{a}}$ ed. São Paulo, SP: Paulinas, 2011.

ZABALA, A. A prática educativa: como ensinar. Porto Alegre: ArtMed. 1998. 


\section{O GÊNERO LÍRICO DE MARIO QUINTANA EM COLÓQUIO COM O RITMO MUSICAL E A ARTE DO MURALISTA KOBRA NUMA SEQUÊNCIA DIDÁTICA INTERDISCIPLINAR}

GARCIA, Carlos Eduardo de Campos Graduando em Letras- Uni-FACEF camposgarciacarloseduardo@hotmail.com

ANDRADE, Giovanna de Souza Graduanda em Letras- Uni-FACEF giovannasandrade345@gmail.com

COELHO, Lucinda Maria de Fátima Rodrigues Doutora em Física do Estado Sólido- Uni-FACEF lucindarcoelho@gmail.com

\section{INTRODUÇÃO}

O artigo aqui apresentado vincula-se ao Programa Institucional de Bolsas de Iniciação à Docência, que envolve os cursos de licenciatura em Letras e Matemática em uma abordagem interdisciplinar, a fim de aliar a leitura de textos literários com a linguagem matemática. O PIBID/CAPES-Uni-FACEFFranca é desenvolvido na E.E Prof. David Carneiro Ewbank e na E.E. Prof. Capitão José Pinheiro de Lacerda, assistindo os sétimos, oitavos e nonos anos do Ensino Fundamental II, com o objetivo principal de levar os estudantes a desenvolver suas competências habilidades a fim de propor uma melhor compreensão acerca dos textos literários, bem como da linguagem matemática. Para isso utilizamos sequências didáticas aplicadas ao gênero lírico, conduzindo os estudantes a uma reflexão acerca dos elementos da poesia e dos efeitos de sentido produzido, como a plurissignificação, e a subjetividade através do discurso do eu-lírico, ao desenvolver, concomitantemente, noções e conceitos matemáticos.

Foi trabalhado no semestre anterior o gênero narrativo. No primeiro semestre de 2019, com o intuito principal de envolver os estudantes num conhecimento sobre o gênero lírico, foram abordados os poemas infantojuvenis de Mário Quintana, mais especificamente "O Adolescente".

Mario de Miranda Quintana (1906-1994) foi poeta, tradutor e jornalista brasileiro. Em 1919 publicou suas primeiras produções literárias; em 1940, lançou seu primeiro livro de poesias, A rua dos cataventos, iniciando sua carreira de poeta, escritor modernista e autor infantil. Com um estilo fluido, 
introspectivo e irônico, utilizava temas como o amor, o tempo e a natureza, escrevia poesias em formato de sonetos e poemas curtos em prosa.

Além disso, foi apresentada a biografia do artista Eduardo Kobra que trata a arte como um elo entre as duas linguagens: Português e Matemática.

Carlos Eduardo Fernandes, conhecido com o nome artístico Eduardo Kobra, nasceu em São Paulo em 1975, fez parte de uma "gang" que espalhava seus rabiscos, com spray, pelos muros da cidade, antes de se tornar grafiteiro. Nos anos 90, Kobra pintava cartazes para agências de publicidade, o que provavelmente implicou a sua visibilidade na década seguinte. Em 2007, deu início ao projeto "Muro das Memórias", no qual reproduzia nas ruas de São Paulo fotos antigas da cidade. Kobra é um dos mais reconhecidos muralistas da atualidade, possui mais de 500 obras realizadas nas ruas do Brasil e de outros 17 países.

Nesta sequência didática, em que abordamos vários poemas de Mario Quintana e de maneira mais específica "O Adolescente", no qual tratamos a transição entre a infância e a adolescência. Diante disto, iniciamos com uma reflexão com os alunos sobre o tema, tirando deles suas experiências da infância e suas expectativas. Em seguida trabalhamos a estrutura do poema, e propusemos algumas produções: primeiro construíram o seu próprio poema, com o tema "A Criança", falando sobre a infância; em grupo criaram e apresentaram um ritmo musical para o poema "O Adolescente"; e por fim, uma produção envolvendo a matemática, em que os estudantes tinham como referencial o artista Eduardo Kobra que realizou uma pintura de Mário Quintana usando polígonos, e os discentes deveriam imprimir uma foto própria e nela fazer o mesmo.

Dessa forma, adotou-se, como procedimento metodológico uma pesquisa de abordagem bibliográfica, destacando-se os elementos da narrativa, noções e conceitos matemáticos. O embasamento teórico acerca de sequências didáticas está fundamentado nas reflexões propostas por Schneuwly e Dolz (2004). No que se refere à teoria da narrativa, foram utilizadas as considerações de Gancho (2006), Reis e Lopes (1988) e Reuter (2002). Os conceitos de geometria foram baseados em Dolce e Pompeo (1997) e a didática matemática em Rosa Neto (2008). Para contextualização dos artistas, foram utilizadas informações veiculadas nos sites oficiais, entre outras fontes.

\section{CONCEITUANDO SEQUÊNCIA DIDÁTICA}


O termo "Sequência Didática" (SD) surgiu em 1996, nas instruções oficiais para o ensino de línguas na França, quando pesquisadores viram a necessidade de superação da compartimentalização dos conhecimentos no campo do ensino de línguas.

"Sequência" significa "ato ou efeito de seguir", podemos dizer que são etapas continuadas de um conjunto de atividades que tem por objetivo ensinar etapa por etapa de um determinado assunto.

Dolz, Noverraz e Schneuwly (2004) apresentam um modelo de sequência didática que está basicamente estruturado e associado às pesquisas sobre a aquisição da língua escrita e gêneros textuais.

De acordo com os autores, uma "sequência didática" é um conjunto de atividades escolares organizadas, de maneira sistemática, em torno de um gênero textual oral ou escrito. As sequências didáticas servem, portanto, para dar acesso aos alunos a práticas de linguagem novas ou dificilmente domináveis.

Sequência didática é um conjunto de atividades escolares organizadas, de maneira sistemática, em torno de um gênero textual oral ou escrito a qual procura favorecer a mudança e a promoção dos alunos ao domínio dos gêneros e das situações de comunicação (Dolz, Noverraz\&Schneuwly, 2004: 53).

Toda e qualquer Sequência Didática deve ser desenvolvida para atender as necessidades dos alunos. Para todo ensinamento é necessário antes uma estratégia passo a passo para que o conteúdo seja compreendido da melhor maneira possível, então é importante que se crie e selecione sequências para ter uma didática adequada em sala de aula. É essencial saber em qual etapa os estudantes se encontram para a partir daí elaborar atividades relacionadas àquilo que eles precisam dominar, nisso entra 0 papel fundamental de um Sequência Didática.

Na Língua Portuguesa, as SDs são usadas para fazer com que o aluno aprenda de forma gradual, e compreendam passo a passo gêneros textuais. Para isso o professor pode planejar as etapas do trabalho com os alunos, de modo a explorar diversos gêneros, trabalhando a estrutura textual, desenvolvendo atividades que faça-os entender o texto, e propor no final uma produção escrita.

As etapas da realização e aplicação de uma SD de gêneros textuais consiste primeiro na apresentação do tema a qual será estudado, para que os estudantes tenham um primeiro contato com o conteúdo, logo depois de bem explicado o gênero textual pode-se desenvolver atividades que se correlacionem com o tema, dando enfoque para o vocabulário, o contexto, a estrutura e também para uma produção textual final. 
Portanto as SD são um conjunto de atividades de um tema específico ligadas entre si, etapa por etapa, com o intuito principal de facilitar o processo de aprendizagem dos estudantes.

\section{CONTEXTUALIZANDO MÁRIO QUINTANA; VIDA E OBRA}

Para dar início as nossas atividades nas escolas assistidas pelo Programa, começamos o nosso trabalho com a intenção de sensibilizar e aproximar os alunos do conteúdo que seria trabalhado durante o semestre letivo. Para tanto, fizemos, em um primeiro momento, uma sondagem para entender o que eles conheciam sobre Gênero Lírico; em seguida, foi apresentada a biografia do autor Mário de Miranda Quintana, contextualizando suas obras, com ênfase em seus poemas, principalmente os que seriam trabalhados no Programa. Posteriormente, realizou-se uma abordagem reflexiva acerca do poema $O$ Adolescente, escolhido como um dos objetos de estudo, dentro da gama de variedades que Quintana oferece. Sendo assim, por meio de pesquisas e discussões foram apresentadas, através de slides, autor e obra, para os alunos assistidos.

O escritor nasceu na cidade de Alegrete/RS, no dia 30 de julho de 1906 e veio a óbito em 05 de maio de 1994, em Porto Alegre/RS, aos 87 anos. Mario foi poeta, tradutor e jornalista brasileiro e ao decorrer de sua carreira traduziu mais de 130 obras da literatura universal, uma delas é o clássico Em busca do tempo perdido, do francês Marcel Proust, do $1^{\circ}$ ao $4^{\circ}$ volume, na Editora Globo. Além disso, trabalhou como colunista no jornal Correio do Povo, de 1953 até 1977, ou seja, grande parte de sua vida. Já em 1940, lançou seu primeiro livro de poesias, A rua dos cataventos, iniciando sua carreira de poeta, escritor modernista e autor infantil. Considerado o "poeta das coisas simples", com um estilo fluido, introspectivo, muitas vezes, irônico, marcado pela profundidade e pela perfeição técnica, utilizava de temas como o amor, 0 tempo à natureza, onde escrevia poesias em formato de sonetos, ressaltando então, o lirismo predominante em cada obra, e também realizou poemas curtos em prosa, de altíssima qualidade. Em 1980, recebe a premiação Machado de Assis da Academia Brasileira de Letras ( $A B L)$, pelo conjunto de sua obra, desde 1941, sendo o principal prêmio literário, onde o autor foi rejeitado três vezes ao tentar ingressar na $A B L$, e em 1981, foi agraciado com o Prêmio Jabuti como Personalidade Literária do Ano.

Mario possui diversas obras onde pode se destacar suas principais obras em diversos segmentos, que são; Poesias; A rua dos cataventos, 1940; Canções, 1946; Sapato florido, 1948; O aprendiz de feiticeiro, 1950; Espelho mágico, 1951; Poesias, 1962; Quintanares,1976; A vaca e o hipogrifo, 1977; Esconderijos do tempo,1980; Baú de 
espantos,1986; Preparativos de viagem,1987; Da preguiça como método de trabalho, 1987; Porta giratória,1988; A cor do invisível, 1989; Velório sem defunto,1990; Água, 2001 (publicação póstuma). Literaturainfanto-juvenil; O batalhão das letras, 1948; Pé de pilão, 1968; Lili inventa o mundo, 1983; Nariz de vidro, 1984; O sapo amarelo, 1984; Sapato furado, 1994. Antologias; Antologia poética, 1966; Prosa \& verso, 1978; Na volta da esquina, 1979; Nova antologia poética, 1981; Literatura comentada, 1982; Primavera cruza o rio, 1985; 80 anos de poesia, 1986 e Ora bolas, 1994.

Fonte:

https://www.suapesquisa.com/biografias/mario_quintana.htm

\section{CONTEXTUALIZANDO EDUARDO KOBRA; BIOGRAFIA E OBRAS:}

Como citado anteriormente, e para o desenvolvimento da Sequência Didática aqui apresentada, foi feito uma abordagem interdisciplinar, trabalhando com os estudantes a linguagem matemática, e para isso foi escolhido como objeto de estudo o artista Eduardo Kobra.

Carlos Eduardo Fernandes, conhecido com o nome artístico Eduardo Kobra, nasceu no Jardim Martinica, zona sul de São Paulo, no dia 1 de janeiro de 1975. Com 12 anos, já espalhava rabiscos pelos muros da cidade. Nessa época, fazia desenhos na escola pública em que estudava, recebendo o apelido de Cobra, pela perfeição de seu desenho.

Nos anos 90, Eduardo Kobra começou a auferir dinheiro com seu grafite, entre outros trabalhos, pintava também cartazes para agências de publicidade.

Sua arte urbana granjeia visibilidade na década seguinte. Kobra se tornou um muralista - um grafiteiro que, pelas dimensões do trabalho só consegue atuar com a permissão ou contratação dos donos do imóvel e das autoridades.

Em 2007, Eduardo Kobra começou a aparecer na mídia com o projeto "Muro das Memórias", em que passou a reproduzir, nas ruas, fotos antigas de São Paulo. O passo seguinte foi a elaboração de murais. O artista fez curso para pintar em cima de gruas. Passou a pintar murais ambiciosos.

Kobra é um dos mais reconhecidos muralistas da atualidade, possui mais de 500 obras realizadas nas ruas do Brasil e de outros 17 países. Detém o recorde de maior mural grafitado do mundo com a obra Etnias (2,5 mil metros quadrados), marca superada por ele mesmo em 2017.

A escolha deste artista para trabalhar a linguagem matemática foi devido ao uso de formas geométricas em suas obras, o mesmo sempre faz uso 
de polígonos em suas produções, e em uma delas, fez a pintura de Mário Quintana usando apenas essas formas geométricas, como mostra na foto seguinte:

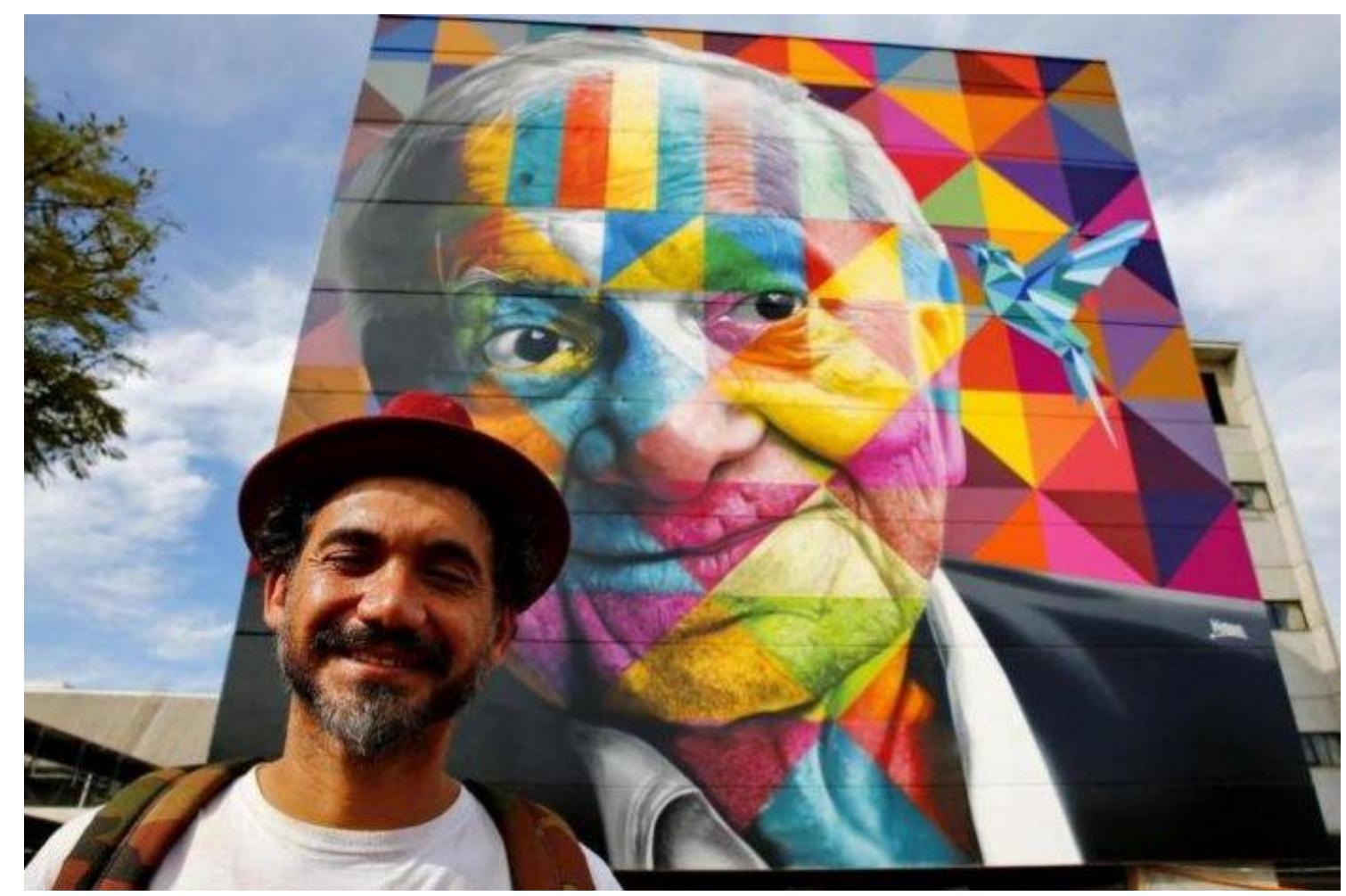

Fonte: http://www.eduardokobra.com/biografia/

\section{O ADOLESCENTE; EXPLORANDO O POEMA:}

O poema O Adolescente compõe a coletânea de poemas contidos no livro Apontamentos de história sobrenatural, publicado em 1976. Os poemas deste livro são geralmente curtos e em versos livres, mas há também sonetos e odes, bem como poemas em prosa; alguns deles foram divulgados pela primeira vez no livro Antologia, com poemas de Quintana selecionados por Rubem Braga e Paulo Mendes Campos.

Pela diversidade de temas e formas, o livro sintetiza diversas estratégias anteriormente presentes em seus poemas, retoma temas como 0 onírico e o fantástico, e formas como o soneto presente em sua obra anterior, além de inaugurar campos novos de observação, como a recuperação da infância, ou através do esquadrinhamento do imenso cotidiano que Quintana tanto quis poetizar, mesmo em suas mais ínfimas insignificâncias. Ao mesmo tempo, o aprofundamento de sua reflexão sobre o tempo e a morte, dois temas recorrentes em seus livros, em contraste com as pequenas experiências pessoais ocorridas no dia-a-dia, permite que o poeta salte além, buscando 
inventar um modo para o homem comum pensar a existência e ligar todas as coisas, das mais materiais às mais fugidias.

Fonte: https://www.passeiweb.com/estudos/livros/apontamentos_ de_historia_sobrenatural

Ao iniciarmos a análise do poema, fizemos com os estudantes uma grande reflexão em relação ao tema contido no texto, avocando as experiências dos alunos vividas na infância, e questionando-os sobre o que esperavam para a nova fase da vida que logo viveriam, a adolescência. Logo depois realizou-se a leitura do texto, identificando as palavras desconhecidas e encontrando seu significado para uma melhor compreensão.

A imagem seguinte mostra as palavras desconhecidas, já com seus respectivos significados:

\section{VOCABULÁRIO E CONTEXTO:}

1) Para que o leitor compreenda bem um texto literário, é necessário que ele conheça o sentido das palavras em seus contextos; portanto, com a ajuda de um dicionário, pesquise e transcreva para o seu "caderno" o significado das seguintes palavras:

- súbita - sitwocáo, unespe vada

- fremente - furovido de comocoio

- fascinante - Rego que atrou le uncounta

- farejar - Aupiar u cheino

- cumplicemente - Que foroure a viealizocos de alogs.

O texto inicia-se falando do medo, mas não um medo ruim, mas o medo daquilo que ainda é desconhecido, do que está por vir. E diz mais, é um medo que faz com que o jovem tenha curiosidade se seguir em frente para descobrir novas coisas, e conhecer o novo, traz curiosidade e inquietação, e o desejo de saber mais.

A vida é tão bela que chega a dar medo. Não o medo que paralisa e gela, estátua súbita[...]

(QUINTANA, 1976, primeira e segunda estrofe).

Seguindo a reflexão, é possível identificar no texto o predomínio de figuras de linguagem, que dá um sentido mais figurado ao poema. $\mathrm{Na}$ terceira estrofe o eu-lírico compara o adolescente com um "felino", uma comparação implícita usando a figura de linguagem metafórica para fazer uma alusão a um filhote de felino, que quando pequeno busca conhecer tudo ao seu redor, meio atrapalhado, mas com desejo de descobrir, sem saber o que vai enfrentar, comparando assim o jovem que está nessa fase de transição.

Logo mais diz que esse jovem felino fareja o vento, quando sai à primeira vez da gruta. Mais uma figura de linguagem usada pelo autor, que mostra a mudança na vida do adolescente, que antes vivia sob uma proteção, 
(que é a "gruta") e agora sai e vai "farejar o vento", descobrir coisas novas por conta própria, sem precisar de ajuda, de proteção. Isso marca a transição da infância para a adolescência.

Quando o autor diz sobre "farejar o vento" nos remete novamente ao felino, pois um animal, quando está em sua fase de transição o olfato é o principal sentido para que ele conheça e se lembre do que conheceu.

[...] esse medo fascinante e fremente de curiosidade que faz o jovem felino seguir para frente farejando o vento ao sair a primeira vez da gruta. [...] (QUINTANA, 1976, terceira estrofe).

Na próxima estrofe o eu-lírico volta falar do medo, mas um medo diferente do que ele cita no início do texto, agora esse é um medo que ofusca. Ofuscar significa impedir a visão, ele faz novamente essa comparação implícita para remeter-se novamente as descobertas, que são tantas, tanta coisa nova, que o adolescente acaba ficando confuso, ofuscado, e não consegue entender direito o que está acontecendo, sua luz é ofuscada.

Nesta estrofe, vemos o uso da figura de linguagem paradoxal, a luz que faz enxergar, mas é ofuscada e impede a visão.

[...] Medo que ofusca: Luz![...] (QUINTANA, 1976, quarta estrofe).

Iniciando a quinta estrofe, o autor usa novamente uma figura de linguagem, desta vez, a personificação, ou conhecida também como prosopopéia, que consiste em atribuir sentimentos e ações próprias dos seres humanos a seres inanimados ou irracionais. Esta figura de linguagem é usada quando o eu-lírico diz

"[...]Cumplicimente, as folhas contam-te um segredo Velho como o mundo[...]"

Nesta estrofe o autor quer dizer que assim como o jovem está se abrindo para novas descobertas, a natureza também abre-se a ele para "contar-lhe" os segredos da nova etapa a ser vivida.

Por fim, o eu-lírico encerra chamando a atenção do jovem que já é um adolescente, dizendo que agora ele deve ter um olhar diferente para a vida, pois é algo novo, e do mesmo modo é feito uma comparação implícita, comparando a vida nova com a nudez, "[...] A vida é nova e anda nua [...]", está nua, pois precisa ser vestida, e será vestida de acordo com as decisões do 
adolescente, ele que vai da direcionamento para essa "nova vida", de acordo com os seus desejos, escolhas, decisões, assim a vida será vestida.

"[...] Adolescente, olha"! A vida é nova...

A vida é nova e anda nua Vestida apenas com o teu desejo! (QUINTANA, 1976, ultima estrofe).

Encerramos a reflexão reforçando sobre as escolhas, que são muito importantes nessa fase da vida, pois aquilo que decidem agora terá reflexo no futuro.

\subsection{Estrutura do poema}

O poema possui uma estrutura composta por catorze versos divididos em seis estrofes. O autor usa um esquema de versos livres, denominado também pela língua portuguesa de versos irregulares, estes apresentam uma métrica variada, em que o autor pode "brincar" com as estrofes, e as mesmas terão sentido, e ritmo.

Neste poema, é possível identificar um ritmo a cada verso, isso acontece devido a variação da métrica.

Ritmo: São os elementos sonoros. O ritmo está ligado intimamente a ideia de alternância, alternância de som e silêncio, de graves e agudos. Assim, em poesia, o ritmo se dá pela alternância de sílabas acentuadas e não acentuadas, ou seja, sílaba com maior ou menor intensidade

Métrica: Chamamos métrica a medida dos versos, não são as sílabas tomada em relação umas as outras, mas os segmentos rítmicos que permitem variar a modulação e adaptá-las as necessidades expressivas. 
estruturado:

Na figura seguinte, podemos ver a forma como o poema é

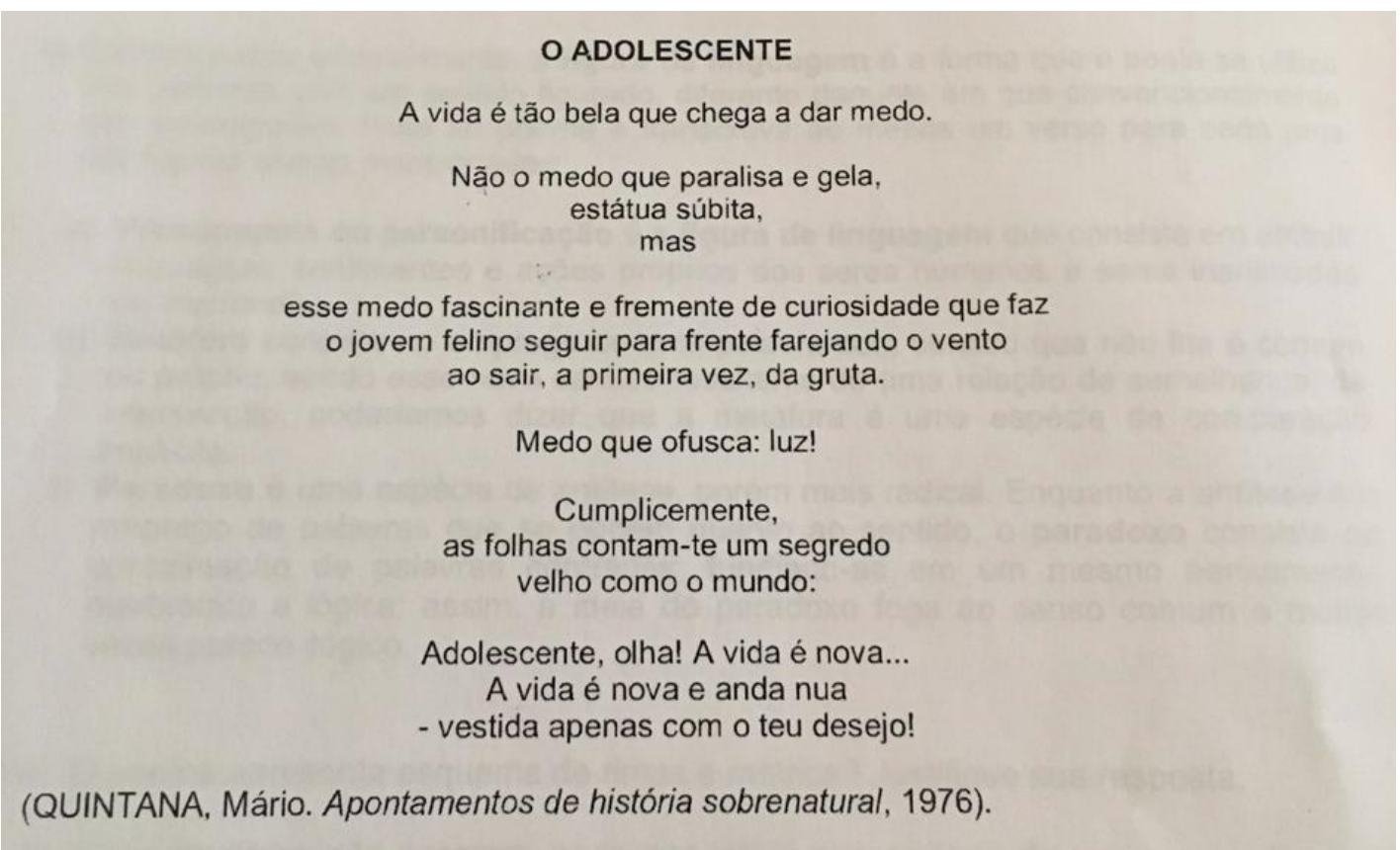

\section{DESCREVENDO AS ATIVIDADES RELACIONADAS À SEQUÊNCIA DIDÁTICA:}

Com subsídio do poema, os estudantes trabalharam o vocabulário e o contexto, de início identificando as palavras desconhecidas, como já citado anteriormente e logo depois destacaram o sentido que mais se aplicava ao texto.

1-Para que o leitor compreenda bem um texto literário, é necessário que ele conheça o sentido das palavras em seu contexto; portanto, com a ajuda de um de um dicionário, pesquise e transcreva para o seu "caderno" o significado das seguintes palavras:

-súbita

-fremente

-fascinante

-cumplicemente

2-Agora destaque da sua pesquisa o sentido que melhor se aplica a cada uma dessas palavras no contexto do poema.

3-Assinale a alternativa que melhor representa o sentido da palavra "medo", que aparece por quatro vezes no poema:

a) coragem 
b) covardia

c) pavor

d) insatisfação

e) desconhecimento

Encerrada a parte de vocabulário, iniciamos as atividades relacionadas a estrutura do texto, aprofundando o conhecimento dos alunos em relação as figuras de linguagem. Foi dado ênfase as que estavam inseridas no texto, e pediu-se a identificação de cada uma delas.

4) Conforme visto anteriormente, a figura de linguagem é a forma que o poeta se utiliza das palavras com um sentido figurado, diferente daquele em que convencionalmente são empregadas. Volte ao poema e transcreva ao menos um verso de cada uma das figuras abaixo mencionadas:

a) Prosopopéia ou personificação é a figura de linguagem que consiste em atribuir linguagem, sentimentos e ações próprias dos seres humanos a seres inanimados ou irracionais.

b) Metáfora consiste no emprego de uma palavra com sentido que não lhe é comum ou próprio, sendo esse novo sentido resultante de uma relação de semelhança, de intersecção, poderíamos dizer que a metáfora é uma espécie de comparação implícita.

c) Paradoxo é uma espécie de antítese, porém mais radical.

Enquanto a antítese é o emprego das palavras que se opõe quanto ao sentido, o paradoxo consiste na aproximação de palavras contrárias, fundindo-as em um mesmo pensamento, quebrando a lógica.

Terminadas as atividade sobre a estrutura do texto e as compreensão do poema, foi oferecido aos estudantes algumas propostas de produções dos próprios alunos, dentre estas produções estavam inseridas, uma escrita, em que o estudante seria o autor, escrevendo seu próprio poema com o tema "A criança", falando sobre infância; a segunda produção foi em grupo, em que deveriam criar um ritmo musical para o poema de $O$ Adolescente; e por fim, em uma abordagem interdisciplinar, os estudantes novamente foram os artistas, usando como subsídio o artista Eduardo Kobra, utilizaram uma foto própria, impressa, e sobre ela desenharam polígonos, assim como Kobra fez em sua obra em homenagem a Mário Quintana.

1) Seguindo a estrutura do texto, escreva um poema com o título "A criança", em que o eu-lírico fale sobre a infância

2) Em duplas, ou trios, criem um ritmo musical para o poema "O adolescente", de Mário Quintana, e em seguida, apresentem a sala. Usem sons produzidos não apenas por instrumentos musicais (violão, flauta, violino, etc), como também pelo corpo (pés, mãos, boca, etc)

3) Agora o artista é você... Pensando no mural feito por Kobra em homenagem a Mario Quintana, crie você o seu próprio mural. 
A proposta é que você utilize uma foto sua xerocada em preto e branco (ou uma ilustração de seu rosto), e acrescente uma ilustração que represente um de seus sonhos (no caso da obra de Kobra havia o "pássaro" de Quintana).

Faça os polígonos e pinte-os, de acordo com sua preferência.

E com estas atividades, encerramos nossa sequência didática.

\section{CONSIDERAÇÕES FINAIS}

Conforme dito anteriormente, o artigo aqui apresentado vincula-se ao Programa Institucional de Bolsas de Iniciação à Docência, PIBID/CAPESUni-FACEF- Franca-SP, que em uma abordagem interdisciplinar, envolve os cursos de licenciaturas em Letras e Matemática, com o objetivo principal de desenvolver competências e habilidades para a leitura de textos literários, bem como da linguagem matemática apresentada em situações-problema.

A partir da leitura da obra de Quintana foi possível trabalhar todos os conteúdos propostos, tanto em Língua Portuguesa, quanto em Matemática, de forma crítica e reflexiva, propiciando aos alunos a ampliação de horizontes pretendido à interação leitor/texto. Ao longo do semestre, foi possível perceber a evolução dos discentes na apreensão e assimilação dos conteúdos aplicados às atividades sistematizadas, que envolvem os componentes básicos do ensino de língua: leitura, análise linguística e semântica, além da produção textual.

Quanto à abordagem interdisciplinar, faz-se necessário dizer sobre o enriquecimento adquirido por meio das reflexões e discussões propostas, permitindo que os alunos percebessem que, para entender Matemática, ciência das exatas, há que se entender, primeiro, o Português.

Assim, acreditamos que o trabalho interdisciplinar instiga a curiosidade e promove o interesse e o comprometimento dos discentes, levando - os a uma nova perspectiva sobre como correlacionar duas ciências opostas. Fato que comprovamos juntamente aos estudantes, visto que tanto no âmbito didático e pessoal houve uma evolução aplausível.

\section{REFERÊNCIAS}

CANDIDO, Antônio. O estudo analítico do poema. 5. ed. São Paulo: Humanitas, 2006. p. 61-94 
CEREJA, Wiliam Roberto e MAGALHÃES, Tereza Cochar. Literatura brasileira. São Paulo: Atual, 1995.

DOLCE, Osvaldo; POMPEO, José Nicolau. Fundamentos de Matemática Elementar. Geometria Plana. vol. 9. São Paulo: Atual, 1997.

DOLZ, J; NOVERRAZ, M.; SCHNEUWLY, B. Sequências Didáticas para o oral e a escrita: apresentação de um procedimento. In: - Gêneros orais e escritos na escola. Tradução e organização Roxane Rojo e Glais Sales Cordeiro. Campinas, SP: Mercado de Letras, 2004, p. 81 - 108.

KAYSER, Wolfgang. Análise e interpretação da obra literária.6. ed. Revisão Paulo Quintela. São Paulo: Martins Fontes, 1976.

GOLDSTEIN, Norma. Versos, sons, ritmos. 14. ed. São Paulo: Ática, 2006

GUIMARÃES, Helio de Seixas; LESSA, Ana Cecília. FIGURAS DE LINGUAGEM: TEORIA E PRATICA. 11. ed. São Paulo: Atual, 1988.

ROSA NETO, Ernesto. Didática da Matemática. 11. ed. São Paulo: Ática, 2008.

ROSENFELD, Anatol. O teatro épico. 4. ed. São Paulo: Perspectiva, 2002.

Releituras- Biográfico e Bibliográfico. Disponível em: <http://www.releituras.com/mquintana_bio.asp>. Acesso em: 28 de ago.2019 Cronologia da Vida e Obra de Mario Quintana. Disponível em: <http://www.ccmq.rs.gov.br/novo/mario/cronologia.php>. Acesso em: 28 de ago.2019

Mário Quintana. Poesia completa. Disponível em: $<$ http://www2.fw.iffarroupilha.edu.br/biblioteca/wpcontent/uploads/2017/08/POESIA_COMPLETA_MARIO_QUINTANA.pdf.> Acesso em: 28 de ago.2019.

Eduardo Kobra- Biografia. Disponível em: <http://www.eduardokobra.com/biografia/>. Acesso em: 28 de ago.2019 


\title{
OS PRINCÍPIOS DA EDUCOMUNICAÇÃO: DIÁLOGANDO ENTRE COMUNICAÇÃO E EDUCAÇÃO
}

\author{
GONÇALVES, Gustavo Henrique \\ Mestre em Saúde e Educação - UNAERP \\ gustavonatacao@yahoo.com.br
}

TAVARES, Graciele Faine Especialista em Psicopedagogia - Centro Universitário Claretiano

gracielefaine@gmail.com

CLEMENTE, Guilherme Augusto Bertelli Fernandes

Doutorando em Ciências - UNIFRAN engenheirocivilguilherme@yahoo.com.br

\section{INTRODUÇÃO}

Primeiramente, a escola é um ambiente de aprendizagens e construção de conhecimentos, um espaço de vivências que tem como objetivo promover a formação necessária ao desenvolvimento dos educandos, preparando-os para o pleno exercício da cidadania, pois assim serão capazes de compreender, dialogar e intervir na realidade em que atuam, com isso aponta que:

\begin{abstract}
a escola precisa estar consciente dos fatores que a envolvem, ou seja, formar para o mercado competitivo, orientado pela lógica do mais forte, ou formar cidadãos para sociedade democrática e de oportunidade para todos? Buscar o equilíbrio entre esses dois aspectos é tarefa complicada, mas urgente. E é no trabalho com comunicação/educação que se poderá enfrentar de maneira mais explícita tal desafio (FÍGARO, 2010, p, 10).
\end{abstract}

Todavia, percebe-se que com o passar do tempo, modifica-se a realidade social e educacional, os princípios, as formas de ensinar e aprender, ou seja, para cada contexto histórico novas propostas educativas emergem, suscitando um constante (re)pensar do papel da escola.

Nesse desafio, que aflora a partir da relação entre comunicação e educação, educar-se no espaço escolar é "participar de um processo formado por uma rede de múltiplos fluxos comunicativos" (KAPLÚN, 1999, p. 68), empreendendo esforços para desenvolver competências, além de promover o diálogo e a participação.

Em adição, a comunicação é um processo transformador que pode contribuir com a escola no sentido de potencializar a relação dialógica 
entre família, discentes, docentes, comunidade e os diferentes grupos sociais imersos nesse contexto social.

Considerado um dos idealizadores da Educomunicação, o autor apresenta a seguinte definição para o termo:

processo educativo que permite aos alunos apropriarem-se
criativamente dos meios de comunicação; integrar a voz dos
estudantes ao Ecossistema Comunicativo da escola e, em última
instância melhorar a gestão do ambiente escolar com participação
dos educandos (VOLPI; PALAZZO, 2010, p. 08).

Diante desse olhar, que dá voz ao educando, o autor aponta que a mediação nos ambientes educativos torna-se estratégia central no processo de desenvolvimento humano, permitida através da criatividade, da interação, da reflexão e da crítica, potencializando a gestão do ambiente educacional.

O objetivo do trabalho é observar os princípios da Educomunicação, através dos diálogos entre comunicação e educação. Dentre os objetivos específicos, são: entender as interconexões entre a Comunicação e Educação, analisar um panorâmico histórico da Educomunicação e compreender as perspectivas trilhadas $e$ as novas possibilidades da Educomunicação.

A metodologia empregada é de revisão bibliográfica, com dados qualitativos, ou seja, por intermédio de explicações fundamentadas em trabalhos publicados sob a forma de livros, revistas, artigos, e publicações especializadas na questão e demais informações que abordem direta ou indiretamente o tema em análise que foi a Educomunicação. A finalidade da pesquisa bibliográfica foi colocar o pesquisador em contato direto com tudo aquilo que foi escrito sobre determinado assunto (LAKATOS; MARCONI, 2001).

O trabalho buscou-se aprofundar o conceito, os fundamentos e a perspectiva histórica da Educomunicação como uma área do conhecimento, a fim de compreender as interconexões do diálogo entre comunicação e educação, além de apontar caminhos e possibilidades para subsidiar ações Educomunicativas nos espaços de ensino-aprendizagem no cotidiano escolar.

\section{AS INTERCONEXÕES ENTRE A COMUNICAÇÃO E EDUCAÇÃO}

$\mathrm{Na}$ prática comunicativa constitui-se uma atividade dinâmica, presente no cotidiano de seus atores, permitindo-Ihes a livre expressão, além da construção de valores, princípios, crenças, leis, costumes e processos culturais, pois o ser humano constrói e é construído no e pelo processo cultural (SOARES, 2011). 
Acrescentando que, é produtor da cultura e é produto da cultura, apesar da relevância social e cultural da comunicação, o autor também destaca que o espaço escolar deixou de ser o único lugar de legitimação do saber, pois existe uma multiplicidade de saberes que circulam por outros canais, difusos e descentralizados. Essa diversificação e difusão de saberes, fora da escola, é um dos desafios mais fortes que o mundo da comunicação apresenta ao sistema educacional (SOARES, 2011).

Diante destas reflexões, as temáticas relacionadas à comunicação e educação transcendem os muros da escola, pois seus valores estão além da educação escolar. É por meio do intercâmbio cultural e comunicacional nos espaços formais, informais e não formais da educação, que os indivíduos interagem uns com os outros, desenvolvem um sistema de signos, criam símbolos, trocam ideias, compartilham experiências, tomam decisões, exprimem seus desejos, relacionam saberes, partilham conhecimentos, ou seja, é nessas relações que adentram os processos de ensino e aprendizagem que a comunicação se faz presente (SOARES, 2011).

Schaun (2002, p. 30) demonstra que "a comunicação está em tudo. Tudo é comunicação transitado num pântano invisível, transparente, entre linguagens, palavras, discursos, sons, falas, imagens, narrativas", que se legitima num processo fluido e onipresente, que possibilita aos seres humanos dialogar, viver em sociedade e construir sua própria visão de mundo.

Por sua vez, a compreensão através das diferentes linguagens está presente nas relações, carregado de significados, objetivos, finalidades e intencionalidades, pois os códigos expressos nesses processos representam pensamentos, desejos e sentimentos, assim é possível consolidar relações interpessoais que permitam aos sujeitos trocar, enviar, receber e compreender mensagens, (re)modelando as diferentes formas de ensinar e aprender (SOARES, 2011).

Sucessivamente, Koch (2003) comenta que a importância de compreender a linguagem não simplesmente como representação do mundo, do pensamento humano ou mero instrumento de comunicação, sobretudo, como importante fonte de interação social. A partir desta relação entre os sujeitos sociais e a escola, como espaço formal de aprendizagens, precisa estar disposta a se (re)organizar, construir novos currículos, (re)ver metodologias, atualizar suas práticas, além de incentivar a participação e a livre expressão de todos os envolvidos, visto que muitos desses fatores dependem de uma boa relação entre comunicação e educação.

Diante do exposto, Schaun (2002) destaca que a educação é um processo específico e exclusivamente humano, tal abordagem permite ao sujeito optar por um modo de vida que transforme suas ações, permitindo-lhe decidir, criar, recriar e além disso, comunicar-se. 
Para a autora, ao elencar a palavra comunicar-se assume o entendimento de uma filosofia educacional necessária e irrevogavelmente voltada para a comunicação entre os homens, no âmago da construção de devires, e inspirada nas experiências culturais.

Conforme Schaun (2002, p. 79) ao mencionar que "o paradigma da educação no seu estatuto de mobilização, divulgação e sistematização de conhecimento implica acolher o espaço interdiscursivo e mediático da comunicação como produção e veiculação da cultura", vivenciando na prática um diálogo educativo aberto entre diferentes vozes que dialogam entre si, especialmente por estarem conectadas pelos meios e suas perspectivas comunicativas.

Nessa perspectiva, Gadotti (2007, p. 07) diz que "educação e comunicação são processos inseparáveis e a relação entre eles é complexa". Diante dessa proximidade, a comunicação constitui-se fator preponderante para o processo educativo, e vice-versa, pois conforme afirma Schaun (2002, p. 100), "comunicar para a educação e educar para comunicação, são processos inter-relacionados", que se integram e se expandem de forma permanente.

Com isso, está interconexão entre comunicação e educação, pode contribuir para abrir diálogos e compreensões entre diferentes culturas e gerações, integrar espaços coletivos e interativos que permitam a "alteridade" entre seus atores, ou seja, uma maior conexão entre as "múltiplas vozes que polemizam entre si, interagem, dialogam e/ou se complementam" (SCHAUN, 2002, p. 92), com vistas a promover a construção coletiva do conhecimento.

No contexto brasileiro, a convergência entre essas duas áreas foi amplamente defendida na abordagem de Paulo Freire (1988), cuja filosofia ampara-se em princípios éticos bem explícitos, de uma alfabetização apoiada no diálogo e nas mais diversas culturas. Contudo, as transformações almejadas por essa vertente somente serão consolidadas se todos os sujeitos estiverem envolvidos no processo.

\begin{abstract}
a comunicação verdadeira não nos parece estar na exclusiva transferência ou transmissão do conhecimento de um sujeito a outro, mas em sua coparticipação no ato de compreender a significação do significado. Esta é a comunicação que se faz criticamente (FREIRE, 1988, p. 70).
\end{abstract}

Num processo educativo que se concretiza pelo diálogo, reflexão e transformação de novos conhecimentos ressalta que "a educação é comunicação, é diálogo, na medida em que não é transferência de saber, mas um encontro de sujeitos interlocutores" (FREIRE, 1988, p. 69).

Com este cenário de transformação, uma das facetas da relação entre educação e comunicação é a utilização de recursos tecnológicos 
midiáticos, que trouxeram em seu bojo a imersão em um novo tempo, intitulado "era da informação" (CASTELLS, 1999).

Castells (1999, p. 51) fala que "não são simplesmente ferramentas a serem aplicadas, mas processos a serem desenvolvidos". Segundo o autor, o resultado de qualquer ação pedagógica na "sociedade em rede" não deverá centrar-se no produto, sobretudo na compreensão de todo o processo educacional, gerando outros valores e construindo novas aprendizagens.

Conforme Fígaro (2010, p. 10) pontua que "o primeiro desafio do campo comunicação/educação é o de como abordar a lógica que envolve as tecnologias da comunicação no espaço da escola na sociedade contemporânea".

Visto que, faz-se importante estar atento ao uso adequado desses artefatos sem desvirtuá-los de uma prática docente consciente, que considere todas as suas potencialidades pedagógicas. No que concerne a educar na "era da informação" Gutiérrez (1996) sugere que a escola contemporânea esteja centrada mais na sensibilidade humana do que em uma racionalidade abstrata e distante.

Como espaço de construção de saberes e diferentes culturas, a instituição deve estar atenta às mudanças que adentram a sociedade da informação e impactam diretamente em suas ações. No âmbito de suas atribuições necessita passar por uma urgente reformulação didática, pois:

a escola é um lugar de ensino e difusão do conhecimento, é instrumento para 0 acesso das camadas populares ao saber elaborado. É, simultaneamente, meio educativo de socialização do aluno no mundo social (LIBÂNEO, 1990, p. 75).

De fato, a comunicação entrelaçada à educação, tende a fazer parte do ambiente educacional e da sala de aula, constituindo-se elemento facilitador nas relações humanas, que pressupõe, sobretudo, estar imerso em uma realidade que viabiliza ações participativas, interativas e dialógicas.

No pensamento de Citelli (2000, p. 17) mostra que estes dois campos "passam a ser vistos como sequências de um processo cada vez mais inter-relacionado: requisitam-se para esclarecerem-se, pedem-se para que nenhum dos termos ganhe autonomia a ponto de ressoar". Em suas concepções sobre o diálogo entre comunicação e educação, o autor destaca ainda, a importância da "reorientação dos modos de ver, sentir, conhecer e saber o que singulariza os processos formadores no mundo contemporâneo" (CITELLI, 2000, p. 21).

Todavia, quando essas duas áreas estiverem efetivamente em consonância com os propósitos educacionais será possível promover uma 
abordagem de construção de saberes de maneira crítica, reflexiva e transformadora.

Nesse sentido é importante destacar que os dois campos "jamais poderiam integrar-se, sob a suspeita de estarem perdendo sua identidade e sua razão de ser" (SOARES, 2011, p. 121). Ademais, no intuito de estabelecer bases sólidas sobre a interconexão entre comunicação e educação, destaca a perspectiva educomunicativa que trabalha

\begin{abstract}
a partir de um substrato comum, que é a ação comunicativa no espaço educativo, ou seja, a comunicação inter-pessoal, grupal, organizacional e massiva promovida com o objetivo de produzir e desenvolver ecossistemas comunicativos através da atividade educativa e formativa (SOARES, 1999, p. 35).
\end{abstract}

A priori, a convergência entre esses dois contextos abre precedentes para a implementação de uma comunicação educativa que potencializa uma sociedade educativa. É possível favorecer a construção do conhecimento à medida que essa proposta ultrapassa os limites da sala de aula. Ainda nessa perspectiva defende que:

\footnotetext{
a comunicação educativa abarca certamente o campo da mídia, mas não apenas esta área: abarca também, e em lugar privilegiado, o tipo de comunicação presente em todo processo educativo, seja ele realizado com ou sem o emprego dos meios. Isso implica considerar a Comunicação não como um mero instrumento midiático e tecnológico, e sim, antes de tudo, como um componente pedagógico (KAPLÚN, 1999, p. 68).
}

Portanto, diante desta interconexão, que eleva o potencial pedagógico da comunicação, destaca-se a importância de se utilizar o potencial comunicativo a favor da educação integral, promovendo uma prática social focada na linguagem dialógica, empregando recursos e estratégias que valorizem a colaboração e possibilitem a interação, além de fomentar a construção de uma nova área de conhecimento (SOARES, 2011), ou seja, um novo campo de intervenção social (SCHAUN, 2002) que emerge da interconexão e da relação entre comunicação e educação, que neste lócus intitula-se Educomunicação.

Então, o que é Educomunicação? Qual sua perspectiva histórica? É possível abordar suas concepções nos espaços educacionais?

\title{
2.1 Um panorâmico histórico da Educomunicação
}

Inicialmente, para pontuar sobre a temática buscou-se dialogar com autores que abordam a comunicação e a educação como elementos estruturantes de uma sociedade moderna. 
Desta forma, o percurso teórico foi traçado por autores como Paulo Freire, Mário Kaplún, Martín Barbero, Orozco Gómez, Adilson Citelli, Ismar Soares, Roberto Aparici, Ângela Schaun, dentre outros que são referência nessa temática, ainda em fase efervescente. Ao longo dos últimos anos, o paradigma educomunicativo vem sendo legitimado na Europa, na América Latina, no Brasil e no mundo por vários pesquisadores. Assim, no exercício de aprofundar os fundamentos históricos da Educomunicação, alguns autores "comunicadores" se sobressaíram (SOARES, 2011).

No início do século XVI, o padre Jesuíta José de Anchieta, figura principal da literatura catequese, fez uso da "expressão estética" ao utilizar-se da poesia e do teatro como artefatos comunicacionais para evangelizar, catequizar e dialogar com seus interlocutores, propiciando que se expressassem (SOARES, 2011).

Outro ponto de destaque foi o filósofo da educação Célestin Freinet, que na primeira metade do século $X X$ foi um dos primeiros a implementar o uso das tecnologias como processo de mediação em sala de aula. O estudioso, também educador, destacou-se pela ousadia no ensino do francês, além de utilizar-se da tipografia em uma experiência educacional com crianças. A partir daí, o jornal escola ganhou amplitude e sua proposta foi considerada parte relevante do pensamento pedagógico, especialmente por contribuir com a "harmonização do meio, que permanece um fator decisivo da educação" (FREINET, 2004, p. 25), tais atividades ligadas à escrita e leitura permitem a promoção da criatividade, da participação, da livre expressão, da visão democrática e cidadã, além da promoção da práxis educomunicativa.

Conforme Soares (2011), Freinet defendeu a importância da integração dos educandos de acordo com o contexto em que viviam, e para atingir essa meta introduziu atividades desenvolvidas na prática da expressão livre por meio do jornal.

Assim como Freinet, o médico/educador Janusz Korczark, do ponto de vista educomunicativo, também destacou-se pelo pioneirismo de suas práticas envolvendo o jornal escola, considerando-o "um documento científico de grande valor" (KORCZARK, 1997, p. 332) que potencializa o processo de ensino-aprendizagem.

Ainda no século $X X$, montou um orfanato em Varsóvia para atender crianças em situação de abandono, tinha como intuito promover a justiça, a fraternidade, a igualdade de direitos e de obrigações, com isso utilizou o jornal escola como principal recurso para atingir tais objetivos (SOARES, 2011), proporcionando possibilidade de autoria e de engajamento no protagonismo em sala de aula. 
No âmbito educacional, o brasileiro Paulo Freire, propôs iniciativas relacionadas à educação popular e à comunicação sob uma vertente libertadora, priorizando as relações interpessoais. Além disso, no cenário latino-americano:

Freire entendia 0 diálogo como um elemento crucial para problematizar o conhecimento. Não era um diálogo complacente, um diálogo para o nada e sim uma modalidade que indagava os saberes mútuos e questionava o conhecimento preestabelecido. $O$ diálogo não é mera conversação nem conversa inconsciente, o diálogo é uma metodologia e uma filosofia (APARICI, 2014, p. 32-33).

Em seu legado, sustentou a perspectiva dialógica a favor da construção de uma pedagogia crítica, de modo que seus atores possam pensar, agir e dialogar criticamente. Em suas concepções também mencionou que:

enquanto na prática bancária da educação, antidialógica por essência, por isto, não comunicativa, o educador deposita no educando o conteúdo programático da educação, que ele mesmo elabora ou elaboram para ele, na prática problematizadora, dialógica por excelência, esse conteúdo, que jamais é depositado, se organiza e se constitui na visão do mundo dos educandos, em que se encontram seus temas geradores (FREIRE, 2005, p. 118-119).

O educador, no bojo de suas atribuições, não deve focar 0 processo de ensino-aprendizagem em uma abordagem bancária, reprodutora e "não comunicativa", na qual depositam-se conceitos, informações e conteúdos, mas precisa priorizar o desenvolvimento de práticas problematizadas e participativas.

Diante dessa interface, o referido autor já "empregava o termo educomunicador, nas décadas de 1980 e início de 1990, para identificar quem promovia a educação para a comunicação nas comunidades populares da América Latina" (MESSIAS, 2011, p. 155).

Em adição, Kaplún (1999) dá ênfase à Comunicação Educativa em uma perspectiva que foca a comunicação no âmbito educacional, que como campo de conhecimento não deveria ser vislumbrada como instrumento midiático e tecnológico apenas, mas constituir-se "componente pedagógico" interdisciplinar.

$\mathrm{Na}$ concepção dialógica de Freire, no Brasil, e a perspectiva educomunicativa de Kaplún na América Lativa contribuirám para vincular "os espaços do contexto sociocultural, da comunicação e da educação como relação, não como uma área que deva ter seu objeto disputado" (SOARES, 2011, p. 23), mas como um processo de interconexão destas áreas que permitem consolidar um território propício à ações educomunicativas. 
Neste percurso destacam-se também as Irmãs Salesianas, um grupo de religiosas que adotaram práticas da literatura popular e do teatro e com isso disseminaram

\begin{abstract}
a Educomunicação em mais de 1.200 obras de Dom Bosco, fundador de sua congregação religiosa que, ainda no século XIX, valorizava a comunicação interpessoal, impressa e teatral, garantindo que a educação deveria, substancialmente, partir da acolhida e da sensibilidade (SOARES, 2011, p. 65).
\end{abstract}

Acrescentando que, a proposta das Irmãs Salesianas, sob a ótica educomunicativa, visava promover a cultura comunicacional, educando a partir da espiritualidade e dos princípios do evangelho, esta condição está amparada na razão e religião. O espanhol Martín-Barbero, apresentou algumas possibilidades que poderiam interferir diretamente na maneira em que os receptores refletem os conteúdos das mídias e dos meios de comunicação, são elas: "a cotidianidade familiar, a temporalidade social e a competência cultural" (MARTÍN-BARBERO, 1997, p. 233).

Ainda sob esse aspecto educomunicativo, ele também abordou o conceito em torno dos ecossistemas comunicativos, ou seja, um ambiente dinâmico regado de relações consistentes entre comunicação e educação. De acordo com Martín-Barbero (1997), esses espaços se potencializam pela inserção das novas tecnologias, já para Soares (2011) tal relação dialógica não pode ser definida pelo uso da tecnologia e sim pela possibilidade de convívio entre seus atores.

De fato, além dos educadores e comunicadores citados, Ismar Soares também tem destaque nessa empreitada. Considerado um dos pioneiros da Educomunicação no Brasil, o professor atualmente é um dos mais atuantes no âmbito internacional. Sua concepção envolve a construção de um olhar sistematizado entre comunicação e educação, pois acredita que sua origem está entrelaçada num diálogo interdisciplinar, em uma perspectiva que pretende superar a visão fragmentada entre as duas áreas, considerando suas tradições, métodos e especificidades (SOARES, 2011).

De acordo com Soares (2011), todas essas personalidades têm em comum a abertura para compreender o outro; a promoção do diálogo na gestão de conflitos; a capacidade de contextualizar problemas e encontrar soluções de interesse coletivo; o poder da acolhida assegurando a livre adesão de seus interlocutores às propostas inferidas, cada qual com o uso de alguma tecnologia e/ou mídia a favor de seus ideais. E foi neste sentido que o percurso da educação para a comunicação ganhou sustentação no Brasil e na América Latina desde 1960, consolidando sua concepção e seus fundamentos até a presente data (SOARES, 2014). 
No entanto, para compreender sua concepção histórica é preciso retornar no tempo, rever suas raízes e compreender seus fundamentos, pois conforme o neologismo

\begin{abstract}
"Educomunicação" é, por natureza, polissêmico. Carregado de sentidos a ele atribuídos, ao longo das últimas décadas, pelos diferentes grupos que militaram no campo. Para alguns é simplesmente, sinônimo de educação diante dos meios, enquanto para outros designa um campo de intervenção social na interface entre comunicação e a educação (SOARES, 2014, p. 16).
\end{abstract}

Conforme Soares (2014), historicamente na década de 60 surgiram os primeiros programas vigentes no continente delineados para análise da produção cinematográfica, que abrangeu os cineclubes, colóquios e discussões mediadas por paróquias e escolas católicas. Na época, as mídias e os meios de comunicação eram alicerçadas em uma concepção alienante, tornando seus usuários sujeitos passivos. Contudo, essa fase foi marcada pelo início da formação da consciência crítica, além disso, teve destaque pela "popularização do trabalho educativo com o cinema" em 1968, ocorrido na cidade de Quito.

De acordo com tal perspectiva histórica da Educomunicação pode-se inferir que essa vertente começou a se fundamentar a partir de lutas e movimentos sociais entre jovens e adultos, adentrou outros espaços formativos e finalmente inserida nos sistemas educativos. No Brasil, por exemplo, grande maioria dos recursos midiáticos estavam focados apenas no entretenimento. Essa visão unilateral implodiu uma imensa quantidade de críticas, em especial à TV, em que o receptor apenas recebia a mensagem, desprovido de momentos de crítica e reflexão sobre a informação, pois mesmo sem a intenção explícita de educar, as mídias e os meios de comunicação são artefatos que podem contribuir para consolidar a educação em todos os seus âmbitos, seja no ambiente educacional formal, não-formal e/ou informal e desta forma, o sujeito, em uma perspectiva ativa, tem livre acesso à informação e ao conteúdo (SOARES, 2014).

$\mathrm{Na}$ década de 70, surgiu o movimento latino-americano com ênfase no "planejamento participativo", que se consolidou por intermédio de uma proposta de revisão da prática social e das teorias do desenvolvimento, destacando-se por influência em torno do conceito de Educomunicação e sua relação com a gestão de processos comunicativos (SOARES, 2014).

Destarte, a "sociedade da informação", em consonância com um progressivo avanço tecnológico, promoveu mudanças nos campos da comunicação e da educação. Assim, em meados de 1980 iniciaram os primeiros estudos sobre a maneira de interpretar as mídias no âmbito das políticas públicas e daí em diante passou a ter notoriedade no ambiente escolar. Em 1979 teve início uma ação articuladora da UNESCO (Organização das Nações Unidas para a Educação), a proposta teve como fio condutor a 
esfera das políticas públicas, o que constituiu um avanço teórico. Diante disso, a organização promoveu um encontro no México, que reuniu autoridades da educação e do planejamento dos países Latino-americanos e do Caribe. $O$ evento culminou na criação do "Projeto Principal de Educação na América Latina e Caribe", com a intenção de examinar problemas relacionados à educação no contexto do desenvolvimento geral da região (SOARES, 2014), focado em ações participativas, com o intuito de aproximar comunicação e educação.

Já em 1981 a UNESCO reuniu, em Quito, ministros da educação para apresentar ações relativas aos meios de comunicação nas escolas, com ênfase na educação crítica perante as mensagens massivas e que culminou nos Seminários de Educação para a Televisão, realizados em vários países Latino-americanos. Foram quatro encontros distintos: Santiago, Chile em 1985; Curitiba, Brasil em 1986; Buenos Aires, Argentina em 1988 e Las Vertientes no Chile em 1988 (SOARES, 2014). Destarte, em decorrência desses encontros e suas deliberações, a organização ampliou sua presença no continente e buscou apoiar novas ações.

Em conformidade com Soares (2014, p. 11) foi então que os educadores que atuavam sintonizados com o Projeto Principal centraram suas forças na "democratização das políticas de comunicação no continente, tendo como base a proposta de implantação de uma Nova Ordem Mundial da Informação e da Comunicação (NOMIC)".

Segundo o autor, este movimento possibilitou uma relação entre os "referenciais sobre o planejamento da ação participativa em projetos para o desenvolvimento e as práticas de negociação de sentidos reconhecidas pela teoria das mediações culturais" (SOARES, 2014, p. 11).

Contudo, em 1988, no último encontro ocorrido em Las Vertientes no Chile, o texto conclusivo trouxe inovações, em que a vertente que antes focava em “'educação para a televisão' ou para outra mídia em particular passou a ser designada em 'educação para comunicação', entendida como fenômeno essencialmente humano e político" (SOARES, 2014, p. 12).

Na Europa, Soares (2014, p. 13) afirma que a influência européia, revisada na América Latina por Jesus Martín-Barbero, deslocava o objeto de análise de muitos dos projetos da 'educação para a mídia' para uma "educação para os processos de mediações". Pode-se destacar que a década de 90 foi marcada pela influência dos estudos culturais. Essa concepção ocorreu em decorrência dos encontros promovidos pela UNESCO, sendo que o foco das ações era a compreensão dos processos comunicativos, fundamentais na produção da cultura na América Latina. Assim, conforme aponta:

a difusão dos estudos culturais, pela academia, acabou por facilitar a superação da bipolaridade (emissor $\mathrm{x}$ receptor) estabelecida pela 
corrente funcionalista, fortalecendo a perspectiva dialética que reconhece o papel ativo do consumidor de mídias enquanto um construtor de sentidos. Foi possível, desta forma, passar de uma teoria fundada no tecnicismo, centrada nos meios, para uma reflexão articuladora das práticas de comunicação, entendidas como fluxos culturais, focada no espaço das crenças, costumes, sonhos, medos 0 que, enfim, configura a cultura do cotidiano (SOARES, 2014, p. 13).

Outrossim, a vertente dialética e cultural, pautada nas práticas de comunicação, trouxe avanços para a interface entre comunicação e educação na América Latina. De acordo com Soares (2014), no período entre 1990 e 2000, houve uma crescente abertura internacional entre pesquisadores, estudos, projetos e eventos, no sentido de relacionar esses campos do conhecimento. O êxito de tais parcerias entre os Hemisférios Norte e Sul resultaram em uma fase efervescente para a Educomunicação.

No período de 1995, na Espanha, Roberto Aparici, em parceria com educadores do Programa "Pé de Exame" da Galáxia deram início a uma série de eventos internacionais que buscaram fortalecer, solidificar e legitimar a "Média Education" em todo o mundo, além de promover a aproximação entre os hemisférios Norte e Sul e dos propósitos educativos a serviço de uma análise crítica da mídia (APARICI, 2014).

Portanto, essas características demandam do "educomunicador" que seja um profissional reflexivo, criativo, pesquisador e investigativo, capaz de promover a democracia, apoiar a liberdade de expressão, integrar dinâmicas formativas, desenvolver uma nova postura social, humana e cidadã, além de agir coletivamente em Ecossistemas Comunicativos (APARICI, 2014).

Nesse caminho, mídia e educação são processos que motivam a participação ativa do sujeito, de modo que dominem o sistema educativo, construindo e compartilhando conhecimentos a partir do potencial inovador das tecnologias. A comunicação/educação é um processo de interação social que pretende transformar a comunidade educativa num ecossistema comunicativo, aberto, dialógico e participativo, enquanto a Educomunicação constitui-se área do conhecimento que a partir da interface entre comunicação e educação busca promover o protagonismo e a produção colaborativa de seus atores por meio de práticas dialógicas, além de proporcionar reflexões permanentes dos recursos e das interações comunicativas que perpassam todo ambiente educacional (SOARES, 2014).

No Brasil, os primeiros estudos nessa área foram realizados pelo NCE-USP criado em 1996 por meio da formação de um grupo de docentes que apresentavam interesses em comum, os quais ganharam destaque ao desenvolver uma pesquisa estruturada em conjunto com 178 especialistas em 12 países da América Latina e Penísula lbérica. O estudo ocorreu entre 1997 e 1999, quando foi possível identificar "um espaço de produção de sentidos decorrente do reconhecimento da essencialidade do direito à comunicação em 
todos os espaços da vida social, incluindo o educacional e o próprio espaço comunicacional" (SOARES, 2014, p. 16).

Os profissionais centraram seus esforços em uma investigação articuladora e estratégica focada na interconexão entre comunicação e educação. Todos tinham como propósito compreender o pensamento dos coordenadores de projetos dessa área de estudos e delinear o perfil dos profissionais atuantes nessa mesma vertente (SOARES, 2011).

A pesquisa foi considerada $o$ ponto de partida para a compreensão da Educomunicação como um "novo campo de intervenção social", apontando a seguinte definição para a Educomunicação: conjunto de ações voltadas ao planejamento e implementação de práticas destinadas a criar e desenvolver ecossistemas comunicativos abertos e criativos em espaços educativos, garantindo, desta forma, crescentes possibilidades de expressão a todos os membros das comunidades educativas (SOARES, 2011, p. 36).

A partir desse estudo, o conceito passou a ter abrangência internacional. Desde então, os termos relacionados à Educomunicação tornaram-se recorrentes no Brasil e toda a América Latina e por isso aponta que:

\begin{abstract}
Educomunicação pressupõe a autonomia epistemológica de sua ação, uma vez que sua sustentação não exatamente nos parâmetros da educação (de suas filosofias ou didáticas), ou mesmo da comunicação (de suas teorias e práticas), mas na interface entre ambas (o mundo que se revela no encontro dos dois campos tradicionais (SOARES, 2014, p. 17).
\end{abstract}

Ao longo dos tempos, outros termos foram se consolidando e têm enfatizado a prática da educação para a comunicação, tais como: recepção crítica da mídia, pedagogia da comunicação, educação para a televisão, pedagogia da imagem, didática dos meios audiovisuais, educação para a comunicação, educação midiática, dentre outras nomenclaturas (APARICI, 2014).

Diante da convergência entre as formas de mediação e difusão de saberes entre as duas áreas, a Educomunicação é compreendida como referência teórica e metodológica que propõe ao educador construir um perfil educomunicador. Assim, as universidades estão diante de um desafio: formar profissionais para atuar na "era da informação", os quais devem estar preparados para "trabalhar em equipe, para se adaptar às condições de mudança e para identificar e resolver problemas" (SOARES, 2011, p. 115).

Para atuar na vertente educomunicativa Soares (2011) destaca a importância do profissional promover o pleno exercício da cidadania, o direito ao protagonismo juvenil, a troca de saberes, o diálogo e a livre expressão nos 
espaços educacionais, além das possibilidades de construção do conhecimento aliado às inovações tecnológicas.

Desenvolvendo, assim, competências e habilidades para planejar, aplicar e avaliar o percurso educacional de maneira sistematizada com os propósitos do processo de ensino-aprendizagem. Pode-se inferir que tais ações demandam a promoção de metodologias delineadas por caminhos e possibilidades educomunicativas, além de propostas práticas colaborativas e favorecidas pelo diálogo entre a comunicação e a educação, conforme veremos na sequência.

\subsection{As perspectivas trilhadas e as novas possibilidades da Educomunicação}

De fato, a comunicação é um processo que ampara as relações humanas, culturais e sociais, sendo que essa interlocução se dá pelo acesso aos meios de informação, aos significados, à interpretação e ao entendimento das mensagens. Ao tratar dessa vertente, Kenski (2008, p. 436) defende que "o ato comunicativo com fins educacionais realiza-se na ação precisa que lhe dá sentido: o diálogo, a troca e a convergência comunicativa, a parceria e as múltiplas conexões entre as pessoas", interligadas pelo desejo de conviver, ensinar e aprender coletivamente.

Neste sentido, Soares (2014, p. 21) aponta que "da comunicação, importa à Educomunicação a criatividade e o potencial inovador trazido para a produção cultural pelas tecnologias da informação". Com isso, a comunicação torna-se um dos focos do fazer pedagógico e esse olhar inclui também a perspectiva da recepção, diálogo, interpretação, intercomunicação e mudança de atitude sob a ótica das concepções educacionais.

Diante desse norte, a educação é conceituada por Libâneo (2013, p. 49) como "instância de promoção da autorreflexão e do desenvolvimento das capacidades intelectuais e operativas, necessárias à formação da razão crítica", ou seja, é dialógica e tem passado por um amplo processo de transformação, "um fenômeno plurifacetado, ocorrendo em muitos lugares, institucionalizado ou não, sob várias modalidades" (LIBÂNEO, 2002, p. 26) que constitui-se em uma junção de atos dinâmicos que pretendem envolver os diversos atores do processo educacional na perspectiva do desenvolvimento humano, essa vertente inclui educadores, educandos, gestores e toda comunidade escolar.

Como esclarece Soares (2014, p. 21) que "do campo da educação, importa à Educomunicação os conhecimentos produzidos a partir da área da sociologia da educação, que trabalha fundamentalmente com as teorias da aprendizagem social”, daí pode-se inferir que a sua relação flexível 
com as diferentes áreas do conhecimento contribui para consolidar o diálogo entre vários campos do saber.

Soares (2014) afirma que a instituição escolar constitui-se espaço permanente de inovação, consolidada pela perspectiva de formação de sujeitos participativos, críticos e reflexivos, com voz ativa e potencialmente capazes de assumir o protagonismo juvenil nos diferentes espaços: na escola, na comunidade e no contexto social onde atuam. A fim de consolidar esse debate, ao analisar os destaques e termos recorrentes neste estudo, segue a representação visual que culminou no conceito de Educomunicação. A imagem fica assim representada:

Figura 1 - Palavras que inspiram a Educominucação no âmbito escolar.

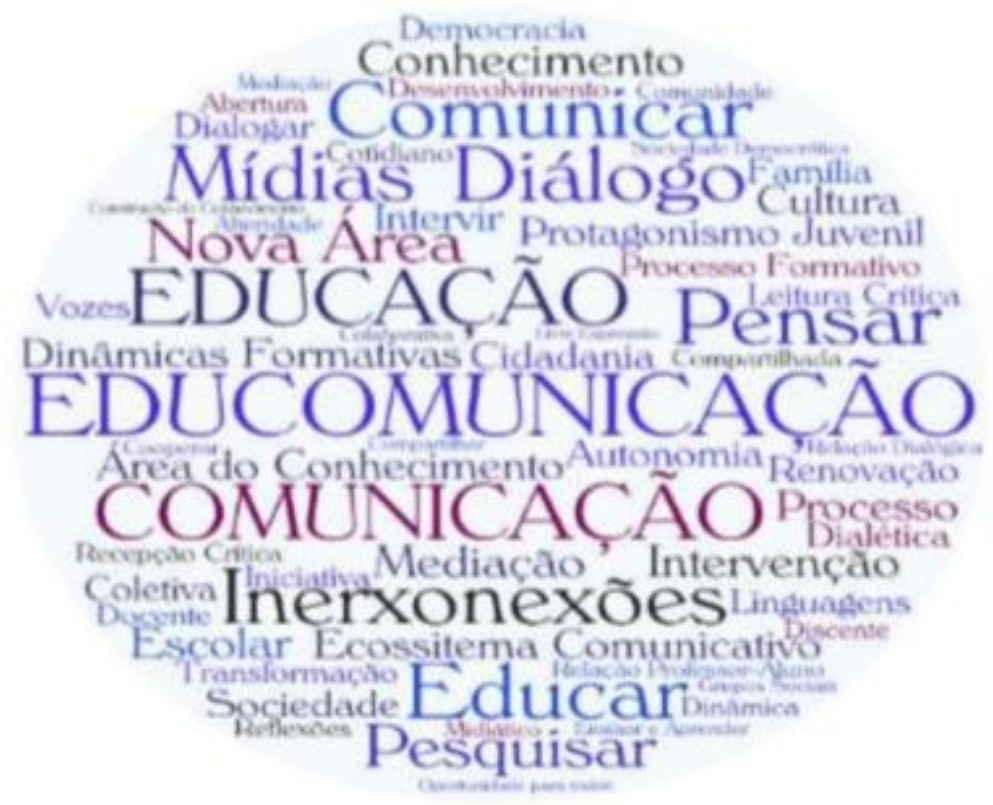

Fonte: Baseado nos pensamento de Soares (2014, p. 8).

A partir desse círculo de palavras pode-se inferir que a Educomunicação é uma área do conhecimento consolidada pela interconexão entre a Comunicação e a Educação, que busca estimular o diálogo e a reflexão, em outras palavras, é um campo de mediação que constitui-se dinâmico e dialético, pois à medida que impulsiona o protagonismo juvenil, também promove uma postura dialógica entre 0 ensinar $e \quad 0$ aprender coletivamente, fortalece a capacidade de expressão e solidifica as bases das relações interpessoais, democratizando o conhecimento por meio dos avanços tecnológicos e suas possibilidades educacionais e comunicacionais. Contribui para fomentar espaços formativos propícios a construir planos de aprendizagens flexíveis, além de promover a gestão de processos educativos 
por meio de projetos e artefatos tecnológicos, que possibilitem dialogicidade e livre expressão do jovem e do coletivo (SOARES, 2014).

O alicerce dessas práticas requer constante renovação. Para atuar no âmbito da Educomunicação, Shaun (2002, p. 97) diz que "a formação de um profissional com habilidades para atuar no contexto da inter-relação Comunicação/Educação deve contemplar o aporte de uma consciência ética e pragmática voltada para as transformações da sociedade" corroborando com essa perspectiva formativa, Batista (2012) em tese "Um diálogo entre Comunicação e Educação: a Formação Inicial de Professores em Sociedades Midiáticas" menciona a necessidade de assumir:

a Educomunicação como um dos eixos dos cursos de formação inicial de professores, preparando os atuais educandos e futuros docentes para um trabalho articulado entre educação e comunicação, que favoreça a promoção de diálogos críticos entre o trabalho mais propriamente didático e pedagógico e os desafios que nos trazem as transformações tecnológicas e culturais das sociedades contemporâneas (BATISTA, 2012, p. 22).

Soares (2011, p. 20) destaca que "torna-se necessário, pois, que sejam adotadas políticas que facilitem a formação deste novo docenteeducomunicador".nAs possibilidades existem, no entanto, evidencia-se a importância de ampliar e desenvolver em todo o espaço educacional uma estrutura curricular e um PPP consistente, que proporcione maior reflexão sobre a formação, a prática e os saberes inerentes ao Educomunicador, de modo que todos estejam envolvidos com a proposta e suas implicações.

Contudo, para impulsionar esse princípio que busca promover uma força transformadora entre os jovens, é fundamental uma estruturação que esteja contemplada no currículo da escola, no PPP e bases legais que regem a sociedade no que concerne à interface entre comunicação e educação.

Consequentemente, o Educomunicador sente-se integrante de uma teia colaborativa de conhecimentos, capaz de construir e difundir saberes. Depara-se com o desafio de utilizar a comunicação e todo aparato tecnológico como ferramentas complementares às suas práticas. Em suas atribuições, deve elaborar uma intervenção educacional de forma organizada e dialógica, pois trabalhar em equipe requer (re)avaliar as formas de colaboração, confrontar as opiniões, estimular a interação entre os diferentes atores e mediar relações interpessoais que resultem em uma prática social transformadora (SOARES, 2014).

Partindo dessa perspectiva de atuação educomunicativa será possível ensinar e aprender por meio de uma consciência coletiva, subsidiar práticas formativas e colaborativas, resgatar o interesse da turma, estimular a 
(re)construção do conhecimento, ampliar o processo de descoberta, difundir saberes construídos nos mais diversos ecossistemas educacionais, promover o uso de diferentes recursos tecnológicos, propor práticas cidadãs e democráticas que favoreçam a criticidade diante dos fatores sociais e dos meios de comunicação, transformando o ambiente escolar num espaço compartilhado e propício a novas descobertas.

\section{CONSIDERAÇÕES FINAIS}

Assim, no intuito de implementar a prática formativa na construção de saberes para atuar na/e para a Educomunicação, é fundamental que 0 educomunicador esteja comprometido em aprofundar seus conhecimentos teóricos metodológicos, participando ativamente de contextos de formação continuada, seja por meio de palestras, oficinas, congressos, seminários, ou através de cursos extensão, aperfeiçoamento ou pósgraduação.

É possível perceber que o campo Educomunicação está em processo de expansão no Brasil e demanda que o educomunicador esteja em permanente processo de formação para que sinta-se preparado para superar os desafios oriundos desse cenário.

A partir da perspectiva transdisciplinar, a Educomunicação busca transcender o sujeito, as práticas sociais e a relação comunicação/educação, não limitando sua atuação somente a esses campos. A vertente da interdiscursividade focaliza suas concepções no diálogo com outros discursos, sugerindo que a educação mantenha uma relação de interface com a comunicação e outras áreas de intervenção social, à medida que vai consolidando sua própria especificidade educomunicativa.

O profissional que acredita nessa concepção de trabalho precisa comprometer-se com a construção de um ambiente escolar que integre dinâmicas formativas e processos de aprendizagens. Desta forma, estará apto a atuar no sentido de construir e consolidar ecossistemas comunicativos coletivamente, delineando ações sob as vertentes: inclusivas, sem excluir membros; democráticas, promovendo e reconhecendo igualdade entre seus atores; midiáticas, promovendo mediações impulsionadas por recursos da informação; criativas, incluindo todas as formas de expressão cultural local.

Esse entendimento, que adentra o exercício da docência educomunicativa, aponta para a necessidade das instituições, nas esferas federais, estaduais e municipais, buscarem um engajamento pautado em delinear políticas públicas e diretrizes educativas que possam fomentar a 
formação desses profissionais atendendo a essa nova demanda e não deixando tal incumbência exclusivamente ao educomunicador.

\section{REFERÊNCIAS}

APARICI, R. (org). Educomunicação: para além do 2.0. São Paulo: Paulinas, 2014.

BATISTA, S. Um diálogo entre comunicação e educação: a formação inicial de professores em sociedades midiáticas. Tese. Universidade de São Paulo. São Paulo. 2012.

CASTELLS, M. A sociedade em rede. São Paulo: Paz e Terra, 1999.

CITELI, A. Comunicação e Educação: a linguagem em movimento. São Paulo: Senac, 2000.

FÍGARO, R. Comunicação/educação: campo de ressignificação das tecnologias de comunicação. In: Comunicação e Educação, São Paulo, CCA/ECA/USP, ano XV, n. 3, p. 7-15, set./dez. 2010.

FREIRE, P. Extensão ou comunicação? Coleção O mundo hoje, v. 24, 10 ed., São Paulo: Paz e Terra, 1988.

. Pedagogia do Oprimido. Rio de Janeiro: Paz e Terra, 42 ed.

2005.

FREINET, C. Pedagogia do Bom Senso. 7 ed. São Paulo: Martins Fontes, 2004.

GADOTTI. M. O jornal na escola e a formação de leitores. Brasília: Liber Livro, 2007.

GUTIÉRREZ; F. La mediación pedagógica y la tecnologia educativa. In: Tecnologia Educacional, v. 25, p.132-133. Rio de Janeiro, set/dez. 1996.

KAPLÚN, M. Processos Educativos e Canais de Comunicação. Revista Comunicação \& Educação. São Paulo, Editora Moderna, v. 14, jan/abr., 1999.

KENSKI, V. Educação e comunicação: interconexões e convergências. Educação \& Sociedade, v. 29, n. 104, p. 647-665, out/2008.

KOCH, I. V. A interação pela linguagem. 8 ed. São Paulo: Contexto, 2003. 
KORCZAK, J. Como amar uma criança. Rio de Janeiro: Paz e Terra, 1997.

LAKATOS, E.; MARCONI, M. Metodologia do trabalho científico. 5 ed. São Paulo: Atlas, 2001.

LIBÂNEO, J. Democratização da escola pública: a pedagogia crítico-social dos conteúdos. São Paulo: Loyola, 1990.

. Pedagogia e pedagogos, para quê? 6 ed. São Paulo: Cortez,

2002.

MARTÍN-BARBERO, J. Dos meios às mediações: comunicação, cultura e hegemonia. Trad. Ronald Polito, Sérgio Alcides. Rio: UFRJ, 1997.

MESSIAS, C. Duas décadas de Educomunicação: da crítica ao espetáculo. 2011. 240 f. Dissertação. Escola de Comunicações e Artes. Universidade de São Paulo, São Paulo, 2011.

SCHAUN, A. Educomunicação: reflexões e princípios. Rio de Janeiro: Mauad, 2002.

SOARES, I. Comunicação/educação: a emergência de um novo campo e o perfil de seus profissionais. Revista Brasileira de Comunicação, Arte e Educação. Brasília, DF, n. 2, v. 1, p. 05-74, jan./mar. 1999.

. Educomunicação: o conceito, o profissional, a aplicação. 2 ed. São Paulo, SP. Paulinas, 2011.

. Educomunicação: um campo de mediações. In: CITELLI, A. e COSTA, M. (org.). Educomunicação: construindo uma nova área do conhecimento. São Paulo: Paulinas, 2011.

Introdução à edição brasileira. In: APARICI, R. Educomunicação: para além 2.0. São Paulo: Paulinas, 2014.

VOLPI, M; PALAZZO, L. (org). Mudando sua escola, mudando sua comunidade, melhorando o mundo! Brasília: Unicef, 2010. 


\title{
SEUS FILHOS NÃO PODEM APRENDER IGUAL A VOCÊ: Como a psicologia científica quebra mitos da aprendizagem e nos ajuda a moldar a escola do futuro
}

\author{
MARTINS, Murillo E. Ravagnani S. \\ Graduando em Direito - Faculdade de Direito de Franca \\ profissional.murillo@gmail.com \\ TOFFANO, Marcelo \\ Doutor em Direito - Faculdade de Direito de Franca \\ prof.toffano@gmail.com
}

\section{INTRODUÇÃO}

A educação formal sempre foi adequada aos padrões políticos e econômicos de sua época. No final do século XIX, houve uma separação impulsionada pela política de fragmentação do processo de produção industrial. Naquela época, era necessário que educação tivesse um viés técnico, ou seja, que as pessoas aprendessem profissões que exigissem um mínimo de conhecimento, como datilografar ou operar máquinas no banco. A escola iluminista surge desta maneira, voltando a educação para a produção de trabalhadores que se adequem às profissões. Na visão de Adam Smith, por exemplo, uma nação rica é uma nação capaz de gerar trabalho, e isso implica em alguns princípios: Desigualdade social (pois é necessário que tenha aquele que emprega e aquele que é empregado) e o papel do Estado, que é proteger os riscos dos pobres (evitando que uma nova Revolução Francesa aconteça, o que levaria à perda na capacidade de gerar trabalho); as escolas surgem baseadas neste conceito: Não se estudava para saber, se estudava para ter um ofício, e assim gerar trabalho, mas com pouco conhecimento.

Assim como as fábricas, a educação formal funcionou desde então como um processo industrial, bem separada, o menos complexa possível, focada na quantidade, e não na qualidade, e, principalmente, sem a preocupação se o métodos utilizados até então eram, de fato, adequados. Nesta "educação sistêmica", os métodos que entendíamos serem ideais inclusive se assemelhavam com os processos industriais: Memorização massiva, rigidez nos espaços, hierarquização do ensino, etc. Junto com isso, começaram a ser construídos ideais de como seriam as melhores maneiras de se aprender, como por exemplo conceitos de que a memória armazenaria informações como um computador, ou de que estudar num lugar tranquilo é sempre melhor, ou até de que estudar antes das provas seria inútil. Esses e outros mitos perpetuam até hoje, principalmente entre a sabedoria popular, porém, experimentos científicos no campo da Psicologia da Aprendizagem 
quebram alguns destes conceitos através de experimentos e teorias construídas através do tempo, desde de Thorndike a Bjork, que aqui estarão conectadas com as bases biológicas do funcionamento da nossa memória.

As fontes usadas neste artigo são, principalmente, citadas no livro de Benedict Carey: "Como Aprendemos: A surpreendente verdade sobre quando, como e por que o aprendizado acontece" onde o autor reúne as pesquisas mais relevantes no campo do aprendizado, e traça um paralelo do nosso passado da educação até o estado atual da ciência, tentando identificar nossas bases biológicas, cognitivas e comportamentais de como aprendemos.

Uma vez que tenhamos compreendidos a maneira ideal de se aprender, olharemos para o estado atual da nossa educação formal, e tentaremos conceber como deveria ser a educação da próxima geração, não só baseado nas mais apropriadas teorias da Psicologia, mas baseados também nas mudanças da sociedade do trabalho, observando as habilidades que o futuro nos proporcionará, uma vez que sabemos que o que aprendemos na escola hoje não é exatamente apropriado para as "skills" futuras que serão exigidas. É a realização da maneira ideal de se aprender, com o conteúdo do futuro a se aprender, o que, se visto com uma ótica ampla, mostra que há muito o que mudar no campo da educação. Existem ocupações que cairão em desuso e serviços que serão automatizados, além de novas profissões que surgirão e, com as modernas dinâmicas do mercado de trabalho, uma provável alteração na maneira que formamos alunos. Porém, apesar de toda essas grandes mudanças dinâmicas, ainda temos um futuro menos revolucionário do que a maioria de outras pesquisas indicam, mostrando que profissões e habilidades que imaginamos que desapareceriam, na realidade tendem a ser mais valorizadas até 2030 (ano máximo de previsão do estudo).

Tendo em vista todo o respaldo científico tanto das pesquisas que desvendam nosso cérebro, quanto as que prevêem o futuro das habilidades, uma certeza surge como alarmante e inquestionável: A de que nossos filhos não podem aprender como nós aprendemos.

\section{COMO APRENDEMOS}

2.1 A Biologia da Memória

A ciência da aprendizagem é um estudo do funcionamento do músculo mental (o cérebro vivo), de como ele gerencia o fluxo contínuo de visões, sons e aromas da vida diária. O cérebro é formado por neurônios, que se ligam a vários outros neurônios, formando uma tempestade elétrica, com capacidade de "armazenamento" de um milhão de gigabytes. Para uma melhor 
compreensão de como funciona esta complexa "máquina" de pensamentos em relação a memória, é essencial citar e explicar três elementos que estão no nosso cérebro e que compõem o "trajeto das lembranças": O Córtex Entorrinal, onde primeiro se chega a informação, e sua função é filtrar as informações recebidas. Em seguida, o Hipocampo faz o trabalho do início da formação da memória, e por fim o Neocórtex, a camada mais fina e externa do cérebro, também a última a aparecer na nossa história evolutiva, são onde as memórias ficam armazenadas. Toda informação consciente faz este caminho.

Figura 2. Cérebro humano, onde se destacam as partes essenciais da formação da memória.

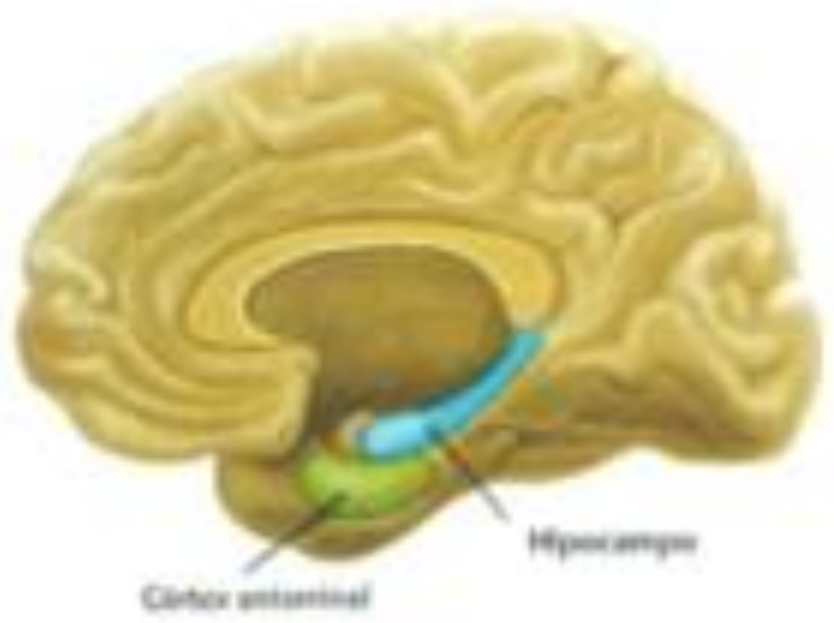

Uma vez que compreendamos que somos formados de neurônios, fica mais fácil o entendimento de que uma lembrança nada mais é do que um padrão, que é gravado por uma rede neural. Cada neurônio se liga a uma célula, formando uma ligação chamada de sinapse. Várias sinapses ao mesmo tempo, formando um padrão, é chamado de rede neural. A cada acontecimento específico, umas dessas é criada, que se intensifica e se torna mais veloz com o repetido uso da mesma lembrança. Estas redes neurais estão em constante mudança. Isso significa dizer que nossos neurônios morrem e nascem, e neste processo, detalhes são deturpadas ou simplesmente apagadas (por isso nossa memória não é tão confiável, e existem vieses de formação de falsas memórias).

Até o século XX, acreditávamos que a memória estava armazenada no cérebro de forma distribuída (espalhada aleatoriamente por todo o cérebro), até porque os neurônios são iguais em todo o órgão. Até então, nenhuma área parecia essencial para a formação de uma memória. Em 1940, Karl Lashley demonstrou que ratos que sofriam danos no cérebro não se 
abalavam na memória. Ora, se a teoria do século $X X$ fosse verdade, haveria algum dano; Karl concluiu, portanto, que qualquer área do cérebro era capaz de sustentar a memória, que compensava a perda da área lesionada. Em 1950, descobriu-se que os neurônios-bebês (recém formados) vão para uma parte pré-programada do cérebro, com uma função definida, o que colocou em xeque a teoria de "neurônios intercambiáveis".

Anos depois, uma pesquisadora chamada Brenda Milner descobriu através de experimentos que a remoção de determinadas partes do cérebro influenciava diretamente a memória. No caso de um famoso paciente chamado Molaison, foi removido o hipocampo, portanto, o paciente não mais conseguia lembrar de novos nomes, rostos, fatos ou experiências; seu cérebro registrava as informações, mas não conseguia retê-los. Entendemos, neste momento, que as partes retiradas de Molaison fazia com que ele não gravasse essas informações, mas em relação a memórias motoras (memória física), seu cérebro não foi comprometido. Milner, portanto, chegaria a conclusão: Existem ao menos dois sistemas no cérebro para lidar com a memória; Um consciente, e um inconsciente. A consciente é a "intelectual", como informações que se pode anotar, na aula de história ou matemática. A inconsciente diz respeito às funções motoras (físicas), que se formam sem que tenhamos que pensar muito sobre elas. Morria aí, portanto, a teoria da memória distribuída no cérebro. Descobriríamos que existem funções específicas para a formação da memória. Ainda com o paciente Molaison, encontrou-se mais tarde que suas memórias essenciais estavam vivas. Lembranças de antes da cirurgia, basicamente. Há um padrão: Pessoas com lesões no hipocampo não conseguem formar novas memórias, mas mantém as antigas. Isso significa dizer que uma vez formada as memórias, elas são armazenadas em outro lugar. Esse lugar seria 0 Neocórtex, a fina camada exterior do cérebro. Somente o neocórtex é capaz de resgatar as narrativas; memórias mais complexas, ou lembrar das sensações de cheiro, um som, um peso. A memória reside por todo o neocórtex.

Por último, é importante notarmos que nosso próprio cérebro cria uma "narrativa" para cada acontecimento, favorecendo uma melhor memorização pelo contexto. A essa memória específica é dada o nome de Memória Episódica ou Autobiográfica, que se trata de uma lembrança de si mesmo, com a característica de ser uma história com estrutura narrativa, da qual a lembrança é formada pelo ambiente, sensações, texturas sensoriais, sentimentos. Casos que demonstram muito bem a necessidade desta "estrutura narrativa" são as cirurgias "Split Brain": Ao cortar a conexão entre o hemisfério direito e esquerdo, percebemos bem a função de cada parte: $O$ esquerdo é o "intelectual", que possui a linguagem. O direito é o "artista", que contém as partes visuais. Quando mostrado a um paciente que fez a cirurgia do Split Brain um pé de galinha para o lado esquerdo (linguagem), e neve para o lado direito (visual), e pediu-se para associar essas duas imagens com outras 
duas figuras: Uma pá e uma galinha, e em seguida pediu-se para explicar-se o porquê desta associação, quando revelou-se algo interessante: Quanto ao pé de galinha, o paciente havia palavras para descrever, justificando corretamente; mas quando perguntado sobre a neve (da qual também associou corretamente: a pá com a neve), não sabia responder. A resposta, disse, foi instintiva, sem qualquer motivo lógico (claro, pois apenas o cérebro visual o viu, e não a linguística). A questão é: Por que ele escolheu a pá? Bem, isso aconteceu porque, ao buscar no hemisfério esquerdo uma imagem coerente (o lado esquerdo não viu a neve), apenas encontrou a imagem da galinha. A partir daí, entrou em ação um módulo no nosso lado esquerdo que é o responsável por armazenar as informações e dar a elas uma narrativa para a percepção consciente: O "Módulo Intérprete"; o criador de histórias.

O módulo se faz constantemente a pergunta "O que acabou de acontecer?", ou seja, uma estímulo interno. Mas há também o estímulo externo, quando tentamos nos lembrar de informações dentro do nosso cérebro. A cada tentativa de lembrança, a cada vez que "rebobinamos a fita", um novo detalhe na memória surge. Um cheiro, um som do momento, uma sensação específica. O cérebro não armazena fatos como uma memória de computador; a cada vez que você abra uma "pasta", é adicionado, entrelaçado e sobreposto uma nova lembrança. Nada é perdido, apenas modificado. O uso da memória altera a memória.

\subsection{A Importância do Esquecimento}

Temos a tendência a pensar no fato do esquecimento como necessariamente prejudicial, como uma falha do cérebro. Tratamos a nãolembrança como sendo algo a se evitar a todo custo, e por isso o identificamos como um inimigo do aprendizado. Mas, na realidade, é praticamente o oposto.

Esquecer é o grande "anti-spam" do cérebro, de forma que atua como um filtro para as informações importantes. Se não houvesse o esquecimento, nós nunca teríamos a paz de não pensar mais em situações emocionalmente graves que passamos, ou em informações inúteis. Acabamos nos envolvendo com esse tipo de esquecimento direcionado o tempo todo, sem percebermos. Se estivermos imersos num campo de conhecimento específico, é comum esquecermos palavras corriqueiras como "garfo" ou "mesa". É o sistema de bloqueios de informações do cérebro. Como William James observou: "Se nos lembrássemos de tudo, na maioria das vezes, seria tão danoso quanto se não nos lembrássemos de nada". Por isso, é importante notar, como salienta Carey: "A nitidez da lembrança depende da força do esquecimento". 
Outro grande benefício do esquecimento nada tem a ver com a propriedade ativa da filtragem. Aquele esquecimento normal, do dia a dia, também é útil para o aprendizado subsequente. Aqui, há o primeiro mito a ser quebrado: O cérebro não é como um músculo. Isso significa dizer que "treinar seu cérebro" não te ajuda a memorizar maiores informações, em atividades como palavras-cruzadas ou exercício de matemática. Neste sentido, sua memória não é "melhorada" e nada tem a ver com outro músculo qualquer. Apesar disso, é possível fazermos uma comparação entre ambos, uma vez que tal "esquecimento normal" pode ser pensado como uma propriedade do desenvolvimento muscular, como alguma "pane" que deve ocorrer para que possamos reforçar o aprendizado quando revisitamos um assunto. Sem um pouco de esquecimento, não se extrai qualquer benefício de um estudo mais aprofundado. É o que permite a construção do aprendizado, como um músculo exercitado.

Hermann Ebbinghaus foi o pesquisador que criou a famosa "Curva do Esquecimento", um gráfico de perda de memória ao longo do tempo, que representa a taxa à qual informações recém-aprendidas desaparecem da memória. Ela, sem geral, tem esta aparência:

Figura 2 - Exemplo didático da Curva de Esquecimento de Hermann Ebbinghaus.

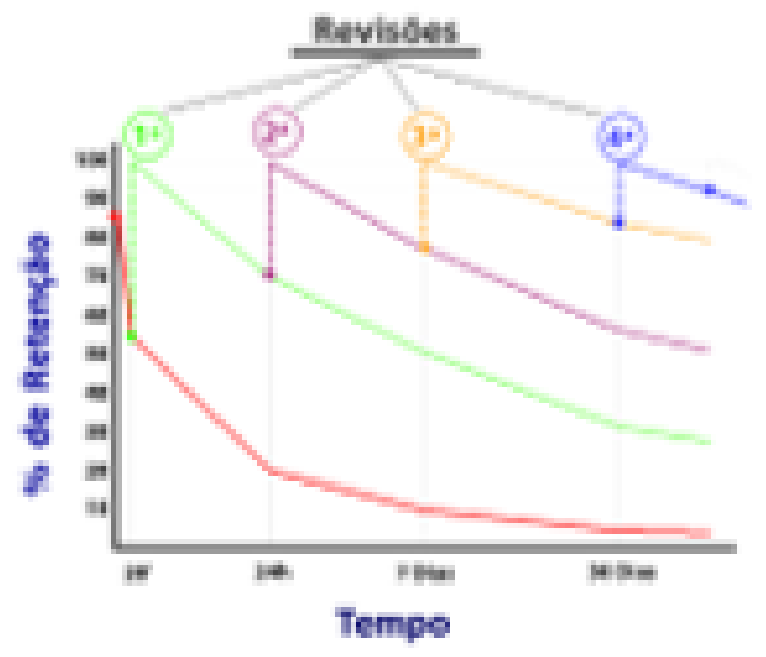

O alemão, para chegar a este resultado, produziu pesquisa criando mais de duas mil sílabas sem sentido (RUR, HAL, MEK, BES, etc.) e memorizou-as durante horas, por vários dias. Ele se testava em diferentes intervalos: Vinte minutos depois de estudar, uma dia, sete dias ou um mês depois. Ao analisar os resultados, descobriu que quanto mais praticava, mais aumentava sua pontuação, e seu índice de esquecimento diminuía. Aos analisar os dados, encontrou o padrão mostrado acima. Era, em sua época, o 
primeiro trabalho com modelo estatístico bem estruturado que dizia respeito às memórias.

No início dos anos 1900 o pesquisador Phillip Ballard deu continuidade no interesse da ciência na memória humana. Reuniu um grupo de estudantes o os aplicou testes de memória. Dois dias depois do primeiro teste, veio outro. Para a surpresa do pesquisador, os alunos se saíram melhor desta vez, em média 10\%. Ora, esta evolução parecia estranha, principalmente na ótica da Curva de Esquecimento. Sendo assim, Ballard aplicou centenas de testes adicionais, com mais de 10 mil pessoas ao longos dos próximos anos, e os resultados continuavam os mesmos: Observou-se que a memória melhorava após dois ou três dias, mesmo sem estudo prévio, e que o esquecimento só começa após o quarto dia, mostrando que não só tendemos a esquecer o que já lembramos, como lembramos o que já esquecemos. Nos testes de Ebbinghaus, ele usou palavras inventadas e sem sentido. No nosso cérebro, não possuímos lugar o referências para essas informações. O poder de associação se perde neste caso, portanto, sustenta essas informações por muito menos tempo.

O esquecimento não é apenas um processo passivo de desaparecimento, mas também um processo ativo de filtragem. Este processo ativo irá filtrar as sílabas sem sentido, porque inevitavelmente serão informações inúteis, para o cérebro.

Anos depois, temos hoje o que chamamos de "Nova Teoria do Desuso", que também pode ser interpretada como "Teoria do Esquecer para Aprender". Esquecer boa parte do que acabamos de aprender, sobretudo no que se refere a um assunto novo, não é necessariamente um indicador de preguiça, déficit de atenção ou de uma falha de caráter. Pelo contrário, é um sinal de que o cérebro está funcionando como deveria.

Ela se baseia em dois princípios: O primeiro diz que toda lembrança possui duas forças, de armazenamento e de recuperação. A primeira é uma forma de medir até que ponto algo foi aprendido; reforçada com o estudo, e de forma mais acentuada com o uso, como por exemplo a tabuada. É uma força que pode aumentar, mas nunca diminui. Já o segundo está relacionada com a velocidade com o qual o nome de uma pessoa vem à mente; O armazenamento, com o seu grau de familiaridade com a pessoa. Ex. Seus pais, armazenamento alto, recuperação rápida. $O$ nome da sua professora do primeiro ano não vem de pronto à mente (recuperação baixa), mas ao ver, você tem certeza que é ela (armazenamento alto). A cada vez que se lembra do rosto e do nome, você reforça ambas as forças.

Quanto mais esforço precisamos fazer para recuperar a memória, maior o pico subsequente do poder de recuperação e armazenamento. Os Bjork chamam esse princípio de dificuldade desejável, ou seja, a dificuldade da lembrança leva ao fortalecimento da mesma. O cérebro desenvolver esse 
sistema por um bom motivo: Nos primórdios dos hominídeos nômades, o cérebro continuamente renovava seu mapa mental para se adaptar às mudanças climáticas, topografia e predadores. A força da recuperação evoluiu e atualizava as informações rapidamente. Há uma história evolutiva da memória.

Portanto, o esquecimento é essencial para o aprendizado de novas habilidades e para a preservação e reaquisição de antigas. Se quiseres gravar uma informação importante, se permita e esquecer e alterar esta memória - esta é a primeira evidência de que nossa educação deve se adaptar aos nossos limites biológicos.

\subsection{Repensando Velhos Hábitos}

Se perguntarmos para qualquer pessoa um cenário ideal de se aprender, provavelmente será um local tranquilo, silencioso, e para que seja efetivo, que o estudante mantenha sempre o mesmo ritual e local todos os dias.

Analisando o contexto e ambiente da aprendizagem, os psicólogos D.R. Godden e A.D. Baddeley produziram experimento para testar a hipótese de que as pessoas se lembravam mais do conteúdo estudado quando retornavam ao mesmo ambiente de estudo (Teoria da Restituição). E foram corroborados, assim como a pesquisa que mostrou que alunos que fazem a prova com o mesmo professor que os ensinou tem desempenho 10\% melhor em um teste posterior do que alunos que fazem a prova com outro professor. Até então, as teorias andavam de acordo com a hipótese da Teoria da Restituição.

Em 1984, um grupo de pesquisadores testou a ideia de que alunos que estudassem em silêncio tinham desempenho pior do que os que estudavam com música ao fundo, e os resultados foram positivos neste sentido (Steven M. Smith. Background Music and Context-Dependent Memory). Se encaixam na Teoria da Restituição: A música de fundo se entrelaça subconscientemente no tecido da memória armazenada, enquanto o silêncio é um falta de restituição; não há estímulo para tanto. A conclusão final dos pesquisadores foi de que ter algo acontecendo no ambiente de estudo, como uma música, simplesmente é melhor do que nada (o mesmo vale para a inviolabilidade de um ambiente de estudo silencioso).

É interessante notar, neste ponto do capítulo, que a experiência de estudar tem mais dimensões do que observamos, algumas das quais podem impactar a retenção. Por exemplo, estados mentais internos 
(sentimentos) são impactantes e influentes em nossa memória (Kay Redfield Jamison. An Unquiet Mind: A Memoir of Moods and Madness) assim como o efeito de memória de pessoas bipolares (Herbert Weingartner, Halbert Miller e Dennis L. Murphy. Mood-State-Dependent Retrieval of Verbal Associations) que mostrou que a memória de pessoas com transtorno bipolar depende do estado: Elas se lembram mais do que aconteceu durantes as fases maníacas quando voltam a este estado. Há muito mais variáveis no fenômeno da lembrança que podemos imaginar. Mais um exemplo: $O$ experimento da maconha (James Eric Eich et al. State-Dependent Accessibility of Retrieval Cues in the Retention of a Categorized List), onde 2 grupos, um que fumava um baseado real, outro um placebo, ambos apresentaram resultados altos quando eram compatíveis o momento do estudo e o momento do teste, independente se sobre efeito da droga ou não. O cérebro armazena aproximadamente o mesmo número de palavras, tanto quando moderadamente entorpecido quanto sob nenhum efeito de drogas - as palavras foram absorvidas, de qualquer maneira. No entanto, ele deve organizá-las de uma forma diferente para recuperação posterior. Essa "chave de recuperação" funciona mais facilmente quando o cérebro está no mesmo estado, entorpecido ou sóbrio. Ela se torna supérflua, no entanto, quando as categorias estão escritas na página. Ela não é necessária, porque uma chave externa está disponível. Como escreveram os autores: "A acessibilidade dos estímulos de recuperação codificados no estado entorpecido parece depender, em parte, da restauração desse estado no momento da solicitação da lembrança".

Tendo cada um destas descobertas como base e, portanto, colocando em xeque a ideia de que "estudar sempre no mesmo local é o ideal", Steven M. Smith, Arthur Glenberg e Robert A. Bjork (Environmental Context and Human Memory. Memory \& Cognition) mostrou que alunos que estudaram sempre no mesmo local eram $40 \%$ piores nos testes do que alunos que variaram de ambiente. Esta mesma pesquisa afirma que, se quiseres ter um bom desempenho, varie de ambiente. Como não podemos ver o contexto no qual teremos de realizar algo, é melhor variar as circunstâncias nas quais nos preparamos.

Cada alteração da rotina enriquece ainda mais as habilidades em prática, tornando-as mais nítidas e acessíveis por mais tempo. Esse tipo de experiência em si reforça o aprendizado e torna seu conhecimento cada vez mais independente do entorno. O aprendizado não acontece em um momento, e nem por um só motivo. Acontece em toda e qualquer situação, e por um número imenso de estímulos. É um erro histórico, como resquício do processo de industrialização pensar no aprendizado como linha de montagem, como se uma rotina diariamente idêntica fosse o ideal. Se quiser obter um estudo com o maior nível de aproveitamento possível, adquira novos ambientes, cheiros e sabores ao seu dia-a-dia. 
2.4 A importância do Espaçamento

Estudar um pouco hoje e um pouco amanhã, ou tentar aprender tudo de uma vez? Com certeza essa dúvida já foi enfrentada por você em algum momento, e há um ímpeto natural de, no instante do estudo, querermos aprender de uma única vez, pois somos levamos a pensar que o espaço de tempo entre o agora e o amanhã fará com que esqueçamos do conteúdo.

Junto com essas ideias nos vem o conceito de "estudar antes da prova", que ao contrário do que todos os nossos professores indicam, tem sim resultado. Historicamente, alunos que estudam um dia antes, ou no dia em si, possuem notas boas, porém, podemos dizer que é semelhante a enchermos uma mala de má qualidade com roupas demais. Os itens ficam retidos por um tempo, até explodirem. Portanto, funciona na busca por notas, mas nem tanto para a memorização prolongada do conteúdo.

Para tanto, o mais apropriado é a técnica de aprendizagem distribuída, ou efeito de espaçamento. As pessoas aprendem e mantêm o conteúdo por muito mais tempo quando distribuem (ou espaçam) seu tempo de estudo que quando o concentram. A aprendizagem distribuída, em determinadas situações, pode dobrar a quantidade de informações lembradas depois. Pesquisadores que estudam a aprendizagem dizem que o resultado do estudo de véspera pode ser dramático de um semestre para o outro. No seguinte, ele(a) já esqueceu de todo o conteúdo.

Uma boa analogia e ser feita sobre o efeito do espaçamento é pensar no ato de regar a grama do jardim. Se você o fizer por uma hora e meia, uma vez na semana, terá uma grama verde e bonita no dia seguinte. Porém, se o fizer por três vezes na semana, por apenas trinta minutos, terá um resultado diário, com a grama bonita constantemente. $O$ mesmo vale para a aprendizagem distribuída: Você não leva mais tempo, não trabalha com mais empenho, mas se lembra de mais por mais tempo. O aprendizado espaçado é muito mais eficiente, mas não é aplicado nas escolas, pois é difícil, e é natural que seja, fazer as pessoas estudarem todos os dias. Houve durante anos um negligenciamento em relação a esta prática.

O primeiro pesquisador nesta área é Adolf Jost, que, após replicar experimentos de Ebbinghaus, chegou a uma lei, que leva seu nome: "Se duas associações tiverem a mesma intensidade, mas forem feitas em momentos diferentes, uma nova repetição terá mais valor para a mais antiga." Ou seja, estudar um novo conceito logo depois de aprendê-lo aprofundará pouco - se tanto - a memória; estudá-lo uma hora ou um dia depois, sim.

$\mathrm{Na}$ década de 70, surgiu um questionamento nesta área: Está assentado que este método de espaçamento funciona com sílabas sem sentido 
e em curtos períodos, mas, será que este mesmo método criado por Ebbinghaus e desenvolvido por Jost pode ajudar as pessoas a construir e manter uma base de conhecimento útil na escola e na vida? E então é aí que surge o nosso próximo pesquisador: Harry P. Bahrick.

Para colocar estas ideias anteriores em xeque, o cientista estadunidense criou uma pesquisa onde colocou seus familiares como "cobaias", onde aprendiam listas de palavras estrangeiras (francês ou alemão, dependendo da pessoa) em tempos diferentes: Uma lista seria estudada uma vez a cada duas semanas; outra, uma vez por mês; a terceira, uma vez a cada dois meses. Foi o primeiro experimento com aprendizagem espaçada de longo prazo. Os resultados deste experimento forneceram informações sobre os intervalos máximos para 0 aprendizado permanente (lembrando que 0 experimento testava o método espaçado a longo prazo). A família se lembrou $76 \%$ das palavras em um teste final, em comparação com $56 \%$ em um teste que continha palavras estudadas uma vez a cada duas semanas, em 26 sessões. É uma clara evidência do efeito de espaçamento.

Em relação aos intervalo mínimos de espaçamento, ou seja, de quanto em quanto tempo deve-se estudar a mesma informação, de acordo com - Aprendizado Espaçado? Outro pesquisador, o polonês Piotr Wozniak descobriu que para aprender e reter palavras estrangeiras, definições científicas ou outras informações factuais, é melhor estudar o assunto um dia ou dois após o primeiro contato; em seguida, uma semana depois; então, cerca de um mês mais tarde. Depois disso, os intervalos se tornam mais longos. Esse método é usado por plataformas como Babbel e Memrise, plataformas modernas de aprendizado de línguas. Digamos que o intervalo que temos até o dia de uma prova é de 15 dias. Por conveniência, digamos que o tempo total necessário seja de 9 horas. 0 cronograma ideal, de acordo com o tempo mínimo de Wozniak é: Três horas no dia 1, três horas no dia 8, três horas no dia 14. Em cada sessão de estudo, será revisado o mesmo assunto. No dia do teste, o desempenho será, no mínimo, tão bom quanto se estudássemos 9 horas no dia da véspera. A diferença será que estas informações ficarão retidas por muito mais tempo.

"O estudo de véspera visa a absorção de conteúdo pela intensa prática antes do calvário. Contudo, algo recém-aprendido pode formar algumas associações. Por outro lado, esse mesmo tema repetido em dias diferentes e contextos diferentes, lido, narrado em voz alta, recordado várias vezes, relacionado com outros assuntos e revisado, também é fincado na estrutura mental" (Talks to Teachers on Psychology, 1901).

2.5 A importância dos Testes 
Imagine que você tenha uma prova importante daqui dois meses.Neste tempo, você se prepara, estudando à sua maneira. No dia do teste, você olha para a folha e percebe que está familiarizado com os temas. Tudo está dentro do planejado. No dia do resultado, descobre que ficou entre os piores. Esta poderia ser a história da grande maioria de nós, pois com certeza já passamos por isso na nossa história. A importância de se fazer testes está implícita aqui: Quando esta situação ocorre, fomos vítimas do chamado "Efeito de Fluência". A fluência é a chamada ilusão do conhecimento, onde temos a percepção de que como fórmulas ou argumentos são fáceis de lembrar agora, continuarão sendo amanhã ou depois de amanhã. É o que acontece ao estudarmos mal para uma prova, e no momento reconhecemos o tema, mas o conhecimento, na prática, não nos vêm à tona. Este efeito é o principal culpado por desempenhos abaixo da média em provas importantes. Não a ansiedade ou a "burrice". Não a injustiça ou o azar. A fluência. A melhor maneira de superar esta ilusão é fazendo testes. Quanto mais fácil for trazer um fato à mente, menor o aumento da aprendizagem. É o oposto, mas também verdadeiro, à ideia de "dificuldade desejável": Quanto mais esforço seu cérebro precisa fazer para trazer uma memória à tona, maior o aumento da aprendizagem. Um teste não é apenas uma ferramenta de medição, mas também altera o que lembramos e muda a forma como posteriormente organizamos determinado conhecimento em nossas mentes. E o faz de maneira que melhora muito 0 desempenho posterior. Herbert F. Spitzer, a partir do trabalhos anteriores, tentou então descobrir em que momento era o ideal para se aplicar um teste. Descobriu, através de experimentos com seus alunos, que não só o teste é uma técnica poderosa de estudo, como deve ser aplicado o mais rápido possível. "A lembrança imediata na forma de um teste é um método eficaz de ajudar a retenção da aprendizagem e deve, portanto, ser utilizada com mais frequência; Testes ou exames de desempenho são dispositivos de aprendizagem e não devem ser considerados apenas ferramentas para medir o êxito dos alunos", escreveu o pesquisador.

As descobertas sobre os testes vão em contradição à ideia do esquecimento. Por isso, os pesquisadores Karpicke e Roediger descobriram, através de suas pesquisas, que quando recuperamos um fato com sucesso, ele é rearmazenado na memória de forma diferente. Não só o nível de armazenamento é mais afiado; a própria memória forma ligações novas e diferentes: Liga-se a outros fatos relacionados os quais também recuperamos. A rede de células que contém a memória foi alterada. Usar a memória causa mudanças nela mesmo que não podemos prever. Além disso, os mesmos pesquisadores descobriram a eficiência do chamado pré-teste. Em algumas circunstâncias, as tentativas malsucedidas de 
recuperação (respostas erradas) não são falhas meramente aleatórias. $\mathrm{Na}$ verdade, as próprias tentativas alteram a forma como pensamos e armazenamos as informações contidas nas perguntas. Em alguns tipos de testes, principalmente de múltipla escolha, aprendemos pelo fato de termos escolhido a opção errada, sobretudo quando recebemos a resposta correta logo em seguida. Ou seja, o chute errado aumenta a probabilidade de acertar a pergunta, ou uma relacionada, em um teste posterior. $O$ ato de adivinhar envolve a mente de maneira diferente e mais rigorosa que a memorização direta, aprofundando a gravação das respostas corretas. Significa que o préteste nos faz absorver a informação de uma maneira que o estudo tradicional não faz. De quebra, ainda eliminam 0 efeito da fluência. No fim, o ideal é fingir que sabe. Fazer sem saber é uma ferramenta poderosa de estudo inicial. Depois de um pouco de teoria, se foque na constante prática e teste seu conhecimento a todo momento. Só assim teremos noção do quanto sabemos e não sabemos, ao mesmo tempo que nos melhoramos.

\subsection{A importância do Sono}

O ato de dormir é um dos mecanismos mais importantes da natureza. Durante o sono, o cérebro faz conexões que não acontecem quando estamos acordados. A privação do sono nos torna mais imprudentes, emocionalmente mais frágeis, com menor capacidade de concentração e ainda mais vulneráveis a infecções.

Uma das teorias sobre a função do sono é de que seu propósito principal é a consolidação da memória. Nos últimos anos, os cientistas especialistas em cérebro publicaram uma série de descobertas que sugerem que o sono desempenha um papel crítico na sinalização e armazenamento de memórias importantes, intelectuais e físicas, e também no estabelecimento de conexões sutis, como tocar um instrumento. Em um dado experimento, foi avaliado o desempenho de dois grupos em uma prova; um dos grupos estudava à noite e fazia a prova de manhã, e outro grupo estudava de manhã, e fazia a prova à noite. O grupo que estudava a noite e fazia a prova de manhã se saiu melhor com uma grande diferença: $35 \%$ a mais. O sono age como um consolidador da aprendizagem. $O$ cérebro, durante o sono, mantém-se ativo e em atividade semelhante à quando estamos acordados, em um determinado período do sono. Este período foi chamado pelos pesquisadores de REM (Rapid Eye Movement). A partir desta descoberta, os cientistas começaram a estudar os efeitos da interrupção de determinadas fases do sono, como o REM, para isolar seu impacto sobre habilidades ou assuntos específicos de aprendizagem. As ondas cerebrais têm padrões distintos em cada um desses períodos, o que sugere que diferentes dinâmicas mentais estão em funcionamento em cada momento. 
Os pesquisadores procuraram desvendar se cada fase seria especializada para consolidar um tipo específico de habilidade (geometria, um saque no vôlei ou um texto de Freud).

As pesquisas mostraram que a manutenção básica é feita no sono, e todo o campo de experimentos do sono deram origem à Teoria do Turno da Noite, que revela a diferença de cada estágio do sono:

Fase 1: Ponto de partida. É impossível não passar pela Fase 1 do sono leve quando vamos dormir. Seu papel é associado aos mesmos benefícios do REM.

REM: Ocorrem as tempestades neurais, que surgem para ajudar 0 reconhecimento de padrões, bem como na resolução criativa de problemas e a percepção de relações não aparentes durante o dia. O REM também abrange a interpretação de memórias com cargas emocionais. Os cientistas descrevem o REM como "uma sessão de terapia durante a noite". Fase 2: Esta é a especialista da memória motora. Caso seu sono seja interrompido antes da Fase 2, seu aprendizado motor ficará prejudicado. Fase 3 e 4: Fases de sono profundo. É onde acontece grande parte da retenção. A privação de sono profundo prejudicará na aparência e na memória recente.

Observe que cada fase do sono possui suas especificidades, porém, é bom mantermos em mente que cochilar também é dormir. Em uma série de experimentos ao longo da última década, a pesquisadora Sara Mednik descobriu que cochilos com duração de uma hora a uma hora e meia muitas vezes atingem o sono profundo das ondas lentas e o estágio REM. Pessoas que estudam de manhã e fazem um teste à noite, com um cochilo de $1 \mathrm{~h}$ neste meio tempo saem-se $30 \%$ melhor do que as que não tiram. Com cochilos com duração de uma hora a uma hora e meia, descobrimos, em alguns experimentos, que obtemos quase os mesmo benefícios na consolidação do aprendizado que com um total de oito horas de sono seguidas durante a noite. Cada fase do sono não pode ser analisada e isolada completamente. As fases intensificam cada memória, mas não significa que tratem exclusivamente de uma memória. O tempo de inatividade inconsciente clareia a memória e afia as habilidades, passo necessário para a retenção de ambas, ou seja, dormir também é aprender.

\section{O FUTURO DAS HABILIDADES}

Vimos, no capítulo acima, como aprendemos. A ciência da aprendizagem é um campo liga muito mais com a biologia do cérebro do que 
com práticas pedagógicas. Na realidade, é um passo anterior, tratando de um âmbito mais amplo. As pesquisas apresentadas possuem um cunho empírico da natureza humana, diferentemente deste capítulo. Aqui, veremos, através de pesquisas tão sérias quanto, mas muito mais do âmbito social, como o mercado tende a se movimentar, e inevitavelmente mudar o futuro das habilidades. Será que o que aprendemos hoje nas escolas estará adaptado ao futuro, com as inúmeras mudanças que estão acontecendo dentro do dinamismo social?

Neste capítulo a fonte base foi a pesquisa da Pearson (The Future of Skills: Employment in 2030. London: Pearson and Nesta), uma das maiores empresas de educação do mundo, onde os pesquisadores aplicaram seus métodos com o objetivo de mapear como os empregos tendem a mudar, e as implicações destes fenômenos para as futuras habilidades necessárias, num tempo de espaço limitado de 2018 até 2030.

Estudos recentes à época da pesquisa (antes do atual) trabalhavam maximizando o foco de seus trabalhos no questionamento do risco da automatização dos trabalhos, porém, minimizando os potenciais efeitos da automação na criação de trabalhos, tendendo a ignorar outros tópicos relevantes, como a globalização, envelhecimento da população, urbanização e o crescimento da chamada economia verde. A Pearson chegou à conclusões muito diferentes, e principalmente otimistas em relação à maioria dos outros estudos.

O artigo aponta as habilidades que terão grande demanda, incluindo habilidades intrapessoais, e habilidades de alto processamento cognitivo. Da mesma forma, o estudo consegue prever quais trabalhos poderão ser criados de hoje até 2030.

O estudo desafia o falso alarmismo que contribui para a cultura da aversão ao risco e atrasa a adoção da tecnologia, inovação e crescimento; Ele abrange principalmente Estados Unidos e Reino Unido, que já passam por problemas estruturais de produtividade.

\subsection{A Metodologia da Pesquisa}

A empresa trabalhou, primeiro, com uma análise de tendências. $\mathrm{O}$ artigo começou analisando os fatores de mudança e as interações que devem moldar as estruturas da indústria e mercados de trabalho em 2030. Em seguida, em oficinas e workshops montados e moldados para o artigo, painéis de especialistas foram apresentados a três conjuntos de dez empregos individuais e convidados a debater as perspectivas futuras de cada um à luz das tendências. O primeiro conjunto de dez empregos é escolhido 
aleatoriamente. Os participantes, então, atribuem rótulos às ocupações de acordo com sua visão de suas perspectivas de demanda futura (crescer, permanecer o mesmo, encolher), bem como seu nível de confiança em suas respostas. Para aguçar a previsão, um método de aprendizado ativo é implementado: Os conjuntos subsequentes de ocupações a serem rotulados são escolhidos pelo algoritmo. Especificamente, o algoritmo escolhe ocupações em áreas do espaço de habilidades sobre as quais ele é menos certo, com base nas ocupações anteriormente rotuladas. Este processo é repetido duas vezes para gerar um conjunto de treinamento de 30 ocupações.

Posteriormente, foram usados essas informações para treinar uma machine learning que classificava os dados para gerar previsões para todas as ocupações. Isso se baseia em um conjunto de dados detalhados de 120 habilidades, "skills" e recursos de conhecimento dos quais o serviço do Departamento de Trabalho dos EUA classifica como ocupações. Juntamente com as previsões sobre mudanças na demanda ocupacional, isso permitiu à Pearson estimar as habilidades que, por extensão, provavelmente terão crescimento ou declínio.

A partir dos dados coletados, os resultados do aprendizado da inteligência artificial foram interpretados com atenção especial para as discussões em comparação aos workshops de previsão e destacamos descobertas que são mais relevantes para empregadores, educadores e formuladores de políticas públicas.

3.2 Variáveis Que Influenciam Nas Habilidades Do Futuro.

O futuro do trabalho não é só influenciado pela automação, mas também há de ser feito uma análise dos seguintes fatores para determinar o panorama geral da educação do futuro (a lista foi feita pelos pesquisadores e mostra variáveis que foram observadas como relevantes para o futuro do trabalho):

- Sustentabilidade Ambiental: Consenso da mudança climática se mantém intacta, mas com notáveis disrupturas causadas pelo aquecimento global. Além disso, mudanças estruturais causadas pelo crescimento da economia verde e os "empregos verdes". Apesar disso, sensível às mudanças políticas.

- Urbanização: Incertezas em relação às políticas fiscais e investimento em infraestrutura.

- Aumento da Desigualdade: Aumento na desigualdade de renda e da qualidade dos serviços de saúde. Disparidades da educação, cuidados pessoais, serviços sociais e consumo.

- Incerteza Política: A incerteza afeta negativamente a atividade econômica em setores influenciados pelo governo, tais como finanças, construções, engenharia e cuidados à saúde. 
- Mudanças Tecnológicas: Medo sobre o impacto da automatização dos empregos.

- Globalização: Mercados de trabalhos globais aumentando de forma integrada, aumento do protecionismo e lento aumento no comércio.

- Mudanças Demográficas: Pressão para controlar empregos relacionados à idade, efeitos de onda nas áreas de cuidados pessoais, finanças, educação e recreação (lazer), crescimento da geração "millenial", com padrões de consumo e de comportamento no trabalho muito diferentes.

\subsection{A Necessidade de Mudança das Habilidades}

A sabedoria popular vê essas mudanças como produtos da complementaridade entre tecnologia e mão de obra altamente qualificada. Ou seja, o progresso tecnológico aumenta a demanda por habilidades e 0 investimento em habilidades, por sua vez, sacia essa demanda. Essa estrutura provou ser uma força de trabalho para economistas e pode explicar com sucesso muitas mudanças importantes ao longo do tempo na distribuição de ganhos e empregos nas economias avançadas. No entanto, sua implementação se baseia em uma medida altamente agregada e conceitualmente vaga de habilidade, tipicamente anos de escolaridade. Trabalhos influentes, por exemplo, distinguem entre tarefas cognitivas e manuais, por um lado, e tarefas rotineiras e não-rotineiras, por outro. Comparando as tarefas ao longo do tempo, de 1960 a 1998, elas descobriram que as tarefas cognitivas e manuais rotineiras diminuíram enquanto as tarefas cognitivas e manuais não-rotineiras cresciam em importância. Um crescente corpo de trabalho também ressalta o papel das habilidades "nãocognitivas", incluindo habilidades sociais e habilidades de liderança. Isso deriva da percepção essencial de que os resultados do mercado de trabalho, como ganhos, provavelmente são moldados por uma série de habilidades, na medida em que a capacidade cognitiva medida responde por apenas uma pequena parte da variação desses resultados. Surpreendentemente, ocupações com alta exigência analítica, mas baixa habilidade social encolheram no mesmo período. Uma possível explicação é que as habilidades sociais fornecem as ferramentas para a coordenação rica e versátil que sustenta um ambiente de trabalho produtivo - as sutilezas das quais os computadores ainda precisam dominar. Isso é importante para organizações em ambientes complexos, onde os ganhos clássicos da especialização são eclipsados pela necessidade de se adaptar de forma flexível às circunstâncias em mudança. Medidas de inteligência social também foram validadas por psicólogos e neurocientistas (Poropat, 2009; Woolley, 2010). De fato, o pensamento mais recente rejeita o contraste entre habilidades cognitivas e não cognitivas. Enquanto a razão é amplamente vista como um caminho para maior 
conhecimento e melhor tomada de decisão, alguns argumentam que ela é muito mais diversificada e oportunista - que ela evoluiu principalmente para ajudar os humanos a se justificarem e influenciarem os outros, o que é indispensável para comunicação e cooperação. Como conclusão, acima de tudo o "mercado da educação" deve entender que deve-se tocar no debate conhecimento versus habilidades nos círculos de educação, entendendo que as escolas e a pedagogia devem ensinar habilidades transferíveis - a habilidade de trabalhar em equipe, criar e pensar criticamente - e aqueles que competem com essas habilidades precisam ser rigorosamente fundamentados em uma base de conhecimento para ser dominada (Christodoulou, 2014; Hirsch, 2016).

O questionamento do que devemos ensinar na escola nunca foi tão nebuloso. Se olharmos para a escola como agente de transferência de conhecimento científico, qualquer ensinamento, desde que sério, é válido. Aos olhos da escola e universidades como preparadores do mercado (consequência do capitalismo massacrante que transforma tudo em mercadoria, como Karl Marx observa), temos de nos adaptar, questionando não só o que ensinamos, mas como.

\section{O APRENDIZADO IDEAL NA ESCOLA DO FUTURO}

Desconstruimos mitos da aprendizagem, destrinchamos como funciona o cérebro humano em relação à memorização de informações, e posteriormente ainda passamos por pesquisas que se atentaram à observar como será o futuro das habilidades a serem aprendidas, em conformidade com as dinâmicas de mercado. Unindo estes dois grandes tópicos, discorreremos sobre como a neurociência do aprendizado deve ser implementado no ensino formal, e ainda aplicado para diferentes e novas habilidades necessárias.

Observando os experimentos reunidos por Benedict Carey, o ensino clássico, ainda usado até hoje, principalmente no Brasil se mostra, claro, extremamente antiquado. Estudamos em salas enormes, na mesma hora todos os dias, durante a mesma quantidade de tempo; Professores dão matérias mas não aplicam as provas, e nestas cobram conteúdos de memorização, e não testam habilidades, como deveriam. Condenamos as crianças (e nós mesmos) por terem preguiça ou sono de estudar, e achamos que esquecer é uma falha da memória. Num mundo ideal onde a aprendizagem se molda às novas descobertas, como deveria, a escola de futuro, ser?

Antes de tudo, principalmente, as grades curriculares cobrem muito mais do que o tempo permite. Estudar Direito em 5 anos, por exemplo, é 
o suficiente para estudar tudo superficialmente, e nada com profundidade. Esse cobrança para os professores darem quantidades enorme de matérias faz com que o aprendizado não seja valorizado, com que o professor não dê atenção especial a que cada um necessita. Não há limite de tempo para a aprendizagem, e colocar um prazo fim, na realidade, atrapalha a organização das ideias. O conhecimento deve ser flexível, leve, bem planejado, espaçada, de forma que esteja no nosso dia-a-dia, sem cobranças massivas. Como observa Benedict Carey no final de seu livro: "Aprender é tudo que fazemos". Quanto maior for a sistematização e automatização do conhecimento, mais desconectada da natureza de nosso cérebro estará. Perceba que, acima de tudo, o conhecimento deve estar adaptado à natureza humana. Há a necessidade de que se molde o sistema educacional para a realidade evolutiva do nosso cérebro. A informação presente a todo momento, um bom planejamento e uma customização e acompanhamento a cada aluno, focado não em ter uma profissão, mas em adquirir habilidades, e com elas entrarem no mercado do futuro. Esta é a escola do futuro. O aluno do futuro, querendo ou não, provavelmente não precisará escolher uma profissão, e esta é a conclusão mais significante. Ao mesmo tempo, será o estudante que mais passará tempo estudando na história, enquanto não possuirá formações fechadas. O mercado não mais pede que se saiba fazer uma função, mas várias. Inteligência emocional e habilidade de lidar com o próximo nunca foram tão valorizadas, dado que comprova que habilidades que nunca foram valorizadas no mercado, serão.

Em alguns anos, escolheremos não um curso de graduação, mas matérias específicas, ou mini-cursos (já é uma tendência). Ultrapassado será o profissional que irá aprender tudo de Direito, e moderno será o profissional que irá aprender Direito Constitucional, Ciência de Dados, Gastronomia e Artes ao mesmo tempo. Nas grandes empresas, diferentes áreas são intercambiáveis e cada produto ou serviço pede habilidades específicas.

\section{CONSIDERAÇÕES FINAIS}

A maneira que sempre aprendemos não nos fez bem, provavelmente, como já destrinchado no artigo. As próximas gerações enfrentarão mudanças que, apesar das pesquisas, mal podemos prever. Não podemos ser, em hipótese nenhuma, conservadores no modo de aprender, uma vez que o dinamismo da sociedade aumenta, e tende a aumentar cada vez mais. Não fomos biologicamente "construídos" para sentarmos em frente à uma mesa e passarmos três horas lendo um livro. Esta é uma invenção do homem moderno. Logo, aprendemos não desta maneira, mas indo à campo, praticando, diariamente. Não somos máquinas, apesar do sistema de ensino clássico nos fazer pensar que somos. 


\section{REFERÊNCIAS}

CAREY, Benedict. Como Aprendemos: A surpreendente verdade sobre quando, como e por que o aprendizado acontece . 1. ed. Rio de Janeiro: Elsevier, 2015.

PEARSON. The Future of Skills: Employment in 2030. Londres, 2018. 


\title{
TURISMO PEDAGÓGICO: Uma ferramenta para o desenvolvimento
}

\author{
MAZARON, André Eduardo Silveira \\ Mestrando - Uni-FACEF \\ mazaron@gmail.com \\ FADEL, Barbara \\ Doutora - Uni-FACEF \\ bafadel@facef.br
}

\section{INTRODUÇÃO}

$\mathrm{O}$ ato de se deslocar, é algo comum entre o homem desde a préhistória. O homem saía para caçar, comer, procurar locais seguros para abrigo, dentre outros fatores.

Podemos dizer então que o turismo existe desde o primórdio da vida humana.

Para alguns autores o turismo teve seu início no século VIII a.c., na Grécia, porque as pessoas viajavam para ver os jogos olímpicos a cada quatro anos; outros autores acreditam que os primeiros viajantes foram os fenícios, por terem sido os inventores da moeda e do comércio, e é muito provável que, se fosse realizada uma pesquisa em tempos anteriores, e em outras culturas, além da greco-romana, encontrar-se-iam antecedentes ainda mais remotos, chegando-se a supor que o ser humano sempre viajou, seja definitivamente ou temporariamente (BARRETO, 2001).

O turismo como conhecemos hoje, deve-se muito ao fato do desenvolvimento tecnológico, a construção de estradas e ferrovias trouxe uma grande facilidade no deslocamento de pessoas. Começamos então o Turismo Moderno, a partir do século XIX. "Em 1830, a ferrovia Liverpool-Manchester, na Inglaterra, foi a primeira a preocupar-se mais com o passageiro do que com carga" (BARRETO, 2001)."

O século XIX foi marcado por Thomas Cook, suas atividades para com o turismo, configuraram as primeiras viagens agenciadas. Thomas Cook começou em 1841, quando foi a um evento cujo tema tratava contra o alcoolismo, em Leicester. Em um novo encontro, em Loughborough, Thomas Cook, comprou e revendeu bilhetes para 570 pessoas, tendo então caracterizado a primeira viagem agenciada.

A partir de então, Cook começa a trabalhar com viagens cada vez mais completas, nascendo daí o Turismo Coletivo. 
A palavra turismo vem acompanhada de diversas definições, sejam elas ligadas ao modo econômico, ou a um modo técnico. A primeira definição de turismo, surge em 1911, pela Universidade de Berlim, ao estudar economia relacionada ao turismo, e trouxe como

[...] conceito que compreende todos os processos, especialmente econômicos, que se manifestam na chegada, na permanência e na saída do turista de um determinado município, estado ou país."(SCHATTENHOFEN, 1911, p. 76 apud BADARÓ, 2005, p. 19)

Através dessa primeira definição de turismo vários outros autores também tentaram definir o real significado de turismo, e seguindo uma linha de pensamento econômico, em 1975, o Departamento Australiano de Turismo e Recreação define turismo como uma importante indústria, nacionalmente identificável. Compreende um amplo corte transversal de atividades componentes, incluindo a provisão de transporte, alojamento, recreação, alimentação e serviços afins.

No Brasil temos alguns autores que também criaram algumas definições sobre turismo, de modo holístico, e não apenas focado como uma atividade econômica.

o turismo é um elaborado e complexo processo de decisão sobre o que visitar, onde, como e a que preço. Nesse processo influem inúmeros fatores de realização pessoal e social de natureza motivacional, econômica, cultural, ecológica e científica que ditam a escolha dos destinos, a permanência, os meios de transporte e o alojamento, bem como o objetivo da viagem em si para a fruição tanto material como subjetiva dos conteúdos de sonhos, desejos, de imaginação projetiva, de enriquecimento histórico-humanístico, profissional e de expansão de negócios. (BENI, 2001, p.37)

Outro autor brasileiro que definiu turismo, é Alexandre Panosso Netto, que trouxe o turismo como:

um fenômeno originado da saída e retorno do ser humano do seu lugar habitual de residência, por motivos diversos que podem ser revelados ou ocultos, que pressupões hospitalidade, encontro e comunicação com outras pessoas, empresas que oferecem condições e tecnologia para a efetivação do ato de ir e vir, gerando experiências sensoriais e psicológicas e efeitos positivos e negativos no meio ambiente econômico, político, ecológico e sociocultural. (PANOSSO NETTO, p.45 apud TRIGO, 2009, p. 16)

Analisando as definições, sendo elas relacionadas a uma visão econômica ou a uma visão holística, podemos dizer que ambas estão correlacionadas.

E, em outra perspectiva: 
Outro elemento essencial para definir turismo é todo o arcabouço, toda preparação envolvida. Para que uma pessoa possa viajar existe toda uma equipe que faz o planejamento do receptor e que presta serviços no local; que providencia vias de acesso, saneamento básico, alojamento, alimentação, recreação. (BARRETO, 2001, p.14)

Através dos diversos conceitos, pode-se ver o turismo como um conjunto de atividades e infraestruturas que, através de um planejamento, se torna um produto. Este produto turístico será ofertado para uma pessoa seguindo diversos fatores como, preço, motivações, experiências, qualidade, etc.

O tipo de turismo vai variar de acordo com as motivações, perfis e interesses do praticante.

Através destas motivações, foram surgindo diversos segmentos na área.

Os segmentos vieram para satisfazer as necessidades de cada indivíduo, fazendo com que o consumo do viajante seja específico aos seus interesses.

Temos um mercado turístico composto por diversos produtos que são ofertados para o consumo do viajante, estes produtos são relacionados diretamente ou indiretamente para o turismo. O turismo como atividade econômica se deve ao fato, do viajante consumir os produtos que são ofertados, utilizar de meios de transportes, meios de hospedagem, guias de turismo, visitações à diversos atrativos turísticos, dentre outros produtos.

Com a segmentação do turismo, as motivações de viagens são diversas, e não exclusivamente a lazer, porém o consumo dos produtos se mantém. O que varia de um segmento a outro é o interesse do turista.

Esses diversos segmentos do turismo tem um grande poder de desenvolvimento na área em que acontece. O poder de transformação de uma localidade através de turismo, é principalmente relacionado os aspectos sociais, econômicos, culturais e ambientais. Segundo Beni (2001) "O turismo provoca o desenvolvimento intersetorial, em função do efeito multiplicador do investimento e dos fortes crescimentos da demanda interna e receptiva. É atividade excelente para obtenção de melhores resultados no desenvolvimento e planejamento regional ou territorial."

Sendo assim, podemos entender o turismo como uma forma de desenvolvimento regional, devido à estrutura que ele necessita para que seja ofertado um produto de qualidade ao consumidor final, então o turismo tem um grande potencial na transformação de uma localidade, quando bem planejado. 


\title{
2. O TURISMO PEDAGÓGICO
}

O turismo pedagógico ou turismo educacional, é uma prática antiga que visa levar estudantes para um ambiente fora da sala de aula e unir teoria e prática, tendo então um maior desenvolvimento educacional.

\begin{abstract}
"Retomada da antiga prática amplamente utilizada na Europa e principalmente no Estados Unidos por colégios e universidades particulares e também adotada no Brasil por algumas escolas de elite, que consistia na organização de viagens culturais mediante 0 acompanhamento de professores especializados da própria instituição de ensino com programa de aulas e visitas a pontos históricos ou de interesse para o desenvolvimento educacional dos estudantes. Hoje, pouquíssimas instituições ainda mantêm essa prática pedagógica em destinações no exterior, enquanto expandemse as viagens regionais e nacionais com a mesma finalidade, estendendo-se agora aos estudos de ecossistemas e outros aspectos do meio ambiente" (BENI, 2001, p.432).
\end{abstract}

Tal atividade se mostra crescente no Brasil, tendo em vista que é uma alternativa viável de desenvolvimento social do estudante, onde através das práticas pedagógicas, o aluno tem a possibilidade de interação com o meio e interação com outros estudantes. As viagens pedagógicas conta com o caráter lúdico, o que torna a interação do estudante com o ambiente mais descontraído e uma prática eficaz.

"A educação é um processo de mão dupla, que envolve apreensão cultural; portanto é muito mais do que fixar conteúdos. [...] Nada é mais óbvio que o fato de que a educação não ocorre apenas nesse espaço, mas também além dele." (SANTOS, 2018, p.77)

Uma disciplina aplicada em sala de aula, pode ser facilmente relacionada com um atrativo turístico, um monumento, um ambiente cultural ou ambiental, sendo uma alternativa importante no processo de ensino e aprendizagem.

O atrativo turístico, carrega junto a ele um contexto histórico, modelos arquitetônicos, estudo sobre educação ambiental, geográfico, dentre outras possibilidades através do mundo real, conseguindo então contextualizar a teoria com a prática.

A interdisciplinaridade, o ganho social e conscientização cultural e ambiental são fatores importantes que tornam o turismo pedagógico uma prática de grande interesse das escolas.

"O turismo pedagógico é uma maneira de oferecer aos estudantes a oportunidade de conhecer melhor uma determinada região e vivenciar a história, as tradições, os hábitos e os costumes da população local, 
por meio de aulas práticas no próprio destino receptor." (MOLETTA, 2003, p.11 apud. GERONI, 2018 p.41)

Conhecer a própria cultura através de práticas lúdicas e recreativas, faz com que um estudante tenha um maior desenvolvimento educacional e social. A união da teoria vista em sala, com a prática no meio em que está se visitando, torna o processo de ensino mais fácil e claro para 0 entendimento do indivíduo. A sensibilidade no contato com os atrativos turísticos, faz com que o turismo pedagógico seja uma ferramenta importante para o crescimento dos estudantes. A interação com o meio através das atividades recreativas e lúdicas, faz com que a visita tenha um grande valor no processo de aprendizagem do indivíduo.

"As atividades extra-classe são muito mais do que momentos de recreação ou fuga da rotina diária: são grandes oportunidades de transmissão de conhecimentos. No caso das viagens turísticas educativas com temática cultural, acredita-se como necessário o fato de elas constituírem uma linguagem em que se articula um conjunto importante de valores históricos e contemporâneos, na tentativa de induzir atitudes de conscientização, respeito e proteção por parte dos visitantes e dos visitados." (MILAN, 2007, p. 14)

Podemos então entender o Turismo pedagógico como uma prática educativa extraclasse, onde estudantes conseguem unir a teoria vista em sala de aula com a prática através de uma vivência, junto a um monumento, parques, e atrativos turísticos em geral, acompanhado de um professor especialista, guia de turismo e outros profissionais competentes buscando o desenvolvimento social e educacional do aluno.

As ofertas turísticas tendem a ser grandes aliadas neste segmento, pois uma unidade educacional (escola), vai necessitar de uma estrutura para efetuar a viagem ou passeio. Neste caso, vários profissionais serão envolvidos para que possa ser realizado o turismo pedagógico.

Um segmento que está crescendo no Brasil é o turismo pedagógico, o qual envolve atividades voltadas à educação, ao aprendizado, ao conhecimento de 'algo' que possa acrescentar ao turista, isto é, que possibilite a ele ter uma visão da realidade. $E$ esse segmento requer atenção e profissionalismo por parte de seus planejadores. A viagem de estudo tem a capacidade de promover o desenvolvimento humano, social e educacional, podendo servir ao ensino. (ANSARAH, 2005, p.293 apud. GERONI, 2018 p. 104).

As escolas não buscam apenas um roteiro para o ensino de determinada disciplina, mas sim roteiros completos, onde a interdisciplinaridade 
se torna ponto fundamental. As atividades de recreação, momentos lúdicos e de lazer são ferramentas essenciais no turismo pedagógico, fazendo com que o estudante tenha de forma interdisciplinar uma vivência completa no meio em que está se visitando.

"Deve-se levar em conta ainda que, se o conteúdo das atividades de lazer pode ser altamente "educativo", também a forma como são desenvolvidas abre possibilidades "pedagógicas" muito grandes, uma vez que o componente lúdico, do jogo, do brinquedo, do "faz-deconta", que permeia o lazer é uma espécie de denúncia da "realidade", deixando clara a contradição entre obrigação e prazer." (MARCELLINO, 2002, p.14)

objetivo do turismo pedagógico é transmitir através da vivência e interação com o meio a absorção de conteúdo. Pode -se dizer que é um momento de absorção de conhecimento, interpretação e criação de um significado.

Como destaca Choo (2003), interpretação é o processo pelo qual os indivíduos de uma organização criam e observam o ambiente que os cerca.

Para Choo (2003), o resultado da interpretação é uma série de dados ambíguos, não interpretados, que fornecem material para outros processos de criação de significado.

Quadro 1 - Os três modelos de uso da informação organizacional

\begin{tabular}{|c|c|c|c|}
\hline Modo & Idéia central & Resultados & Principais conceitos \\
\hline $\begin{array}{l}\text { Criaçāo de } \\
\text { significado }\end{array}$ & $\begin{array}{l}\text { Organização } \\
\text { interpretativa: } \\
\text { Mudança ambiental } \rightarrow \\
\text { Dar sentido aos dados } \\
\text { ambiguos por meio } \\
\text { de interpretaçöes. } \\
\text { A informação é } \\
\text { interpretada. }\end{array}$ & $\begin{array}{l}\text { Ambientes } \\
\text { interpretados e } \\
\text { interpretaçōes } \\
\text { partilhadas para } \\
\text { criar significado. }\end{array}$ & $\begin{array}{l}\text { interpretaçāo, seleção, } \\
\text { retenção. }\end{array}$ \\
\hline $\begin{array}{l}\text { Construçăo do } \\
\text { conhecimento }\end{array}$ & $\begin{array}{l}\text { Organização aprendiz: } \\
\text { Conhecimento } \\
\text { existente } \rightarrow \text { Criar } \\
\text { novos conhecimentos } \\
\text { por meio da conversão } \\
\text { e da partilha dos } \\
\text { conhecimentos. } \\
\text { A informação é } \\
\text { convertida. }\end{array}$ & $\begin{array}{l}\text { Novos conhecimentos } \\
\text { explícitos e tácitos } \\
\text { para a inovação. }\end{array}$ & $\begin{array}{l}\text { Conhecimento tácito. } \\
\text { Conhecimento } \\
\text { explícito. Conversăo } \\
\text { do conhecimento. }\end{array}$ \\
\hline $\begin{array}{l}\text { Tomada de } \\
\text { decisōes }\end{array}$ & $\begin{array}{l}\text { Organizaçāo racional: } \\
\text { Problema } \rightarrow \text { Buscar } \\
\text { e selecionar alternativas } \\
\text { de acordo com os } \\
\text { objetivos e preferências. } \\
\text { A informaçāo é } \\
\text { analisada. }\end{array}$ & $\begin{array}{l}\text { Decisōes levam a } \\
\text { um comportamento } \\
\text { racional e orientado } \\
\text { para os objetivos. }\end{array}$ & $\begin{array}{l}\text { Racionalidade limitada. } \\
\text { Premissas decisorias. } \\
\text { Regras e rotinas. }\end{array}$ \\
\hline
\end{tabular}


FONTE: CHOO. 2003, p.46

Pode-se relacionar a interpretação de Choo à prática do turismo pedagógico como um processo de retenção de conhecimento para o estudante passando por alguns processos para a criação do significado final.

Retenção é o processo pelo qual os produtos de uma bem-sucedida criação de significado - ou seja, ambientes interpretados e significativos - são armazenados para serem recuperados no futuro como possíveis significados a serem atribuídos a novas situações ambíguas." (CHOO, 2003, p.133)

Pela perspectiva de Provonost (2011, p.121) "é preciso, então, considerar as funções educativas que a escola pode praticar fora de seu campo tradicional de ensino, assim como as dimensões educativas presentes na cultura."

Um ambiente onde o estudante consegue visualizar e entender de forma clara toda a teoria vista em sala de aula, tem um efeito positivo no desenvolvimento educacional. Toda a questão histórica e cultural que o aluno consegue aprender no meio em que está se visitando, começa a fazer sentido também na valorização do espaço em que vive, sendo assim uma importante ferramenta de desenvolvimento social.

Através das atividades propostas no ambiente extraclasse, 0 aluno tem a oportunidade de uma vivência em grupo diferenciada, agregando na autonomia do indivíduo, crescimento social e cultural.

A curiosidade como inquietação indagadora, como inclinação ao desvelamento de algo, como pergunta verbalizada ou não, como procura de esclarecimento, como sinal de atenção que sugere alerta, faz parte do fenômeno vital. Não haveria criatividade sem a curiosidade que nos move e que nos põe pacientemente impacientes diante do mundo que não fizemos, acrescentando a ele algo que fazemos. (FREIRE, 2016, p.33)

A prática do turismo pedagógico, faz com que o aluno tenha autonomia no seu processo de aprendizagem, despertando assim, uma curiosidade sobre o meio que o cerca. Conforme Freire (2016), o exercício da curiosidade convoca a imaginação, a intuição, as emoções; sendo assim a prática da viagem educacional se torna uma importante ferramenta no processo de desenvolvimento do estudante. Conforme já visto anteriormente, o 
turismo pedagógico além de facilitar o entendimento de uma determinada disciplina, desperta o interesse do estudante para com o meio que em está visitando, e assim compreendendo de forma mais clara o contexto trabalhado.

\section{OPERACIONALIZAÇÃO DO TURISMO PEDAGÓGICO}

O turismo pedagógico vem carregado de diversos benefícios para as comunidades receptoras. Nesta atividade, é necessário ter uma estrutura adequada para receber os estudantes, e então produzir uma oferta turística de qualidade e com propósitos pré-definidos.

Uma estrutura bem formada para a construção de um produto turístico, depende de algumas partes que se relacionam, assim formando um sistema. Beni, define um Sistema de Turismo (SISTUR):

\footnotetext{
"Pode-se definir sistema como um conjunto de partes que interagem de modo a atingir um determinado fim, de acordo com um plano ou princípio; ou conjunto de procedimentos, doutrinas, ideias ou princípios, logicamente ordenados e coesos com intenção de descrever, explicar ou dirigir o funcionamento de um todo." (BENI, 2001, p.23)
}

Assim, Beni classifica sistema através de um conjunto de fatores interdependentes, para a criação de um produto turístico.

Pode-se dizer que o Sistur é um processo entre três elementos que se ligam para a formação do produto turístico:
a. Relações Ambientais
b. Organização Estrutural
c. Ações Operacionais

Das Relações Ambientais temos os subsistemas Social, Ecológico, Econômico e Cultural. O subsistema Social, trata-se das relações entre os indivíduos de uma comunidade, e as relações entre a comunidade e seus visitantes, e como essas relações podem contribuir para a formação do turismo.

O subsistema ecológico trata-se do local em que a comunidade está inserida, e quais as consequências do turismo para o meio ambiente. 
O subsistema econômico, tem como objetivo a análise da atividade turística como atividade econômica

E o subsistema cultural tem como característica, analisar o contexto cultural existente na comunidade receptora e suas potencialidades para o turismo.

A Organização Estrutural é dividida em Superestrutura e Infraestrutura, sendo a superestrutura um complexo de ações públicas e/ou privadas que tem como objetivo o planejamento da atividade turística; e a infraestrutura é entendido como a estrutura física e de apoio para a prática do turismo.

E as Ações Operacionais como parte do Sistur, é entendido como o mercado; para Beni (2001) no estudo do mercado existem três questões centrais: o que produzir, como produzir e para quem produzir. A partir desta afirmação, entende-se que um produto turístico é criado através da oferta de um produto com determinado potencial de mercado.

A relação do Sistur com o objeto de pesquisa, o turismo pedagógico, pode-se compreender que é um produto com potencial quando se une com o interesse de escolas e professores, podendo ser utilizado como uma ferramenta de educação e desenvolvimento local e pessoal.

\section{CONSIDERAÇÕES FINAIS}

Conclui-se que o turismo pedagógico é uma aplicação prática das teorias vistas em sala de aula, incentivando os alunos à busca de maior conhecimento, estimulando-os a experiências sociais sendo então uma ferramenta importante no processo de ensino e aprendizagem.

É através desse tipo de viagem educacional, que o estudante consegue ser inserido ao meio que está sendo visitado, e assim ter uma assimilação do conteúdo visto anteriormente em sala de aula.

Uma viagem pedagógica, é uma importante ferramenta no processo de formação do estudante, tendo em vista que é um momento de conscientização cultural sobre o espaço em que vive, pois possui todo o contexto histórico daquela determinada localidade, a questão ambiental, cultural, sendo uma ferramenta importante no processo de ensino, assim o estudante pode ter um olhar diferente sobre a história e valores de sua região.

Conhecer a própria cultura através de atividades educacionais faz com o que o estudante se sinta integrado naquele determinado meio, e assim tenha um maior desenvolvimento social através da valorização e preservação.

Temos o turismo pedagógico como um grande aliado no processo de desenvolvimento regional, já que como vimos no decorrer da pesquisa, o 
turismo exige de uma série de planejamentos para que o produto ofertado seja de qualidade, atendendo às expectativas da demanda. O produto turístico é criado através das necessidades e motivações da demanda, em conjunto de boa estrutura de serviços, sejam eles ligados diretamente ou indiretamente ao turismo.

O turismo regional como ferramenta de desenvolvimento acontece por exigir ao espaço uma boa estrutura e planejamento, e através do quanto o estudante pode ajudar nesse processo, através do ganho social, conscientização e conservação do espaço.

Baseado em Beni (2001), Santos (2018), Provonost (2011), Choo (2003), dentre outros autores, este trabalho visa contribuir para com os professores e gestores da educação motivando-os a uma aplicação prática deste segmento do turismo para melhor introspecção das informações e assim incentivar seus alunos na busca de conhecimentos e novas experiências.

\section{REFERÊNCIAS}

BADARÓ, Rui Aurélio de Lacerda. Direito do Turismo: História e Legislação no Brasil e no exterior. São Paulo: Editora Senac São Paulo, 2. Ed, 2005

BARRETTO, Margarita. Manual de Iniciação ao estudo do turismo, 11. ed. Campinas: Papirus, 2001.

BENI, Mário Carlos. Análise Estrutural do Turismo. São Paulo: Editora Senac São Paulo, 2001

$\mathrm{CHOO}, \mathrm{C} . \mathrm{W}$. A organização do conhecimento: como as organizações usam a informação para criar significado, construir conhecimento e tomar decisões. São Paulo: Senac, 2003

FREIRE, Paulo. Pedagogia da autonomia: saberes necessários à prática educativa. 53. Ed. Rio de Janeiro: Paz e Terra, 2016.

GERONI, Ivone Mazutti De. Turismo pedagógico como ferramenta na construção do desenvolvimento regional. Dissertação (Mestrado em Desenvolvimento Regional) - Canoinhas/SC: Universidade do Contestado, 2018.

MARCELINO, Nelson Carvalho. Estudos do lazer: uma introdução. 3. ed. Campinas: SP: Autores Associados, 2002. 
MILAN, Priscila Loro. "Viajar para aprender": Turismo Pedagógico na Região dos Campos Gerais - PR, Balneário Camboriú/SC: Universidade do Vale do Itajaí, 2007

PRONOVOST, Gilles. Introdução à sociologia do lazer, São Paulo: Editora Senac, 2011.

SANTOS, Rosana Fernandes dos; PACHECO, Reinaldo. Lazeres, São Paulo: Editora Senac, 2018.

TRIGO, Luiz Gonzaga Godoi. Turismo básico, 8. Ed. São Paulo: Editora Senac, 2009 


\title{
A IMPORTÂNCIA DA ASSIMILIAÇÃO DE CONTEÚDOS POR MEIO DA CINEMATOGRAFIA: os meandros e dificuldades da docência
}

\author{
LIPI FILHO, Luiz Marcelo \\ Graduando em História - Unesp \\ luizmarcelolipi98@gmail.com \\ VILLELA, Vanessa Moscardini de Oliveira Junqueira \\ Graduada em História - Unesp \\ vanessamojvillela@gmail.com \\ SILVA, Márcia Pereira \\ Coordenadora PIBID - UNESP \\ marciapereirasilva@gmail.com
}

\section{INTRODUÇÃO}

É preciso analisar a importância do Cinema - que foi criado pelos irmãos Auguste e Louis Lumière, no ano de 1895- no tocante à apresentação de novos fatos históricos para a sociedade, haja vista um maior entendimento por meio de quem assiste devido à ludicidade encontrada pelos diretores e roteiristas nos filmes e na expressão de conteúdos, tanto gerais quanto especificamente históricos. Primeiramente aqueles que realizaram e imaginaram o cinema como uma arte industrial, um movimento automático, um movimento feito diretamente pela imagem, e, além disso, tentaram demonstrar como é o funcionamento desse movimento, quando o mesmo se torna automático tratando da essência artística da imagem, tentaram mostrar que é aí que se produz um choque no pensamento. Portanto, o Cinema traz consigo o essencial de outras artes, transformando em algo potente o que era apenas possibilidade. Contudo, é de suma importância ressaltar que os filmes de cunho histórico muitas vezes não estão ligados à realidade em sua totalidade, trazendo assim, de certa forma, uma concepção equivocada de algumas conjunturas e, além de equivocada, muitas vezes fantasiosa sobre os acontecimentos.

O cinema, desde quando foi criado, utilizou-se da História para a criação de conteúdos e, como uma via de mão dupla, a História utiliza-se dos filmes como objeto de estudo, trabalhando com ele de forma a analisar as dificuldades do seu tempo e os desdobramentos daquele período.

Como o Cinema desde o início se serviu da História como fonte criativa, de maneira natural a História então o elege como objeto de pesquisa, principalmente ao tratar dos problemas de seu tempo, 
falando e analisando as inquietações do momento em que o filme foi produzido. (BÍCEGO, 2004, p.12).

Compreender o que o cinema significa implica também de certa forma afastar-se das imagens, para assim compreender os mecanismos de produção de sentido e, concomitantemente, entender que é exatamente esse afastamento, somado ao distanciamento relacionado à nossa experiência do dia-a-dia, levando-nos assim para um universo diferente, que nos causa uma grande fascinação e nos seduz pela arte cinematográfica.

Para dialogar com a outra parte do artigo, deve-se trabalhar também o papel do Historiador/Professor nisso tudo. A análise da documentação, a interpretação dos fatos, a tentativa de compreender alguma conjuntura ou período por meio de relatos ou dados de certa forma documentados traz ao Historiador uma tarefa bastante árdua. Ao passo que na leitura de alguma documentação, é importante observar que o trabalho feito pelo profissional sempre tende a algum lado, nunca é imparcial. Compreender que exista quem defenda determinada posição e quem seja contra outra, é uma tarefa fundamental. Um bom exemplo disso é a diferença para as maneiras de se fazer e se escrever História. Existem algumas vertentes específicas que defendem maneiras singulares de se escrever História. Para o entendimento ocorrer de forma mais tranquila, é preciso citar algumas dessas maneiras, começando pelo Positivismo. Auguste Comte, conhecido como o Pai do positivismo, trata a maneira de se enxergar a História por meio do conhecimento científico, sendo impossível alcançar o conhecimento verdadeiro. Portanto, segundo essa vertente, o progresso depende exclusivamente desses avanços científicos. Já a escola dos Annales, faz uma crítica ferrenha no modo de produzir História dos Positivistas. Eles iniciaram seus trabalhos por volta do ano de 1929, e possuem esse nome, pois se organizavam em torno de um periódico francês conhecido como Annales d’histoireéconomiqueetsociale (Anais de História econômica e social), local onde eram publicados seus principais trabalhos. Os fundadores dessa Escola Historiográfica foram Marc Bloch e Lucien Febvre. A forma de trabalhar a História dessa escola francesa, como já supracitado combatia os positivistas e defendia um desenvolvimento da História que levasse em conta o acréscimo de novas fontes, como à pesquisa histórica e realização de uma abordagem diferente da trazida pelos Positivistas. Outra maneira de se entender a História é por meio do método Marxista. Pensado pelo alemão Karl Heinrich Marx, trouxe uma outra perspectiva de compreensão do passado. O autor alemão colocou o Homem como sujeito da História e deu voz às massas, dando a elas grande importância nos feitos históricos. O método que o pensador alemão utilizava ficou conhecido como Materialismo Histórico Dialético. Com essas formas apresentadas como exemplo, é possível entender as diversas maneiras de atuação do Historiador na sociedade e quais são os métodos que ele tem para poder escrever a História. 
Agora é fundamental que haja uma mistura entre essas duas formas de conhecimento: unir o Cinema com História dentro da sala de aula. Trazer a cinematografia para o cotidiano das aulas de História nas escolas pode significar um afastamento das formas ditas arcaicas e tradicionais de ministrar os conteúdos e, concomitante a isso, é possível trazer novas alternativas ao ensino de História.

Os filmes além de muitas vezes passarem conteúdos de forma mais didática, podem trazer também consigo uma criticidade sobre determinados temas e, com isso, apresentar soluções mais práticas e mais lúcidas das apresentadas pelo professor somente na aula expositiva.

Mas o principal ponto a ser tratado nesse artigo é o de como os filmes podem agregar na hora do entendimento de alguns conceitos passados pelo professor durante a aula ministrada. Com essa mistura de aula expositiva somada à cinematografia pode ser positiva, entrando no cotidiano do aluno, passando apenas de uma mera obrigação o entendimento da forma tradicional, mas também trazendo para o lazer, para um espaço que faz parte do dia-a-dia do discente, tornando assim o aprendizado mais leve e visto como mais prazeroso, dando voz a novas formas pedagógicas.

\section{OBJETIVOS}

Os principais objetivos dessa pesquisa são mostrar que o Cinema pode ser visto como um instrumento do progresso científico e, além disso, uma ferramenta que é capaz de mostrar, por meio das ficções, documentários, romances e entre outros gêneros, ilustrações que trazem conjunturas específicas de cada tema trabalhado.

É interessante tratar também que o cinema, por sua forma ímpar de se expressar, quebra um pouco as correntes ideológicas de seu tempo, trazendo assim, por meio da arte e de outros elementos, visões e interpretações inéditas sobre determinados fatos tratados em filmes, posições que podem ser entendidas como uma alternativa aos padrões.

[...] sem falar em quase todos os filmes de Godard, manifestam uma independência diante das correntes ideológicas dominantes, criando e propondo uma visão de mundo inédita, própria de cada um deles, o que vigorosamente suscita uma nova tomada de consciência, de tal forma que as instituições ideológicas instauradas (partidos políticos, Igrejas, etc.) entram em disputa e rejeitam tais obras, como se apenas essas instituições tivessem o direito de se expressar em nome de Deus, da nação ou do proletariado, e como se apenas elas se dispusessem de outra legitimidade além daquela que elas próprias se outorgaram. (FERRO, 1992, p.14). 
É importante estudar a intervenção do Cinema na sociedade, pois o mesmo acontece de acordo com certo número de ações que tornam o filme eficaz, operatório. Com certeza, a capacidade de tornar o filme realizável está ligada ao tipo de sociedade produtora do filme e também àquela que recepciona o mesmo, visto que, as diferentes culturas interpretam, agem e reagem de diferentes maneiras sobre o mesmo acontecimento. Com isso, além da importância de passar filmes aos alunos com o intuito de assimilação dos conceitos, é preciso fazer mais que isso: acompanhada dos curtas ou longas metragens, se faz necessária anexar aos filmes diferentes análises e interpretações sobre o mesmo assunto trabalhado, trazendo assim a diversidade. A diversidade, se não for o tópico mais importante para compreensão da realidade, é um dos pontos que mais devem ser trabalhados, tendo em vista a enorme riqueza e variedade de relatos profissionais, complementando assim, de uma melhor forma, uma formação mais ampla e com um leque de informações, visões e versões maiores. Portanto, a produção de um filme em um parâmetro histórico produz rivalidades, conflitos, lutas de influência, entre outros fatores.

Sobre a necessidade de entendimento, é possível fazer duas comparações: a leitura histórica do filme e a leitura cinematográfica da história. São eixos a serem seguidos para as pessoas que se interrogam a respeito da relação entre cinema e história. A leitura que a cinematografia faz a respeito da história traz, para o historiador as dificuldades de sua própria interpretação do passado. De acordo com a experiência de vários cineastas contemporâneos, como o diretor e roteirista francês René Allio, que, graças às memórias da população e à tradição oral, o historiador pode trazer de volta à sociedade uma história de que tinha se perdido por meio da sétima arte.

Tratar do Cinema como objeto de pesquisa, é também trabalhar no tocante que a cinematografia é também uma arte. Quase todas as pessoas sabem que, se a arte causasse obrigatoriamente um choque ou alguma vibração, o mundo teria se modificado há muito tempo, devido a isso, pelo menos em seus grandes pioneiros do meio, pensavam que o cinema seria o responsável por impor e mostrar tal choque, de tocar as massas, tocar o povo.

Uma das grandes funções de utilizar a sétima arte como recurso e como um auxiliar pedagógico é a de buscar uma alternativa e não substituir as já existentes. Por isso, trazer uma ferramenta que muitas das vezes está ligada ao lazer, pode aproximar o discente a uma nova forma de relacionamento com o processo de aprendizagem. Pensando assim, há uma nova passagem para o conhecimento, além da pesquisa e do questionamento que os filmes trarão sobre os fatos e conjunturas históricas, ou seja, despertar uma maior reflexão sobre diferentes eventos que cercaram a humanidade bem como os acontecimentos contemporâneos, visto que uma das funções do cinema é representar a realidade. 


\section{MÉTODOS E PROCEDIMENTOS}

Para essa análise foram utilizados métodos com fundamento teórico, embasados em obras que tratam desses mesmos temas, como a junção de História e Cinema, quais os benefícios em construir e embasar opiniões pelos filmes, além de motivar e estimular a diversidade e pluralidade de inúmeras versões sobre o mesmo acontecimento histórico.

Além disso, na práxis foi utilizado o conhecimento empírico no filme em sala de aula, denominado de "O Retorno da Múmia" do produtor e diretor norte-americano Stephen Sommers, que possui alguns conceitos sobre o tema do Egito Antigo. No filme foram trabalhados alguns pontos sobre os Egípcios e, aliado ao longa-metragem, foi feita uma aula expositiva com a apresentação de slides para que pudéssemos trabalhar a fixação desses conteúdos que englobam o povo que viveu ao norte da atual África, como tópicos relacionados à fé, às crenças, sobre o processo de mumificação junto da crença na vida após a morte, onde o corpo precisava ser mantido para que houvesse onde a alma pudesse utilizar como morada na próxima vida.

A experiência com os alunos foi de grande sucesso, tendo em vista que, após a rodagem do filme, foi possível perceber uma maior interação dos discentes quanto ao tema, além de notar que, quando o tema foi retomado, houve uma maior recordação sobre os significados, já que os estudantes lembravam com mais afinco a respeito do tema trabalhado tanto no filme quanto na aula expositiva. Portanto, a junção dessas duas formas de transmissão de conteúdo trazem muitos benefícios para a aprendizagem.

Trazer filmes aos alunos, além de possibilitar o entendimento de conteúdos específicos, consegue trazer também a conscientização de que toda história é História.

Assim como todo produto cultural, toda ação política, toda indústria, todo filme tem uma história que é História, com sua rede de relações pessoais, seu estatuto dos objetos e dos homens, onde os privilégios e trabalhos pesados, hierarquias e honras encontram-se regulamentados, os lucros da glória e os do dinheiro são aqui regulamentados com a precisão que seguem os ritos de uma carta feudal: guerra ou guerrilha entre atores, diretores, técnicos, produtores, que é mais cruel à medida que, sob o estande da Arte, da Liberdade, e na promiscuidade de uma aventura comum, não existe empreendimento industrial, militar, político ou religioso que conheça diferença tão intolerável entre o brilho e a fortuna de uns e a obscura miséria dos outros artesãos da obra. (FERRO, 1992, p.17).

\section{DISCUSSÃO}

É possível avaliar algumas dificuldades enfrentadas para a realização dessa pesquisa, considerando as complicações vividas pelos 
professores para utilizar de tecnologias que possuem a finalidade de transmitir conteúdos cinematográficos, como, por exemplo, a falta de estrutura. Muitas salas não possuem retro projetor, não possuem o painel para exibição, ou seja, muitas vezes falta estrutura para realização dessas atividades. Por vezes devido à falta de investimento voltado para esse tipo de atividade fica impossível a realização desse tipo de projeto. Mas também, além da falta de escolas preparadas estruturalmente, o que pode ser detectado é a falta de cuidado com os investimentos já feitos, tendo assim dificuldade com a preservação dos materiais utilizados para a projeção dos filmes e dos conteúdos. Por isso, em inúmeras vezes não é possível aliar esses projetos cinéfilos ao dia-a-dia dos discentes, impossibilitando assim que os alunos consigam um maior entendimento e compreensão sobre aspectos de conteúdos específicos trabalhados em sala de aula.

Além disso, é possível trazer para o plano das ideias a dificuldade de inserção desse tipo de tecnologia dentro das escolas, muitas vezes devido à preferência de metodologias antigas de ensino, as quais os professores estão mais habituados e possuem um maior controle e manuseio. Além de pensar por esse lado, é possível salientar também que o professor não possui, da mesma maneira que não possui com outras artes como a música, um referencial de filmes de qualidade que podem ser utilizados, não detém um conhecimento sobre autores e diretores de cinema, muito menos uma orientação de certa forma didática para que os habilitem na utilização desse recurso, dessa ferramenta de uma forma mais proveitosa.

Há entre alguns professores certa resistência na hora de aplicar algum filme na sala de aula, pois muitas vezes recebem um julgamento de outros docentes, que explanam que seus colegas utilizam da sétima arte para poderem "enrolar" suas aulas, sendo assim muitas vezes visto de forma negativa perante olhares de outros profissionais.

É importante notar que trazer esse tipo de conteúdo para dentro da sala de aula só se faz positivo se usado de forma adequada, tendo em vista a ótima ferramenta de auxílio da aprendizagem que são os filmes. Trabalhar com uma peça que possui uma ligação com fatos históricos já que pode reproduzi-los como forma de um espetáculo, chamando assim a atenção dos espectadores para que os mesmos possam entender como a disciplina História estuda determinados fatos, é de grande ajuda para que possa haver uma melhor absorção do conteúdo.

Analisando agora o lado do discente, é necessário que haja uma maior preparação dos agentes da educação para que possam explicar aos alunos a importância de trabalhar determinados conteúdos em formato de filme, tirando da cabeça deles que quando se passa um filme, a aula é "livre", e que a mesma não é importante. Deve-se expressar aos alunos o grande aliado 
que eles detêm que é a cinematografia para que eles consigam enxergar uma nova perspectiva sobre os conteúdos aprendidos em sala de aula.

Ademais, é extremamente conveniente que haja uma adesão de todas as partes envolvidas no processo de aprendizagem escolar para que aconteça um maior engajamento no processo de aliar conteúdos passados em apostilas com conteúdos demonstrados, de certa forma prática, em filmes, documentários, entre outros. A resolução dos problemas supracitados pode enfim trazer benefícios na aprendizagem tanto individual, falando não só dos alunos por meio do conhecimento, mas também do coletivo envolvido no processo de aprendizagem, como os professores, coordenadores, diretores e todos os agentes ligados de forma direta à educação.

\begin{abstract}
É a ação do sujeito sobre o objeto, isolando partes, produzindo novas combinações, que produz o conhecimento. Os filmes, históricos ou não, seguem o mesmo padrão. Pode-se produzir o novo a partir de novos enfoques, para isso é necessário criar condições para que o aluno adquira os instrumentos conceituais que lhe permitam decodificar ideias já existentes e produzir novas. Aí está o papel, a ação do professor como agente desta transformação, desta nova educação histórica. (BÍCEGO, 2004, p. 41).
\end{abstract}

Quando se toca em um tema que não é sempre bem compreendido por todos, como a utilização de recursos áudio visual nas escolas, faz-se necessário entender que apenas incorporar a prática do vídeo e do cinema nas escolas não trará uma garantia de sucesso para os docentes e para uma melhora no conteúdo, pois existem meandros que fazem essa nova tecnologia funcionar, portanto, ou esse método é aceito, essa nova ferramenta de auxílio ao professor com toda a sua capacidade de inovação, assumindo, assim, uma grande transformação de todo um sistema educativo, ou não se submete a essa nova tecnologia, apenas usando delas suas vantagens que são inovadoras, mas apenas a serviço da velha e antiga pedagogia.

\title{
5. RESULTADOS
}

Durante a experiência vivenciada em sala de aula, foi possível notar que a abordagem de determinados conteúdos foi mais proveitosa por parte dos discentes, haja vista que eles interagiram de uma melhor forma com os conceitos trabalhados durante o filme, fazendo assim com que eles entendessem de uma maneira mais abrangente tudo que foi trabalhado na aula expositiva, melhorando até a participação individual de cada um.

É importante observar que após a visualização do filme, foi gerado um debate sobre os pontos importantes do longa-metragem e, com a participação dos alunos, pontos relevantes do filme foram levantados, pensamentos acabaram se complementando, fazendo com o que outros alunos aprendessem ouvindo a opinião do colega, e, mais que os discentes, os

LIPI FILHO, Luiz Marcelo; VILLELA, Vanessa Moscardini de Oliveira Junqueira; 
professores também puderam aprender ao ouvirem sobre lados que não haviam imaginado antes.

Pensando além do resultado específico da atividade, após passar o filme e ter trabalhado pontos que estimulassem a reflexão feita pelos alunos por meio da aula expositiva, debate, entre outros, houve uma grande adesão por parte dos discentes para que a prática fosse repetida em outras oportunidades e em outros temas que são tratados durante o ano letivo e, talvez, isso tenha sido uma das coisas que mais chamaram atenção, pois mesmo que a transmissão do longa-metragem e das atividades tenham sido meticulosamente pensadas, sempre há um medo do resultado, se o mesmo será realmente positivo e se terá o sucesso esperado. Por isso, após o término de todo o processo, quando os resultados positivos foram alcançados, a satisfação de ter feito algo diferente para os alunos, algo que saísse da rotina das aulas expositivas que muitas vezes são cansativas e não consegue fazer o discente manter a atenção na aula. Essa forma de pensar o trabalho em aula busca, pensar e planejar aulas diferentes do padrão pedagógico.

\section{CONSIDERAÇÕES FINAIS}

Alguns caminhos podem ser seguidos a fim de tornar mais aplicável a ideia de utilizar da sétima arte dentro da sala de aula. Um desses meandros pode ser a Universidade. Poucas Universidades utilizam na formação de seus historiadores um modelo que abra espaço para a tecnologia do cinema. São poucos os cursos que dão uma abertura maior para que possa ocorrer algum tipo de análise do cinema, até mesmo são poucos os professores que pontuam suas aulas, ou analisam determinados fatores por meio da cinematografia. Portanto, começar por aí pode ser um caminho bastante interessante. Quando se dá início a esse tipo de trabalho, é interessante que se inicie dentro da sala de aula do curso de História uma discussão de como pode ser aplicado, quais são as maneiras que seriam mais proveitosas, o que pode ser determinante para fazer o aluno entender que não é para ter um momento de relaxamento e sim uma fonte diferente, outro ponto de vista, ou até uma forma diferente de ilustrar determinado fato. Portanto, existem alguns fatores que dificultam a utilização do cinema como recurso pedagógico, como a preparação dos professores em formação.

Uma forma interessante a ser trabalhada pelo professor com seus alunos é a que o primeiro passo é explicitando a motivação de passar aquele filme, com a explicação de seu contexto histórico, onde ele se encaixa e qual tipo de pensamento ele faz parte. Além de demonstrar a função de cada um dos personagens do filme por meio de uma prévia, para que possam aprender a olhar com uma visão crítica sobre o filme passado em sala de aula. Ao apresentar mais elementos aos alunos sobre a atividade, é plausível que haja 
uma maior participação e entendimento dos alunos, pois os mesmos conseguirão entender as motivações do docente em passar aquilo a eles e, é possível que os discentes possam compreender mais a respeito do fato histórico, não apenas se apegar à arte em movimento, não entender que a visão que foi passada no filme deve ser vista como uma verdade estabelecida e sim como mais uma no meio de tantas outras interpretações.

Deve sempre haver cautela com o conteúdo passado ao aluno. $O$ filme deve ser bem escolhido, a atividade proposta pelo professor deve ser bem elaborada, pois isso tudo fará parte de um entendimento maior sobre História, além de fazer parte da aprendizagem na hora de desenvolver a interpretação, levando em conta tudo que envolve a cinematografia. Por isso, a realização de todo o processo deve mostrar ao aluno que ele deve ser protagonista do próprio conhecimento. Esse também terá a oportunidade de desenvolver um raciocínio crítico, sendo capaz de refletir e criar uma argumentação lógica e bem trabalhada.

Por isso, é importante observar os mínimos detalhes, que muitas vezes passam despercebidos pelos professores, como o volume, o tamanho da tela, o conforto da cadeira, entre outros aspectos, para que não tenha dispersão por parte dos alunos. Sabendo disso, o ideal seria que todas as escolas possuíssem um ambiente apropriado para realização dessas atividades. Contudo, sabemos da dificuldade apresentada pelos colégios em ter um local adequado e estruturado para que o aluno tenha a melhor experiência cinematográfica. É de conhecimento dos profissionais da educação que grande parte das escolas não comporta esse tipo de estrutura e é função dos docentes pensar em alternativas para que as atividades de utilização de filmes como ferramenta de assimilação de conteúdos não deixem de acontecer por causa de problemas no ambiente escolar.

\footnotetext{
Certamente existem "furos" nos roteiros destes filmes, como também existem na montagem de documentários ou mesmo nos textos dos livros que tratam de temas históricos. O filme pouco diverge das outras formas de discursos sobre a História, dando a sua contribuição para a inteligibilidade dos fenômenos históricos e difusão dos conhecimentos sobre a História. Possui, pode-se dizer, uma virtude pedagógica. (BÍCEGO, 2004, p.57)
}

Cabe ao professor buscar sempre um equilíbrio nas propostas metodológicas, tais como: o uso de filmes, diálogos e debates, bem como a preparação de uma aula expositiva. A flexibilização do conhecimento histórico é um ideal a ser alcançado no processo de ensino e aprendizagem dentro dos diferentes temas apresentados no currículo de História e nas competências e habilidades desenvolvidas em um plano de aula.

Assim sendo, por mais que os filmes sirvam de alternativa ao ensino tradicional, como a aula expositiva, é importante ressaltar que a cinematografia não substitui a utilização das diferentes metodologias propostas 
pelos referenciais pedagógicos, sendo assim uma complementação dos mesmos.

\section{REFERÊNCIAS}

BíCEGO, Mariano Aparecido.História a 24 quadros: a história, o cinema e seu uso em sala de aula. Ed. e Gráfica São Luiz, 2004. São Sebastião do Paraíso.

FERRO, Marc.Cinema e História. Ed. Rio de Janeiro: Paz e Terra, 1992.

COSTA, Antonio. Compreender o cinema. Ed. Globo, 1987. Rio de Janeiro.

DELEUZE, Gilles.A imagem-tempo. Ed. Brasiliense SA,1990. São Paulo.

DAVID, Célia Maria. Mudanças e resistências que permeiam o processo ensino-aprendizagem em história: uma revisão historiográfica e pedagógica no ensino público fundamental de franca. Cap. 2, p. 55. Ed. Unesp - FDHSS, 2001. Franca. 


\section{ÍNDICE}

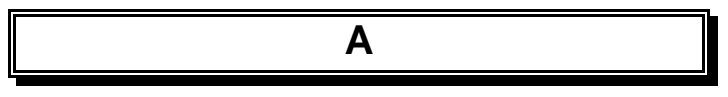

ALVES, Maria Sílvia Rodrigues, 19 ANDRADE, Giovanna de Souza, 159

\section{B}

BARBOSA, Natália Aparecida Silva, 19

BASTOS, Gene Emanuel Guedes, 84

\section{C}

CAROTA, Filipe Pimenta, 9

CARVALHO, Maximiliano de, 19

CLEMENTE, Guilherme Augusto

Bertelli Fernandes, 50, 141, 172

COELHO, Lucinda Maria de Fátima

Rodrigues, 159

CONTI, Carmen Lúcia Tozzi

Mendonça, 62

CRUZ, Pâmela Cian da, 125

\section{$\mathbf{F}$}

FADEL, Barbara, 211

FERNANDES, Ítalo, 125

\section{G}

GALERANI, Thiago da Silva, 117

GARCIA, Allyson da Silva, 109

GARCIA, Carlos Eduardo de

Campos, 159

GERA-BEIRO, Adriana Aparecida

Silvestre, 109

GONÇALVES, Gustavo Henrique, 50,

141,172

\section{I}

IVAN, Maria Eloísa de Souza, 84

$\mathbf{M}$

MALTA, Deise Aparecida Silva, 36 MARTINS, Murillo E. Ravagnani S, 191

MAZARON, André Eduardo Silveira, 211

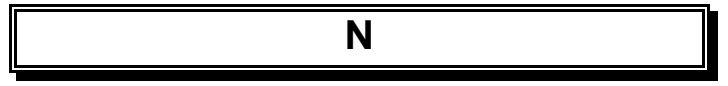

NASCIMENTO, Thaís Rodrigues de

Carvalho, 125

NICOLIELO, Maria Elisa, 36

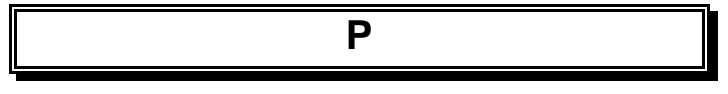

PEREIRA, Lais Lima, 71

\section{$\mathbf{R}$}

RODRIGUES, Lindsay Amanda, 84

\section{S}

SILVA, Fernanda Ferro da, 98

SILVA, Juliano Aparecido da, 98

SILVA, Katiucia, 62

SILVA, Messias Rogério Faria da, 109

SOMMERHALDER, Aline, 36

SPIRLANDELI, Ana Beatriz Sousa, 71

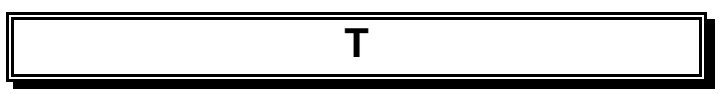

TAVARES, Graciele Faine, 50, 141, 172

\section{V}

VICENTE, Lucas Guimarães, 9

VIEL, Silvia Regina, 71 

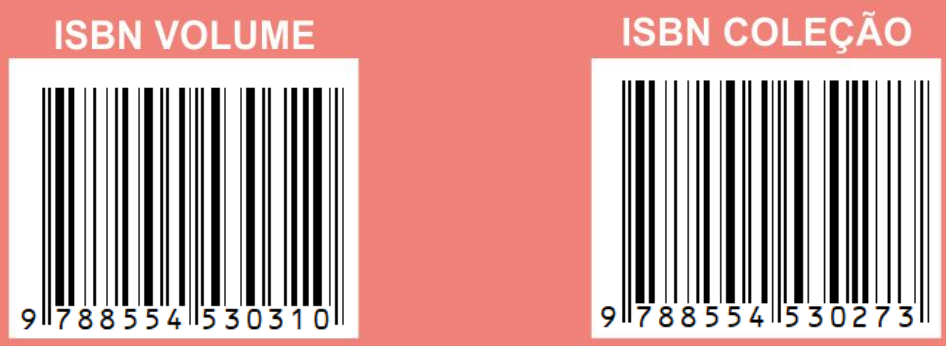

\section{8 | 163713.4688 unifacef.com.br | f}

\subsection{0} franca.unesp.br 